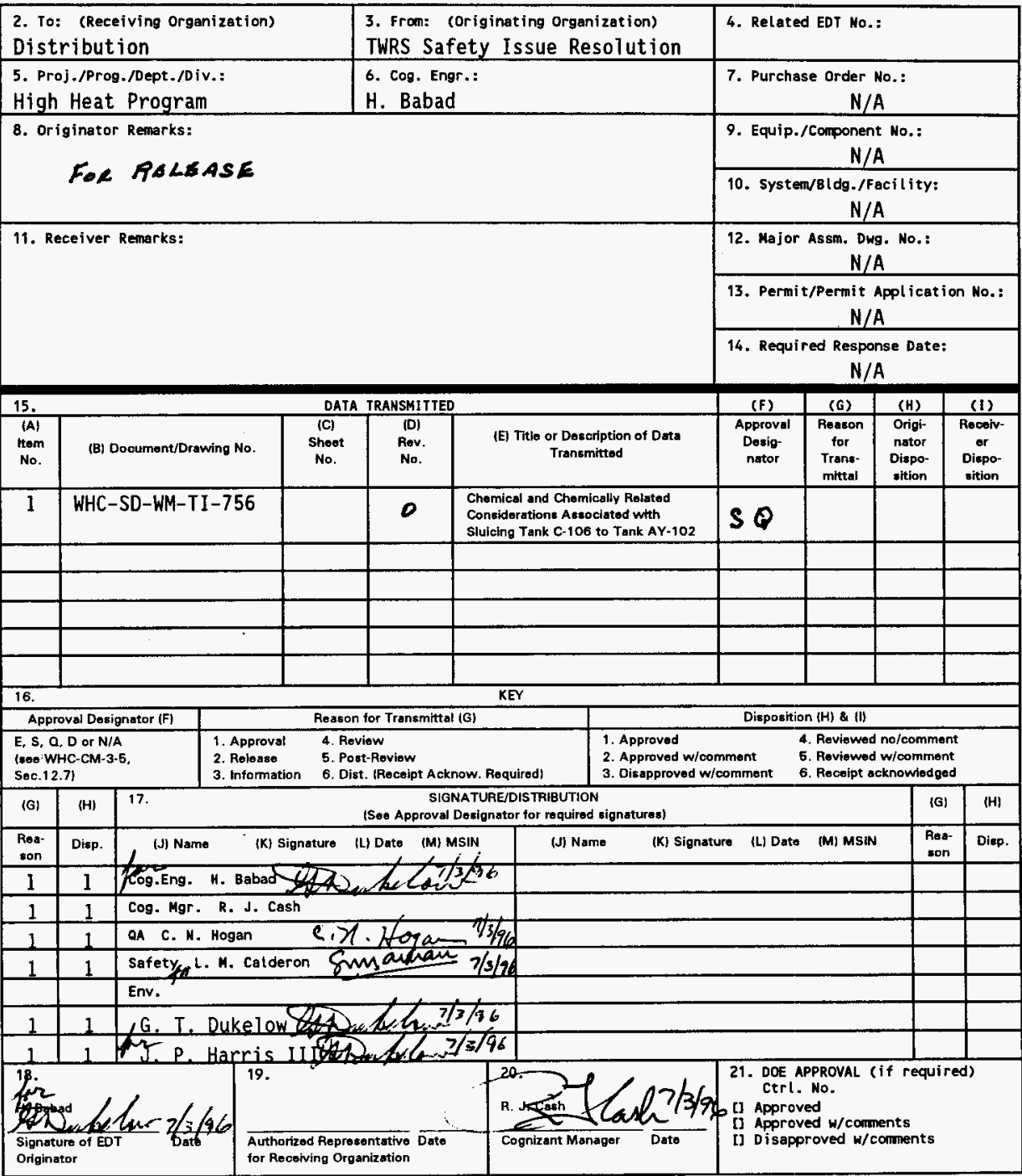

BD-7400-172-2 (04/94) GEF097 


\section{Chemical and Chemically-Related Considerations Associated with Sluicing Tank C-106 Waste to Tank AY-102}

H. Babad et al.

West inghouse Hanford Company, Richland, WA 99352

U.S. Department of Energy Contract DE-AC06-87RL10930
EDT/ECN: 613756
UC: 2030
Org Code: 79300
Charge Code: N2219
B\&R Code: EW3120071
Total Pages: 153

Key Words: High-Heat, Tank C-106, Sluicing, Waste Compatibility, Organic, and Waste Retrieval

Abstract: Abstract: New data on tank 241-C-106 were obtained from grab sampling and from compatibility testing of tank $\mathrm{C}-106$ and tank $\mathrm{AY}-102$ wastes. All chemistry-associated and other compatibility information compiled in this report strongly suggests that the sluicing of the contents of tank C-106, in accord with appropriate controls, will pose no unacceptable risk to workers, public safety, or the environment. In addition, it is expected that the sluicing operation will successfully resolve the High-Heat Safety Issue for tank C-106.

TRADEMARK DISCLAIMER. Reference herein to any specific comercial product, process, or service by trade name, trademark, manufacturer, or otherwise, does not necessarily constitute or imply its endorsement, recommendation, or favoring by the United States Government or any agency thereof or its contractors or subcontractors.

Printed in the United States of America. Io obtain copies of this document, contact: WHC/BCS Document Control Services, P.0. Box 1970. Mailstop H6-08, Richland WA 99352, Phone (509) 372-2420; Fax (509) 376-4989.
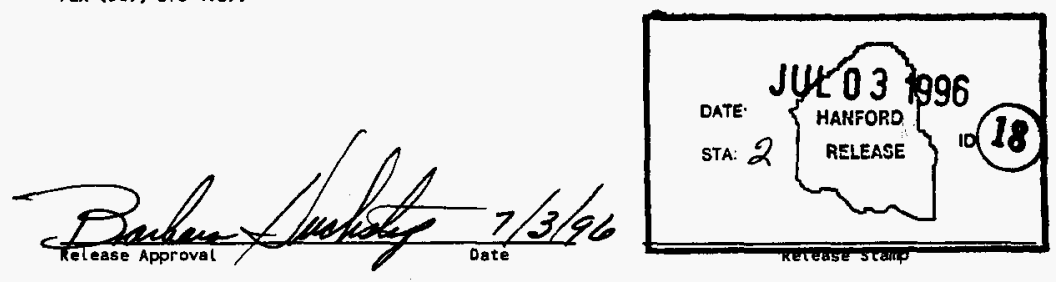

Approved for Public Release 


\section{RECORD OF REVISION}

(1) Document Number
WHC-SD-WM-TI-756

(2) Title

Chemical and Chemically Related Considerations Associated with Sluicing Tank C-106 to Tank AY-102

CHANGE CONTROL RECORD

\begin{tabular}{|l|l|}
\hline (3) Revision & (4) Description of Change - Replace, Add, and Delete Pages \\
\hline RE 0 & (7) $\begin{array}{l}\text { WHC-SD-WM-TI-756, Rev. O, EDT 613756, } \\
\text { July 3,1996 }\end{array}$ \\
\hline
\end{tabular}

Authorized for Release (5) Cog. Engr. (6) Cog. Mar. Date 


\title{
Chemical and Chemically-Related Issues Associated with Sluicing Tank C-106 Waste to Tank AY-102
}

H. Babad

L. M. Sasaki

R. D. Schreiber

L. A. Tusler

B. A. Crawford

R. A. Esch

T. J. Bander

Westinghouse Hanford Company

\author{
J. A. Campbell S. A. Bryan \\ G. M. Mong R. D. Scheele \\ Pacific Northwest National Laboratory \\ S. F. Agnew \\ Los Alamos National Laboratory \\ Date Published \\ July 1996
}

Prepared for the U.S. Department of Energy

Assistant Secretary for Environmental Management

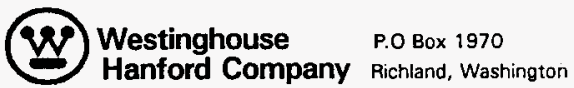

Manegement and Operations Contractor for the

U.S. Department of Energy under Contract DE-AC06-87RL10930

Approved for public release; distribution is unlimited 
CONTENTS

1.0 INTRODUCTION $\ldots \ldots \ldots \ldots \ldots \ldots \ldots \ldots \ldots \ldots \ldots \ldots \ldots \ldots \ldots \ldots \ldots$

2.0 A SUMMARY OF OVERSIGHT COMMITTEE CONCERNS $\ldots \ldots \ldots \ldots 2-1$

2.1 SPECIFIC CHEMICAL ISSUES $\ldots \ldots \ldots \ldots \ldots \ldots \ldots \ldots \ldots \ldots \ldots$

3.0 RELEVANT BACKGROUND INFORMATION $\ldots \ldots \ldots \ldots \ldots \ldots \ldots . . \ldots \ldots$

3.1 THE CHEMISTRY AND STRATIGRAPHY OF TANK C-106 $\ldots \ldots$ 3-1

3.2 SAMPLING ANALYSIS PLAN AND COMPATIBILITY

TEST PLAN SUMMARY $\ldots \ldots \ldots \ldots \ldots \ldots \ldots . \ldots \ldots$ 3-3

4.0 ORGANIC CHEMICAL CONCENTRATION CONCERNS $\ldots \ldots \ldots \ldots \ldots$. . . .

4.1 POTENTIAL FOR A PROPAGATING REACTION OF THE

RESIDUAL ORGANICS IN TANK C-106 AFTER DRYOUT . . . . . . 4-6

4.2 THE COMPOSITION OF THE OIL RELEASED BY

SLUDGE CENTRIFUGATION . . . . . . . . . . . . . . . . 4-7

4.2.1 Summary of Findings . . . . . . . . . . . . 4-7

4.2.2 Infrared Analysis of the Tank C-106 Oils . . . . . . . 4-8

4.2.3 Tank C-106 Species Identification and Quantitation . . . . . . 4-8

4.2.4 PNNL Analysis of Oil Extracted from C-106 Sludge . . . . . . 4 4-11

4.2.5 Comparison of Persulfate Quantitation

to TOC Furnace Results . . . . . . . . . . . . . . 4-11

4.2.6 Other Analyses of Tank C-106 Centrifuged

Sludge Oil (222-S Laboratory) . . . . . . . . . . . . . . . 4-12

4.2.7 Plutonium Analysis of Tank C-106 Centrifuge Oil . . . . . . . 4-13

4.2.8 Thermal Behavior of Concentrated Extracted

C-106 Centrifuge Oil . . . . . . . . . . . . . . . 4-13

4.2 .9 Organic Extraction Study $\ldots \ldots \ldots \ldots \ldots \ldots \ldots \ldots$. 4 .14

4.3 SAFETY IMPLICATIONS OF OIL RELEASED

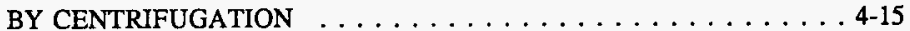

4.4 ACCIDENTAL OVERHEATING OF INITIAL C-106 SAMPLES $\ldots . .4$ 4-16

5.0 A PARTIAL REEXAMINATION OF WASTE COMPATIBILITY CONCERNS . . 5-1

5.1 COMPATIBILITY TESTING AND ORGANIC EXTRACTION . . . . . 5-1

5.1.1 Pretesting of Tank AY-102 Sludges for Organic

and Tank C-106 Sludges for Organic Separation . . . . . . . 5-1

5.1 .2 Supernate Characteristics . . . . . . . . . . . . 5-1

5.1.3 Tank C-106 Sludge Mixed with Neat AY-102 Supernate . . . . . 5-2

5.1.4 Settling Behavior of C-106 Sludges with AY-102 Supernates . . . 5-3

5.1 .6 Sedimentation Studies . . . . . . . . . . . . . . . 5-9 


\section{CONTENTS (Continued)}

5.2 THE POTENTIAL FOR CREATION OF A

GAS RELEASE EVENT IN TANK AY-102 DURING

OR AFTER SLUICING OF TANK C-106 . . . . . . . . . . 5-9

5.3 EFFECTS OF DEAGGLOMERATION

(TRANSFER LINE PLUGGING) $\ldots \ldots \ldots \ldots \ldots \ldots \ldots \ldots$. . . . . . . . . .

5.4 CONSEQUENCES OF "DISSOLUTION OF SALTS" . . . . . . . 5-10

5.5 WASTE COOLING AND SOLUBILITY CONSIDERATIONS $\ldots \ldots .5-11$

5.6 STORED ENERGY (Lattice Energy in Crystals) . . . . . . . . . 5-11

5.7 TOXIC GAS CONCERNS . . . . . . . . . . . . . 5-13

5.8 A SELECTIVE COMPARISON RECENT OF AY-102

RESULTS PAST SAMPLING EVENTS $\ldots \ldots \ldots \ldots \ldots \ldots \ldots$ 5-13

6.0 OBSERVED RADIOCESIUM AND STRONTIUM DISTRIBUTION $\ldots \ldots \ldots$ 6-1

6.1 C-106 SLUDGE GRAB SAMPLING RESULTS . . . . . . . . . 6-1

6.2 A SUMMARY OF STRONTIUM ANALYSIS RESULTS

FROM THE 1986 CORE SAMPLE . . . . . . . . . . . . 6-3

6.3 COMPARISON OF RECENT GRAB SAMPLES IN TANK C-106

WITH 1986 CORE SAMPLE AND THERMAL MODELING . . . . . 6-3

7.0 OBSERVED PLUTONIUM DISTRIBUTION $\ldots \ldots \ldots \ldots \ldots \ldots \ldots \ldots$ 7-1

8.0 SUMMARY OF FINDINGS $\ldots \ldots \ldots \ldots \ldots \ldots \ldots \ldots \ldots \ldots \ldots$

9.0 REFERENCES $\ldots \ldots \ldots \ldots \ldots \ldots \ldots \ldots \ldots \ldots \ldots \ldots \ldots \ldots \ldots \ldots$

\section{APPENDIXES}

A.1 CHEMISTRY-ORIENTED RCRS RESULTING FROM THE

CR-SUBTAP REVIEW OF RETRIEVAL OF TANK C-106 . . . . . . A.1-1

A.2 TABULATION OF AVAILABLE DRAFT LABCORE DATA ON WIDE-MOUTH-BOTTLE-BASED GRAB SAMPLES OBTAINED FROM TANK C-106 IN THE SPRING OF $1996 \ldots \ldots \ldots \ldots \ldots \ldots$. . . .1 . . .

A.3 DOSE MEASUREMENTS TAKEN DURING THE APRIL 19, 1986 CORE SAMPLING OF TANK $\mathrm{C}-106 \ldots \ldots \ldots \ldots \ldots \ldots$ A.3-1

A.4 WORST-CASE TOTAL ORGANIC CARBON MEASUREMENTS IN TANKS AY-102 AND C-106 . . . . . . . . . . . . . A.4-1

A.5 PRESENCE OF 2-ETHYLHEXYL-PHOSPHATE-RELATED MATERIALS IN OTHER TANKS $\ldots \ldots \ldots \ldots \ldots \ldots \ldots \ldots \ldots \ldots \ldots \ldots \ldots \ldots \ldots \ldots$ 


\section{LIST OF FIGURES}

3-1. Tank C-106 Grab Sample Activity $\ldots \ldots \ldots \ldots \ldots \ldots \ldots \ldots .6 \ldots$

5-1. Settling Rate: $\mathrm{C}-106$ in AY-102 Supernate $\ldots \ldots \ldots \ldots \ldots \ldots \ldots$ 5-7

5-2. Settling Rate: Mixed C-106/AY-102 in AY-102 Supernate $\ldots \ldots \ldots \ldots \ldots$ 5-7

\section{LIST OF TABLES}

3-1. C-106 Waste Type, Volume, and Depth $\ldots \ldots \ldots \ldots \ldots \ldots$ 3-1

3-2. Predicted C-106 Waste Chemistry Composition from HDW Estimate . . . . . . 3-4

4-1. Organic Related Analysis: Average DSC, TGA, and TOC Sludge Sample Results by Waste Depth $\ldots \ldots \ldots \ldots \ldots \ldots \ldots . . \ldots .2$

4-2. Average C-106 Sludge TOC and Oxalate Results by Waste Depth . . . . . . 4-4

4-3. Organic Related Analysis: Average DSC, TGA, and TOC Liquid Sample Results by Waste Depth . . . . . . . . . 4-5

4-4. Average TOC and Oxalate Results for C-106 Liquid Samples Analysis . . . . . . 4-6

4-5. Analysis of Sample 7-SA . . . . . . . . . . . . .

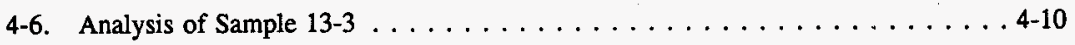

4-7. Oil Sample Average DSC, TGA, and TOC Results by Waste Depth $\ldots \ldots \ldots \ldots \ldots \ldots \ldots \ldots \ldots \ldots \ldots \ldots \ldots .12$

4-8. Oil Sample Average Pu Concentration $\ldots \ldots \ldots \ldots \ldots \ldots \ldots \ldots$ 4-13

4-9. DSC-Measured Enthalpies for the Tank C-106 Organic Sample . . . . . . . 4-14

4-10. Organic Sludge Washing $\ldots \ldots \ldots \ldots \ldots \ldots \ldots \ldots \ldots \ldots \ldots \ldots$

5-1. Sludge Mixed with AY-102 (2AY-96-5) $\ldots \ldots \ldots \ldots \ldots \ldots \ldots \ldots .2$

5-2. Characteristics of Sludge Components Before and After

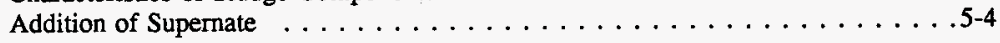


WHC-SD-WM-TI-756, Rev. 0

\section{LIST OF TABLES (Continued)}

5-3. Mixed Sludge Composition $\ldots \ldots \ldots \ldots \ldots \ldots \ldots \ldots \ldots$ 5-4

5-4. Settling Rate by Time Elapsed from Mixing $\ldots \ldots \ldots \ldots \ldots \ldots$ 5-5

5-5. Characteristics of Mixed Sludge Components

Before and After Supernate Addition $\ldots \ldots \ldots \ldots \ldots \ldots \ldots \ldots$ 5-8

5-6. Solids Before and After Settling $\ldots \ldots \ldots \ldots \ldots \ldots \ldots \ldots \ldots$ 5-9

6-1. Average Radio $\mathrm{Sr}$ and Cs Concentration Sludge Solids

Results From C-106 Sludge Grab Samples . . . . . . . . . . . . . . 66-2

6-2. Average Radio $\mathrm{Sr}$ and Cs Concentration Results

From C-106 Liquid Grab Samples . . . . . . . . . . . . . . 6-2

6-3. Sr-90 Results from 1986 Core Sampling of Tank C-106 . . . . . . . . . 6-3

6-4. Strontium and Cesium Concentrations in Samples . . . . . . . . . . 6-4

6-5. Strontium and Cesium Concentrations in Solids of Samples . . . . . . . 6-5

6-6. Heat Source Using Homogenized Concentrations $\ldots \ldots \ldots \ldots \ldots \ldots$. . . . . . .

7-1. Average C-106 Liquid Sample Plutonium Assay Results . . . . . . . . 7-2

7-2. Average C-106 Sludge Samples Plutonium Assay Results $\ldots \ldots \ldots$. . . . 7-3 


\section{LIST OF TERMS}

\begin{tabular}{|c|c|}
\hline $\begin{array}{l}\text { AR } \\
\text { AY-102 }\end{array}$ & $\begin{array}{l}\text { PUREX sludge waste from 244-AR Vault } \\
\text { tank 241-AY-102 }\end{array}$ \\
\hline BL & B Plant low-level complexant waste \\
\hline BNL & Brookhaven National Laboratory \\
\hline Btu/hr & British thermal units per hour \\
\hline C-103 & $\operatorname{tank} 241-\mathrm{C}-103$ \\
\hline C-106 & $\operatorname{tank} 241-\mathrm{C}-106$ \\
\hline $\mathrm{cm}$ & centimeters \\
\hline $\mathrm{cm} / \mathrm{min}$ & centimeters per minute \\
\hline CR-SubTAP & Chemical Reactions Subcommittee - Tech. Advis. Comm. to DOE-RL \\
\hline CRS & Chemical Reactions Sub-Panel \\
\hline CWP1 & PUREX coating waste \\
\hline DOE-RL & U. S. Department of Energy - Richland Operations Office \\
\hline DQO & data quality objective \\
\hline DSC & differential scanning calorimetry \\
\hline DTA & differential thermal analysis \\
\hline FID & flame ionization detector \\
\hline FTIR & Fourier transform infrared \\
\hline$g / g$ & grams per gram \\
\hline $\mathrm{g} / \mathrm{kg}$ & grams per kilogram \\
\hline $\mathrm{g} / \mathrm{L}$ & grams per milliliter \\
\hline $\mathrm{g} / \mathrm{mol}$ & gram-moles \\
\hline GC/MS & gas chromatography/mass spectrometry \\
\hline GRE & gas release event \\
\hline HDW & Hanford defense waste \\
\hline in. & inches \\
\hline IR & infrared \\
\hline $\mathrm{J} / \mathrm{g}$ & joules per gram \\
\hline $\mathrm{kcal} / \mathrm{mol}$ & kilocalories per mole \\
\hline kgal & kilogallons \\
\hline $\mathrm{kL}$ & kiloliters \\
\hline $\mathrm{mg}$ & milligrams \\
\hline $\mathrm{mg} \mathrm{C} / \mathrm{g}$ & milligrams carbon per gram \\
\hline $\mathrm{mg} / \mathrm{g}$ & milligrams per gram \\
\hline $\mathrm{mg} / \mathrm{L}$ & milligrams per liter \\
\hline $\mathrm{mg} / \mathrm{mL}$ & milligrams per milliliter \\
\hline $\mathrm{mL} / \mathrm{min}$ & milliliters per minute \\
\hline $\mathrm{mL}$ & milliliter \\
\hline $\mathrm{mol} / \mathrm{kg}$ & moles per kilogram \\
\hline $\mathrm{mol} / \mathrm{L}$ & moles per liter \\
\hline mrem & millirem \\
\hline
\end{tabular}




\section{LIST OF TERMS (Continued)}

$\begin{array}{ll}\text { nCi } & \text { nanocuries } \\ \text { nCi/g } & \text { nanocuries per gram } \\ \text { PNNL } & \text { Pacific Northwest National Laboratory } \\ \text { PUREX } & \text { plutonium-uranium extraction } \\ \text { RCR } & \text { review comment record } \\ \text { SpG } & \text { specific gravity } \\ \text { SY-102 } & \text { tank 241-SY-102 } \\ \text { TAP } & \text { Tanks Advisory Panel } \\ \text { TBP } & \text { tributyl phosphate (low-level non-TRU liquid waste) } \\ \text { TGA } & \text { thermogravimetric analysis } \\ \text { TOC } & \text { total organic carbon } \\ \text { TRU } & \text { transuranic } \\ \text { UR } & \text { Uranium Recovery } \\ \text { vol\% } & \text { volume percent } \\ \text { WHC } & \text { Westinghouse Hanford Company } \\ \text { wt\% } & \text { weight percent } \\ \mathrm{XRF} & \text { X-ray fluorescence } \\ \mu \mathrm{Ci} / \mathrm{g} & \text { microcuries per gram } \\ \mu \mathrm{Ci} / \mathrm{mL} & \text { microcuries per milliliter } \\ \mu \mathrm{g} \mathrm{C} / \mathrm{g} & \text { micrograms carbon per gram } \\ \mu \mathrm{g} / \mathrm{g} & \text { micrograms per gram } \\ \mu \mathrm{g} / \mathrm{kg} & \text { micrograms per kilogram } \\ \mu \mathrm{g} / \mathrm{mL} & \text { micrograms per milliliter } \\ \mu \mathrm{L} & \text { microliters }\end{array}$




\section{CHEMICAL AND CHEMICALLY-RELATED ISSUES ASSOCIATED WITH SLUICING TANK C-106 WASTE TO TANK AY-102 ${ }^{1}$}

\subsection{INTRODUCTION}

The purpose of this document is to provide additional information to Westinghouse Hanford Company (WHC) staff and to members of the Chemical Reactions Sub-Panel (CRS) of the Tanks Advisory Panel (TAP) that can be used to evaluate the safety of the transfer of high-heat solids from tank 241-C-106 (C-106) to tank 241-AY-102 (AY-102). This report supplements Safety Assessment for Tank 241-C-106 Waste Retrieval, Project W-320 (WHC 1996). Much of the information contained herein was obtained by running assays and compatibility tests on soft sludges recovered using a large-mouth bottle (on a string) sampler.

During its visits to the Hanford Site in November 1995 and January, February, and April 1996, the Chemical Reactions Subcommittee-Technical Advisory Committee (CR-SubTAP) to the U. S. Department of Energy Richland Operations Office (DOE-RL) reviewed the safety of the retrieval of the contents of tank $\mathrm{C}-106$, by past practices sluicing of the softer sludges contained in the tank, to double-shell tank AY-102. That review generated extensive comments (Hudson 1995), captured by WHC in review comment record (RCR) form, that addressed a variety of the Cr-SubTAP's concerns, many of which related to the chemical aspects of the waste. This report is written in response to the chemistry-oriented RCRs generated by the CR-SubTAP, and will also deal with a number of chemical concerns, generated by reviewers from the Brookhaven National Laboratory, that were appended to the CR-SubTAP's comments.

No attempt is made in this report to untangle to various RCR comments, some of which dealt with a variety of subjects; rather, the principal author has chosen to identify the underlying issues of concern to both the CR-SubTAP and the Brookhaven staff and to deal with them in an integrated fashion. Concordance of the information in this report to the RCR comments is provided (Section 2.0), as is the subset of RCRs assigned to or associated with items assigned for resolution to the principal author (see Appendix A.1).

Section 2.0 of this report contains a discussion that summarizes oversight committee concerns. Section 3.0 provides the reader with a limited amount of relevant background information on tank C-106 and on approaches to this most recent round of testing of waste samples retrieved from the tank in the Spring of 1996. Section 4.0 contains a discussion of concerns related to the presence of fuel-rich organic chemicals in tank C-106, including WHC's evaluation of the newly identified "sludge oil." Section 5.0 describes experimental

${ }^{1}$ For further information on these subjects, contact Dr. Harry Babad at Westinghouse Hanford Company, Richland, Washington, (509) 373-2897. 
work with actual $\mathrm{AY}-102$ and $\mathrm{C}-106$ samples; the work was aimed at assisting an engineering evaluation of lingering waste compatibility concerns. Section 6.0 provides, as input to C-106 thermal characterization modeling, added waste specific information on the observed radio-strontium and cesium distribution. Section 7.0 provides information on the observed plutonium distribution in the recent sludge samples. This information will provide some depth-related input on Pu concentrations for nuclear criticality analysis of tanks C-106 and AY-102. Section 8.0 provides a brief summary/conclusions section, and document references are found in Section 9.0.

Appendices included in this report contain: a listing of chemistry-oriented RCRs resulting from the CR-SubTAP review of retrieval of tank C-106 (Appendix A.1); a tabulation of available draft LABCORE data on the recent wide-mouth bottle-based grab samples obtained from tank C-106 in the Spring of 1996 (Appendix A.2); a summary of dose measurements taken during the April 19, 1986 core sampling of tank C-106 that supports thermal modeling (Appendix A.3); a brief discussion of inconsistent total organic carbon (TOC) data and the worst-case total organic carbon measurements in tanks AY-102 and C-106 as reported by Castaing (1995) (Appendix A.4). Finally, a brief discussion of the presence of 2-ethylhexyl phosphate-related materials in tank 241-C-103 (C-103) is provided (Appendix A.5). 


\subsection{A SUMMARY OF OVERSIGHT COMMITTEE CONCERNS}

\subsection{SPECIFIC CHEMICAL ISSUES (RCR Comments 8, 9, 21, 28, and 34)}

The CR-SubTAP was concerned with the following specific areas associated with the organic chemistry of tank C-106. Where appropriate, in the body of this document, cross references will be provided to CR-SubTAP comments and to the data-containing sections of this document.

Potential for a propagating reaction of the residual organies in tank C-106 after dryout. A focus of the CR-SubTAP's concerns was the "evaluation of hazard (e.g., waste dryout and overheating) consequences resulting from sluicing shutdown, or duration of shutdown, on C-106 waste. Appendix A.1, RCR 8 discusses possible consequences and behavior of waste remaining in C-106 after sluicing is completed; e.g., waste dryout and overheating (see Appendix A.1, RCRs 8 and 9). A related concern is the possibility of exceeding tank temperature limits (in the absence of water addition) due to hardpan left in C-106 after sluicing (see Appendix A.1, RCR 34)." Questions that result from this concern include:

Is tank C-106 an organic complexant-rich tank?

- Will any \{significant\} organic present transfer to AY-102 during sluicing?

The organics present in tank C-106 are low in energy and therefore will provide neither significant sources of carbon-hydrogen bonds (gas release event [GRE]-related issue) nor fuel (organic safety concern) to tank AY-102. (See Section 4.0)

- Will sufficient residual organics remain in the tank to pose a hazard from condensed phase propagation reactions when ventilation is stopped (and the tank heats and dries out) in tank C-106 after sluicing? (see Appendix A.1, RCR 33)

The organics present in tank C-106 are low in energy and therefore will not provide significant quantities of fuel (organic safety concern) upon drying out the tank after sluicing is complete. (See Section 4.0)

- Conflicting Chemical TOC Data (Part of RCR Comment 28).

The data provided in Section 4.0 support the information used in safety analysis for the retrieval process. No support was found for the credibility of higher TOC values that were of concern to the CR-SubTAP. In addition, the energetics associated with the TOC measurements strongly suggest that any complexants added to tank C-106 have aged to less-reactive sodium oxalate. 
Strontium Distribution. (Tank Safety-Related Heat Load Concerns) (Related to Appendix A.1, RCRs 8, 9, 32, 33, and 34)

- Where is the heat source? Does WHC have reliable information about its magnitude? What is the evidence that significant heat is not generated in the hardpan? Are temperature records available for the period before the addition of Sr? The CR-SubTAP suggests examination of existing data for more detailed answers. (RCR 32 and 33)

The strontium and cesium assays (Section 6.0) reported in this document support the hypothesis that significant quantities of heat-generating materials are found in the soft sludge layer. Although sampling limitations precluded providing a definitive answer to the question of whether significant heat is generated in the hardpan, updated modeling efforts conclude that heat so generated would not pose a safety problem after the sluicing of soft materials from tank C-106.

Plutonium Distribution Issues. (RCR Comments 21, 25, and 38)

- $\quad$ Are there any transuranic (TRU)-related waste compatibility issues associated with transfer of wastes from tank C-106 to tank AY-102?

No criticality-related concerns were identified by the work reported in Section 7.0 of this report. In evaluating the potential for nuclear criticality related to the transfer of the contents of tank C-106 to tank AY-102, the stability constants for plutonium oxyhydroxide precluded significant solubilization of plutonium by the small amounts of complexants in tank AY-102 (Waltar 1996).

CR-SubTAP was concerned with whether there is a criticality issue. "We strongly suggest a definitive criticality analysis be performed for this specific project before retrieval begins (RCR 25). What are the consequences with respect to criticality in using a sluicing fluid which contains complexants capable of segregating plutonium?" That task is complete (e.g., Waltar 1996).

Waste Compatibility Concerns. (RCR Comments 21, 22, 23, 35, 36, 37, 39, 40, 41, and 44 deal with some aspect of waste compatibility)

- What is the potential for creation of a gas release event (GRE) in tank AY-102 during or after sluicing tank C-106? (RCR Comments 21, 23, and 36)

Although compatibility tests made on combinations of C-106 sludge and 241-SY-102 (SY-102) sludge and supernatant fluids did not suggest any issues associated with GRE formations, all data presently available cannot preclude that such phenomena could occur. Therefore, the project will use a partial 
sluicing strategy, coupled with a detailed gas evolution and surface and sludge height measurement strategy (Barton 1996), to assure that a GRE condition cannot occur in tank SY-102.

- Are the chemistry and physics of the waste in tank C-106 similar to those known to lead to gas retention and/or potential for GRE events?

See Barton (1996).

CR-SubTAP Concerns with Waste Compatibility- and Operability-Related Issues. Concerns were repeatedly voiced by the CR-SubTAP on the behavior of solids in the C-106 and AY-102 system, resulting in a set of waste compatibility- and operability-related issues. These issues were itemized in the bullets above. The following sections provide more detailed listings of the CR-SubTAP concerns.

GRE Related Comments. "C-106/AY-102 waste compatibility." The primary concern is creating GRE conditions (RCR 21). Post-transfer "fluffing" of waste and its effect on waste behavior (e.g., gas retention) (RCR 23). Could there be a gas generation (release) problem? Unless safe upper limits for the volume of retained gas can be demonstrated. we suggest continuous monitoring of flammable gas concentration in the dome spaces of both $\mathrm{C}-106$ and AY-102 (consistent with flammable gas controls) before, during, and after retrieval (RCR 36)."

- Are there any other waste compatibility issues associated with transfer of wastes from C-106 to AY-102 (e.g., RCR Comment 41)?

Compatibility tests made on combinations of C-106 sludge and SY-102 sludge and supernatant fluids did not suggest any "other" compatibility issues associated with transfer of wastes from tank C-106 to tank AY-102 (See Section 5.0).

- Deagglomeration - RCR Comment 22

Compatibility tests made on combinations of C-106 sludge and SY-102 sludge and supernatant fluids did not suggest any deagglomeration-related issues associated with transfer of wastes from tank C-106 to tank AY-102 (See Sections 5.1 and 5.3).

- Transfer Line Plugging and Waste Compatibility - RCR Comment 39

Compatibility tests made on combinations of C-106 sludge and SY-102 sludge and supernatant fluids did not suggest any line plugging-related issues associated with transfer of wastes from tank C-106 to tank AY-102 (See Section 5.3). 
- Waste Cooling and Solubility Considerations - RCR Comments 40 and $\mathbf{4 4}$

Consideration of the chemical characteristics of C-106 sludge and SY-102 sludge and supernatant fluids did not suggest any waste cooling or solubilityrelated issues associated with transfer of wastes from tank C-106 to tank AY-102 (See Section 5.4, 5.5).

- $\quad$ Stored Energy (Lattice Energy in Crystals) - RCR Comment 35

Evaluation of the chemistry and physics of the waste materials in tank C-106 did not suggest any possibility of problems related to stored lattice energy in waste crystals (see Section 5.6).

- Consequences of "Dissolution of Salts" ... Gas Evolution - RCR Comment 37

Sluicing with dilute liquids will not cause release of water-soluble gases. Although ammonia has been found in the headspaces of most tanks, conditions for its storage and spontaneous release during sluicing in tank C-106 appear unlikely. Furthermore, this document reports that the nature of the solids in tanks C-106 and AY-102 poses no compatibility concerns related to "Dissolution of Salts," because there are no significant amounts of water-soluble salts (the tanks are undersaturated in sodium nitrate and nitrite) present in either of these tanks (See Section 5.4).

Concerns were also voiced by the CR-SubTAP on the behavior of solids in the C-106 and AY-102 system resulting in a set of waste compatibility- and operability-related issues. This concern is dealt with above.

Waste Solubility/Dissolution Effects. "What is the plan to preclude potential precipitation during transfer and getting pipes plugged? Related questions: Will there be a plugging problem during start up or shut down? How would pipe blockage be addressed? How does the plan to avoid pipe plugging compare with those of past practice (both successful and unsuccessful)? We suggest describing expected gas release, particle size distribution, etc. in the transfer line, together with bounds for flow rate, particle size, and solids loading, entrained or released gas, etc. (to avoid pipe blockage or damage) and associated controls. If pipe blockage cannot be ruled out, we suggest including a description of contingency plans (RCR 39)."

"What are the consequences involved in the dissolution of precipitated salts in the sludge? (RCR 37)"

"What problems will emerge when the saturated sluicing solution, produced in the sluicing operation, drops in temperature in the transfer lines? Answer given at the CR-SubTAP meeting: "Dilute solutions based on using buffered water should not create saturated sluicing solutions" and "The analysis determined that the temperature change during transfer is less 
than $2{ }^{\circ} \mathrm{C}$, which is minimum in respect to the unsaturated region of the waste during transfer." We suggest arguments leading to these conclusions be included (R.CR 40)."

Specifics Needed On Waste Compatibility Tests. "What tests have been done to demonstrate compatibility between the sluicing fluid and the $\mathrm{C}-106$ waste? (What will be done to ensure compatibility?) While specific actions were not agreed upon, the mixing of actual waste samples would appear to give the most reliable answer. We request presentation of a detailed plan, including important factors and specific steps, to determine waste compatibility. (RCR 41)"

Compatibility tests were made on C-106 and AY-102 wastes and are reported herein.

Solution Concentration Effects. "Is the assumption that dilution can be used to prevent line plugging practical when considered in the light of the mass of soluble precipitated salts in the sludge? Is there a significant amount of potential soluble material than can dissolve and re-precipitate? Whether the answer is yes or no, we believe the answer should be given in the document (RCR 44)."

As was stated earlier, the wastes were undersaturated with respect to most salts.

Stored Energy (As Superheated Steam). "Is there any stored energy in the waste that may be violently released during sluicing? WHC placed major emphasis at CR-SubTAP presentations on the fact that such behavior had not been observed in tanks containing similar high-heat waste. We believe the answer must be based on data from $\mathrm{C}-106$. We therefore suggest re-examination of existing data (including original data references) to attempt reconciliation of inconsistencies and determine whether superheated regions can be ruled out. If superheated regions cannot be ruled out, we suggest considering the potential effects of steam flashing. (RCR 34)"

Modeling suggests that by keeping the liquid level during sluicing level with the waste surface, superheated (steam generating) conditions will be avoided. Such controls will become part of operating conditions for sluicing $\mathrm{C}-106$.

Waste Settling/Deagglomeration Related Concerns. "Possible de-agglomeration of waste particles and its effect on settling. This concerns both clarification of sluicing fluid and the potential for gas retention (RCR 22)."

Compatibility testing demọnstrated little deagglomeration.

Toxic Gas Concerns. "How much and what kinds of toxic gas will be released? We suggest inclusion of a detailed description of the potential source term and corresponding health and safety controls (Part of RCR 37)." 
This document provides detailed discussions of many, but not all, of the aspects of chemistry that were of concern to the CR-SubTAP and provides information for use by WHC process engineers and/or modelers to evaluate the remaining concerns.

No sampling of the riser exhaust line for ammonia was possible in the time available for this study. However, plans are being implemented to get baseline headspace concentration data for tanks C-106 and AY-102 prior to starting sluicing. This data, coupled with gas monitoring and establishment of gas concentration controls during sluicing (with cool dilute waste solution), should assure safety with respect to toxic gases. 


\subsection{RELEVANT BACKGROUND INFORMATION}

\subsection{THE CHEMISTRY AND STRATIGRAPHY OF TANK C-106 (Agnew 1995)}

Tank C-106 is a 2,000-kL (530-kgal) tank, and contains four identifiable major waste layers. The bottom layer consists of $102 \mathrm{~kL}$ ( $27 \mathrm{kgal}$ ) of uranium recovery (UR) waste. (Note that $47 \mathrm{~kL}(12.5 \mathrm{kgal})$ is needed to fill the tank's dished bottom, leaving only $13 \mathrm{~cm}(5 \mathrm{in}$.) of UR layer at the risers at the edge of the tank. The remaining $640 \mathrm{~kL}$ (170 kgal) of waste is high-heat, higher-plutonium-containing, soft sludge). NOTE: The observed plutonium concentration is still well below concentrations of criticality concern.

The numbers proposed in the Hanford defense waste (HDW) documentation differ somewhat from those reported in WHC sources. Although other values are used in a number of supporting documents, based on alternate interpretations of historic data (i.e., $91 \mathrm{~kL}$ [24 kgal] of hardpan, and $655 \mathrm{~kL}$ [173 kgal] of soft sludge for $12 \% / 88 \%$ split volumes, respectively, rather than the $25 \% / 75 \%$ given in the Agnew [1995] evaluation), this difference has no effect on the outcome of the studies reported in this document.

The waste contents are described in Table 3-1.

Table 3-1. C-106 Waste Type, Volume, and Depth. ${ }^{1}$ (Agnew 1995)

(2 Sheets)

\begin{tabular}{|c|c|c|}
\hline 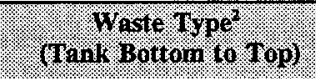 & Waste volime & 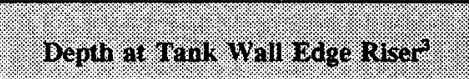 \\
\hline $\begin{array}{l}\mathrm{UR} \text { (from treated } \mathrm{BiPO}_{4} \\
\text { metal waste) }\end{array}$ & $27 \mathrm{kgal}$ & 5 in. $[\Sigma 27$ kgall $]$ \\
\hline $\begin{array}{l}\text { CWP1 (PUREX coating } \\
\text { waste) }\end{array}$ & $34 \mathrm{kgal}$ & 5 in. to 17 in. [ $\Sigma 61 \mathrm{kgal}]$ \\
\hline $\begin{array}{l}\text { AR (PUREX sludge from } \\
\text { 244-AR Vault - PUREX } \\
\text { sludge wash waste) }\end{array}$ & $64 \mathrm{kgal}$ & 17 in. to 40 in. [ $\Sigma 125 \mathrm{kgal}]$ \\
\hline $\begin{array}{l}\text { BL (B-Plant low-level } \\
\text { complexant waste) }\end{array}$ & $20 \mathrm{kgal}$ & 40 in. to 47 in. [ $\Sigma 145 \mathrm{kgal}]$ \\
\hline Unknown & $52 \mathrm{kgal}$ & $\begin{array}{l}47 \mathrm{in} \text {. to } 66 \mathrm{in} \text {; Assigned to } 26 \mathrm{AR} \text { and } \\
26 \mathrm{BL} \text { [ } 2197 \mathrm{kgal}]\end{array}$ \\
\hline
\end{tabular}


Table 3-1. C-106 Waste Type, Volume, and Depth. ${ }^{1}$ (Agnew 1995) (2 Sheets)

Notes:

The unknown layer is assigned to reflect a solids level adjustment from $540 \mathrm{~kL}$ (142 kgal) in 1978 (4th quarter) to $745 \mathrm{~kL}$ (197 kgal) in 1979 (1st quarter). Because there were no further solids-containing waste additions to explain this increase in solids, Agnew (1995) assumed that these solids actually derive from a combination of AR and BL, and assigned the unknown layer contents accordingly.

PUREX = plutonium-uranium extraction

'The methods used to get the estimates found in Tables 3-1 and 3-2 are found in Agnew (1995).

The four main waste types (UR, CWP1, AR, and BL) are listed in the order that they entered the tank. However, the unknown waste cannot be assumed to be a layer on the top of the waste; rather, it is the missing volume associated with the HDW transaction record for tank $\mathrm{C}-106$.

${ }^{3}$ Measured from bottom of tank wall.

The UR layer consists of additions of uranium recovery wastes (formally called tributyl phosphate [TBP] waste). However, it undoubtedly contains some unsluiced metal waste heel ("hardpan") as well.

The CWP1 layer consists of cladding waste additions from early PUREX operations accumulated through 1960 (2nd quarter).

The AR layer consists of solids that were transferred from AR Vault from 1967 to 1971. During this operation, PUREX sludge solids that were sluiced from A and AX farms were fed to AR Vault and allowed to sediment. The supernatant was transferred to tank C-106, allowed to clarify, and then transferred to tank C-105 for feed to cesium recovery. Low-Cs supernatants from tank C-105 were cycled to the AR Vault for caustic washing of sludges to leach as much $\mathrm{Cs}$ out as possible. These washings were cycled back to tank $\mathrm{C}-105$ through tank C-106.

The AR solids were then acid digested and the supernatant from that digestion was sent to B Plant for Sr removal. Any remnant solids were reneutralized and recycled through the strontium recovery process steps. The AR solids that accumulated in tank C-106 and other tanks were derived from peptized (non-sedimented) solids from all of these processing activities.

In 1974, as a result of an attempt to move some of the AR solids to other C Farm tanks by pumping, some AR solids from tank C-106 were moved to tank C-103. At that point, C-106 began receiving BL waste from B Plant, and the upper layers of the tank are due to these latter additions. The tank was declared inactive in early 1979. 
Once again, the unknown $200-\mathrm{kL}$ (52-kgal) layer is most likely simply unaccounted AR and BL solids; Agnew (1995) has assigned them as such in his inventory prediction. His Hanford Defined Waste layer compositions for these waste types are listed in Table 3-2.

The volume of the supernatant liquids in the tank varies according to the level of evaporation of that fluid. The volume has been estimated at about $120 \mathrm{~kL}(32 \mathrm{kgal})$.

\subsection{SAMPLING ANALYSIS PLAN AND COMPATIBILITY TEST PLAN SUMMARY}

The Tank 241-C-106 Grab Sampling and Analysis Plan (Schreiber 1996) identifies the overall characterization objectives for sample collection, laboratory analytical evaluation, and reporting requirements for the tank C-106 grab sample event. These requirements are consistent with the Data Quality Objectives for Tank Farms Waste Compatibility Program (Fowler 1995), the Tank Safety Screening Data Quality Objective (Dukelow et al. 1995), and Tank 241-C-106 Grab Sample - Technical Letter of Instruction (Cash and Babad 1996). The specific needs of this sampling event identified in the Sampling and Analysis Plan include:

- Verification that tank C-106 contains little or no TOC or has low energetics

- Spot checking of the radiocesium content in solution to verify dose estimates during retrieval

- Determination of ${ }^{90} \mathrm{Sr}$ and TRU content to demonstrate whether these chemical constituents are well represented in the tank's topmost solids layer.

The WHC 222-S Laboratory test plan, Sample Preparation of Tank 241-C-106 Samples and Testing for Compatibility with Tank 241-AY-102 Supernate (Crawford 1996), provides sample preparation methods for the non-routine analyses required by Schreiber (1996). The non-routine analysis guidance specified in Crawford (1996) includes the separation of the tank C-106 solid and liquid fractions, a solvent extraction test to remove organic material from the solids, centrifugation tests to evaluate ease of oil release from C-106 sludges, and compatibility mixing studies of tank C-106 sludge with tank AY-102 supernatant and sludge.

Figure 3-1 contains a cross sectional view of tank C-106 that provides a visual indication of the location of the samples that form the primary focus of this report. A total of $16 \mathrm{grab}$ samples were taken from tank C-106 in February and March 1996. Samples 6C-96-1 to 6C-96-4 were taken through riser 1 on February 8, samples 6C-96-5 to 6C-96-10 were taken through riser 1 on February 23, and samples $6 \mathrm{C}-96-11$ to $6 \mathrm{C}-96-16$ were taken through riser 7 on March 1. 
Table 3-2. Predicted C-106 Waste Chemistry Composition from HDW Estimate. ${ }^{1}$ (2 sheets)

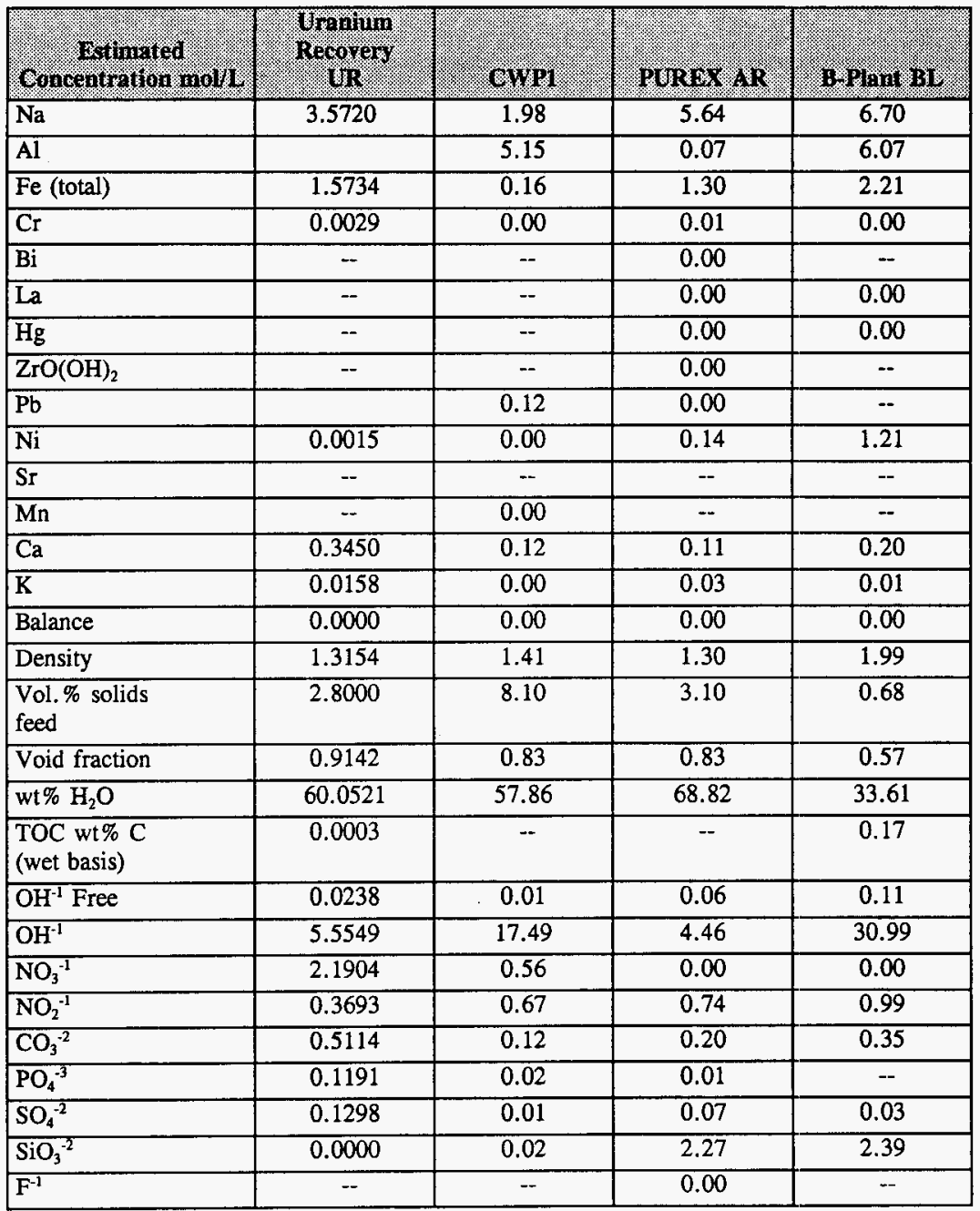


Table 3-2. Predicted C-106 Waste Chemistry Composition from HDW Estimate. ${ }^{1}$ (2 sheets)

\begin{tabular}{|c|c|c|c|c|}
\hline 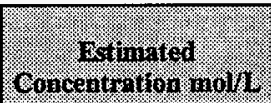 & 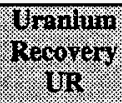 & (1) & prant & \% \\
\hline $\mathrm{Na}$ & 3.5720 & 1.98 & 5.64 & 6.70 \\
\hline $\mathrm{Cl}^{-1}$ & 0.0938 & 0.01 & 0.00 & -- \\
\hline $\begin{array}{l}\text { Citrate } \\
{\left[\mathrm{C}_{6} \mathrm{H}_{5} \mathrm{O}_{7}^{-3}\right]}\end{array}$ & - & -- & -- & 0.01 \\
\hline EDTA $^{4}$ & - & -- & -- & - \\
\hline HEDTA $^{-3}$ & -- & -- & - & -- \\
\hline Glycolate & -- & -- & - & 0.012 \\
\hline Acetate & -- & - & -- & -- \\
\hline Oxalate & - & -- & - & -- \\
\hline DBP & -- & $\cdots$ & -- & -- \\
\hline Butanol & -- & -- & - & - \\
\hline $\mathrm{NH}^{3}$ & 0.0009 & 0.00 & 0.22 & 0.09 \\
\hline $\mathrm{Fe}(\mathrm{CN})_{6}{ }^{-4}$ & $\cdots$ & -- & -- & -- \\
\hline $\mathrm{Pu}-239(\mathrm{nCi} / \mathrm{g})$ & 0.0032 & 0.58 & 7.27 & 2.61 \\
\hline $\mathrm{U}-238(\mathrm{~mol} / \mathrm{L})$ & 0.1397 & 0.10 & 0.00 & 0.56 \\
\hline $\mathrm{Cs}-137(\mathrm{Ci} / \mathrm{L})$ & 0.0013 & 0.00 & 0.23 & -- \\
\hline $\begin{array}{l}\mathrm{Sr}-90(\mathrm{Ci} / \mathrm{L}) \\
\text { decayed to } 1-1-94\end{array}$ & 0.0220 & 0.00 & 11.83 & 4.70 \\
\hline
\end{tabular}

Notes:

'The methods used to get the estimates found in Tables 3-1 and 3-2 are found in Agnew (1995).

- = No information provided by Agnew (1995). 


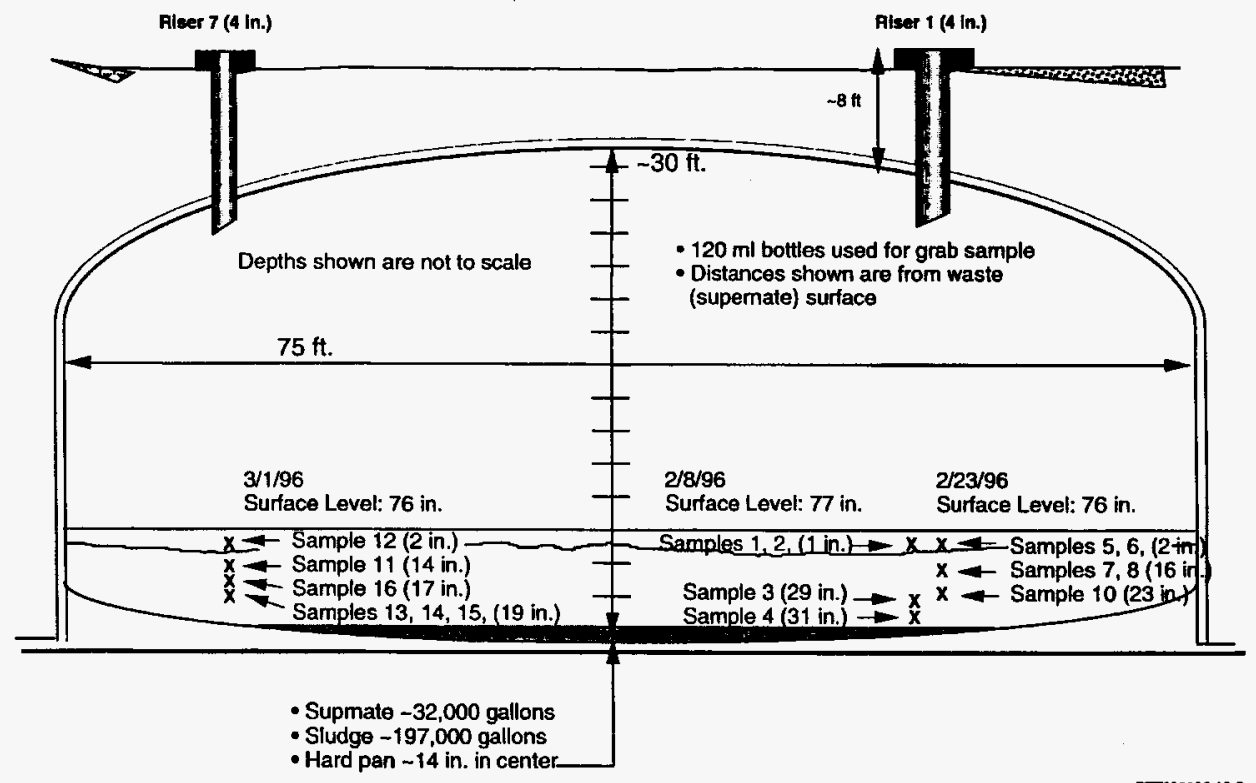




\subsection{ORGANIC CHEMICAL CONCENTRATION CONCERNS}

The CR-SubTAP expressed concern whether tank C-106 contained sufficient organics to pose a risk for propagation after retrieval of the soft suspendable solids, if the tank contents were allowed to dry out. The primary purpose of retrieving the waste from tank C-106 is to allow WHC to stop adding cooling water, with its concomitant requirement for active ventilation, to the tank. Cooling water addition poses the potential, in these single-shell tanks, that a loss of tank integrity could result in the fluid contents of the tank leaking to the surrounding soils. The addition of water does not in itself pose a potential for a loss of integrity. Although the potential is there whether or not water is added, the required continued addition of water can obviously result in greater consequences if a leak occurs. Such a leak is not unlikely, considering that 63 single-shell tanks have required saltwell pumping to reduce the drainable liquid inventory that could be drained to the soil.

The organic safety program considers a tank at risk from a propagating reaction if that tank contains 3\% or more TOC with an energy value of at least $480 \mathrm{~J} / \mathrm{g}$ (dry weight basis). The presence of water mitigates these conditions somewhat, but cannot be relied upon relative to high-heat tank C-106. In addition, it is well documented that tanks containing significantly less organic $(0.8$ to $3 \%$ TOC), where the organic is associated with species that contain carbon-hydrogen and nitrogen-hydrogen bonds, generate hydrogen gas at rates considerably more rapid than the rate of radiolysis of water. This production of hydrogen, coupled with inopportune physics, is the cause of a potential Flammable Gas safety issue. This safety issue is a subject of CR-SubTAP concern, and is dealt with in Section 5.2 of this report.

The Safety Screening data quality objective (DQO) (Dukelow et al. 1995) requires testing of tank samples for energetics as well as moisture content. If energetics of $480 \mathrm{~J} / \mathrm{g}$ (dry weight basis) are found, TOC analysis is required. Because of the interest in the risk from organics, TOC analysis was made part of the sampling and analysis plan (Schreiber 1996). A further modification to standard characterization practices was the addition to the sampling and analysis plan of a dewatering step to minimize analytical ambiguities and identify speciesspecific effects between the tank solids and the aqueous solutions that are part of the waste. Such a dewatering step would allow one to determine whether energetics in a waste sample were due to fuel-rich soluble organic complexants (which could be easily removed by sluicing), or whether they were associated with the solids. This question focuses on the broader issue of how completely the soft materials in tank C-106 could be sluiced, an issue dealt with in the Project W-320 Safety Assessment (WHC 1996).

Table 4-1 contains the results of differential scanning calorimetry (DSC), thermogravimetric analysis (TGA) and TOC analysis of the sludges obtained from C-106. Interpretation of the data is made a bit more complex than usual by the fact that the dewatering step required in the sampling and analysis plan added another unexpected complication to the analysis and interpretation process. 
Table 4-1. Organic Related Analysis: Average DSC, TGA, and TOC Sludge Sample Results by Waste Depth. ${ }^{7}$ (2 sheets)

\begin{tabular}{|c|c|c|c|c|c|c|c|}
\hline & \multicolumn{2}{|l|}{ Piser. I } & (2) & : & \multicolumn{3}{|c|}{ pesser? } \\
\hline $\begin{array}{l}0,6 \% \\
0 \%\end{array}$ & $\begin{array}{l}(104 \\
(10 \%\end{array}$ & $\begin{array}{l}10 \% \\
1 \% \% \\
6 \%\end{array}$ & $(1 \mathrm{ept}$ & Mample & ostor & $(1+\%)$ & $\frac{100}{10 \%}$ \\
\hline 110 & 8.28 & nr & $14-16$ & $\begin{array}{l}\text { Centrifuged } \\
\text { sludge }\end{array}$ & 71 & 9.03 & $\mathrm{nr}$ \\
\hline 0 & 31.1 & nr & & $\begin{array}{l}\text { Control } \\
\text { sample }\end{array}$ & 235 & 39.8 & nr \\
\hline 325 & 12.8 & 3.1 & & $\begin{array}{l}\text { Filtered, } \\
\text { centrifuged } \\
\text { sludge }\end{array}$ & 0 & 31.9 & 2.7 \\
\hline $\begin{array}{c}142^{2} \\
0^{3}\end{array}$ & $\begin{array}{l}52.9^{2} \\
57.9^{3}\end{array}$ & $\begin{array}{l}2.4^{5} \\
2.7^{6}\end{array}$ & $16-19$ & Raw sludge & $\begin{array}{l}127^{2} \\
446^{3}\end{array}$ & $\begin{array}{l}64.2^{2} \\
55.3^{3}\end{array}$ & $\begin{array}{l}8.1^{5} \\
6.5^{6}\end{array}$ \\
\hline 0 & 12.9 & $\mathrm{nr}$ & $19-23$ & $\begin{array}{l}\text { Centrifuged } \\
\text { sludge }\end{array}$ & 243 & 9.36 & $\mathrm{nr}$ \\
\hline 0 & 13.5 & $\mathrm{nr}$ & & $\begin{array}{l}\text { Control } \\
\text { sample }\end{array}$ & 112 & 31.1 & $\mathrm{nr}$ \\
\hline 111 & 25.7 & 3.0 & & $\begin{array}{l}\text { Filtered, } \\
\text { centrifuged } \\
\text { sludge }\end{array}$ & 0 & 23.7 & 1.9 \\
\hline 0 & 3.18 & 5.7 & 29 & Raw sludge & ns & ns & ns \\
\hline $216^{4}$ & 3.59 & $\mathrm{nr}$ & 31 & $\begin{array}{l}\text { Centrifuged } \\
\text { sludge }\end{array}$ & ns & ns & ns \\
\hline 0 & 33.5 & $\mathrm{nr}$ & & $\begin{array}{l}\text { Control } \\
\text { sample }\end{array}$ & ns & ns & ns \\
\hline 0 & 24.1 & 2.1 & & $\begin{array}{l}\text { Filtered, } \\
\text { centrifuged } \\
\text { sludge }\end{array}$ & ns & ns & ns \\
\hline
\end{tabular}


Table 4-1. Organic Related Analysis: Average DSC, TGA, and TOC Sludge Sample Results by Waste Depth. ${ }^{7}$ (2 sheets)

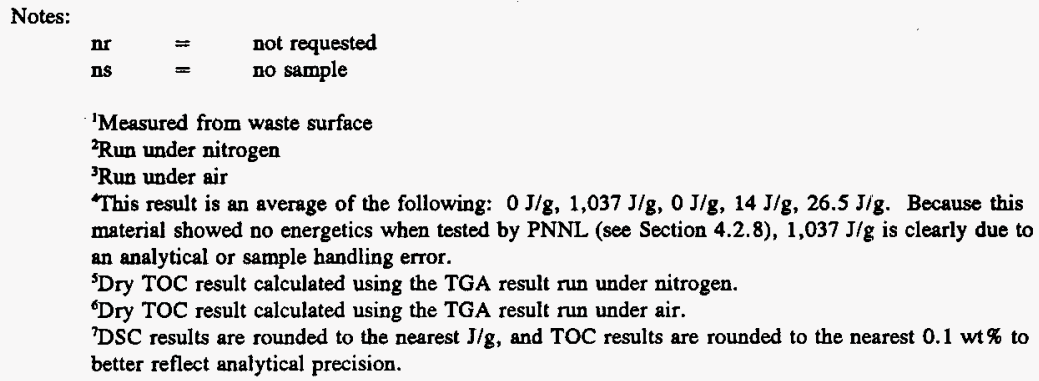

The laboratory staff were asked to dewater the sludge by centrifugation using a filter cone to maximize separation of water-soluble from water-insoluble waste components. The liquid that was obtained from the filtering of the sludge was designated "interstitial liquid, " and the solids were designated "filtered centrifuged solids." In addition to the filtering, a "control sample" of sludge was processed to compare simple centrifuged material with that which had undergone filtration. A third sludge portion underwent a simple centrifugation in a tapered cone to perform density determinations. The liquid portion obtained from the simple centrifugation was designated "decanted supernate," and the solids were designated "centrifuged solids." Any analyses performed on sludge material that had not been processed to remove liquid ("raw" wet sludge) was designated as "sludge (from liquid grab sample)."

The centrifugation that was performed in the tapered cone resulted in the separation of a hitherto unencountered, sludge-associated organic oil that floated on the aqueous layer. This material was designated as "potential organic layer." When this material was observed, the process for dewatering the bulk of the sludge materials was altered. A simple centrifugation step was added to remove most of the liquid as well as the organic oil before the sludge was centrifuged through the filter cones. This "pre-centrifugation" step produced approximately 0.2 to $0.5 \mathrm{~mL}$ of a floating material from an approximately $50-\mathrm{mL}$ sample of "raw" wet sludge. The results of DSC, TGA and TOC analyses on the variety of subsamples of sludge produced by these oil separations and subsequent filtering steps are described below. Information on the nature of the sludge oils so produced are described in Section 4.2.

As can be seen from Table 4-1, the "dewatered" sludge samples obtained from tank C-106 were moderately high in organics (samples $>3 \% \mathrm{TOC}$ ), but were relatively energy poor. Such a result is in keeping with the aging of B Plant organics to sodium oxalate, which is insoluble in the tank wastes. Speciation of sludge samples (see Table 4-2) indeed demonstrated the presence of a significant concentration of sodium oxalate. 


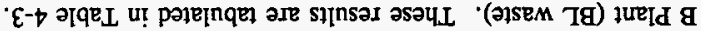

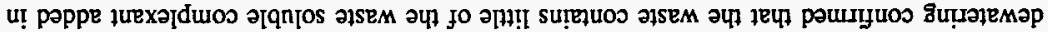

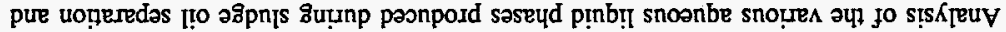

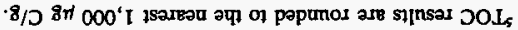

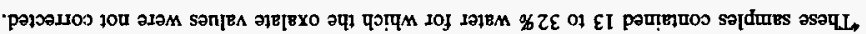

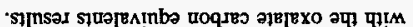

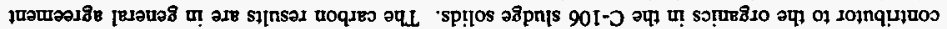
f46oy

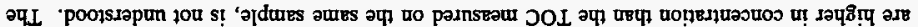

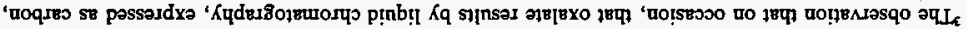

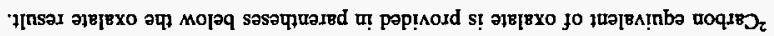

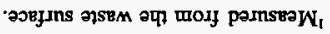
Oृdures or = su

\begin{tabular}{|c|c|c|c|c|c|}
\hline su & su & 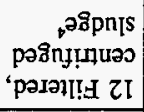 & IE & $\begin{array}{c}\left(00 t^{6} \nabla I\right) \\
006^{\prime} 25\end{array}$ & $000^{\prime} \mathrm{IZ}$ \\
\hline $\begin{array}{c}(\mathcal{E} \text { əION) } \\
\left(00 Z^{\prime} \mathrm{s}\right) \\
00 \mathcal{E}^{\prime} 26\end{array}$ & $000^{\prime} 6 \mathrm{I}$ & 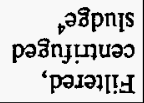 & $\varepsilon Z-6 I$ & $\begin{array}{c}\left(00 L^{\circ} 81\right) \\
009^{\prime} 89\end{array}$ & $000^{\circ} 0 \varepsilon$ \\
\hline $\begin{array}{l}(\varepsilon \text { ə)N) } \\
\left(00 Z^{\prime} \varsigma \varepsilon\right) \\
000^{\prime} 6 Z I\end{array}$ & $000^{\circ} \angle 2$ & 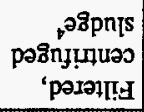 & 9 I-tI & $\begin{array}{l}\left(00 I^{6} I \tau\right) \\
\cos ^{6} \angle L\end{array}$ & $000^{\prime}$ IE \\
\hline 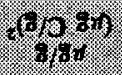 & Whory. & \multirow[t]{2}{*}{ ardians } & \multirow[t]{2}{*}{ (4) } & (t) Whow & 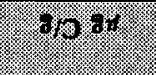 \\
\hline 9141000 & 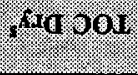 & & & 2114\% & $x^{2}$ \\
\hline \multicolumn{2}{|c|}{ 1. } & ২: & (2) & \multicolumn{2}{|c|}{ 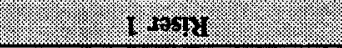 } \\
\hline
\end{tabular}

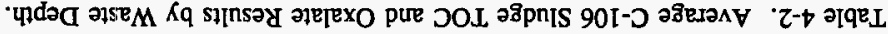


Table 4-3. Organic Related Analysis: Average DSC, TGA, and TOC Liquid Sample Results by Waste Depth. ${ }^{4}$

\begin{tabular}{|c|c|c|c|c|c|c|c|}
\hline \multicolumn{3}{|c|}{ Priser 1 . } & & & \multicolumn{3}{|c|}{ Riser } \\
\hline$\frac{B S 6}{619}$ & $(96)$ & $\begin{array}{l}10 \% \\
(96) \\
(96)\end{array}$ & Beplin & sample gpe & $\begin{array}{l}\text { BSo } \\
3 \% \\
6 \%\end{array}$ & (l) & 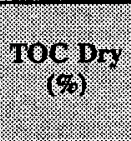 \\
\hline 0 & 80.9 & $\begin{array}{l}1.2^{2} \\
1.7^{3}\end{array}$ & 2 & Supernatant & 0 & 79.3 & $\begin{array}{l}1.0^{2} \\
1.2^{3}\end{array}$ \\
\hline 0 & 35.4 & $\begin{array}{l}0.4^{2} \\
0.3^{3}\end{array}$ & $14-16$ & $\begin{array}{l}\text { Interstitial } \\
\text { liquid }\end{array}$ & 10 & 46.4 & $\begin{array}{l}0.3^{2} \\
0.4^{3}\end{array}$ \\
\hline 0 & 60.3 & $\begin{array}{l}0.6^{2} \\
0.6^{3}\end{array}$ & $19-23$ & $\begin{array}{l}\text { Interstitial } \\
\text { liquid }\end{array}$ & 445 & 75.8 & $\begin{array}{l}0.8^{2} \\
0.8^{3}\end{array}$ \\
\hline 0 & 58 & $\begin{array}{l}0.4^{2} \\
0.5^{3}\end{array}$ & 31 & $\begin{array}{l}\text { Interstitial } \\
\text { liquid }\end{array}$ & ns & ns & ns \\
\hline
\end{tabular}

Notes:

ns $\quad$ no sample

'Measured from waste surface.

${ }^{2}$ TOC performed by direct persulfate oxidation.

${ }^{3} \mathrm{TOC}$ performed by furnace oxidation.

${ }^{4} D S C$ results are rounded to the nearest $\mathrm{J} / \mathrm{g}$, and TOC results are rounded to the nearest $0.1 \mathrm{wt} \%$.

Speciation of the aqueous fraction also confirmed that these layers contain only small amounts of sodium oxalate as compared to their carbon content (Table 4-4). 
Table 4-4. Average TOC and Oxalate Results for C-106 Liquid Samples Analysis.

\begin{tabular}{|c|c|c|c|c|c|}
\hline \multicolumn{2}{|c|}{$\sin ^{2}$} & & & \multicolumn{2}{|c|}{ Riser) } \\
\hline 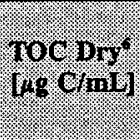 & 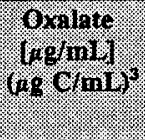 & Depth & sample yos & 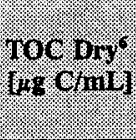 & 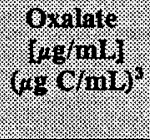 \\
\hline $\begin{array}{l}12,000^{1} \\
17,000^{2}\end{array}$ & $\begin{array}{c}3,680 \\
(1,000)\end{array}$ & 2 & Supernatant ${ }^{4}$ & $\begin{array}{l}10,000^{1} \\
12,000^{2}\end{array}$ & $\begin{array}{r}2,980 \\
(813)\end{array}$ \\
\hline $\begin{array}{l}4,000^{1} \\
3,000^{2}\end{array}$ & I.S. & $14-16$ & Interstitial liquid & $\begin{array}{l}3,000^{1} \\
4,000^{2}\end{array}$ & $\begin{array}{r}3,310 \\
(903)\end{array}$ \\
\hline $\begin{array}{l}6,000^{1} \\
6,000^{2}\end{array}$ & $\begin{array}{l}3,090 \\
(843)\end{array}$ & $19-23$ & Interstitial liquid ${ }^{4}$ & $\begin{array}{l}8,000^{1} \\
8,000^{2}\end{array}$ & $\begin{array}{r}3,290 \\
(897)\end{array}$ \\
\hline $\begin{array}{l}4,000^{1} \\
6,000^{2}\end{array}$ & $\begin{array}{l}2,210 \\
(603)\end{array}$ & 31 & Interstitial liquid ${ }^{4}$ & ns & ns \\
\hline
\end{tabular}

Notes:

$\begin{array}{lll}\text { ns } & = & \text { no sample available } \\ \text { I.S. } & = & \text { insufficient sample to run analysis. }\end{array}$

'TOC performed by direct persulfate oxidation.

${ }^{2}$ TOC performed by furnace oxidation.

${ }^{3}$ Carbon equivalent of oxalate is provided in parentheses below the oxalate result.

These samples were not corrected for their moisture content.

${ }^{5}$ Measured from waste surface.

${ }^{6} T O C$ results are rounded to the nearest $1,000 \mu \mathrm{g} \mathrm{C} / \mathrm{mL}$.

One anomaly observed in comparing TOC and oxalate analysis results was the fact that the 222-S oxalate analysis procedure sometimes resulted in a higher apparent "yield" of sodium oxalate than is bounded by TOC analysis. Because sodium oxalate is quantitatively degraded to carbonate by persulfate oxidation, this anomalous result suggests a matrix interference in the oxalate assay, perhaps another analyte eluting under the oxalate peak.

\subsection{POTENTIAL FOR A PROPAGATING REACTION OF THE RESIDUAL ORGANICS IN TANK C-106 AFTER DRYOUT}

As was noted in Section 3.1, the waste in tank C-106 consists of:

- BL (B-plant low-level complexant waste) from B Plant after the removal of Sr and $\mathrm{Cs}(\mathrm{Pu}$ would not have been removed from this waste type during B Plant $\mathrm{Sr}$ and $\mathrm{Cs}$ removal operations) 
- AR-002 (PUREX sludge) high Sr-Cs-Pu from PUREX (via A-106)

- CWP1 coating waste from PUREX

- UR (Uranium Recovery Wastes) on the tank bottom (so called hardpan).

Only BL wastes should contain organic complexants. Agnew (1995) estimated in his model that much of the organic added to the tank was citrate. However, the B Plant flowsheet indicated that most of the citrate in the waste stream was destroyed by the B Plant evaporator, so the actual carbon-containing species would be citrate degradation products (e.g., oxalate).

This historic information, coupled with the data reported in Section 4.0, suggests that the organics in tank C-106 are both well aged (with large oxalate concentrations) and energetically benign. Therefore, leaving some or all of the organics in tank C-106 in the absence of evaporative cooling will not pose a risk of a propagating organic reaction.

The next section describes the result of speciation of the sludge oil obtained by centrifugation of the C-106 solids.

\subsection{THE COMPOSITION OF THE OIL RELEASED BY SLUDGE CENTRIFUGATION (J. A. Campbell and G. A. Mong, PNNL)}

As was stated in an earlier section, in order to maximize information obtained from the samples recovered from tank C-106, an extensive dewatering step was built into the laboratory test plans (Schreiber 1996). The 222-S laboratory staff was asked to dewater the sludge in a centrifuge using a fritted disk or filter cone to maximize separation of water-soluble from water-insoluble waste components. This "separation" step was designed to avoid the anomalies sometimes observed when samples containing significant amounts of "water" (e.g., > 40\%) are analyzed. Errors in analysis results were of particular concern when a waste sample contained species (analytes) that partitioned in both the aqueous and solid phases. Standard centrifugation in a tapered cone was also performed on the sludge samples. Standard centrifugation resulted in the separation of a hitherto-unencountered, sludge-associated organic oil that floated on the aqueous waste layer. The results of speciation and other tests with C-106-derived "sludge" oil are described below.

\subsubsection{Summary of Findings}

Two of the oil samples centrifuged from tank C-106 sludge were submitted to Pacific Northwest National Laboratory (PNNL) for organic speciation. The oil samples were 7-SA and 13-3 from sludge samples 6C-96-7 and 6C-96-13, respectively. PNNL identified, using a combination of infrared (IR), gas chromatograph/mass spectrometry (GC/MS) and liquid chromatography as the various constituents of the oil, achieving a carbon accountability 
(TOC) of nearly $80 \%$ for the process. The principal constituent of the oil was the compound bis (2-ethylhexyl) phosphoric acid, existing as the sodium salt in the waste. Minor amounts of tributyl phosphate (TBP), normal paraffin hydrocarbon, and the transesterification products of TBP and 2-ethylhexyl alcohol, or of di(2-ethylhexyl) phosphate and butyl alcohol.

This phosphate ester salt was used as a complexing agent in B Plant during the Sr recovery campaigns. The material likely coprecipitated with the sludge when wastes from B Plant were made alkaline before their transfer to the tanks. The absence of a strongly alkaline environment in tank C-106 likely protected this species from hydrolysis. Alternatively, the sodium salt, by analogy with sodium bis-dibutyl phosphate, may be resistant to alkaline hydrolysis.

\subsubsection{Infrared Analysis of the Tank C-106 Oils (S. A. Bryan, PNNL)}

An aliquot of the tank C-106 sample was weighed and carbon tetrachloride was added. The mixture was slurried and anhydrous sodium sulfate was added to remove the water. The carbon tetrachloride extract was analyzed by Fourier transform infrared (FTIR). The FTIR spectrometer was equipped with a zinc selenide attenuated total reflectance solution sample cell that had a transparent optical window in the mid-IR region of interest. Carbon tetrachloride was used as the reference spectrum to subtract the infrared absorbance of the solvent from the sample spectra. All spectra were collected at 4 reciprocal centimeter region.

Comparison of the tank C-106 sample and the reference bis(2-ethylhexyl)phosphate salt materials shows a close match between the two spectra, indicating that the infrared active ingredients in both the tank C-106 sample and the reference material sample are basically the same compounds. The peak locations of each major band in both spectra (reference and sample) match within the resolution of the sample spectrum. In summary, the major infrared active compound in the tank C-106 sample is bis(2-ethylhexyl)phosphate.

\subsubsection{Tank C-106 Species Identification and Quantitation}

Separable oil samples centrifuged from two of the sludge samples from tank C-106 (7-SA and 13-3) were prepared in the 325 West hot cell by dilution with methylene chloride, drying the liquid with sodium sulfate, and filtering out solids using a Pasteur pipette plugged with clean cotton. 
These samples were dried to constant weight in the 329 labs (Mettler PB303² balance sensitivity $\pm 1 \mathrm{mg}$ ) and were found to be: sample identity $7-S A=15 \mathrm{mg}$, sample identity $13-3=22 \mathrm{mg}$. The samples were taken to known volume and aliquotted for analysis (7-SA $=3.75 \mathrm{mg}$ aliquot, $13-3=5.5 \mathrm{mg}$ aliquot).

Each sample aliquot was dissolved in $2 \mathrm{~mL}$ methylene chloride and treated with an additional $2 \mathrm{~mL}$ diethyl ether that had been saturated with hydrochloric acid. The treatment appears to quantitatively transform the sodium bis (2-ethylhexyl) phosphate in the sample into the free acid form, as evidenced by copious amounts of white precipitate $(\mathrm{NaCl})$ forming in the vessel. The aliquots were then reduced in volume to $100 \mu \mathrm{L}$, cooled, and $3 \mathrm{~mL}$ of an uncalibrated solution of ethereal diazomethane added. (Diazomethane is produced by stirring an ethereal slurry of $\mathrm{N}$-methyl-N-nitrosourea over a $40 \% \mathrm{KOH}$ solution (Fieser and Fieser 1967). The esterification is essentially complete immediately; the colored diazomethane is used to visually confirm the presence of excess diazomethane. To ensure complete conversion, the samples were left for one hour in the presence of excess diazomethane before analysis to ensure complete conversion.

Prior GC/MS analysis has tentatively identified other materials related to bis(2-ethylhexyl) phosphate in these samples. The mass spectral signature ions (both EI and CI modes) for this group of organic analytes makes identification of these moieties relatively straightforward. Evidence exists that the following molecules are also present in the sample: butyl bis(2-ethylhexyl) phosphate; tris(2-ethylhexyl) phosphate; and butyl (2-ethylhexyl) phosphate. The presence of butylated species is highly indicative of trans-esterification from TBP or capture of butanol in the sample matrix over the life of the sample. These materials do not appear to be artifacts of sample preparation or analysis.

GC analysis of the major phosphoric ester components versus two independently prepared standards of methyl bis(2-ethylhexyl) phosphate (prepared in the same fashion as detailed above) using sodium bis(2-ethylhexyl) phosphate (supplied by Chem. Services, Westchester, Pennsylvania) was done using an HP $5890^{3}$ GC flame ionization detector (FID) equipped with a low polarity, thin phase capillary column (HP-5, 30m x $0.32 \mathrm{~mm} \times 0.25 \mathrm{~mm})$. A single dilution of TBP (supplied by Aldrich Chemical Company, Milwaukee, Wisconsin) was also prepared. Quantitation of the major components ( $>5 \%$ of the total peak area) is detailed below.

As shown in Tables 4-5 and 4-6, sodium bis(2-ethylhexyl) phosphate is the dominant organic chemical in the oil that separated on centrifugation of tank C-106 sludge. Reasons for this chemical's survival in tank C-106 are not known, but are perhaps related to its lack of solubility in the waste.

${ }^{2}$ Mettler PB303 is a registered trademark of Mettler Electronics, Anaheim, California.

${ }^{3} \mathrm{HP} 5890$ is a trademark of the Hewlett-Packard Corporation, Avondale, Pennsylvania. 
WHC-SD-WM-TI-756, Rev. 0

Table 4-5. Analysis of Sample 7-SA.

\begin{tabular}{|c|c|c|}
\hline Component & 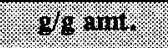 & g Caroong anin \\
\hline D2EHP & 0.66 & 0.37 \\
\hline BuD2EHP & 0.07 & 0.043 \\
\hline T2EHP & 0.01 & 0.005 \\
\hline TBP & 0.05 & 0.027 \\
\hline Bu2EHP & 0.03 & 0.0215 \\
\hline Total & $0.82 \mathrm{~g} / \mathrm{g}$ amt. & $0.46 \mathrm{~g} \mathrm{C} / \mathrm{g}$ amt. \\
\hline
\end{tabular}

Notes:

$\begin{array}{lll}\text { D2EHP } & = & \text { bis(2-ethylhexyl) phosphate } \\ \text { BuD2EHP } & = & \text { butyl bis(2-ethylhexyl) phosphate } \\ \text { T2EHP } & = & \text { tris (2-ethylhexyl) phosphate } \\ \text { TBP } & = & \text { tributyl phosphate } \\ \text { Bu2EHP } & = & \text { butyl (2-ethylhexyl) phosphate }\end{array}$

Table 4-6. Analysis of Sample 13-3.

\begin{tabular}{|c|c|c|}
\hline . Component & g/gint. & 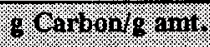 \\
\hline D2EHP & 0.54 & 0.30 \\
\hline BuD2EHP & 0.08 & 0.047 \\
\hline T2EHP & 0.005 & 0.003 \\
\hline TBP & 0.06 & 0.03 \\
\hline Bu2EHP & 0.02 & 0.011 \\
\hline Total & $0.70 \mathrm{~g} / \mathrm{g}$ amt. & $0.39 \mathrm{~g} \mathrm{C} / \mathrm{g}$ amt. \\
\hline
\end{tabular}

Notes:

$\begin{array}{lll}\text { D2EHP } & = & \text { bis(2-ethylhexyl) phosphate } \\ \text { BuD2EHP } & = & \text { butyl bis(2-ethylhexyl) phosphate } \\ \text { T2EHP } & = & \text { tris (2-ethylhexyl) phosphate } \\ \text { TBP } & = & \text { tributyl phosphate } \\ \text { Bu2EHP } & = & \text { butyl (2-ethylhexyl) phosphate }\end{array}$




\subsubsection{PNNL Analysis of Oil Extracted from C-106 Sludge}

The results of preliminary organic speciation analysis of methylene chloride extracts sent to PNNL by the WHC 222-S Laboratory are reported in this section. (See Section 4.2.9 for a description of the $222-S$ extraction process.)

Two samples of a methylene chloride extract of sludge oil were provided by WHC. The were identified as sample 3133 and Sample 3132 . Samples 3133 and 3132 were extracted from oil from sludge samples $6 \mathrm{C}-96-14$ and $6 \mathrm{C}-96-8$, respectively. The major constituent in sample 3133 was D2EHP.

These samples are very similar in composition to the oils centrifuged from the C-106 sludges described in the previous samples. However methylene chloride extraction samples were contaminated with bis(2- ethylhexyl) phthalate a material (e.g., phthalates) usually associated with plasticizers. Sample 3132 contained approximately the same amount of D2EHP as sample 3133, but about 3 times as much bis(2- ethylhexyl) phthalate. This may be simply due to contamination from plasticizers in the plastic centrifuge tubes used in the $222-\mathrm{S}$ Laboratory. Quantitation and carbon balance is in progress.

It should be noted that no normal lab equipment or vessel that PNNL has ever used could would account for the amounts of transesterified plasticizer found in the C-106 extraction samples. However, no similar constraints on materials were placed on the 222-S Laboratory for the solvent extraction procedure. Both samples were delivered in similar containers and were treated identically by PNNL scientists. Although phthalate esters are clearly an artifact of laboratory handling, the cause of the contamination will be pursued since WHC will be checking other sludge waste samples for extractable organics, making avoidance of such contamination a requirement.

\subsubsection{Comparison of Persulfate Quantitation to TOC Furnace Results}

In terms of gram amount, the organic quantitation represents 82 and $70 \%$ of the total observed mass of the samples. The numbers represent the sodium salt forms present in the sample and standard before acidification or methylation. Unfortunately, standard materials are not available for BuD2EHP, T2EHP, or Bu2EHP at this time; the response observed for the major component (D2EHP) was used to calculated these minor components. Both samples contain small quantities of hydrocarbon materials that were not individually quantitated. The sum total of these hydrocarbons may constitute a maximum of $5 \%$ of the total mass of material in the sample. 
Carbon analysis is somewhat more suspect in these analyses. Carbon furnace oxidation (PNL ALO 3814) of the samples (corrected for inorganic carbon using the acidification step of persulfate oxidation [PNL ALO $380^{4}$ ]) gave values of $61.7 \%$ carbon and $55.7 \%$ carbon for sample GSA (duplicate analysis). Sample 13-3 was done in quadruplicate by persulfate oxidation, yielding values of $27.7,33.4,31.3$ and $34.4 \%$ carbon. Furnace oxidation afforded values of $68.7 \%$ carbon, and $62.8 \%$ carbon from D2EHP acid form; this material should exhibit a theoretical maximum TOC of $59.6 \%$ carbon (the values are $15 \%$ and $5 \%$ high, respectively.)

Using the TOC furnace analysis as a benchmark, we have accounted for $78 \%$ of the carbon in sample 7-SA by GC; for sample 13-3, GC analysis accounts for $123 \%$ of the total measured by TOC. If sample 13-3 was not entirely dried when TOC analysis was performed, this error might account for some of the discrepancy.

The check of the carbon balance verification of the speciation results for C-106 centrifuge oil demonstrates that a reasonable carbon balance using fumace oxidation (in these screening experiments) was obtained. The persulfate method does not account for all of the carbon in the C-106 centrifuged oil samples.

\subsubsection{Other Analyses of Tank C-106 Centrifuged Sludge Oil (222-S Laboratory)}

Table 4-7 shows results of DSC, TGA, and TOC analyses performed on the oil samples recovered from the centrifuging of sludge samples. There is no obvious explanation for the variability in the results. The oil layers were difficult to separate from the centrifuged sample and may contain both aqueous materials and solids. However, an examination of the results for the aqueous liquids and solids (Appendix A.2) does not appear to explain the results observed in the oil samples.

Table 4-7. Oil Sample Average DSC, TGA, and TOC Results by

Waste Depth (222-S).

\begin{tabular}{|c|c|c|c|c|c|c|}
\hline \multicolumn{3}{|c|}{$\mathrm{Riser} /$} & & 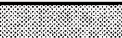 & Riser & \\
\hline 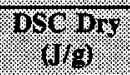 & 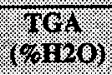 & $(1 \%)$ & $\mathrm{W}_{\mathrm{g}}$ & 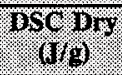 & $(\%)$ & 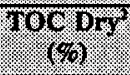 \\
\hline 0 & 35.0 & $\mathrm{nr}$ & $14-16$ & 0 & 29.9 & 3.3 \\
\hline 587 & 69.6 & 10.8 & $19-23$ & 681 & 51.3 & $\mathrm{nr}$ \\
\hline
\end{tabular}

Notes:

$n \mathbf{r}=$ not requested

${ }^{1}$ Measured from waste surface.

${ }^{2}$ TOC results are rounded to the nearest $0.1 \mathrm{wt} \%$.

${ }^{4}$ Internal procedure of Pacific Northwest National Laboratory, Richland, Washington. 


\subsubsection{Plutonium Analysis of Tank C-106 Centrifuge Oil}

An ongoing concern related to criticality is that organic chemicals might lead to concentration of plutonium under tank conditions. Such a concentration has never been known to happen, but the concern has led to a portion of the limited amount of isolated C-106 sludge oil being analyzed for plutonium. These results are reported in Table 4-8. The results indicate no concern for increased plutonium concentrations in the oil samples.

Table 4.8. Oil Sample Average Pu Concentration. ${ }^{1}$

\begin{tabular}{|c|c|c|}
\hline (2. & & $4.6 \mathrm{RHer}^{2}$ \\
\hline (1. & Bepting $\left(\ln ^{2}\right.$ & $\mathrm{p}=2391,40,(1)$ \\
\hline $\mathrm{nr}$ & $14-16$ & 0.0058 \\
\hline 0.0103 & $19-23$ & $\mathrm{nr}$ \\
\hline 0.0012 & 31 & ns \\
\hline
\end{tabular}

Notes:

nr $=$ not requested
ns $=$ no sample available

${ }^{1}$ Results were converted from $\mu \mathrm{Ci} / \mathrm{mL}$ to $\mathrm{g} / \mathrm{L}$ assuming all alpha decay originates from Pu-239

${ }^{2}$ Measured from waste surface.

\subsubsection{Thermal Behavior of Concentrated Extracted C-106 Centrifuge Oil} (R. D. Scheele and D. Alexander, PNNL)

A sample of material obtained from Hanford Site underground storage tank C-106 was received from the 325B Shielded Facility located in the 325 Building in the 300 Area. Aliquots of the sample contained in platinum sample pans were characterized using DSC, simultaneous differential thermal analysis, and TGA at $5^{\circ} \mathrm{C} / \mathrm{min}\left(9^{\circ} \mathrm{F} / \mathrm{min}\right)$. Because the amount of material was limited, two DSC and one differential thermal (DTA)/TGA analyses were performed in a flowing argon atmosphere and one DSC analysis was performed in a flowing air atmosphere. The sample sizes ranged from 3 to nearly $8 \mathrm{mg}$. The material was dark and tarry in appearance.

The combined results of the DSC and the DTA/TGA analyses of the C-106 material in argon, respectively, indicate that no exothermic reactions occurred between the waste constituents up to $480^{\circ} \mathrm{C}\left(896^{\circ} \mathrm{F}\right)$. (Figures showing the results of the DSC/TGA-DTA analyses are available from PNNL). The DSC results for both analyses indicate that several endothermic reactions occur, though not reproducibly. The TGA and the DTA, which 
should be less sensitive than the DSC, indicate that three different principal reactions occur as the material is heated. These reactions appear to start near $100^{\circ} \mathrm{C}\left(212^{\circ} \mathrm{F}\right), 160^{\circ} \mathrm{C}$ $\left(320^{\circ} \mathrm{F}\right)$, and $240^{\circ} \mathrm{C}\left(464^{\circ} \mathrm{F}\right)$. The endothermic reaction heats, as measured by the DSC using the temperature ranges indicated by the TGA for these three reactions, are provided in Table 4-9; due to the difficulties associated with assigning the correct baseline in these two runs, it is recommended that the values reported be considered more qualitative than quantitative. In the absence of chemical information on the nature of the evolved gases, any conjecture about the nature of the reactions that are observed would be speculation. Infrared and/or mass spectrographic analysis of the evolved gases could provide some insight into the nature of the reactions that occur.

Table 4.9. DSC-Measured Enthalpies for the Tank C-106 Organic Sample.

\begin{tabular}{|c|c|c|c|}
\hline \multirow{2}{*}{ 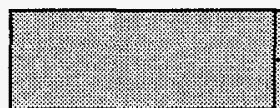 } & \multicolumn{3}{|c|}{ 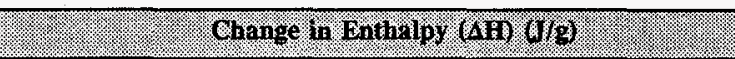 } \\
\hline & (1:- & Saraple: & \\
\hline Temperiture Range & $\begin{array}{l}\text { Rum } 11 \\
2,9 \mathrm{mig}(1 \mathrm{r})\end{array}$ & $\begin{array}{l}\text { Run } \\
6.6 \mathrm{mg}(\mathrm{mr})\end{array}$ & 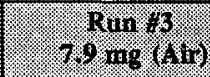 \\
\hline $100-160$ & 55 & 145 & 140 \\
\hline $160-210$ & Not detected & 2 & Not observed \\
\hline $240-360$ & 220 & 145 & \\
\hline $250-450$ & Not observed & Not observed & -890 \\
\hline
\end{tabular}

An 8-mg aliquot of the material was analyzed using DSC in an air atmosphere to determine the susceptibility of the material to reaction with oxygen in the air. The results of that characterization are provided in Table 4-9. As Table 4-9 shows, the material experiences an endothermic reaction between 100 and $160^{\circ} \mathrm{C}\left(212\right.$ and $\left.320^{\circ} \mathrm{F}\right)$ that requires $140 \mathrm{~J} / \mathrm{g}$. Between 250 and $450^{\circ} \mathrm{C}$ ( 482 and $842{ }^{\circ} \mathrm{F}$ ), the material reacts exothermically with the air, producing $890 \mathrm{~J} / \mathrm{g}$. The shape of this exothermic peak suggests that multiple reactions are occurring either due to a stepwise series of reactions or due to the reaction of multiple components in the waste residues with oxygen in the air.

\subsubsection{Organic Extraction Study}

These were the materials, discussed in Section 4.2.4, provided to PNNL for organic speciation studies.

In order to determine the approximate amount of sludge oil coating the sludge in tank C-106, an experiment extracting the oil from uncentrifuged sludge was performed. Because there was limited sample in parent containers and associated archive containers for 6C-96-8 and $6 \mathrm{C}-96-14$, both samples were used. Organic extraction was performed on each sample as 
opposed to duplicates on one sample. The sample was weighed into beakers and gently stirred when methylene chloride was added. No foaming or bubbling were apparent upon addition of methylene chloride or stirring of the resulting mixture. Once the mixture had been stirred for at least 10 minutes, the methylene chloride extract was collected in a $60-\mathrm{mL}$ capped jar (see Table 4-10 for details).

Table 4-10. Organic Sludge Washing.

\begin{tabular}{|c|c|c|c|c|c|c|}
\hline (3) & 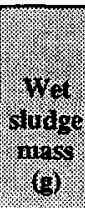 & 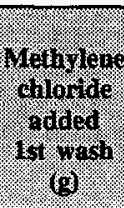 & 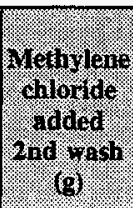 & 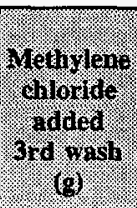 & 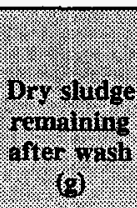 & 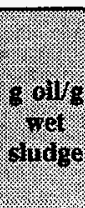 \\
\hline $\begin{array}{l}6 \text { C-96-8, raw sludge, } \\
\text { Riser } 16 \text { (16-19 in. } \\
\text { waste depth) }\end{array}$ & 9.70 & 20.11 & 14.94 & 16.36 & 5.28 & 0.066 \\
\hline $\begin{array}{l}6 \mathrm{C}-96-14, \text { raw sludge, } \\
\text { Riser } 7 \text { (16-19 in. } \\
\text { waste depth) }\end{array}$ & 12.26 & 11.59 & 14.59 & 22.06 & 7.19 & 0.020 \\
\hline
\end{tabular}

Two samples were removed from the extractant mixture for GC/MS analysis. These samples (LABCORE sample number S96T003134), a sample and duplicate, weighed $6.04 \mathrm{~g}$ and 7.72 $\mathrm{g}$, respectively. The remaining sample was then subjected to evaporation by nitrogen sparge to less than $40 \mathrm{~mL}$ of total volume. The solvent was not completely removed within the time frame to release the samples from the hot cell for shipping to PNNL. Evaporation of the remaining solvent was performed at PNNL.

The amount of oil in the sludge was determined to be $0.066 \mathrm{~g}$ oil $/ \mathrm{g}$ sludge for the $6 \mathrm{C}-96-8$ sample and $0.020 \mathrm{~g}$ oil $/ \mathrm{g}$ sludge for the $6 \mathrm{C}-96-14$ sample. The lower oil concentration of the 6C-96-14 sample may have resulted from a $3.11-\mathrm{g}$ sample slurry loss in processing. The sample container was tipped during the first wash and sludge was lost but rinsed with solvent before proceeding with washing the remaining sample. The sludge mass was adjusted for this loss of material to the collection jar after subsequent washings.

\subsection{SAFETY IMPLICATIONS OF OIL RELEASED BY CENTRIFUGATION}

Upon identification of the principal constituent of tank C-106 sludge oil as the sodium salt of bis (2-ethylhexyl) phosphate, samples of this material were purchased by Fauske and Associates for reactive system screening tool and tube propagation tests. Results obtained by Fauske for a $12 \%$ by weight loading of the phosphate in sodium nitrate (Fauske 1996a and 
1996b) indicated that like other simple phosphate ester derived materials found in the tanks, the sodium salt of bis(2-ethylhexyl) phosphoric acid does not show propagating behavior as tested. This finding augments a considerable body of data on butyl esters of phosphoric acid (e.g., TBP and $\mathrm{Na}$ and $\mathrm{Ca}$ dibutyl phosphate) that are considerably less energetic than either their structures or calculation of their theoretical heats of reactions would suggest. Although DSC data obtained in the laboratory on impure portions of oil gave a single ambiguous energetics value, resulting in a large scatter between duplicate runs (Table 4-7), the oil is present in such small amounts (see Section 4.2.9) that it poses no threat from propagating reactions. DSC values reported by PNNL (Section 4.2.8) provide further evidence of the lack of reactivity of the oil.

DSC tests by PNNL on extracted oil are in progress and will be reported when available.

\subsection{ACCIDENTAL OVERHEATING OF INITIAL C-106 SAMPLES (6C-96-1 Through 6C-96-4)}

On February 8, 1996, four samples (two supernatant and two sludge) were obtained from tank C-106 and sent to the WHC 222-S Laboratory. When the samples were loaded into the hot cell for breakdown and subsampling, the four sample bottles were placed into a water bath to bring the samples to tank temperature. Due to a miscommunication of instructions, the water bath was allowed to heat to dryness, resulting in the loss of the two supernate samples (6C-96-1 and 6C-96-2) and the drying out of sludge sample 6C-96-3, whose sample bottle broke. The second sludge sample $(6 \mathrm{C}-96-4)$ was overheated to approximately $200^{\circ} \mathrm{C}$ $\left(392^{\circ} \mathrm{F}\right)$, but the jar remained intact with no apparent drying of the sample. A full suite of analyses was performed on sample 6C-96-4, while a partial suite of analyses (DSC, TGA, TOC, and anions) was performed on sample 6C-96-3. Comparison of the DSC and TOC results for samples $6 \mathrm{C}-96-3$ and $6 \mathrm{C}-96-4$ with the remaining sludge samples shows no significant differences between the two sets of data. 


\subsection{A PARTIAL REEXAMINATION OF WASTE COMPATIBILITY CONCERNS}

\subsection{COMPATIBILITY TESTING AND ORGANIC EXTRACTION (B. A. Crawford, WHC)}

The following sections report the results of centrifuge tests and mixing tests on tank C-106 sludge and combined C-106 and AY-102 sludge with AY-102 supernate. During these tests, no adverse effects (changes in physical properties) were identified that negatively affect the proposed retrieval of C-106 to AY-102 by past practices sluicing.

\subsubsection{Pretesting of Tank AY-102 Sludges for Organic and Tank C-106 Sludges for Organic Separation}

An aliquot of tank AY-102 sludge, identified as 102-AY-9, was collected from riser $15 \mathrm{H}$ at $1,715 \mathrm{~cm}$ (675 in.) prior to addition of caustic to the tank. The sludge was centrifuged at $1,215 \mathrm{G}$ for 10 minutes at approximately $55^{\circ} \mathrm{C}\left(131^{\circ} \mathrm{F}\right)$. After centrifuging, the interstitial liquid volume was $3.0 \mathrm{~mL}$ in $6.5 \mathrm{~mL}$ of bulk sludge material. No organic, which could have separated from the sludge, was evident.

Under similar conditions as those stated above, tank C-106 material was centrifuged at $10 \mathrm{G}$ to mimic pumping conditions. The centrifugation conditions are at least an order of magnitude less than those used for oil recovery. No noticeable separation of organic from the sludge sample or interstitial liquid occurred at these lower centrifuge speeds.

\subsubsection{Supernate Characteristics}

In addition to supernate from sludge sample 102-AY-9, six other supernate samples were checked for foaming. The 102-AY-9 sample was vortexed with no foaming evident. By shaking the supernate; foaming occurred with subsequent breakup in less than 5 seconds. This supernate was not used for compatibility mixing, because it was later learned that the sample was taken from tank AY-102 prior to addition of caustic to the tank. Therefore, six other samples: 2AY-96-1, 2AY-96-2, 2AY-96-3, 2AY-96-4, 2AY-96-5, and 2AY-96-6, which were collected from the tank after the caustic addition (and which are more representative of current conditions), were used. Each of the supernates samples was agitated with variable results.

In all cases where foaming occurred, the dissipation of foam was nearly immediate. Samples 2AY-96-1, 2AY-96-2 and 2AY-96-6 foamed with foam dissipation in less than 20 seconds. Samples 2AY-96-3, 2AY-96-4 and 2AY-96-5 either foamed with immediate dissipation or exhibited no sign of foaming. Because a large amount of supernate was required for the 
tests, three samples (2AY-96-5, 2AY-96-2 and 2AY-96-6) were used to perform the compatibility studies. In each case, key characteristics (i.e., $\mathrm{pH}$ and specific gravity [SpG]) of the supernate were checked before and after mixing with the sludge.

Supernate samples from tank C-106 were also checked for foaming. Supernate samples from the parent samples that correspond to the sludges being tested were observed after agitating. Sample S96T000536 (parent sample 6C-96-8) and sample S96T001547 (parent sample $6 \mathrm{C}-96-14)$ showed foaming with immediate breakup of the foam (within 5 seconds).

\subsubsection{Tank C-106 Sludge Mixed with Neat AY-102 Supernate}

Sludge from tank C-106 parent samples 6C-96-8 and 6C-96-14 were mixed individually with supernate from tank AY-102 (parent sample 2AY-96-5) (see Table 5-1 for details).

Table 5-1. Sludge Mixed with AY-102 (2AY-96-5). ${ }^{1}$

\begin{tabular}{|c|c|c|c|c|}
\hline Shage Wh. & grad. culiniler & vifipht of & $\begin{array}{l}\text { Weight of } \\
\text { Sludge graed }\end{array}$ & 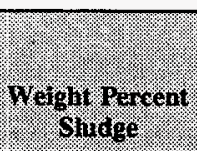 \\
\hline $\begin{array}{l}\text { 6C-96-8 } \\
\text { (S96T000575) }\end{array}$ & A & 53.31 & 9.98 & 11.4 \\
\hline $\begin{array}{l}\text { 6C-96-14 } \\
\text { (S96T001550) }\end{array}$ & $E$ & 37.98 & 3.93 & $\begin{array}{l}6.5 \text { (10.3 wet } \\
\text { sludge basis) }\end{array}$ \\
\hline
\end{tabular}

Note:

'All mixing for the C-106/AY-102 compatibility study was done with a vibrating mixer that induces a vortex in the sample.

The weight percent sludge value for total slurry was approximated for 10 weight $\%$ sludge. The exact concentration of sludge in the mixture was calculated as follows:

$$
\text { Wt. \% sludge }=\frac{W_{1}-W_{2}}{W_{3}+W_{1}} * 100
$$

where $W_{1}=$ mass of wet sludge

$\mathrm{W}_{2}=$ mass of water in sludge $=$ total sludge weight $\mathrm{x} \%$ water content $\mathbf{x} .001$

$\mathrm{W}_{3}=$ mass of supernate. 
The test plan for compatibility (Crawford 1996) study targets testing mixtures of C-106 sludge with AY-102 sludge and supernate at $10 \mathrm{wt} \%$ slurry using dry weight estimates as a basis for dilution factors. The 6C-96-8 sample was actually $11.4 \mathrm{wt} \%$ solids after calculating. The actual concentration of the 6C-96-14 sample was $6.5 \mathrm{wt} \%$. This discrepancy was due to incorrectly accounting for the interstitial liquid content of the sample. The weight percent sludge content in the mixture based on wet sludge, however, is 10.3.

\subsubsection{Settling Behavior of C-106 Sludges with AY-102 Supernates}

After sludge samples $6 \mathrm{C}-96-8$ and $6 \mathrm{C}-96-14$ were combined with tank $\mathrm{AY}-102$ supernate, the supernate was light yellow and clear and the sludge was red-brown with fine, sand-like particles.

Upon mixing, all solids were suspended in the supernate. Separation of solids from the supernate occurred within 10 minutes for both samples of pure (uncentrifuged) sludge from samples 6C-96-8 and 6C-96-14. The sludge from sample 6C-96-14 appeared to be settling out faster than the sludge from the 6C-96-8 sample. The supernate appeared to be clear of suspended solids after 165 minutes ( 2 hours and 45 minutes).

The resultant small $\mathrm{pH}$ changes and changes in physical properties resulting from mixing tank AY-102 supernate and pure tank C-106 sludge are summarized in Table 5-2. Sample 6C-96-8 shows a slight increase in $\mathrm{pH}$ in the suspended slurry and a small decrease in the resultant supernate. Sample $6 \mathrm{C}-96-14$ shows a $\mathrm{pH}$ decrease in the slurry with a slightly larger increase in the resultant supernate. The most obvious difference is observed in the $\mathrm{pH}$ increase in the supernate that was mixed with 6C-96-14 sludge. An increase in the specific gravity is also observed in both samples after mixing the supernate with the C-106 tank sludge. This SpG increase is observed in the supernate, as well as the resultant sludge layers.

Of greater importance, no exotherm was noted for the combined solution, indicating that the energetics of the mixture are not reactive. Interestingly, the water content of the sludges remains fairly high after settling. The sample from 6C-96-14 appears to be particularly high with respect to the 6C-96-8 sample. However, both samples, 6C-96-8 and 6C-96-14 also show increases in solid mass and volume after settling (see Table 5-8).

Sludge from parent sample 102-AY-9 was added to each of two graduated cylinders as described in Table 5-3. With the exception of mixing the sludges in 4 parts tank C-106 sludge to 1 part tank AY-102 sludge proportions, the sludges were combined with supernate from tank AY-102 in similar fashion to those previously described sludges.

When the sludge was mixed with tank AY-102 supernate, no foaming, frothing, or bubble formation occurred. The sludge remained brown and mixed quite well in the supernate. 


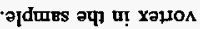

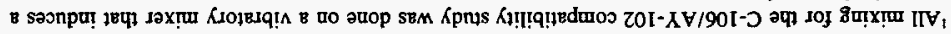

\begin{tabular}{|c|c|c|c|c|c|c|}
\hline$Z \circ O L$ & $L t^{\circ} \Delta S$ & $60^{\circ} t: I$ & $\tau E \mathcal{L}$ & $6 L I$ & a & $\begin{array}{r}(6+5100.196 S) \\
t[-96-09 \\
\end{array}$ \\
\hline 86 & OL'I9 & $\varepsilon 0^{\circ} t: I$ & $\varepsilon I^{-} L$ & $\angle L I I$ & $\mathbf{g}$ & $\begin{array}{r}(S L S 000 L 96 S) \\
8-96-29\end{array}$ \\
\hline 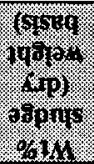 & 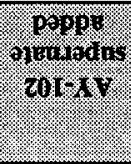 & $\begin{array}{l}9019 \\
0015 \%\end{array}$ & 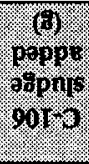 & 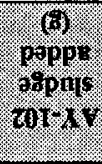 & Hongs & a1 Od dur \\
\hline
\end{tabular}

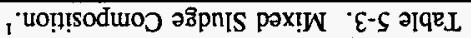

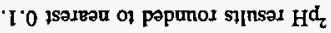

rejen jo jequ saq̨orordds

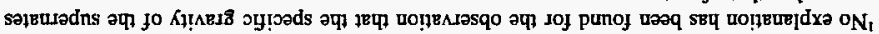

\begin{tabular}{|c|c|c|c|c|c|c|}
\hline$\rightarrow$ & $Z \mathcal{E}^{\prime} I$ & --- & 80.56 & $\begin{array}{c}\text { (å̊pnIs) } \\
z \varsigma^{\circ}[\end{array}$ & --- & $\begin{array}{r}\text { (L28200L96S) } \\
\text { ә8ิpnis 8upjnsəd }\end{array}$ \\
\hline$\cdots$ & -- & --- & --- & $66^{\circ} 0$ & SII & 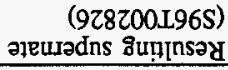 \\
\hline $69^{\circ} \mathrm{L}$ & -- & 0 & $8 L ' 56$ & $\cdots$ & I.II & $\begin{array}{r}(\text { (s28200L96S) } \\
\text { KIInIS } \\
\end{array}$ \\
\hline-- & $\varepsilon 0^{\circ} \mathrm{I}$ & -- & $--\cdot$ & $86^{\circ} 0$ & $\tau^{\prime I I}$ & 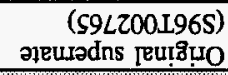 \\
\hline \multicolumn{7}{|c|}{ 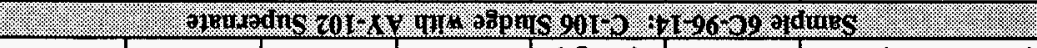 } \\
\hline-- & $E Z^{\prime} I$ & - & $8 L^{\circ} \varepsilon L$ & $\begin{array}{c}\text { (ә8pnIs) } \\
\angle Z \cdot I\end{array}$ & $\cdots$ & $\begin{array}{r}\text { (69L200L96S) } \\
\text { วspnis 1uei]nsoy }\end{array}$ \\
\hline-- & -- & --- & $--\cdot$ & $10^{\circ} \mathrm{I}$ & I'II & 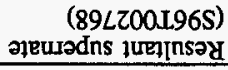 \\
\hline$\$ 8^{\circ} \angle I$ & -- & 0 & $t \tau^{\circ} 96$ & $\cdots$ & $\tau \cdot I I$ & $\begin{array}{r}(99 L 200 L 96 S) \\
\text { Kun[S } \\
\end{array}$ \\
\hline$=-$ & $90^{\circ} I$ & -- & -- & $86^{\circ} 0$ & $\tau$ II & 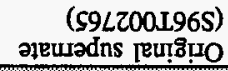 \\
\hline 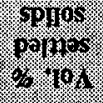 & man & osom & 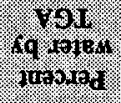 & $(140)$ & 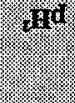 & $\left(\frac{10}{10}\right)$ \\
\hline
\end{tabular}

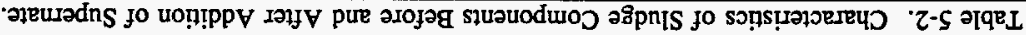


Samples were vortexed until they were thoroughly mixed, and were then allowed to settle. Solids began to separate from the supernate within the first 10 minutes. After 205 minutes ( 3 hours and 25 minutes) had elapsed, the supernate was still cloudy and clearing. The pure sludge samples cleared in less than 2 hours and 45 minutes, and the mixed sludge samples settled over a longer time than the pure tank C-106 sludges. At the next reading $(1,200$ minutes [20 hours]), the supernate was clear and yellow. A more exact time for appearance of clear supernate was not available. The 6C-96-14 mixed sludge dropped out of solution faster than the $6 \mathrm{C}-96-8$ mixed sludge. This behavior is similar to that observed in the previous study, which seems to indicate that some difference in settling behavior may occur as a result of tank location, as well as sludge content, when sluicing occurs, although the settling times are relatively rapid compared to the sluicing operations cycle.

The 6C-96-14 sample settled $52 \mathrm{~mL}$ of suspended sludge within the first 10 minutes (which corresponds to a linear settling velocity of $0.84 \mathrm{~cm} / \mathrm{min}$.), with an initial volume settling rate of $5.2 \mathrm{~mL} / \mathrm{min}$, which is more rapid than the previous run of $6 \mathrm{C}-96-14$ material alone. The mixed sludge 6C-96-8 sample behaved similarly to the analogous tank C-106 sludge sample in all respects. The 6C-96-14 mixed sludge sample may have been more rapid in settling due to its higher concentration of large particles than the other samples. While no particle size analysis was performed to verify it, the tank C-106 sample sludge contained a larger amount of chunks of material than previous samples. The settling rate is reported in Table $5-4$ by time elapsed from initiation of settling.

Table 5-4. Settling Rate by Time Elapsed from Mixing. (2 Sheets)

\begin{tabular}{|c|c|c|c|}
\hline sample W & Time Lapsed & Setting Rate & Mrow \\
\hline \multirow[t]{4}{*}{$6 C-96-8$} & $0-10$ minutes & $2.0 \mathrm{~mL} / \mathrm{min}$ & $3.2 \mathrm{E}-1 \mathrm{~cm} / \mathrm{min}$ \\
\hline & $10-20$ minutes & $1.8 \mathrm{~mL} / \mathrm{min}$ & $2.9 \mathrm{E}-1 \mathrm{~cm} / \mathrm{min}$ \\
\hline & $20-30$ minutes & $0.3 \mathrm{~mL} / \mathrm{min}$ & $4.8 \mathrm{E}-2 \mathrm{~cm} / \mathrm{min}$ \\
\hline & $30-105$ minutes & $0.067 \mathrm{~mL} / \mathrm{min}$ & $1.1 \mathrm{E}-1 \mathrm{~cm} / \mathrm{min}$ \\
\hline \multirow{6}{*}{$\begin{array}{l}6 \mathrm{C}-96-8 \text { with } \\
\text { AY-102 sludge }\end{array}$} & $0-10$ minutes & $1.9 \mathrm{~mL} / \mathrm{min}$ & $3.1 \mathrm{E}-1 \mathrm{~cm} / \mathrm{min}$ \\
\hline & $10-20$ minutes & $2.0 \mathrm{~mL} / \mathrm{min}$ & $3.2 \mathrm{E}-1 \mathrm{~cm} / \mathrm{min}$ \\
\hline & $20-30$ minutes & $0.70 \mathrm{~mL} / \mathrm{min}$ & $1.1 \mathrm{E}-1 \mathrm{~cm} / \mathrm{min}$ \\
\hline & $30-40$ minutes & $0.25 \mathrm{~mL} / \mathrm{min}$ & $4.1 \mathrm{E}-2 \mathrm{~cm} / \mathrm{min}$ \\
\hline & $40-60$ minutes & $0.15 \mathrm{~mL} / \mathrm{min}$ & $2.4 \mathrm{E}-2 \mathrm{~cm} / \mathrm{min}$ \\
\hline & $60-205$ minutes & $0.043 \mathrm{~mL} / \mathrm{min}$ & $6.7 \mathrm{E}-3 \mathrm{~cm} / \mathrm{min}$ \\
\hline \multirow[t]{4}{*}{$6 C-96-14$} & $0-10$ minutes & $2.0 \mathrm{~mL} / \mathrm{min}$ & $3.2 \mathrm{E}-1 \mathrm{~cm} / \mathrm{min}$ \\
\hline & $10-20$ minutes & $1.2 \mathrm{~mL} / \mathrm{min}$ & $1.9 \mathrm{E}-1 \mathrm{~cm} / \mathrm{min}$ \\
\hline & $20-30$ minutes & $0.15 \mathrm{~mL} / \mathrm{min}$ & $2.4 \mathrm{E}-2 \mathrm{~cm} / \mathrm{min}$ \\
\hline & $30-105$ minutes & $0.027 \mathrm{~mL} / \mathrm{min}$ & $4.4 \mathrm{E}-3 \mathrm{~cm} / \mathrm{min}$ \\
\hline
\end{tabular}


Table 5-4. Settling Rate by Time Elapsed from Mixing. (2 Sheets)

\begin{tabular}{|c|c|c|c|}
\hline Sample ID & . & Setting Rate & 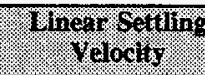 \\
\hline \multirow{5}{*}{$\begin{array}{l}6 C-96-14 \\
\text { with AY-102 } \\
\text { sludge }\end{array}$} & $0-10$ minutes & $5.2 \mathrm{~mL} / \mathrm{min}$ & $8.4 \mathrm{E}-1 \mathrm{~cm} / \mathrm{min}$ \\
\hline & $10-20$ minutes & $1.0 \mathrm{~mL} / \mathrm{min}$ & $1.6 \mathrm{E}-1 \mathrm{~cm} / \mathrm{min}$ \\
\hline & $20-30$ minutes & $0.05 \mathrm{~mL} / \mathrm{min}$ & $8.1 \mathrm{E}-3 \mathrm{~cm} / \mathrm{min}$ \\
\hline & $30-40$ minutes & nd & nd \\
\hline & $40-60$ minutes & $0.05 \mathrm{~mL} / \mathrm{min}$ & $8.6 \mathrm{E}-3 \mathrm{~cm} / \mathrm{min}$ \\
\hline
\end{tabular}

Note:

nd $=$ No difference between volume observations.

Rate constants based on a logarithmic decay of settling over time were calculated according to first order kinetics dependent on volume in $\mathrm{mL}$ (see Figures 5-1 and 5-2). The rate constants for 6C-96-8, 6C-96-8 with AY-102 sludge, 6C-96-14 and 6C-96-14 with AY-102 sludge are: $7.73 \times 10^{-3} \mathrm{~min}^{-1}, 9.22 \times 10^{-3} \mathrm{~min}^{-1}, 1.00 \times 10^{-2} \mathrm{~min}^{-1}$, and $1.03 \times 10^{-2} \mathrm{~min}^{-1}$, respectively, for 215 minutes. While converting the measured settling times to information more suitable for engineering analysis, the laboratory found these "derived" constants are not as intuitive for understanding settling behavior as noting the settling progress depicted in Figures 5-1 and 5-2.

Table 5-5 provides a comparison of supernate and sludge before and after mixing. The $\mathrm{pH}$ decreases when the supernate is mixed with the sludge. This $\mathrm{pH}$ decrease appears to be larger than that observed for $\mathrm{C}-106$ tank sludge alone and undoubtedly is due to the presence of AY-102 sludge. The sludge used for the C-106/AY-102 mixture includes sludge from tank AY-102 which was taken before caustic was added to the tank.

The amount of solids by volume appears to increase once the mixtures have settled. This is illustrated in Table 5-6, where in all cases both the mass and volume of the sludges after settling are significantly greater than the mass and volume of the sludge in the starting material. 
WHC-SD-WM-TI-756, Rev. 0

Figure 5-1. Settling Rate: C-106 in AY-102 Supemate.

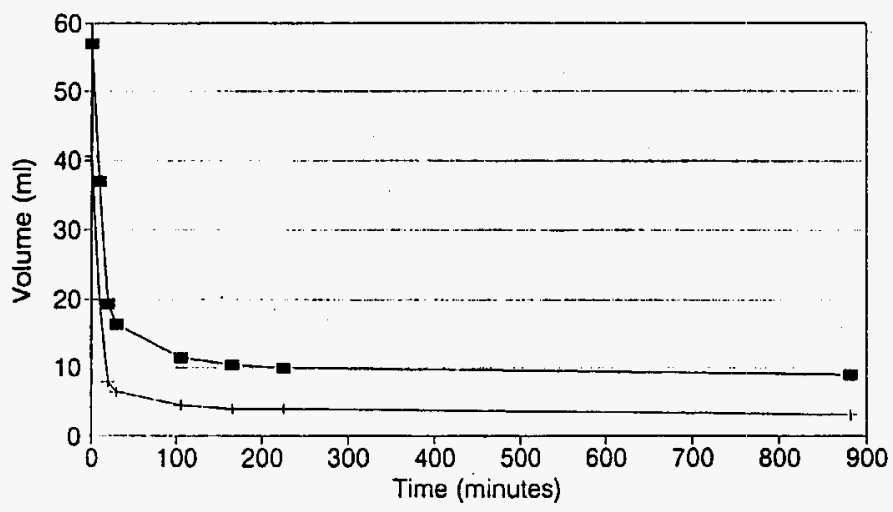

$-\infty-6 C-96-8 \div 6 C-96-14$

Figure 5-2. Settling Rate: Mixed C-106/AY-102 in AY-102 Supernate.

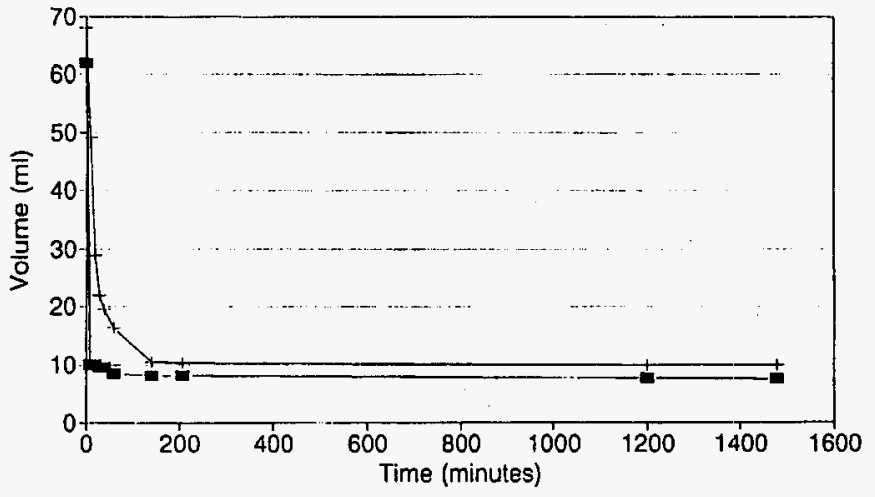

$-\infty-6 C-96-14-16 C-96-8$ 


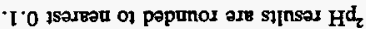

Ioikm jo jeपp saपprosdde

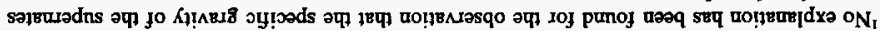

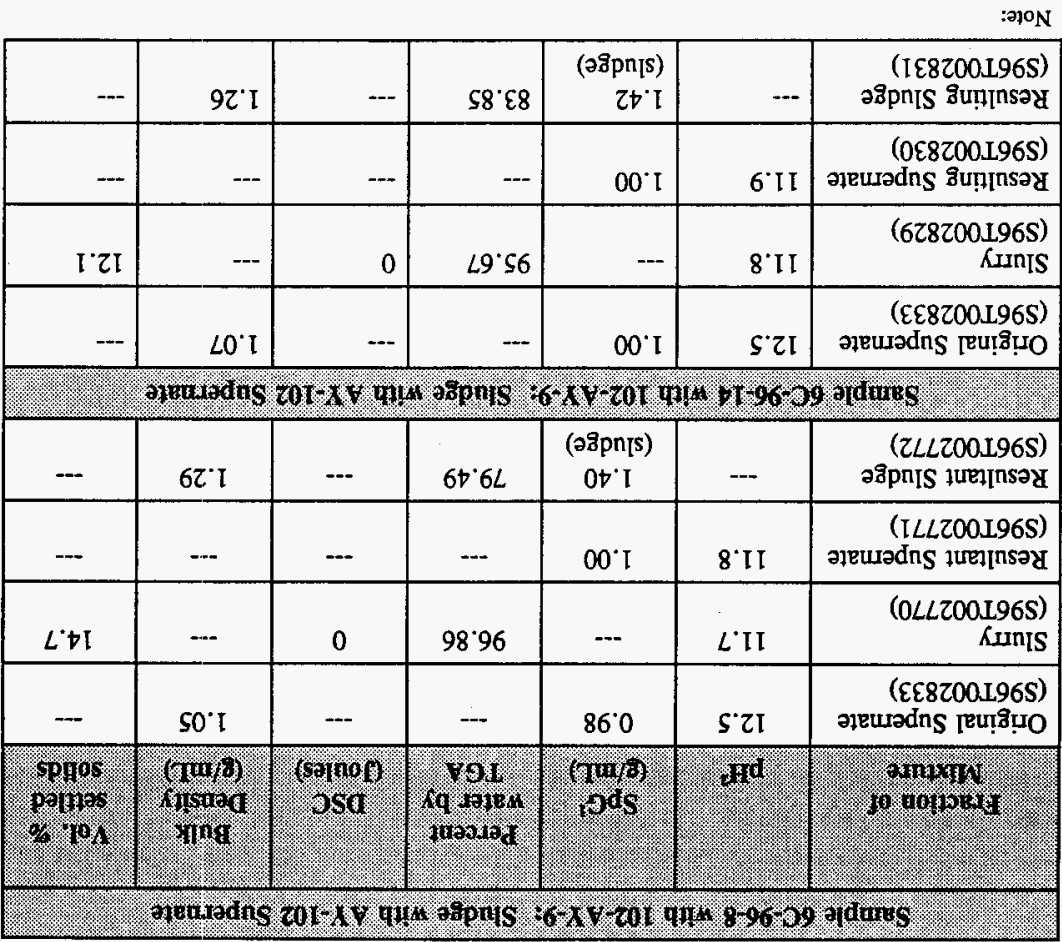

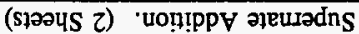

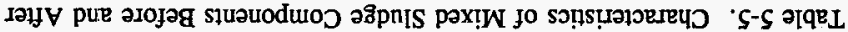


Table 5-6. Solids Before and After Settling.

\begin{tabular}{|c|c|c|c|c|}
\hline ograngerstio & yog. & $60 \% 614$ & $6 \% 868 \%$ & 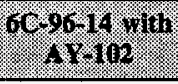 \\
\hline initial mass (g) & 9.98 & 3.93 & 8.9 & 9.11 \\
\hline $\begin{array}{l}\text { initial volume } \\
(\mathrm{mL})\end{array}$ & 9.0 & 3.0 & 10.0 & 7.5 \\
\hline final mass ( $\mathrm{g}$ ) & 22.84 & 14.46 & 60.24 & 32.66 \\
\hline $\begin{array}{l}\text { final volume } \\
(\mathrm{mL})\end{array}$ & 18 & 9.5 & 43.0 & 23 \\
\hline
\end{tabular}

\subsubsection{Sedimentation Studies}

Sedimentation studies were performed via centrifugation at various speeds to mimic hydrostatic forces within the tank and the relation of $G$ forces on sludge oil separation. No oil separation was observed at either low G forces (e.g., low centrifuge revolutions per minute) or short centrifuge times using full power of the laboratory hot cell centrifuge (estimate to be $1,200 \mathrm{G}$ ).

\subsection{THE POTENTIAL FOR CREATION OF A GAS RELEASE EVENT IN TANK AY-102 DURING OR AFTER SLUICING OF TANK C-106}

WHC has evaluated the potential for a GRE resulting from the transfer of tank C-106 solids to double-shell receiver tank AY-102 (Barton 1996). Because it is presently impossible to preclude the possibility of gas buildup as a result of solids transfer, a two-phase strategy for retrieving the waste was promulgated. Because the equipment in tank AY-102 does not meet fire code requirements for a flammable gas environment, partial transfer of the solids will be carried out, and a determination made whether any appreciable amount of slurry growth occurs as a result of a transfer. In the absence of significant slurry growth, retrieval activities will be continued. Should sufficient slurry growth occur $(\sim 25 \mathrm{~cm} \mathrm{[10} \mathrm{in.])} \mathrm{in} \mathrm{tank}$ AY-102, tank mixing will be initiated before the slurry growth reaches the point of risk. It is not known at this time whether such a strategy will allow further sluicing, but modeling of such partial (e.g., ca 50\%) waste transfers (Ogden et al. 1996 and Ogden and Crea 1996) strongly suggests that transferring even half of the tank C-106 solids to tank AY-102 will resolve the high heat issue.

Work by Crawford described in Section 5.1 demonstrates that although the solids from both C-106 and AY-102 disperse easily, they appear to settle relatively rapidly under laboratory conditions. The WHC engineering staff will be evaluating these laboratory results, in terms 
of the physical model for gas accumulation in waste sludges, to see whether our finding reduces the uncertainty with respect to a GRE potential in tank AY-102. (These results will be published separately.)

\subsection{EFFECTS OF DEAGGLOMERATION (TRANSFER LINE PLUGGING)}

The compatibility studies reported in Section 5.1 identified no problem areas resulting from mixing AY-102 supernate with either C-106 and/or combined C-106/AY-102 solids. The compatibility tests described in Section 5.1 were designed explicitly to address CR-SubTAP concerns related to waste compatibility (see Section 2.1). Effects looked for but not found included:

- Ease of sludge oil separation resulting from brief contact" with $G$ forces similar to that found in the sluicing pump (Section 5.1.1)

- Foaming (Sections 5.1.2)

- Slow settling (Section 5.1.4)

- Significant changes in waste viscosity (waste thickening)

- Creation of significant quantities of new solid phases as a result of $\mathrm{pH}$ changes (Sections 5.1.3, 5.1.4, and 5.1.5)

- Gas evolution (Sections 5.1.3, 5.1.4 and 5.1.5).

Considering the apparent ease with which the soft sludges were transferred to tank C-106, such results are not surprising.

Line plugging does not seem to be a compatibility issue associated with the proposed transfer (10\% solids by weight loading) of waste from tank C-106 to tank AY-102. Small but measurable changes in both solution $\mathrm{pH}$ and the density of the settled solids, after mixing, did occur, but these appear to pose no threat to retrieval operations.

\subsection{CONSEQUENCES OF "DISSOLUTION OF SALTS"}

A concern was raised whether a significant amount of potential soluble material was present in tank C-106 and/or tank AY-102 that can dissolve and re-precipitate during retrieval operations (RCR comment 44). The absence from these tanks of significant concentrated evaporator bottoms (or in-tank solidification)-based waste, combined with low sodium and nitrate concentrations, preclude dissolution-solution changes of significance during the proposed retrieval. The only constituent other than to soluble sodium nitrate and nitrite salts that pose a potential "solubility problem" would be aluminum. 
Changes in alkalinity of the wastes resulting from ongoing caustic consumption in tank AY-102 (the hydroxide concentration may truly be dropping at $\sim 0.005 \mathrm{M}$ per month will require the addition of more caustic to tank AY-102 to protect the tank from corrosion. If this trend continues, WHC staff may need to add additional caustic to tank AY-102 as early as August 1996. However, despite the need for additional caustic to raise the $\mathrm{pH}$ to meet DST corrosion specifications, the wastes in the C-106/AY-102 system should not undergo significant long-term swings in alkalinity. The alkalinity range of concern is $0.05 \mathrm{M}$ "free" sodium hydroxide. No significantly enhanced aluminum solubility is expected to result from such tank AY-102 caustic adjustments.

\subsection{WASTE COOLING AND SOLUBILITY CONSIDERATIONS}

Neither tank contains evaporator or in-tank solidification-based waste. (See also Section 5.4). The tank C-106 waste is not saturated with sodium salts and contains little nitrate $(0.6 \mathrm{~mol} / \mathrm{L})$ and nitrite. It is only mildly alkaline. The solution chemistry is dominated by sodium, and carbonate, nitrate, and nitrite anions. It is predominantly an aluminum-iron-calcium, lead, and nickel mixture with hydroxides (as part of metal oxyhydroxide precipitates), carbonate, phosphate and silicate being the dominant anions.

Because the dominant wastes have precipitated, and the aqueous layers are unsaturated with respect to both sodium and nitrate, and cooling associated with retrieval of tank C-106 should have little effect on the amount of solids in the C-106/AY-102 system.

\subsection{STORED ENERGY (Lattice Energy in Crystals)}

A concern was raised by Brookhaven scientists (Appendix A.1, RCR comment 35) that actinides trapped in a crystal matrix can store energy (e.g., Wigner energy) in the waste as a result of lattice disruptions in crystalline particles larger then 1 nanometer in size.

Specifically the issue raised was "Do the precipitated (in)soluble materials contain trapped electrons, lattice defects, etc. that will liberate heat on dissolution?"

An example of lattice energy storage provided by the Brookhaven staff describes crystal-stored alpha lattice energy strain from decay of $96 \mathrm{~kg}$ of $\mathrm{Pu}$ (graphite was referenced as the storage material, but no specific literature reference was provided by Brookhaven National Laboratory [BNL] staff). The BNL staff, however, suggested $10+9$ joules may be stored over a 10-year period in a graphite plutonium matrix.

When one calculates the effect, assuming, for conservatism, that the waste behaves similarly to graphite, one can calculate how many $\mathrm{J} / \mathrm{g}$ might be stored. 
Assume 746,000 L of waste: general laydown considerations suggest that there is in tank C-106 about $91,000 \mathrm{~L}$ of hardpan residues (13\%) from UR and CWP1 heels in 1954 and $655,000(87 \%) \mathrm{L}$ of other sludge (BL and AR Solids). Further assume a coriservative waste density $=1.4 \mathrm{~g} / \mathrm{mL}$.

Calculation: $746,000 \mathrm{~L} \times 1.4 \mathrm{~g} / \mathrm{mL}=1,044,000 \mathrm{~kg}$ of waste or $1.044 \times 10+9$ grams of waste --> or about $1.044 \mathrm{~J} / \mathrm{g}$ wet basis. Assuming sludge is at least $55 \%$ solids by weight, this becomes $1.9 \mathrm{~J} / \mathrm{g}$ dry weight basis. If one uses the BNL estimate that all the energy is stored in the bottom $13 \%$ of the waste (hardpan), then the result would be $14.6 \mathrm{~J} / \mathrm{g}$.

Because the criteria for waste energy concerns, by analogy with the organic and ferrocyanide issues, is $1,200 \mathrm{~J} / \mathrm{g}$ dry weight basis, such modest amounts of stored energy should not be of concern.

A literature report on stored energy in sodium chloride (Jenks et al. 1975), obtained from D. Powers of Sandia National Laboratories, describes the effects of dissolving sodium chloride that had been previously irradiated, under dry conditions, with gamma energy. The magnitude of these effects was approximately equal to the heat of formation of crystalline sodium chloride, which is $98 \mathrm{kcal} / \mathrm{mol}(\sim 1.7 \mathrm{kcal} / \mathrm{mol})$. However, there is no indication that sodium chloride can store energy when irradiated in solution or with crystals in contact with aqueous media. According to Dr. Powers, in crystalline salts in contact with water (e.g., sodium nitrate and nitrite), phenomena such as Ostwald ripening would interfere with energy accumulation.

Ongoing evaluation of DSCs for waste samples that do not contain significant quantities of either ferrocyanide or TOC does not show identifiable excess energy on heating, which would be the case if lattice energy storage were a significant waste energy factor in Hanford Site waste.

More interestingly, data from PNNL (G. J. Lumetta and coworkers) and Los Alamos National Laboratory sludge washing wastes with 23 waste solids from different tanks (but not specifically C-106 waste) indicate that although sludge compositions vary widely in different tanks, these insoluble wastes are amorphous or microcrystalline and are predominantly between 0.1 and 20 microns in size. Larger size particles, when present, at times appear to deaggregate when stirred and washed (e.g., condition in effect in sluicing), forming materials that settle more slowly than the original sampled materials, perhaps due to fluffing phenomena.

The principal author can find no credible risk associated with storage of crystal lattice energy in the C-106/AY-102 system. 


\subsection{TOXIC GAS CONCERNS}

The CR-SubTAP raised the question of "How much and what kinds of toxic gas will be released (during retrieval)? (Part of RCR 37)"

No sampling of the riser exhaust line for ammonia was possible in the time available for this study. However, plans are being implemented to get baseline headspace concentration data for tanks C-106 and AY-102 prior to starting sluicing. This data, coupled with gas monitoring and establishing gas concentration controls during sluicing (with cool dilute waste solution), should assure safety with respect to toxic gases.

All Hanford Site tanks contain appreciable amounts of ammonia and can contain a myriad of other trace constituents with varying toxicological concerns, as evidenced by gas sampling in the dome space. Air Permit requirements with Washington State Department Ecology assure that the retrieval of C-106 to AY-102 will be protective of both the environment and the health and safety of on and off site workers. As long a gas monitoring related controls are in place and are being implemented (WHC 1996), no special concerns about toxic gas exist.

\subsection{A SELECTIVE COMPARISON RECENT OF AY-102 RESULTS PAST SAMPLING EVENTS}

The most recent compatibility sampling and analysis results from tank 24-AY-102 are from November 1995. Comparison of these results with the results summarized in Sederburg (1994) show that most constituents appear to be comparable. However, a detailed evaluation of the complete data sets was not possible due to time constraints. It should be noted that caustic was added in January 1996 to tank AY-102 to bring it back to corrosion control specifications. Because of this addition, the composition of the tank AY-102 waste and future analysis results may differ from the 1995 compatibility results. These minor differences in alkalinity do not affect the conclusions reached in this document. 
WHC-SD-WM-TI-756, Rev. 0

This page intentionally left blank. 


\subsection{OBSERVED RADIOCESIUM AND STRONTIUM DISTRIBUTION}

Concerns were expressed by the CR-SubTAP about "whether C-106 waste can be adequately understood (especially with regard to distribution of heat-generating materials) without the use of additional core samples. Without an understanding of high-heat materials distribution, any basis for estimating heat source removal rate or proportion is questionable (Appendix A.1, RCR 12).

Two parallel approaches were used to support the case that an adequate understanding of high-heat materials distribution in tank C-106 existed. First, modeling of a variety of scenarios associated with different heat distribution cases (Ogden $1996 \mathrm{a}$ and 1996b) demonstrated that even where all the heat load was confined to the hardpan layer (a bounding case), dryout of tank C-106 would pose no risk with respect to thermally related tank failure concerns after soft sludge retrieval. This bounding case assumed a hardpan layer $45 \mathrm{~cm}$ ( $1.5 \mathrm{ft}$ ) thick at the center of the tank and a best estimate of thermal conductivity for dry waste.

Second, the sludge samples retrieved from tank C-106 were analyzed for radiocesium and strontium, as reported in Tables 6-1 and 6-2. This information has been provided the modelers as a means of allowing them to determine that the cases studies did indeed encompass the actual conditions in the tank. Although the quantities of heat-generating materials found in the upper portions of the sludge were lower then that found in the 1986 core composite (Sederburg 1994), the modeling efforts have factored in the recent findings and indicate that these pose no threat to the proposed retrieval operation and outcome.

\subsection{C-106 SLUDGE GRAB SAMPLING RESULTS}

Tables 6-1 and 6-2 contain data on the radiocesium and radiostrontium concentrations found from the most recent sampling of tank C-106.

In addition, information on dose measurements taken during the April 19, 1986 core sampling of tank C-106 was identified (see Appendix A.3) and the assay information passed on to the WHC modelers as an added source of information on the heat distribution in tank C-106. The recent assays appear bounded by recent modeling results. 
Table 6-1. Average Radio Sr and Cs Concentration Sludge Solids Results From C-106 Sludge Grab Samples.

\begin{tabular}{|c|c|c|c|c|c|}
\hline \multicolumn{6}{|c|}{ 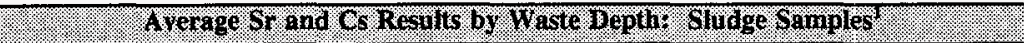 } \\
\hline \multicolumn{2}{|c|}{$350.1 \%$} & \multicolumn{2}{|l|}{ 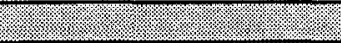 } & \multicolumn{2}{|c|}{ Arser. } \\
\hline $8 \% 00 \% \mathrm{gl}$ & $6 \cdot 18 \%(3)$ & Deprin & Sample $\mathrm{kpe}$ & $5100(4)$ & $(9-1)$ \\
\hline 4.15E-03 & $8.11 \mathrm{E}-03$ & 14-16 & Control sample & $3.99 \mathrm{E}-03$ & $7.18 \mathrm{E}-03$ \\
\hline $6.41 \mathrm{E}-03$ & $1.20 \mathrm{E}-02$ & & $\begin{array}{l}\text { Filtered, centrifuged } \\
\text { sludge }\end{array}$ & 5.27E-03 & 8.31E-03 \\
\hline $2.07 \mathrm{E}-03$ & $3.74 \mathrm{E}-03$ & $19-23$ & Control sample & 9.43E-03 & $1.42 \mathrm{E}-02$ \\
\hline $7.79 \mathrm{E}-03$ & $1.23 \mathrm{E}-02$ & & $\begin{array}{l}\text { Filtered, centrifuged } \\
\text { sludge }\end{array}$ & $7.23 \mathrm{E}-03$ & $1.56 \mathrm{E}-02$ \\
\hline $6.43 \mathrm{E}-03$ & $1.12 \mathrm{E}-02$ & 31 & Control sample & ns & ns \\
\hline $7.48 \mathrm{E}-03$ & $1.12 \mathrm{E}-02$ & & $\begin{array}{l}\text { Filtered, centrifuged } \\
\text { sludge }\end{array}$ & ns & ns \\
\hline
\end{tabular}

Notes:

$\begin{array}{lll}\text { nr } & = & \text { not requested } \\ \text { ns } & = & \text { no sample }\end{array}$

'Results were converted from $\mu \mathrm{Ci} / \mathrm{g}$ to $\mathrm{g} / \mathrm{L}$ using the density of the centrifuged sludge for each sample.

${ }^{2}$ Measured from waste surface.

Table 6-2. Average Radio Sr and Cs Concentration Results From C-106 Liquid Grab Samples.

\begin{tabular}{|c|c|c|c|c|c|}
\hline \multicolumn{6}{|c|}{ 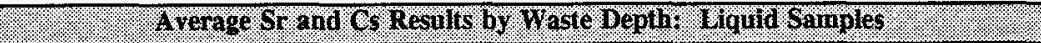 } \\
\hline \multicolumn{2}{|c|}{ Ritser I } & \multirow{2}{*}{$\begin{array}{l}\text { Bephr } \\
(10 \%)\end{array}$} & \multirow[b]{2}{*}{ Sample S Me } & \multicolumn{2}{|c|}{ wiser ? } \\
\hline SHo: ( $(911)$ & 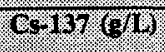 & & & (r.molg) & (SWT (g) \\
\hline $2.63 \mathrm{E}-06$ & $1.24 \mathrm{E}-03$ & 2 & Supernatant & $3.48 \mathrm{E}-06$ & $1.26 \mathrm{E}-03$ \\
\hline $6.70 \mathrm{E}-06$ & $1.02 \mathrm{E}-03$ & 14-16 & Interstitial liquid & $4.82 \mathrm{E}-06$ & $1.40 \mathrm{E}-03$ \\
\hline $6.71 \mathrm{E}-06$ & $1.77 \mathrm{E}-03$ & $19-23$ & Interstitial liquid & $5.49 E-07$ & $1.76 \mathrm{E}-03$ \\
\hline 5.84E-06 & $1.83 \mathrm{E}-03$ & 31 & Interstitial liquid & ns & ns \\
\hline
\end{tabular}

Notes:

ns $=$ no sample

'Measured from waste surface. 


\title{
6.2 A SUMMARY OF STRONTIUM ANALYSIS RESULTS FROM THE 1986 CORE SAMPLE
}

In 1986, a full-depth core sample was obtained from tank C-106. Analyses were performed on the drainable liquid from the core, as well as on a solid composite sample. The solid core composite was made by combining weight fractions of each core segment (Weiss 1987). The strontium results found during this analysis are shown in Table 6-3.

Table 6-3. Sr-90 Results from 1986 Core Sampling of Tank C-106. ${ }^{d}$

\begin{tabular}{|c|c|c|}
\hline 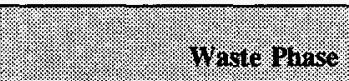 & Resull $(4)$ groor & 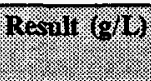 \\
\hline Solid Core Composite & 1980 & $0.0204^{2}$ \\
\hline Drainable Liquid & 1650 & 1.19E-05 \\
\hline
\end{tabular}

Notes:

\author{
'Weiss (1987) \\ ${ }^{2} \mathrm{R}$ esult converted from $\mu \mathrm{Ci} / \mathrm{g}$ to $\mathrm{g} / \mathrm{L}$ using the density result of $1.43 \mathrm{~g} / \mathrm{mL}$.
}

\subsection{COMPARISON OF RECENT GRAB SAMPLES IN TANK C-106 WITH 1986 CORE SAMPLE AND THERMAL MODELING (T. J. Bander, WHC)}

Recent grab samples of sludge from tank C-106 have been analyzed for Sr-90 and Cs-137 content. A comparison of the total heat source estimates based on these samples, the sample taken in 1986, and the value used in the thermal modeling, has been done. This comparison is shown in the tables below.

The grab samples were taken from depths between 35 and $76 \mathrm{~cm}$ (14 and 30 in.) below the waste surface. This region is part of the top layer of sludge used in the thermal modeling, and was formed from the noncomplexed waste added to the tank between 1977 and 1979. The top layer consists of relatively low amounts of heat generation materials compared to the amounts in the layers below it, the bottom two layers in the thermal model. The thermal model assumes three layers of sludge.

In order to compare the 1996 samples and the 1986 homogenized sample, an estimate of the strontium and cesium for a homogenized sample of the 1996 samples was done. The calculations of homogenized concentrations for the 1996 samples assumed that the ratio of the radionuclide concentrations between the bottom two layers and the top layer was the same as that used in the thermal modeling (a ratio of 4.2). That is, the concentration of radionuclide material is a factor of 4.2 higher in the bottom two layers than in the top layer. Because the grab samples were obtained from the top layer of sludge, the radionuclide concentration in the bottom two layers is assumed to be 4.2 times higher than what was 
measured in the grab samples. The volumes of the sludge layers assumed in calculating homogenized 1996 concentrations are those used in the thermal model (397 kL [105 kgal] in the bottom two layers and $348 \mathrm{~kL}$ [ $92 \mathrm{kgal}$ ] in the top layer). Maximum and average measured values of concentration obtained from the grab samples were used in the homogenized 1996 sample calculations (see Tables 6-4 and 6-5). The homogenized concentration of Sr-90 in the 1986 sample falls between the homogenized values using maximum and average measured concentrations of the 1996 samples. The Cs-137 comparison indicates much higher concentrations in the 1996 samples compared to the 1986 sample.

Table 6-4. Strontium and Cesium Concentrations in Samples (Risers 1 and 7 Combined in 1996 Sample).

\begin{tabular}{|c|c|c|c|}
\hline & 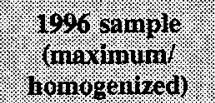 & $\begin{array}{l}1906 \text { sample } \\
\text { (averoger } \\
\text { bomogenized }\end{array}$ & 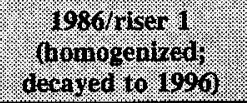 \\
\hline & Shinjle roon rop & Sariple hor & Sample grom erifo \\
\hline \multicolumn{4}{|l|}{$\begin{array}{l}\text { sludge } \\
(\mu \mathrm{Ci} / \mathrm{g})\end{array}$} \\
\hline Sr-90 & $862 / 2336$ & $533 / 1444$ & 1611 \\
\hline Cs-137 & $890 / 2412$ & $572 / 1550$ & 269 \\
\hline \multicolumn{4}{|l|}{$\begin{array}{l}\text { liquid } \\
(\mu \mathrm{Ci} / \mathrm{mL})\end{array}$} \\
\hline Sr-90 & $0.932 / 2.525$ & $0.609 / 1.65$ & 1.34 \\
\hline Cs -137 & $158 / 428$ & $127 / 344$ & 22.6 \\
\hline
\end{tabular}


Table 6-5. Strontium and Cesium Concentrations in Solids of Samples (Risers 1 and 7 separate).

\begin{tabular}{|c|c|c|c|}
\hline & 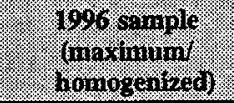 & 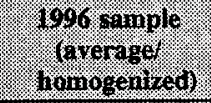 & $\begin{array}{l}(906 \text { rimile } \\
(\text { comogenived) }\end{array}$ \\
\hline & 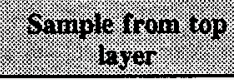 & 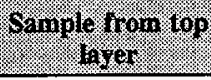 & 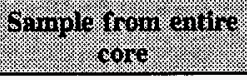 \\
\hline \multicolumn{4}{|l|}{$\begin{array}{r}\text { Riser \#1 } \\
(\mu \mathrm{Ci} / \mathrm{g})\end{array}$} \\
\hline Sr-90 & $693 / 1878$ & $488 / 1322$ & 1611 \\
\hline Cs- 137 & $644 / 1745$ & $516 / 1398$ & 269 \\
\hline \multicolumn{4}{|l|}{$\begin{array}{r}\text { Riser \#7 } \\
(\mu \mathrm{Ci} / \mathrm{g})\end{array}$} \\
\hline Sr-90 & $862 / 2336$ & $603 / 1634$ & na \\
\hline Cs-137 & $890 / 2412$ & $656 / 1778$ & na \\
\hline
\end{tabular}

Note: na $=$ not applicable

Table 6-6. Heat Source Using Homogenized Concentrations (Btu/hr) (Decayed to 1996).

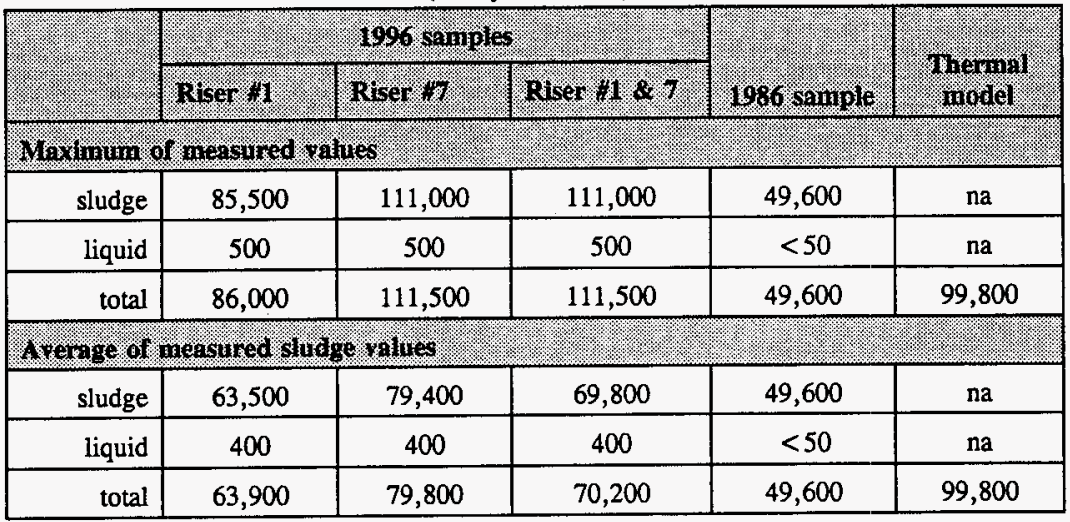

Note: $n a=$ not applicable 
The calculations using the maximum measured values give an upper bound for the heat source and the calculations using the average measured values give a best estimate for the heat source. The estimates of the heat source from the 1996 samples is consistent with estimates used in the thermal modeling (Table 6-6). The variability in the sample values and the uncertainties in the nuclide distribution in the sludge can account for the differences in the estimates of heat source from the 1996 samples, the 1986 sample, and the thermal modeling. 


\subsection{OBSERVED PLUTONIUM DISTRIBUTION (L. A. Tusler, WHC)}

As part of the recent tank C-106 grab sampling event, analysis for fissile materials in the top 76 of $178 \mathrm{~cm}$ (30 of $70 \mathrm{in}$.) of sludge was carried out. These results are reported in Tables 7-1 and 7-2. These results are being evaluated by WHC's nuclear criticality experts and will be reported in the final version of Waltar (1996).

According to the Tank Farm Criticality Safety Representative, the plutonium concentrations reported for the supernatant are comparable to historical plutonium supernatant concentrations in tank C-106. The average plutonium concentrations reported for the supernatant (Table 7-1) are higher than average plutonium concentrations reported for historical samples, but similar to the maximum plutonium concentrations from historical samples (Sederburg 1994).

Sludge samples taken in 1986 and 1987 have a plutonium concentration of $0.069 \mathrm{~g} / \mathrm{L}$. A 1980 sample from tank C-106 has a maximum plutonium concentration in the sludge of $0.127 \mathrm{~g} / \mathrm{L}$. The average plutonium concentration of the 1980 sludge samples was $0.076 \mathrm{~g} / \mathrm{L}$ (Sederburg 1994). All of the historical values are higher than the plutonium concentrations reported for the 1996 sludge grab samples (Table 7-2). This finding is not unexpected because the maximum concentration of plutonium-bearing waste might be expected to be found at depths greater than samples could be obtained with the sludge "bottle" sampling device. Alternatively, the present estimates of the inventory in tank C-106 may be too high.

The plutonium concentrations in the interstitial liquid $(0.013 \mathrm{~g} / \mathrm{L}$ and $0.0124 \mathrm{~g} / \mathrm{L})$ of the 1996 sludge samples appear to be consistent with historic plutonium concentrations in supernatant and interstitial liquid samples.

The method of sampling used for the historical samples was different than the method used for the 1996 sampling event. Therefore, differences in the plutonium concentrations should be expected.

In conclusion, the criticality staff compared the most recent C-106 grab sample data (Tables 7-1 and 7-2) with the data used in the W-320 Safety Analysis (WHC 1996) and the data from CSER 94-001 (Rogers 1994). The general conclusions reached in the W-320 document are still valid using the new grab C-106 grab sample data. The Pu concentrations from the C-106 grab samples are somewhat different than the concentrations used in CSER 94-001 and the W-320 report. The Pu concentrations in the supernate are comparable to previous supernate samples. The $\mathrm{Pu}$ concentrations in the sludge are lower than values reported from previous sampling events $(\mathrm{Pu}=0.0434 \mathrm{~g} / \mathrm{L}$ from the high-value grab samples compared to high $\mathrm{Pu}=0.127 \mathrm{~g} / \mathrm{L}$ from core sample). This is not unusual because the methods of sampling are different. 


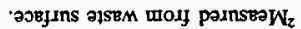

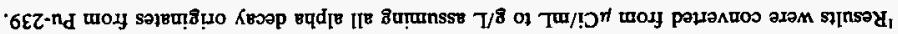

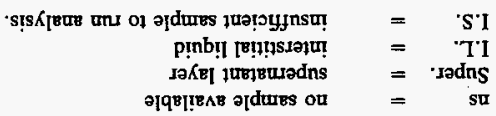

\begin{tabular}{|c|c|c|c|c|c|c|c|}
\hline su & su & su & $\mathrm{T} I \mathrm{I}$ & I $\varepsilon$ & $20.0>$ & $20.0>$ & $8 \varepsilon 10^{\circ} 0$ \\
\hline $650^{\circ} 0$ & $850^{\circ} 0$ & $\triangle 2 T 0^{\circ} 0$ & 7.1 & $\varepsilon \tau-6 \mathrm{I}$ & $20^{\circ} 0>$ & $20^{\circ} 0>$ & દEI00 \\
\hline $20^{\circ} 0>$ & $20^{\circ} 0>$ & SEI0 0 & ${ }^{\prime} \mathrm{I} I$ & $9 I-t I I$ & 'S'I & 'S'I & $\varepsilon Z I 0^{\circ} 0$. \\
\hline$\varepsilon 0^{\circ} 0>$ & $\varepsilon 0^{\circ} 0>$ & SZTO०0 & - rodns & $\tau$ & $20.0>$ & $20.0>$ & SIIO० 0 \\
\hline$(100) .4$ & (169) 11 & 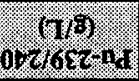 & & & 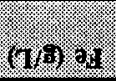 & $(\sqrt{n}) \mathrm{s}$ & 0.27680 \\
\hline & $2.8+10$ & & $\begin{array}{l}\text { adui } \\
\text { gitures }\end{array}$ & (1) & & 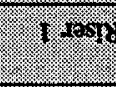 & Yl: \\
\hline
\end{tabular}

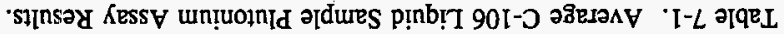

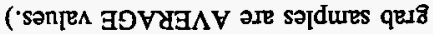

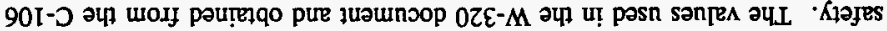

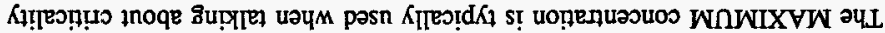

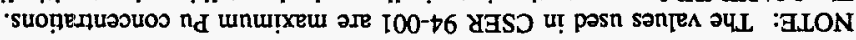


Table 7-2. Average C-106 Sludge Samples Plutonium Assay Results.

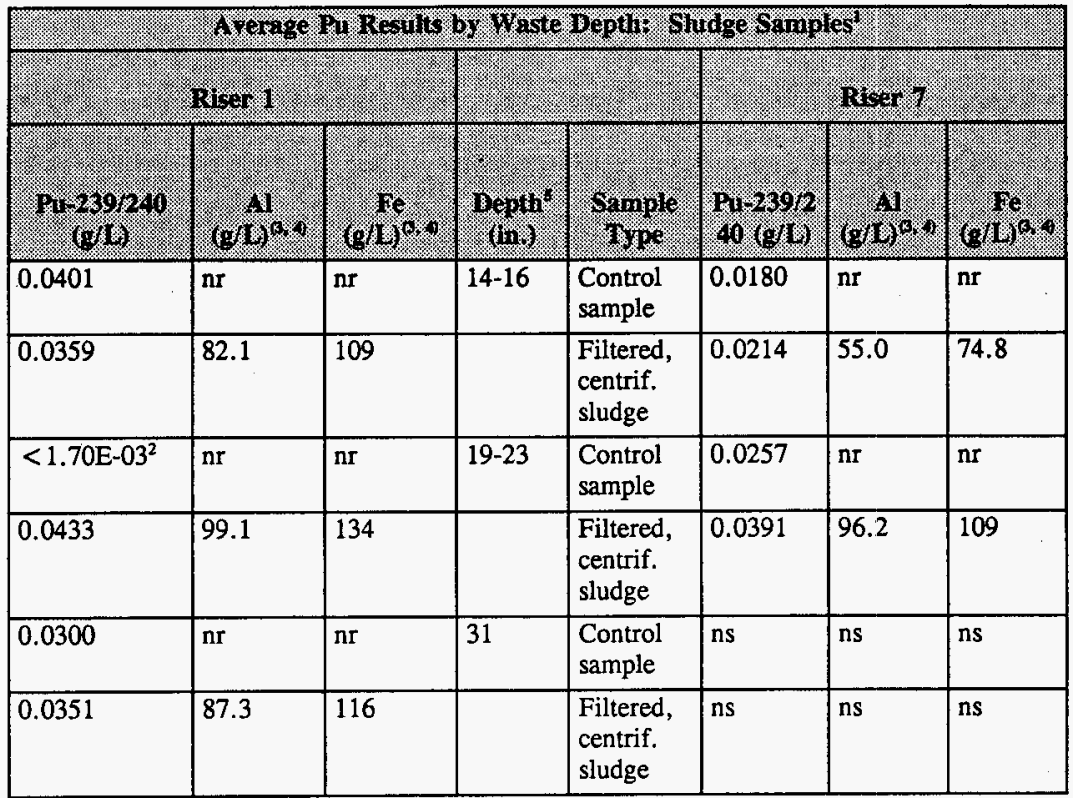

Notes:

$\begin{array}{lll}\text { nr } & = & \text { not requested } \\ \text { ns } & = & \text { no sample available }\end{array}$

'Results were converted from $\mu \mathrm{Ci} / \mathrm{g}$ to $\mathrm{g} / \mathrm{L}$ using the density of the centrifuged sludge for each sample and assuming all alpha decay originates from Pu-239.

${ }^{2}$ Insufficient sample to rerun analysis.

${ }^{3} \mathrm{Al}$ and $\mathrm{Fe}$ results converted from $\mu \mathrm{g} / \mathrm{g}$ to $\mathrm{g} / \mathrm{L}$ using the density of the centrifuged sludge for each sample.

In addition to maintaining Pu concentrations below $2.6 \mathrm{~g} / \mathrm{L}$, to assure criticality safety, maintaining the ratio of neutron poisons $\mathrm{Al} / \mathrm{Pu}$ ratio $Z=910$ and/or $\mathrm{Fe} / \mathrm{Pu}$ ratio $Z=160$ is an independent means of assuring criticality safety. These criteria are met in the sludges retrieved from C-106.

${ }^{5}$ Measured from waste surface. 
WHC-SD-WM-TI-756, Rev. 0

This page intentionally left blank. 


\subsection{SUMMARY OF FINDINGS}

The various concerns related to chemistry-associated issues raised (Section 2.0 ) by the CR-SubTAP were reviewed, and detailed information addressing their concerns is provided in this document or in the reports and letters referenced herein. The reported information has also been provided to those responsible for:

- Modeling tank thermal behavior

- Producing the final safety assessment for retrieval of tank C-106

- Assuring tank C-106's criticality safety

- Assuring efficient operation of the sluicing process (to allow more finely tuned knowledge of tank C-106 and tank AY-102 waste behavior relative to the planned retrieval operation.

Much of the new data resulted from grab sampling tank C-106 and from compatibility testing of C-106 and AY-102 wastes. All of the chemistry-associated and other compatibility information compiled in this report strongly suggests that the sluicing of the contents, in accord with controls required by the Retrieval Safety Analysis (WHC 1996), will pose no unacceptable risk to workers, public safety, or the environment. In addition, it is expected that the sluicing operation will successfully resolve the high-heat safety issue.

The only significant anomaly found during the recent studies, the identification of "sludge oil" associated with C-106 solids (Sections 4.1 through 4.3), also poses no risk to the retrieval operations, but requires attention by the Pretreatment Program relative to unit operations associated with both liquid solids separation and sludge washing or leaching. 
WHC-SD-WM-TI-756, Rev. 0

This page intentionally left blank. 


\subsection{REFERENCES}

Agnew, 1995, Preliminary Estimation of C-106 Based on Tank History and Comparison to Measured Values and TRAC Predications, (external letter INC-14:93-sfa 168a to Stan Blacker, MACTEC, June 17), Los Alamos National Laboratory, Los Alamos, New Mexico.

Barton, 1996, Project W-320 Position Paper-Flammable Gas Issue, WHC-SD-W320-SP-002, Rev. 0, Westinghouse Hanford Company, Richland, Washington.

Castaing, B. A., 1995, 101-AY, 102-AY and 106-C Data Compendium, WHC-SD-WM-TI-578, Rev. 1, Westinghouse Hanford Company, Richland, Washington.

Cash, R. J., and H. Babad, 1996, Tank 241-C-106 Grab Sample - Technical Letter of Instruction, (internal letter 74E10-95-001 to R. A. Esch, R. D. Schreiber, and J. P. Harris III, January 4, 1996), Westinghouse Hanford Company, Richland, Washington.

Crawford, B. A., 1996, Sample Preparation of Tank 241-C-106 Samples and Testing and Testing for Compatibility with Tank 241-AY-102 Supernate, WHC-SD-WM-TP-430, Rev. 1, Westinghouse Hanford Company, Richland, Washington.

Dukelow, G. T., J. W. Hunt, H. Babad, and J. E Meacham, 1995, Tank Safety Screening Data Quality Objective, WHC-SD-WM-SP-004, Rev. 2, Westinghouse Hanford Company, Richland, Washington.

Fauske, H. K., 1996a, RSST and Tube Propagation Mineral Oil - NaNO, Tests, (letter to H. Babad, Westinghouse Hanford Company, April 9), Fauske and Associates, Inc., Burr Ridge, Illinois.

Fauske, H. K., 1996b, RSST Test with Stoichiometric Sodium Di(2-Ethylhexyl) Phosphate $\mathrm{Na}_{2} \mathrm{NO}_{3}$ Sample, (letter to $\mathrm{H}$. Babad et al., Westinghouse Hanford Company, April 24), Fauske and Associates, Inc., Burr Ridge, Illinois.

Fieser, L. F. and M. Fieser, 1967, Reagents for Organic Synthesis, Vol. 1, pp 191-192, John Wiley and Sons, Inc., New York, New York.

Fowler, K.D., 1991, Data Transmittal Package for 241-C-106, WHC-SD-RE-TI-205, Rev. OA, Westinghouse Hanford Company, Richland, Washington.

Fowler, K. D., 1995, Data Quality Objectives for Tank Farms Waste Compatibility Program, WHC-SD-WM-DQO-001, Rev. 1, Westinghouse Hanford Company, Richland, Washington. 
Hudson, B. H., 1995, Safety Assessment for Tank 241-C-106 Waste Retrievai, Project W-320, (letter to Professor M. S. Kazimi, Massachusetts Institute of Technology, November 28), Chairman, DOE-RL Chemical Reactions Sub-Panel of the Tanks Advisory Panel, Lindsborg, Kansas.

Jenks, C. H., E. Sonder, C. D. Bopp and J. R. Walton, 1975, "Reaction Products and Stored Energy Released from Irradiated Sodium Chloride by Dissolution and by Heating," Journal of Physical Chemistry, Vol. 79, No. 9, pp. 871-875.

Ogden, D. M., T. J. Bander, and B. A. Crea, 1996, Tank C-106 Heat Distribution and Post Sluicing Temperatures, (internal memorandum 74A50-96-BAC-006 to R. J. Cash, February 27), Westinghouse Hanford Company, Richland, Washington.

Ogden, D. M., and B. A. Crea, 1996, Resolution of Project W-320 Tier 2 Review Comments, (internal memorandum 74A50-96-BAC-003 to R. J. Cash, February 1), Westinghouse Hanford Company, Richland, Washington.

Pool, K. H, and R. M. Bean, 1994, Analysis of Liquid Samples From Hanford Waste Tank 241-C-106, PNL-9403, Pacific Northwest Laboratory, Richland, Washington.

Rogers, C. A., 1994, CSER 94-001: Criticality Safety of Single-Shell Waste Storage Tanks, WHC-SD-SQA-CSA-20363, Rev. 0, Westinghouse Hanford Company, Richland, Washington.

Scheele, R. D., M. E. Peterson, and J. M. Tingey, 1990, Revised Report on the Results of AY-102 Characterization, (letter report 9000855 to Distribution, February 12), Pacific Northwest Laboratory, Richland, Washington.

Schreiber, R. D., 1996, Tank 241-C-106 Grab Sampling and Analysis Plan, WHC-SD-WM-TSAP-080, Rev. 1, Westinghouse Hanford Company, Richland, Washington.

Sederburg, J. P., 1994, Chemical Compatibility of Tank Wastes in 241-C-106, 241-AY-101, and 241-AY-102, WHC-SD-WM-ES-290, Rev. 2, Westinghouse Hanford Company, Richland, Washington.

Waltar, A. E., 1996, Criticality Safety Assessment Of Tank 241-C-106 Remediation, WHC-SD-W320-CSA-001, Rev. 0, Westinghouse Hanford Company, Richland, Washington.

Weiss, R. L., 1987, Additional Analyses on Core Samples from Tanks 241-C-105 and 241-C-106, (internal memorandum 65453-87-050 to T. R. Pauly, April 14), Rockwell Hanford Operations, Richland, Washington. 
WHC, 1996, Safety Assessment for Tank 241-C-106 Waste Retrieval, Project W-320, WHC-SD-WM-SAD-024, Rev. 0, Westinghouse Hanford Company, Richland, Washington. 
WHC-SD-WM-TI-756, Rev. 0

This page intentionally left blank. 
APPENDIX A.1

CHEMISTRY ORIENTED RCRS RESULTING FROM THE

CR-SUBTAP REVIEW OF RETRIEVAL OF TANK C-106 
WHC-SD-WM-TI-756, Rev. 0

This page intentionally left blank.

A.1-2 


\section{APPENDIX A.1}

\section{CHEMISTRY-ORIENTED RCRS RESULTING FROM THE CR-SUBTAP REVIEW OF RETRIEVAL OF TANK C-106}

Excerpts from RCR Forms.

\begin{tabular}{|c|c|c|}
\hline Ien & Reveryers domment & Whoresponse \\
\hline 8. & $\begin{array}{l}\text { Evaluation of hazard (e.g., waste dry out } \\
\text { and overheating) consequences resulting } \\
\text { from sluicing shut down, or duration of } \\
\text { shut down, on C- } 106 \text { waste. }\end{array}$ & $\begin{array}{l}\text { Section } 2.4 .2 \text { includes a discussion of } \\
\text { the sluicing process, the consequences } \\
\text { of short- and long-term shutdowns, and } \\
\text { the measures instituted to prevent waste } \\
\text { dryout and overheating, based on Tank } \\
241-C-106 \text { Parametric Studies in } \\
\text { Support of Safety Alternative Process, } \\
\text { included in Appendix E, page E-1216. }\end{array}$ \\
\hline 9. & $\begin{array}{l}\text { Possible consequences and behavior of } \\
\text { waste remaining in C-106 after sluicing is } \\
\text { completed, e.g., waste dry out and } \\
\text { overheating. }\end{array}$ & $\begin{array}{l}\text { Remaining waste and its dryout have no } \\
\text { safety consequences, based on Internal } \\
\text { Memorandum 74A50-96-BAC-006, } \\
\text { included in Appendix E, Page } 1139 \text {. }\end{array}$ \\
\hline 12. & $\begin{array}{l}\text { Criteria and means for measuring } \\
\text { progress of waste transfer, i.e., whether } \\
\text { objectives of the project are being met. } \\
\text { We question whether C-106 waste can be } \\
\text { adequately understood (especially with } \\
\text { regard to distribution of heat-generating } \\
\text { materials) without the use of additional } \\
\text { core samples. Without an understanding } \\
\text { of high-heat materials distribution, any } \\
\text { basis for estimating heat source removal } \\
\text { rate or proportion is questionable. } \\
\text { Consequently, we suggest progress } \\
\text { determination must be based on } \\
\text { measurements of quantities such as } \\
\text { transfer waste radiation level, density, } \\
\text { flow rate, and/or on-line sampling of } \\
\text { transfer waste. We strongly suggest } \\
\text { planning and preparation for on-line } \\
\text { sampling. }\end{array}$ & $\begin{array}{l}\text { Operational controls and methods to } \\
\text { determine the progress (amounts of } \\
\text { transferred material) has been provided } \\
\text { in Sections } 2.4 .2 \text { and } 2.4 .3 \text {. This } \\
\text { represents a regular but intermittent } \\
\text { material balance during routine } \\
\text { operations. } \\
\text { The distribution of the heat-generating } \\
\text { materials is well enough understood } \\
\text { (Section } 1.2 \text { ) to allow for a successful } \\
\text { retrieval from C-106 without the need } \\
\text { for additional core samples and/or } \\
\text { in-line monitoring. }\end{array}$ \\
\hline
\end{tabular}


Excerpts from RCR Forms.

\begin{tabular}{|c|c|c|}
\hline 16ari & Merewers comnent & 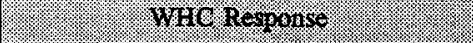 \\
\hline 21. & $\begin{array}{l}\text { C-106/AY- } 102 \text { waste compatibility } \\
\text { (including removal of supernate from } \\
\text { AY }-102 \text { and replacement with treated } \\
\text { water). The primary concern is creating } \\
\text { GRE conditions. We request a } \\
\text { presentation on this topic at a future } \\
\text { meeting. }\end{array}$ & $\begin{array}{l}\text { The "Chemical Compatibility of Tank } \\
\text { Wastes in 241-C-106, 241-AY-101, and } \\
241-A Y-102 \text { " WHC-SD-WM-ES-290, } \\
\text { Rev. 2, has been included in the SA, in } \\
\text { its entirety, in the Appendix E page } \\
931 \text {. This study assesses compatibility } \\
\text { of four sluicing fluids: } 241-\mathrm{AY}-101 \\
\text { supernatant, dilute non-complex } \\
\text { supernatant (such as } 241-\mathrm{AY}-102 \text { ), high } \\
\text { caustic (2.5 M NaOH solution), and } \\
\text { corrosion inhibited water. }\end{array}$ \\
\hline 22. & $\begin{array}{l}\text { Possible de-agglomeration of waste } \\
\text { particles and its effect on settling. This } \\
\text { concerns both clarification of sluicing } \\
\text { fluid and the potential for gas retention. }\end{array}$ & $\begin{array}{l}\text { The effects of de-agglomeration as it } \\
\text { relates to potential for gas retention in } \\
\text { tank AY-102 will be discussed by Dr. } \\
\text { H. Babad in a letter report centering on } \\
\text { several issues at the CRS meeting. } \\
\text { Settling as it relates to process control is } \\
\text { discussed in Section } 2.4 .2 .1 \text {, } \\
\text { (requirement to batch transfer material } \\
\text { from tank to tank because of failure of } \\
\text { material to readily settle in the receipt } \\
\text { tank). }\end{array}$ \\
\hline 23. & $\begin{array}{l}\text { Post-transfer "fluffing" of waste and its } \\
\text { effect on waste behavior (e.g., gas } \\
\text { retention). }\end{array}$ & $\begin{array}{l}\text { The impact of the fluffing factor on the } \\
\text { thermal performance is documented in } \\
\text { WHC-SD-WM-ER-534 Rev } 0 \text {, and has } \\
\text { been included on page E-1243 of } \\
\text { Appendix E. Controls on sludge depth } \\
\text { and tank temperature (Section } 6.2 .3 \text { ) } \\
\text { insure that temperature limits are not } \\
\text { exceeded. The impact of fluffing on the } \\
\text { GRE remains an open item (Section 6.4) } \\
\text { and must be resolved prior to start of } \\
\text { Operations. }\end{array}$ \\
\hline
\end{tabular}


Excerpts from RCR Forms.

\begin{tabular}{|c|c|c|}
\hline Ierm & Revaves obminem & WhO $\mathrm{Response}$ \\
\hline 25. & $\begin{array}{l}\text { Whether there is a criticality issue. We } \\
\text { strongly suggest a definitive criticality } \\
\text { analysis be performed for this specific } \\
\text { project before retrieval begins. }\end{array}$ & $\begin{array}{l}\text { Section } 4.3 .1 .2 \text { provides the summary } \\
\text { of the criticality analysis completed to } \\
\text { date. These analyses centered around } \\
\text { Pu concentration and poison ratios and } \\
\text { showed acceptable double contingency } \\
\text { protection against criticalities. } \\
\text { Recent concerns about possible Pu } \\
\text { separation and concentration } \\
\text { mechanisms have resulted in additional } \\
\text { limits being placed on all double shell } \\
\text { tanks ( } 25 \mathrm{Kg} \text { ). This remains an open } \\
\text { item, Section } 6.4 \\
\text { A further evaluation of the analysis is } \\
\text { being conducted by a Criticality Safety } \\
\text { Review Group made up of WHC, } \\
\text { PNNL, and DOE. The outcome of this } \\
\text { assessment will also be included in the } \\
\text { SA for review, when available. }\end{array}$ \\
\hline 28. & $\begin{array}{l}\text { Justification of data selected for use when } \\
\text { conflicting data exist (reconciliation of } \\
\text { conflicting data). }\end{array}$ & $\begin{array}{l}\text { All conflicting data have been } \\
\text { reconciled, with sufficient justification, } \\
\text { and reference material appended to } \\
\text { assure the reviewer of adequacy. }\end{array}$ \\
\hline 29. & $\begin{array}{l}\text { Identification and justification of all } \\
\text { assumptions used. }\end{array}$ & $\begin{array}{l}\text { All assumptions have been noted, and } \\
\text { justifications/background information } \\
\text { provided. }\end{array}$ \\
\hline 32. & $\begin{array}{l}\text { Where is the heat source? Do we have } \\
\text { reliable information about its magnitude? } \\
\text { What is the evidence that significant heat } \\
\text { is not generated in the hard pan? Are } \\
\text { temperature records available for the } \\
\text { period before the addition of Sr? We } \\
\text { suggest examination of existing data for } \\
\text { more detailed answers. We believe it is } \\
\text { important to decide, as soon as possible. } \\
\text { whether more core samples are needed to } \\
\text { answer these questions. }\end{array}$ & See responses to item 3 and 6 . \\
\hline
\end{tabular}


Excerpts from RCR Forms.

\begin{tabular}{|c|c|c|}
\hline $\operatorname{men}$ & Revrevers comment : & Who heroonse. \\
\hline 33. & $\begin{array}{l}\text { How can success of the retrieval } \\
\text { operation (removing } 74 \% \text { of the heating } \\
\text { materials, or all but } 40,000 \text { Btu/hr) be } \\
\text { measured? The initial answer was that } \\
\text { tank C-106 would be monitored after } \\
\text { sluicing. Can progress only be } \\
\text { determined after completion of the } \\
\text { project? Are there no plans for making } \\
\text { corrective measures if progress is not } \\
\text { satisfactory? We suggest provisions be } \\
\text { described (in detail) for monitoring } \\
\text { transfer line contents (radiation levels, } \\
\text { density, flow volume, etc.) and for } \\
\text { sampling of the waste transfer stream. In } \\
\text { addition, the best-possible description of } \\
\text { the contents of both tanks (before } \\
\text { sluicing) is needed. Direct. on-line } \\
\text { sampling of transferred waste would } \\
\text { appear to be the most satisfactory means } \\
\text { for monitoring success. }\end{array}$ & See response to item 12 . \\
\hline 34. & $\begin{array}{l}\text { Is there any stored energy in the waste } \\
\text { that may be violently released during } \\
\text { sluicing? Major emphasis was placed on } \\
\text { not observing such behavior in tanks } \\
\text { containing similar high heat waste. We } \\
\text { believe the answer must be based on data } \\
\text { from C-106. We therefore suggest } \\
\text { re-examination of existing data (including } \\
\text { original data references) to attempt } \\
\text { reconciliation of inconsistencies and } \\
\text { determine whether superheated regions } \\
\text { can be ruled out. If superheated regions } \\
\text { cannot be ruled out, we suggest } \\
\text { considering the potential effects of steam } \\
\text { flashing. A related concern is the } \\
\text { possibility of exceeding tank temperature } \\
\text { limits (in the absence of water addition) } \\
\text { due to hardpan left in C-106 after } \\
\text { sluicing. }\end{array}$ & $\begin{array}{l}\text { As described in the responses to items } \\
6,7 \text { and } 9 .\end{array}$ \\
\hline
\end{tabular}


Excerpts from RCR Forms.

\begin{tabular}{|c|c|c|}
\hline thent & Revievers comment & WHIC Response \\
\hline 35. & $\begin{array}{l}\text { Do the precipitated soluble materials } \\
\text { contain trapped electrons, lattice defects, } \\
\text { etc., which will liberate heat on } \\
\text { dissolution? We suggest determination of } \\
\text { bounding values for possible heat } \\
\text { liberation and conferring with BNL to } \\
\text { close the issue. }\end{array}$ & $\begin{array}{l}\text { BNL agreed to provide references and a } \\
\text { technical basis to support the concern } \\
\text { relating to a risk potential in the C-106 } \\
\text { system. None has been provided. In } \\
\text { addition, WHC/ CRS members have not } \\
\text { located any supporting references in the } \\
\text { literature for the C-106 case of waste } \\
\text { consisting of mostly amorphous, finely } \\
\text { divided particles in an aqueous medium. } \\
\text { This issue is considered closed. }\end{array}$ \\
\hline 36. & $\begin{array}{l}\text { Could there be a gas generation (release) } \\
\text { problem? We suggest developing an } \\
\text { upper bound for retained gas. Unless } \\
\text { safe upper limits for the volume of } \\
\text { retained gas can be demonstrated, we } \\
\text { suggest continuous monitoring of } \\
\text { flammable gas concentration in the dome } \\
\text { spaces of both C-106 and AY-102 } \\
\text { (consistent with flammable gas controls) } \\
\text { before during and after retrieval. } \\
\text { Related question: How much gas can be } \\
\text { tolerated in the transfer line? We suggest } \\
\text { bounding the possible gas content in the } \\
\text { transfer line and associated consequences. }\end{array}$ & $\begin{array}{l}\text { Continuous monitoring of flammable } \\
\text { gas concentration in the dome of both } \\
\text { C-106 and AY-102 before, during, and } \\
\text { after retrieval has been required } \\
\text { (Section } 6.1 .1 .15 \text { and } 6.1 .2 .15 \text { ) } \\
\text { Relative to gas transfer in the pipeline, } \\
\text { refer to the response given for item } 18 \text {. }\end{array}$ \\
\hline 37. & $\begin{array}{l}\text { What are the consequences involved in } \\
\text { the dissolution of precipitated salts in the } \\
\text { sludge? How much and what kinds of } \\
\text { toxic gas will be released? We suggest } \\
\text { inclusion of a detailed description of the } \\
\text { potential source term and corresponding } \\
\text { health and safety controls. }\end{array}$ & $\begin{array}{l}\text { This discussion will be included in the } \\
\text { letter report to be provided by Dr. } \\
\text { Babad (WHC) and appended to the SA, } \\
\text { when available. }\end{array}$ \\
\hline
\end{tabular}


Excerpts from RCR Forms.

\begin{tabular}{|c|c|c|}
\hline Tren & : Revievers Commert: & WHe Response \\
\hline 38. & $\begin{array}{l}\text { What are the consequences with respect to } \\
\text { criticality in using a sluicing fluid which } \\
\text { contains complexants capable of } \\
\text { segregating plutonium? We find the } \\
\text { answer given ("The requirements indicate } \\
\text { that the occurrence of a criticality } \\
\text { accident in the underground waste storage } \\
\text { tanks or transfer lines is incredible } \\
\text { because of the low concentration of fissile } \\
\text { materials present in the waste") not } \\
\text { acceptable, and suggest the answer should } \\
\text { be based on maximum possible Pu } \\
\text { concentration in the specific tanks } \\
\text { involved. This would require } \\
\text { documenting the Pu content and } \\
\text { prediction of maximum possible } \\
\text { concentration. Related questions were } \\
\text { raised by Kovach: What is the basis for } \\
\text { using a different criticality safety criteria } \\
\text { for this transfer than the standard } \\
\text { site-criticality safety basis? Tank C-106 } \\
\text { contains approximately } 96 \mathrm{~kg} \text { of Pu. Is it } \\
\text { expected that the proposed volume } \\
\text { retrieved (75\%) would remove only half } \\
\text { of the Pu? We strongly suggest a } \\
\text { definitive criticality analysis be performed } \\
\text { for this specific project before retrieval } \\
\text { begins. }\end{array}$ & See response to item 25 . \\
\hline
\end{tabular}


Excerpts from RCR Forms.

\begin{tabular}{|c|c|c|}
\hline Ment & Revieners Gominen & WHPS Respoist \\
\hline 39. & $\begin{array}{l}\text { What is the plan to preclude potential } \\
\text { precipitation during transfer and getting } \\
\text { pipes plugged? (Related questions: Will } \\
\text { there be a plugging problem during start } \\
\text { up or shut down? How would pipe } \\
\text { blockage be addressed? How does the } \\
\text { plan to avoid pipe plugging compare with } \\
\text { those of past practice [both successful and } \\
\text { unsuccessful?]) We suggest describing } \\
\text { expected gas release, particle size } \\
\text { distribution, etc. in the transfer line, } \\
\text { together with bounds for flow rate, } \\
\text { particle size, and solids loading, entrained } \\
\text { or released gas, etc. (to avoid pipe } \\
\text { blockage or damage) and associated } \\
\text { controls. If pipe blockage cannot be } \\
\text { ruled out, we suggest including a } \\
\text { description of contingency plans. }\end{array}$ & See responses to items 13,14 , and 18 . \\
\hline 40. & $\begin{array}{l}\text { What problems will emerge when the } \\
\text { saturated sluicing solution, produced in } \\
\text { the sluicing operation drops in } \\
\text { temperature in the transfer lines? Answer } \\
\text { given: "Dilute solutions based on using } \\
\text { buffered water should not create saturated } \\
\text { sluicing solutions" and "The analysis } \\
\text { determined that the temperature change } \\
\text { during transfer is less than two degrees } \\
\text { Centigrade which is minimum in respect } \\
\text { to the unsaturated region of the waste } \\
\text { during transfer." We suggest arguments } \\
\text { leading to these conclusions be included. }\end{array}$ & See response to item 17 . \\
\hline
\end{tabular}


Excerpts from RCR Forms.

\begin{tabular}{|c|c|c|}
\hline tein: & Revievers Cominent & WHC Response \\
\hline 41. & $\begin{array}{l}\text { What tests have been done to demonstrate } \\
\text { compatibility between the sluicing fluid } \\
\text { and the C-106 waste? (What will be done } \\
\text { to ensure compatibility?) While specific } \\
\text { actions were not agreed upon, the mixing } \\
\text { of actual waste samples would appear to } \\
\text { give the most reliable answer. We } \\
\text { request presentation of a detailed plan. } \\
\text { including important factors and specific } \\
\text { steps, te determine waste compatibility. }\end{array}$ & $\begin{array}{l}\text { Laboratory tests involved with mixing } \\
\text { samples with AY-102 supernate and } \\
\text { C-106 solids are in progress. The } \\
\text { results of these tests will be included in } \\
\text { the Babad letter report and appended to } \\
\text { the SA when available. }\end{array}$ \\
\hline 44. & $\begin{array}{l}\text { Is the assumption that dilution can be } \\
\text { used to prevent line plugging practical } \\
\text { when considered in the light of the mass } \\
\text { of soluble precipitated salts in the sludge? } \\
\text { (See answer to "10" above.) Is there a } \\
\text { significant amount of potential soluble } \\
\text { material than can dissolve and } \\
\text { re-precipitate? Whether the answer is yes } \\
\text { or no, we believe the answer should be } \\
\text { given in the document. }\end{array}$ & $\begin{array}{l}\text { This issue is considered resolved (see } \\
\text { Appendix E, page E-1155) }\end{array}$ \\
\hline
\end{tabular}




\begin{abstract}
APPENDIX A.2
TABULATION OF AVAILABLE DRAFT LABCORE DATA ON WIDE-MOUTH-BOTTLE-BASED GRAB SAMPLES OBTAINED FROM
\end{abstract} TANK C-106 IN THE SPRING OF 1996 
WHC-SD-WM-TI-756, Rev. 0

This page intentionally left blank. 


\section{APPENDIX A.2 \\ TABULATION OF AVAILABLE DRAFT LABCORE DATA ON WIDE MOUTH BOTTLE BASED GRAB SAMPLES OBTAINED FROM TANK C-106 IN THE SPRING OF 1996}

\section{Data Use Caveat:}

The data contained in this appendix are preliminary in nature and may be subject to change. This information has not yet undergone the required checks and quality reviews required by WHC laboratory characterization data reporting requirements. It is believed that data review and certification will not result in any changes to the conclusions reported in this document. The certified data acquired in the recent sludge sampling event will be added to the tank characterization database and ultimately will be reflected in the tank characterization report for tank C-106. 
WHC-SD-WM-TI-756, Rev. 0

This page intentionally left blank. 
Table A.2-1: Interim Results for Tank C-106 Grab Samples.

C-106 GRAB

RISER: 1

SEGMENT \#: 6C-96-10

SEGMENT PORTION: Centrifuged Solids (Grab Sample)

\begin{tabular}{|c|c|c|c|c|c|c|c|c|c|c|c|c|}
\hline Sample \# R & A \# & Analyte & Unit & \begin{tabular}{|c|} 
Standard \\
$\%$
\end{tabular} & Blank & Result & Duplicate & Average & $\begin{array}{c}\mathrm{RPD} \\
\%\end{array}$ & $\begin{array}{c}\text { Spk Rec } \\
\%\end{array}$ & Det Limit & $\begin{array}{c}\text { Count Em } \\
\%\end{array}$ \\
\hline S96T000558 & & Bulk Density of Sample & $\mathrm{g} / \mathrm{mL}$ & $n / a$ & $n / a$ & 1.760 & $n / a$ & $\mathrm{n} / \mathrm{a}$ & $\mathrm{n} / \mathrm{a}$ & $\mathrm{n} / \mathrm{a}$ & $5.000-01$ & $n / a$ \\
\hline S96T000558 & & $\begin{array}{l}\text { DSC Exotherm Dry } \\
\text { Calculated }\end{array}$ & Joules/g Dry & $n / a$ & $n / a$ & $0.00 e+00$ & $0.00 e+00$ & $0.00 e+00$ & 0.00 & $n / a$ & $n / a$ & $n / a$ \\
\hline S96T000558 & & $\begin{array}{l}\text { DSC Exotherm on Perkin } \\
\text { Elmer }\end{array}$ & Joules/g & 98.45 & $n / a$ & $0.00 e+00$ & $0.00 e+00$ & $0.00 e+00$ & 0.00 & $n / a$ & $n / a$ & $n / a$ \\
\hline S96T000558 & & $\begin{array}{l}\text { \% Water by TGA on Perkin } \\
\text { Elmer }\end{array}$ & $\%$ & 98.68 & $n / a$ & 11.71 & 14.00 & 12.86 & 17.8 & $n / a$ & $n / a$ & $n / a$ \\
\hline 596T000558 & & Volume \% Solids & $\%$ & $n / a$ & $n / a$ & 85.20 & $n / a$ & $n / a$ & $n / a$ & $n / a$ & $n / a$ & $\bar{n} / \mathrm{a}$ \\
\hline S96T000558 & & \% Water by Gravimetric & $\%$ & 98.14 & $n / a$ & 17.00 & 17.20 & 17.10 & 0.24 & $\bar{n} / \mathbf{a}$ & $1.00 \mathrm{e}-02$ & $n / a$ \\
\hline \multicolumn{13}{|c|}{ Control Sample: Control Sample } \\
\hline Sample \# R & $A \#$ & Analyte & Unit & $\begin{array}{c}\text { Standard } \\
\%\end{array}$ & Blank & Result & Duplicate & Average & $\begin{array}{c}\text { RPD } \\
\%\end{array}$ & $\begin{array}{c}\text { Spk Rec } \\
\%\end{array}$ & Det Limit & $\begin{array}{c}\text { Count Em } \\
\%\end{array}$ \\
\hline S96T000560 & & $\begin{array}{l}\text { DSC Exotherm on Perkin } \\
\text { Elmer }\end{array}$ & Joules/g & 98.45 & $n / a$ & $0.00 e+00$ & $0.00 e+00$ & $0.00 c+\infty$ & 0.00 & $\mathrm{n} / \mathrm{a}$ & $n / 4$ & $n / a$ \\
\hline S96T000560 & & $\begin{array}{l}\text { \% Water by TGA using } \\
\text { Mettlet }\end{array}$ & $\%$ & 102.2 & $\mathrm{n} / \mathbf{a}$ & 13.39 & 13.59 & 13.49 & 1.48 & $\mathrm{n} / \mathbf{a}$ & $n / 2$ & $n / 2$ \\
\hline S96T000561 & $F$ & Technetium-99 Liq. Scint. & $\mu \mathrm{Ci} / \mathrm{g}$ & 99.47 & $<3.58 \mathrm{e}-02$ & $<6.43 e-02$ & $<5.53 \mathrm{E}-2$ & $n / a$ & $n / a$ & $\mathrm{n} / \mathrm{a}$ & $6.40=-02$ & $6.35 \mathrm{E}+00$ \\
\hline \$96T000561 & $\mathbf{F}$ & Strontium-89/90 High Level & $\mu \mathrm{Ci} / g$ & 92.68 & $6.20 \mathrm{e}-02$ & $1.74 e+02$ & 152.0 & 163.0 & 13.5 & $n / a$ & $4.800-02$ & $6.80 \mathrm{E}-01$ \\
\hline S96T000561 & $\mathbf{F}$ & $\begin{array}{l}\text { Pu-239/240 by TRU-SPEC } \\
\text { Resin }\end{array}$ & $\mu \mathrm{Ci} / \mathrm{g}$ & 94.49 & $<5.300$ & $<6.20 c-02$ & $<4.67 \mathrm{E}-2$ & $n / a$ & $n / a$ & $\mathrm{n} / \mathrm{a}$ & 6.20002 & $1.00 \mathrm{E}+02$ \\
\hline$\$ 96 T 000561$ & $\mathbf{F}$ & Cobalt-60 by GEA & $\mu \mathrm{Ci} / g$ & 98.05 & $<4.73 \mathrm{e}-01$ & $<2.05 \mathrm{e}-01$ & $<1.88 \mathrm{e}-1$ & $n / a$ & $n / a$ & $\mathrm{n} / \mathrm{a}$ & $2.050-01$ & $n / a$ \\
\hline
\end{tabular}


Table A.2-1: Interim Results for Tank C-106 Grab Samples.

C-106 GRAB

\begin{tabular}{|c|c|c|c|c|c|c|c|c|c|c|c|c|}
\hline \multicolumn{13}{|c|}{ Control Sample: Control Sample (Continued) } \\
\hline Sample \# R & $A \#$ & Analyte & Unit & $\begin{array}{c}\text { Standard } \\
\%\end{array}$ & Blank & Result & Duplicate & Average & $\begin{array}{c}\text { RPD } \\
\approx\end{array}$ & $\underset{\%}{\text { Spk Rec }}$ & Det Limit & $\begin{array}{c}\text { Count Err } \\
\%\end{array}$ \\
\hline S96T000561 & $F$ & Cesium-137 by GEA & $\mu \mathrm{Ci} / g$ & 98.56 & $<9.17 \mathrm{e}-01$ & $1.98 e+02$ & 170.0 & 183.8 & 15.2 & $n / 2$ & $n / a$ & 1.01 \\
\hline \$96T000561 & $\mathbf{F}$ & Am-241 by Extraction & $\mu \mathrm{Ci} / \mathrm{g}$ & 105.5 & $<4,43 \mathrm{e}-02$ & $4.26 e-01$ & $3.62 e-01$ & $3.94 \mathrm{e}-01$ & 16.2 & $n / a$ & $6.80 \mathrm{e}-02$ & $3.95 \mathrm{E}+00$ \\
\hline S96T000561 & $\mathrm{F}$ & Alpha of Digested Solid & $\mu \mathrm{Ci} / g$ & 118.0 & $<5.57 \mathrm{e}-02$ & 1.560 & 1.150 & 1.355 & 30.3 & 107.8 & $1.32 \mathrm{e}-01$ & $2.00 \mathrm{E}+01$ \\
\hline \multicolumn{13}{|c|}{ Decanted Supernate (Liquid Grab Sludge): Decanted Supernate (Liquid Grab Sludge) } \\
\hline S96T000559 & & Specific Gravity & Sp.G. & 101.1 & $n / a$ & 1.156 & 1.150 & 1.153 & 0.52 & $n / a$ & $1.00 \mathrm{e}-03$ & $\mathbf{n} / \mathbf{a}$ \\
\hline \$96T000559 & & \% Water by Gravimetric & $\%$ & 98.65 & $n / a$ & 79.30 & 79.30 & 79.30 & 0.00 & $n / \mathbf{a}$ & $1.00 \mathrm{e}-02$ & $n / \mathbf{a}$ \\
\hline \multicolumn{13}{|c|}{ Filtered Centrifuged Solids: Filtered Centrifuged Solids } \\
\hline \$96T000567 & & DSC Exotherm using Mettler & Joules/g & 99.82 & $\mathrm{n} / \mathrm{a}$ & 69.70 & 94.70 & 82.20 & 30.4 & $\mathrm{n} / \mathrm{a}$ & $n / a$ & $n / a$ \\
\hline \$96T000567 & & $\begin{array}{l}\text { DSC Exotherm Dry } \\
\text { Caiculated }\end{array}$ & Joules/g Dry & $n / a$ & $\mathrm{n} / \mathrm{a}$ & 93.87 & 127.5 & 110.7 & 30.4 & $n / \mathbf{a}$ & $n / a$ & $n / a$ \\
\hline $596 \mathrm{~T} 000567$ & & $\begin{array}{l}\text { \% Water by TGA using } \\
\text { Mettler }\end{array}$ & $\%$ & 101.7 & $\mathbf{n} / \mathbf{a}$ & 26.22 & 25.27 & 25.74 & 3.69 & $n / a$ & $n / a$ & $n / a$ \\
\hline S96T000568 & & TIC by Acid/Coulometry & $\mu \mathrm{g} / \mathrm{g}$ & 97.84 & $8.00 \mathrm{e}-01$ & $2.93 e+04$ & $2.56 e+04$ & $2.74 e+04$ & 13.5 & 100.0 & 5.000 & $n / a$ \\
\hline S96T000568 & & $\begin{array}{l}\text { TOC by Persulfatel } \\
\text { Coulometry }\end{array}$ & $\mu \mathrm{g} / \mathrm{g}$ & 92.03 & 3.100 & $2.04 c+04$ & $2.49 \mathrm{c}+04$ & $2.26 e+04$ & 19.9 & 87.90 & 40.00 & $n / a$ \\
\hline $596 \mathrm{~T} 000569$ & & $\%$ Water by Gravimetric & $\%$ & 98.14 & $\mathbf{n} / \mathbf{a}$ & 26.30 & 27.30 & 26.80 & 1.37 & $\mathrm{n} / \mathbf{a}$ & $1.00 \mathrm{e}-02$ & $n / a$ \\
\hline S96T000570 & & pH on SST Samples & $\mathrm{pH}$ & $n / \mathbf{a}$ & $n / a$ & 10.56 & 10.54 & 10.55 & 0.19 & $n / a$ & $1.000-02$ & $n / a$ \\
\hline S96T000571 & $\mathbf{F}$ & Technetium-99 Liq. Scint. & $\mu \mathrm{Ci} / \mathrm{g}$ & 99.47 & $<3.58 \mathrm{e}-02$ & $<2.260-002$ & $<2.74 \mathrm{E}-2$ & $n / \mathbf{a}$ & $n / a$ & $n / a$ & $2.30 \mathrm{e}-02$ & $6.16 \mathrm{E}+\infty$ \\
\hline S96T000571 & $\mathrm{F}$ & Strontium-89/90 High Level & $\mu \mathrm{Ci} / \mathrm{B}$ & 101.6 & $1.17 e-01$ & $1.86 e+02$ & 517.0 & 351.5 & 94.2 & $n / a$ & $4.40 c-02$ & $5.50 \mathrm{E}-01$ \\
\hline S96T000571 & $\mathbf{F}$ & $\begin{array}{l}\text { Pu-239/240 by TRU-SPEC } \\
\text { Resin }\end{array}$ & $\mu \mathrm{Ci} / \mathrm{g}$ & 94.49 & $<5.300$ & $<2.17 e-02$ & $<2.79 \mathrm{E}-2$ & $n / a$ & $n / a$ & $\mathrm{n} / \mathbf{a}$ & $2.200-02$ & $1.00 \mathrm{E}+02$ \\
\hline \$96T000571 & $\mathbf{F}$ & Cobalt -60 by GEA & $\mu \mathrm{Ci} / \mathrm{g}$ & 96.66 & $<1.52 \mathrm{e}-01$ & $<1.28 \mathrm{e}-01$ & $3.51 \mathrm{e}-01$ & $n / a$ & $n / a$ & $n / a$ & $1.28 \mathrm{e}-01$ & $n / a$ \\
\hline S96T000571 & $\mathbf{F}$ & Cesium-137 by GEA & $\mu \mathrm{Ci} / g$ & 96.08 & $<2.04 \mathrm{e}-01$ & $2.05 e+02$ & 531.0 & 367.8 & 88.6 & $n / a$ & $n / a$ & 0.640 \\
\hline
\end{tabular}


Table A.2-1: Interim Results for Tank C-106 Grab Samples.

C-106 GRAB

Filtered Centrifuged Solids: Filtered Centrifuged Solids (Continued)

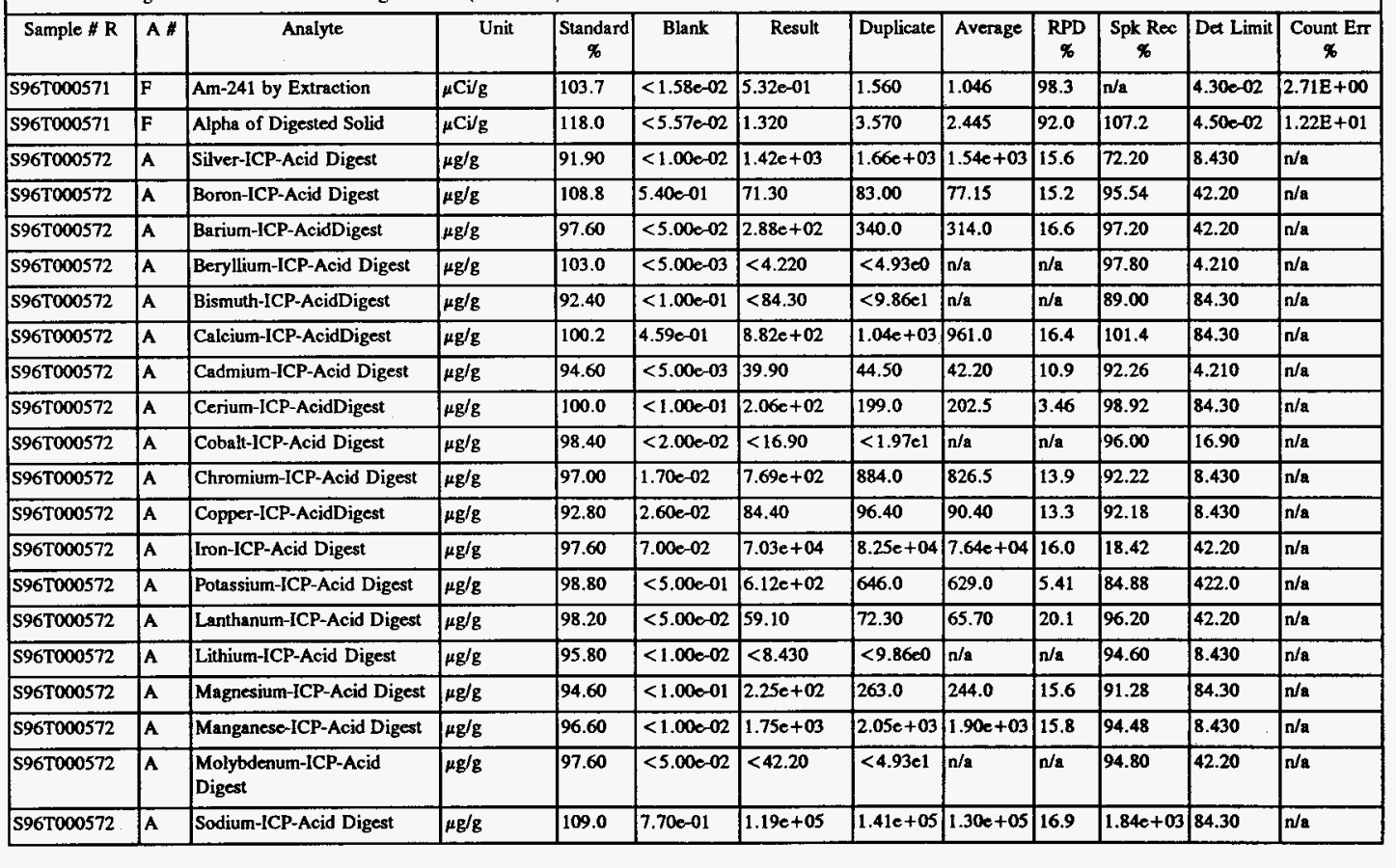


Table A.2-1: Interim Results for Tank C-106 Grab Samples.

C-106 GRAB

Filtered Centrifuged Solids: Filtered Centrifuged Solids (Continued)

\begin{tabular}{|c|c|c|c|c|c|c|c|c|c|c|c|c|}
\hline Sample \# R & $A \#$ & Aralyte & Unit & $\begin{array}{c}\text { Standard } \\
\%\end{array}$ & Blank & Result & Duplicate & Average & $\begin{array}{c}\text { RPD } \\
\%\end{array}$ & $\begin{array}{c}\text { Spk Rec } \\
\%\end{array}$ & Det Limit & $\begin{array}{c}\text { Count Ert } \\
\%\end{array}$ \\
\hline S96T000572 & A & Neodymium-ICP-Acid Digest & $\mu \mathrm{g} / \mathrm{g}$ & 98.00 & $<1.00 e-01$ & $1.53 e+02$ & 170.0 & 161.5 & 10.5 & 96.66 & 84.30 & $n / \mathbf{a}$ \\
\hline S96T000572 & A & Nickel-ICP-Acid Digest & $\mu \mathrm{g} / \mathrm{g}$ & 97.20 & $<2,00 \mathrm{e}-02$ & $6.53 \mathrm{e}+02$ & 755.0 & 704.0 & 14.5 & 88.94 & 16.90 & $n / a$ \\
\hline S96T000572 & A & Phosphorus-ICP-Acid Digest & $\mu \mathrm{g} / \mathrm{g}$ & 99.80 & $<2.00=-01$ & $2.22 e+03$ & $2.60 e+03$ & $2.41 e+03$ & 15.8 & 122.7 & 169.0 & $\mathbf{n} / \mathbf{a}$ \\
\hline S96T000572 & A & Lead-ICP-Acid Digest & $\mu g / g$ & 91.60 & $<1.00 e-01$ & $2.55 e+03$ & $2.97 c+03$ & $2.76 e+03$ & 15.2 & 82.02 & 84.30 & $n / a$ \\
\hline S96T000572 & A & Sulfur-ICP-Acid Digest & $\mu \mathrm{g} / \mathrm{g}$ & 95.60 & $<1.00 \mathrm{e}-01$ & $1.13 e+03$ & $1.32 e+03$ & $1.22 e+03$ & 15.5 & 93.96 & 84.30 & $\mathrm{n} / \mathbf{a}$ \\
\hline S96T000572 & A & Antimony-ICP-Acid Digest & $\mu g / g$ & 96.60 & $<6.00 \mathrm{e}-02$ & 95.40 & $<5.91 \mathrm{e} 1$ & $\mathbf{n} / \mathbf{a}$ & $n / a$ & 83.88 & 50.60 & $\mathbf{n} / \mathbf{a}$ \\
\hline S96T000572 & A & Selenium-ICP-Acid Digest & $\mu g / g$ & 97.80 & $<1.00 e-01$ & $<84.30$ & $<9.86 \mathrm{el}$ & $n / a$ & $n / a$ & 98.80 & 84.30 & $\mathbf{n} / \mathbf{a}$ \\
\hline$\$ 96 T 000572$ & A & Silicon-ICP-Acid Digest & $\mu \mathrm{g} / \mathrm{g}$ & 135.2 & $2.27 \mathrm{e}-01$ & $2.27 e+04$ & $2.66 e+04$ & $2.46 c+04$ & 15.8 & $n / a$ & 42.20 & $n / a$ \\
\hline $596 \mathrm{~T} 000572$ & A & Samarium-ICP-Acid Digest & $\mu \mathrm{g} / \mathrm{g}$ & 99.80 & $<1.00 e-01$ & $<84.30$ & $<9.86 \mathrm{cl}$ & $n / a$ & $n / a$ & 99.00 & 84.30 & $n / a$ \\
\hline S96T000572 & A & Strontium-ICP-Acid Digest & $\mu \mathrm{g} / \mathrm{g}$ & 97.00 & $<1.00 e-02$ & 17.70 & 20.40 & 19.05 & 14.2 & 95.70 & 8.430 & $n / a$ \\
\hline 5967000572 & A & Titanium-ICP-Acid Digest & $\mu \mathrm{g} / \mathrm{g}$ & 91.60 & $<1.00 \mathrm{e}-02$ & $1.25 e+02$ & 147.0 & 136.0 & 16.2 & 89.62 & 8.430 & $n / a$ \\
\hline S96T000572 & A & Uranium-ICP-AcidDigest & $\mu \mathrm{g} / \mathrm{g}$ & 94.40 & $<5.00 \mathrm{e}-01$ & $7.07 e+02$ & 890.0 & 798.5 & 22.9 & 104.1 & 422.0 & $n / a$ \\
\hline S96T000572 & A & Vanadium-ICP-Acid Digest & $\mu \mathrm{g} / \mathrm{g}$ & 96.40 & $<5.00 \mathrm{e}-02$ & $<42.20$ & $<4.93 \mathrm{el}$ & $n / a$ & $n / a$ & 95.40 & 42.20 & $n / a$ \\
\hline \$96T000572 & A & Zinc-ICP-Acid Digest & $\mu \mathrm{g} / \mathrm{g}$ & 92.60 & $2.50 \mathrm{e}-02$ & 40.30 & 44.60 & 42.45 & 10.1 & 91.22 & 8.430 & $n / a$ \\
\hline S96T000572 & A & Zirconium-ICP-Acid Digest & $\mu \mathrm{g} / \mathrm{g}$ & 104.2 & $<1.00 c-02$ & $7.55 e+02$ & 890.0 & 822.5 & 16.4 & 180.4 & 8.430 & $n / a$ \\
\hline S96T000574 & $\mathbf{w}$ & $\begin{array}{l}\text { Fluoride-IC-Dionex } \\
4000 \mathrm{i} / 4500\end{array}$ & $\mu \mathrm{g} / \mathrm{g}$ & 96.10 & $<1.30 \mathrm{e}-02$ & $1.94 e+02$ & 195.0 & 194.7 & 0.51 & 100.8 & 55.12 & $n / a$ \\
\hline $596 T 000574$ & $\mathbf{w}$ & $\begin{array}{l}\text { Chloride-IC-Dionex } \\
4000 \mathrm{i} / 4500\end{array}$ & $\mu g / g$ & 99.11 & 3.30e-02 & $1.47 e+02$ & 133.0 & 140.0 & 10.0 & 95.06 & 72.07 & $n / a$ \\
\hline S96T000574 & $\mathbf{w}$ & Nitrite-IC-Dionex $4000 \mathrm{i} / 4500$ & $\mu \mathrm{g} / \mathrm{g}$ & 97.74 & $<1.07 \mathrm{e}-01$ & $1.04 e+04$ & $1.03 e+04$ & $1.03 e+04$ & 0.97 & 107.5 & 453.6 & $n / a$ \\
\hline $596 \mathrm{T000574}$ & $w$ & $\begin{array}{l}\text { Nitrate by IC-Dionex } \\
4000 \mathrm{i} / 4500\end{array}$ & $\mu \mathrm{g} / \mathrm{g}$ & 97.72 & $<1.40 \mathrm{e}-01$ & $1.83 e+03$ & 978.0 & $1.41 e+03$ & 60.7 & 93.81 & 593.2 & $n / 8$ \\
\hline
\end{tabular}


Table A.2-1: Interim Results for Tank C-106 Grab Samples.

C-106 GRAB

Filtered Centrifuged Solids: Filtered Centrifuged Solids (Continuad)

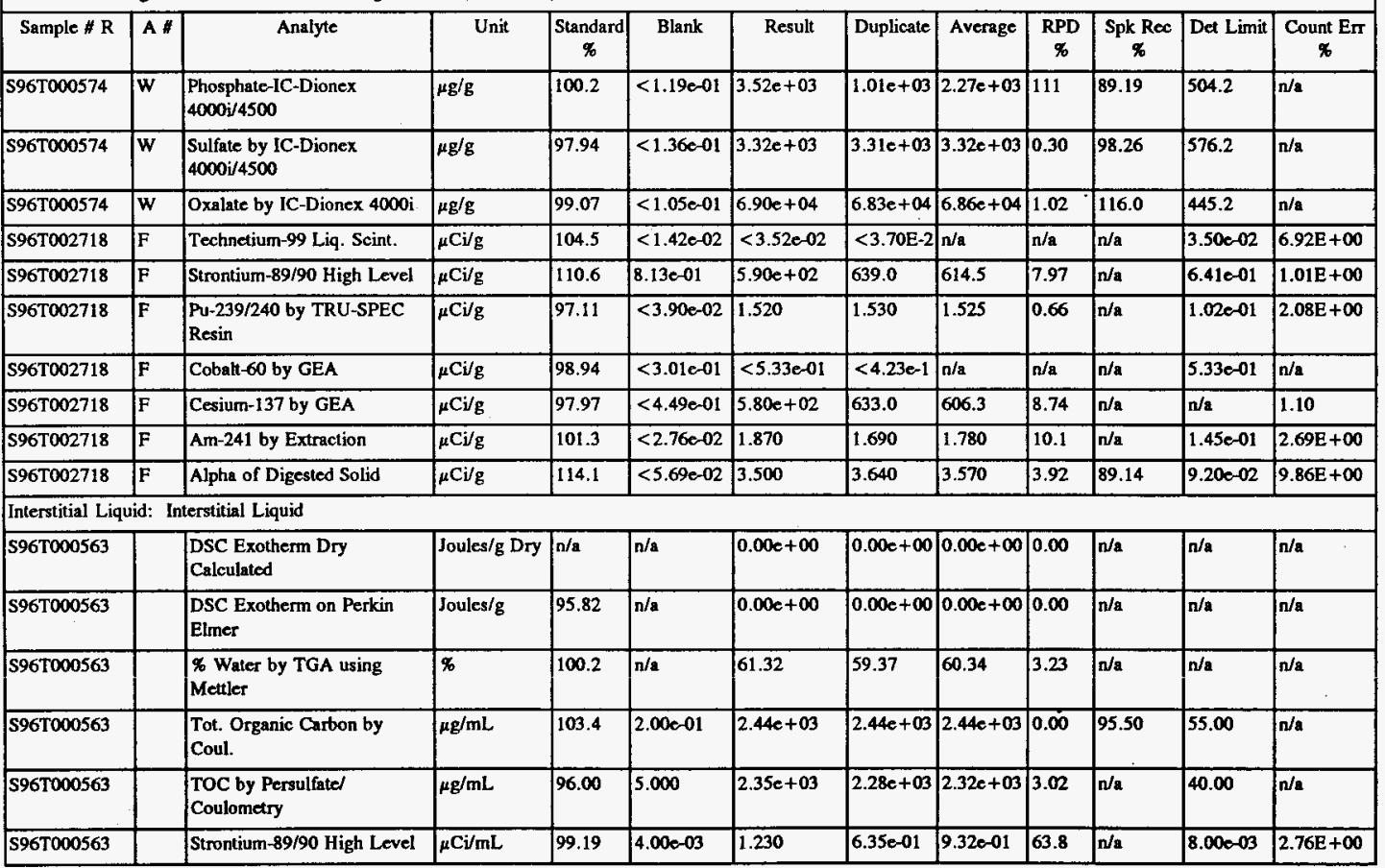




\begin{tabular}{|c|c|c|c|c|c|c|c|c|c|c|c|c|}
\hline \multicolumn{13}{|c|}{$\begin{array}{l}\text { Table A.2-1: Interim Results for Tank C-106 Grab Samples. } \\
\text { C-106 GRAB }\end{array}$} \\
\hline \multicolumn{13}{|c|}{ Interstitial Liquid: Interstitial Liquid (Continued) } \\
\hline Sample \# R & A \# & Analyte & Unit & \begin{tabular}{|c|} 
Standard \\
$\%$
\end{tabular} & Blank & Result & Duplicate & Average & $\underset{\%}{\text { RPD }}$ & $\begin{array}{c}\text { Spk Rec } \\
\%\end{array}$ & Det Limit & $\underset{\%}{\text { Count En }}$ \\
\hline S96T000563 & & $\begin{array}{l}\text { Pu-239/240 by TRU-SPEC } \\
\text { Resin }\end{array}$ & $\mu \mathrm{Ci} / \mathrm{mL}$ & 93.44 & $<3.56 \mathrm{e}-03$ & $8.12 e-01$ & $8.33 \mathrm{e}-01$ & $8.23 e-01$ & 2.55 & $n / a$ & $3.80 \mathrm{e}-02$ & $1.59 \mathrm{E}+00$ \\
\hline S96T000563 & D & Silver-ICP-Acid Dil. & $\mu \mathrm{g} / \mathrm{mL}$ & 97.60 & $<1.00 \mathrm{e}-02$ & $<4.010$ & $<4.0100$ & n/a & $\mathrm{n} / \mathrm{a}$ & 92.80 & 4.010 & $n / a$ \\
\hline $596 \mathrm{~T} 000563$ & D & Aluminum-ICP-Acid Dil. & $\mu \mathrm{g} / \mathrm{mL}$ & 96.60 & $<5.00 \mathrm{e}-02$ & $<20.10$ & $<2.01 \mathrm{el}$ & $\mathrm{n} / \mathrm{a}$ & $\mathbf{n} / \mathbf{a}$ & 92.80 & 20.10 & $n / a$ \\
\hline 596T000563 & D & Arsenic-ICP-Acid Dil. & $\mu \mathrm{g} / \mathrm{mL}$ & 101.0 & $<1.00 \mathrm{c}-01$ & $<40.10$ & $<4.01 \mathrm{el}$ & $n / a$ & $\mathbf{n} / \mathbf{a}$ & 103.8 & 40.10 & $n / a$ \\
\hline S96T000563 & D & Boron-ICP-Acid Dil. & $\mu \mathrm{g} / \mathrm{mL}$ & 101.8 & $<5.00 \mathrm{e}-02$ & $<20.10$ & $<2.01 \mathrm{el}$ & $\mathrm{n} / \mathrm{a}$ & $\mathrm{n} / \mathbf{a}$ & 102.5 & 20.10 & $\mathrm{n} / \mathrm{a}$ \\
\hline S96T000563 & D & Barium-ICP-Acid Dil. & $\mu \mathrm{g} / \mathrm{mL}$ & 99.40 & $<5.00 \mathrm{e}-02$ & $<20.10$ & $<2.01 \mathrm{e} 1$ & $\mathrm{n} / \mathrm{a}$ & $\mathrm{n} / \mathrm{a}$ & 99.00 & 20.10 & $n / a$ \\
\hline S96T000563 & D & Beryllium-ICP-Acid Dil. & $\mu \mathrm{g} / \mathrm{mL}$ & 103.8 & $<5.000-03$ & $<2.000$ & $<2.0000$ & $n / a$ & $\mathbf{n} / \mathbf{a}$ & 101.8 & 2.000 & $n / 8$ \\
\hline $596 \mathrm{~T} 000563$ & D & Bismuth-ICP-Acid Dil. & $\mu \mathrm{g} / \mathrm{mL}$ & 99.80 & $<1.000-01$ & $<40.10$ & $<4.01 \mathrm{el}$ & $n / a$ & $n / a$ & 95.50 & 40.10 & $n / a$ \\
\hline S96T000563 & D & Calcium-ICP-Acid Dil. & $\mu \mathrm{g} / \mathrm{mL}$ & 99.60 & $<1.00 \mathrm{e}-01$ & $<40.10$ & $<4.01 \mathrm{el}$ & $\mathrm{n} / \mathrm{a}$ & $\mathrm{n} / \mathrm{a}$ & 99.00 & 40.10 & $\mathrm{n} / \mathbf{a}$ \\
\hline $596 \mathrm{~T} 000563$ & D & Cadmium-ICP-Acid Dil. & $\mu \mathrm{g} / \mathrm{mL}$ & 100.8 & $<5.00 \mathrm{e}-03$ & $<2.000$ & $<2.0000$ & $\mathrm{n} / \mathrm{a}$ & $\mathrm{n} / \mathrm{a}$ & 98.00 & 2.000 & $n / a$ \\
\hline S96T000563 & D & Cerium-ICP-Acid Dil. & $\mu \mathrm{g} / \mathrm{mL}$ & 100.4 & $<1.00 \mathrm{e}-01$ & $<40.10$ & $<4.01 \mathrm{el}$ & $n / a$ & $\mathrm{n} / \mathrm{a}$ & 96.50 & 40.10 & $n / a$ \\
\hline S96T000563 & D & Cobalt-ICP-Acid Dil. & $\mu \mathrm{g} / \mathrm{mL}$ & 100.2 & $<2.00 \mathrm{e}-02$ & $<8.020$ & $<8.0200$ & $n / 2$ & $n / a$ & 97.00 & 8.020 & $n / a$ \\
\hline S96T000563 & D & Chromium-ICP-Acid Dil. & $\mu \mathrm{g} / \mathrm{mL}$ & 100.2 & $<1.000-02$ & $<4.010$ & $<4.01 \mathrm{e0}$ & $\mathrm{n} / \mathrm{a}$ & n/a & 98.50 & 4.010 & $n / a$ \\
\hline S96T000563 & D & Copper-ICP-Acid Dil. & $\mu \mathrm{g} / \mathrm{mL}$ & 100.6 & $<1.00 e-02$ & $<4.010$ & $<4.0100$ & $n / a$ & $n / a$ & 99.80 & 4.010 & $n / a$ \\
\hline S96T000563 & D & Iron-ICP-Acid Dil. & $\mu \mathrm{g} / \mathrm{mL}$ & 103.4 & $<5.00 \mathrm{e}-02$ & $<20.10$ & $<2.01 \mathrm{e} 1$ & $n / a$ & $n / a$ & 105.2 & 20.10 & $n / a$ \\
\hline S96T000563 & $D$ & Potassium-ICP-Acid Dil. & $\overline{\mu g} / \mathrm{mL}$ & 97.20 & $<5.00 c-01$ & $5.48 \mathrm{e}+02$ & 564.0 & 556.0 & 2.88 & 96.40 & 200.0 & $n / a$ \\
\hline S96T000563 & $D$ & Lanthanum-ICP-Acid Dil. & $\mu \mathrm{g} / \mathrm{mL}$ & 100.8 & $<5.00 \mathrm{e}-02$ & $<20.10$ & $<2.01 \mathrm{e} 1$ & $n / a$ & $\mathrm{n} / \mathrm{a}$ & 101.0 & 20.10 & $n / a$ \\
\hline S96T000563 & $D$ & Lithium-ICP-Acid Dil. & $\mu \mathrm{g} / \mathrm{mL}$ & 97.00 & $<1.00 \mathrm{c}-02$ & $<4.010$ & $<4.0100$ & $n / a$ & $n / a$ & 92.00 & 4.010 & $\pi / \mathbf{a}$ \\
\hline $596 \mathrm{T000563}$ & D & Magnesium-ICP-Acid Dil. & $\mu \mathrm{g} / \mathrm{mL}$ & 96.80 & $<1.000-01$ & $<40.10$ & $<4.0101$ & $\mathrm{n} / \mathrm{a}$ & $n / a$ & 93.80 & 40.10 & $n / a$ \\
\hline$\$ 96 \mathrm{T000563}$ & D & Manganese-ICP-Acid Dil. & $\mu \mathrm{g} / \mathrm{mL}$ & 100.2 & $<1.00=-02$ & $<4.010$ & $<4.0120$ & $n / a$ & $n / a$ & 99.30 & 4.010 & $\mathrm{n} / \mathbf{2}$ \\
\hline $596 \mathrm{~T} 000563$ & D & Molybdenum-ICP-Acid Dil. & $\mu \mathrm{g} / \mathrm{mL}$ & 99.20 & $<5.00<-02$ & 21.30 & $<2.01 \mathrm{e} 1$ & $\mathrm{n} / \mathrm{a}$ & $\mathrm{n} / \mathrm{a}$ & 96.70 & 20.10 & $\mathrm{n} / \mathbf{a}$ \\
\hline
\end{tabular}


Table A.2-1: Interim Results for Tank C-106 Grab Samples.

C-106 GRAB

\begin{tabular}{|c|c|c|c|c|c|c|c|c|c|c|c|c|}
\hline \multicolumn{13}{|c|}{ Interstitial Liquid: Interstitial Liquid (Continued) } \\
\hline Sample \# R & $A$ \# & Analyte & Unit & $\begin{array}{c}\text { Standard } \\
\%\end{array}$ & Blank & Result & Duplicate & Average & $\begin{array}{c}\text { RPD } \\
\%\end{array}$ & $\begin{array}{c}\text { Spk Rec } \\
\mathscr{\%}_{0}\end{array}$ & Det Limit & $\begin{array}{c}\text { Count Err } \\
\%\end{array}$ \\
\hline$\$ 96 T 000563$ & D & Sodium-ICP-Acid Dil. & $\mu \mathrm{g} / \mathrm{mL}$ & 96.60 & $<1.00 \mathrm{e}-01$ & $1.03 e+05$ & $1.01 \mathrm{e}+05$ & $1.02 e+05$ & 1.96 & $n / a$ & 40.10 & $n / a$ \\
\hline 5967000563 & D & Neodymium-ICP-Acid Dil. & $\mu \mathrm{g} / \mathrm{mL}$ & 105.8 & $<1.00=-01$ & $<40.10$ & $<4.01 \mathrm{el}$ & $\mathbf{n} / \mathbf{a}$ & $\mathbf{n} / \mathbf{a}$ & 105.5 & 40.10 & $n / a$ \\
\hline \$96T000563 & $\mathrm{D}$ & Nickel-ICP-Acid Dil. & $\mu \mathrm{g} / \mathrm{mL}$ & 100.4 & $<2.00<-02$ & 13.70 & 13.50 & 13.60 & 1.47 & 98.60 & 8.020 & $n / a$ \\
\hline 5967000563 & D & Phosphorus-ICP-Acid Dil. & $\mu \mathrm{g} / \mathrm{mL}$ & 108.8 & $<2.000-01$ & $3.71 \mathrm{e}+02$ & 375.0 & 373.0 & 1.07 & 115.0 & 80.20 & $n / a$ \\
\hline \$96T000563 & D & Lead-ICP-Acid Dil. & $\mu \mathrm{g} / \mathrm{mL}$ & 100.6 & $<1.000-01$ & $<40.10$ & $<4.01 \mathrm{el}$ & $n / a$ & $n / a$ & 99.50 & 40.10 & $n / a$ \\
\hline$\$ 967000563$ & D & Sulfur-ICP-Acid Dil. & $\mu \mathrm{g} / \mathrm{mL}$ & 98.20 & $<1.00 c-01$ & $2.48 e+03$ & $2.50 e+03 \mid$ & $2.49 e+03$ & 0.80 & 82.70 & 40.10 & $n / a$ \\
\hline$\$ 96 T 000563$ & $D$ & Antimony-ICP-Acid Dil. & $\mu \mathrm{g} / \mathrm{mL}$ & 94.60 & $<6.00 \mathrm{e}-02$ & $<24.10$ & $<2.41 \mathrm{el}$ & $n / \mathbf{a}$ & $n / a$ & 90.80 & 24.10 & $\mathbf{n} / \mathbf{a}$ \\
\hline S96T000563 & D & Selenium-ICP-Acid Dil. & $\mu \mathrm{g} / \mathrm{mL}$ & 102.6 & $<1.00=01$ & $<40.10$ & $<4.01 \mathrm{el}$ & $\mathrm{n} / \mathbf{a}$ & $n / a$ & 110.0 & 40.10 & $n / a$ \\
\hline $596 \mathrm{~T} 000563$ & D & Silicon-ICP-Acid Dil. & $\mu \mathrm{g} / \mathrm{mL}$ & 95.20 & $<5.00=-02$ & 25.80 & 26.90 & 26.35 & 4.17 & 95.10 & 20.10 & $n / a$ \\
\hline 5967000563 & $D$ & Samarium-ICP-Acid Dil. & $\mu \mathrm{g} / \mathrm{mL}$ & 101.0 & $<1.000-01$ & $<40.10$ & $<4.01 \mathrm{el}$ & $n / \mathbf{a}$ & $n / a$ & 102.0 & 40.10 & $\mathbf{n} / \mathbf{a}$ \\
\hline$\$ 96 \mathrm{~T} 000563$ & D & Strontium-ICP-Acid Dil. & $\mu \mathrm{g} / \mathrm{mL}$ & 99.40 & $<1.00 e-02$ & $<4.010$ & $<4.01 € 0$ & $n / a$ & $\mathbf{n} / \mathbf{a}$ & 99.30 & 4.010 & $n / \mathbf{a}$ \\
\hline S96T000563 & D & Titanium-ICP-Acid Dil. & $\mu \mathrm{g} / \mathrm{mL}$ & 96.60 & $<1.00 e-02$ & $<4.010$ & $<4.0100$ & $n / a$ & $\mathbf{n} / \mathbf{a}$ & 96.00 & 4.010 & $\mathbf{n} / \mathbf{a}$ \\
\hline \$96T000563 & D & Thallium-ICP-Acid Dil. & $\mu \mathrm{g} / \mathrm{mL}$ & 95.00 & $<2.00 c-01$ & $<80.20$ & $<8.02 \mathrm{el}$ & $n / a$ & $n / a$ & 85.80 & 80.20 & $\mathbf{n} / \mathbf{a}$ \\
\hline $596 T 000563$ & D & Uranium-ICP-Acid Dil. & $\mu \mathrm{g} / \mathrm{mL}$ & 98.50 & $<5.00 \mathrm{e}-01$ & $1.56 e+03$ & $1.57 e+03$ & $1.56 \mathrm{e}+03$ & 0.64 & 102.3 & 200.0 & $\mathbf{a} / \mathbf{a}$ \\
\hline$\$ 96 \mathrm{~T} 000563$ & D & Vanadium-ICP-Acid Dil. & $\mu \mathrm{g} / \mathrm{mL}$ & 102.0 & $<5.00 c-02$ & $<20.10$ & $<2.01 \mathrm{el}$ & $n / a$ & $\mathbf{n} / \mathbf{a}$ & 100.0 & 20.10 & $n / a$ \\
\hline$\$ 96 \mathrm{~T} 000563$ & D & Zinc-ICP-Acid Dil. & $\mu \mathrm{g} / \mathrm{mL}$ & 100.6 & $<1.00 \mathrm{e}-02$ & $<4.010$ & $<4.01 \mathrm{co}$ & $n / a$ & $\mathbf{n} / \mathbf{a}$ & 97.50 & 4.010 & $\mathbf{n} / \mathbf{a}$ \\
\hline S96T000563 & D & Zirconium-ICP-Acid Dil. & $\mu \mathrm{g} / \mathrm{mL}$ & 99.80 & $<1.00 \mathrm{e}-02$ & $3.36 e+02$ & 336.0 & 336.0 & 0.00 & 100.6 & 4.010 & $n / a$ \\
\hline S96T000563 & & $\begin{array}{l}\text { Fluoride-IC-Dionex } \\
4000 \mathrm{i} / 4500\end{array}$ & $\mu \mathrm{g} / \mathrm{mL}$ & 95,42 & $<1.30 c-02$ & $2.36 e+02$ & 230.0 & 232.8 & 2.58 & 108.5 & 27.57 & $n / a$ \\
\hline S96T000563 & & $\begin{array}{l}\text { Chloride-IC-Dionex } \\
4000 \mathrm{i} / 4500\end{array}$ & $\mu \mathrm{g} / \mathrm{mL}$ & 90.38 & $5.55 \mathrm{e}-01$ & $3.04 e+02$ & 326.0 & 315.1 & 6.98 & 91.65 & 36.06 & $\mathbf{n} / \mathbf{a}$ \\
\hline $596 \mathrm{~T} 000563$ & & Nitrite-IC-Dionex $4000 \mathrm{i} / 4500$ & $\mu \mathrm{g} / \mathrm{mL}$ & 97.95 & $<1.07 e-01$ & $2.91 e+04$ & $2.83 e+04$ & $2.87 e+04$ & 2.79 & 102.6 & 226.9 & $\mathbf{n} / \mathbf{a}$ \\
\hline S96T000563 & & Nitrate-IC-Dionex $4000 \mathrm{i} / 4500$ & $\mu \mathrm{g} / \mathrm{mL}$ & 93.97 & $2.05 e-01$ & $1.17 e+03$ & $1.14 e+03$ & $1.15 c+03$ & 2.60 & 94.46 & 296.9 & $\mathbf{n} / \mathbf{a}$ \\
\hline
\end{tabular}




\begin{tabular}{|c|c|c|c|c|c|c|c|c|c|c|c|c|}
\hline \multicolumn{13}{|c|}{ Interstitial Liquid: Interstitial Liquid (Continued) } \\
\hline Sample f R & $A=$ & Anglyte & Init & & Plont & Penth & Dolio & Av?mor & & & $\mathrm{D}$ & \\
\hline Sample A $\mathrm{K}$ & A $\boldsymbol{F}$ & Allatyle & Jiat & $\%$ & Blank & Resurt & Dupicate & Average & $\$$ & $\begin{array}{c}3 \text { pik Rec } \\
\%\end{array}$ & Det Limit & $\%$ \\
\hline S96T000563 & & $\begin{array}{l}\text { Phosphate-IC-Dionex } \\
4000 \mathrm{i} / 4500\end{array}$ & $\mu \mathrm{g} / \mathrm{mL}$ & 96.89 & $<1.19 \mathrm{e}-01$ & $6.49 e+02$ & 609.0 & 629.0 & 6.36 & 97.80 & 252.2 & $n / \mathbf{a}$ \\
\hline S96T000563 & & $\begin{array}{l}\text { Sulfate by IC-Dionex } \\
4000 \mathrm{i} / 4500\end{array}$ & $\mu \mathrm{g} / \mathrm{mL}$ & 95.56 & $<1.36 \mathrm{e}-01$ & $7.76 e+03$ & $7.61 e+03$ & $7.69 e+03$ & 1.95 & 98.89 & 288.2 & $\mathbf{n} / \mathbf{a}$ \\
\hline S96T000563 & & Oxalate by IC-Dionex $4000 \mathrm{i}$ & $\mu \mathrm{g} / \mathrm{mL}$ & 95.09 & $<1.05 e-01$ & $3.08 e+03$ & $3.09 e+03$ & $3.09 e+03$ & 0.32 & 98.43 & 222.7 & $\sqrt{n / 2}$ \\
\hline S96T000563 & & Cobalt -60 by GEA & $\mu \mathrm{Ci} / \mathrm{mL}$ & 96.11 & $<6.53 \mathrm{e}-04$ & $<8.45 \mathrm{e}-03$ & $1.24 \mathrm{e}-02$ & $n / \mathbf{a}$ & $n / a$ & $n / \mathbf{a}$ & $8.000-03$ & $\pi / \mathfrak{a}$ \\
\hline S96T000563 & & Cesium- 137 by GEA & $\mu \mathrm{Ci} / \mathrm{mL}$ & 95.94 & $<4.940-04$ & $1.54 c+02$ & 153.0 & 153.5 & 0.65 & $\mathbf{n} / \mathbf{a}$ & $\mathbf{n} / \mathbf{a}$ & 0.200 \\
\hline \multicolumn{13}{|c|}{ Potential Organic Layer: Potential Organic Layer } \\
\hline S96T001567 & & DSC Exotherm using Mettler & Joules/g & 113.9 & $\mathbf{n} / \mathbf{a}$ & $2.15 e+02$ & 142.4 & 178.8 & 40.7 & $n / a$ & $\mathbf{n} / \mathbf{a}$ & $\overline{n / a}$ \\
\hline S96T001567 & & $\begin{array}{l}\text { DSC Exotherm Dry } \\
\text { Calculated }\end{array}$ & Joules/g Dry & $n / a$ & $n / \mathbf{a}$ & $7.06 e+02$ & 467.7 & 587.0 & 40.7 & $n / a$ & $n / \mathbf{a}$ & $\mathrm{n} / \mathbf{a}$ \\
\hline S96T001567 & & $\begin{array}{l}\text { \% Water by TGA using } \\
\text { Mettler }\end{array}$ & $\%$ & 103.7 & $n / \mathbf{a}$ & 71.58 & 67.52 & 69.55 & 5.84 & $n / a$ & $\mathbf{n} / \mathbf{a}$ & $\mathbf{n} / \mathbf{a}$ \\
\hline S96T001567 & & $\begin{array}{l}\text { TOC by Persulfatel } \\
\text { Coulometry }\end{array}$ & $\mu \mathrm{g} / \mathrm{mL}$ & 94.03 & 3.000 & $3.08 \mathrm{e}+04$ & $3.48 e+04$ & $3.28 e+04$ & 12.2 & $n / a$ & 40.00 & $n / \mathbf{a}$ \\
\hline 5967002634 & & $\begin{array}{l}\text { Pu-239/240 by TRU-SPEC } \\
\text { Resin }\end{array}$ & $\mu \mathrm{Ci} / \mathrm{g}$ & 99.21 & $<3.10 e-02$ & $6.41 \mathrm{e}-01$ & $6.31 \mathrm{e}-01$ & $6.36 \mathrm{e}-01$ & 1.57 & $n / a$ & $4.600-02$ & $2.00 \mathrm{E}+\infty$ \\
\hline S96T002634 & & Pu-238 by lon Exchange & $\mu \mathrm{Ci} / \mathrm{g}$ & $n / a$ & $<3.100-02$ & $2.000-01$ & $2.010-01$ & 2.01001 & 0.50 & $\mathbf{n} / \mathbf{a}$ & $4.600-02$ & $2.78 \mathrm{E}+\infty$ \\
\hline
\end{tabular}


Table A.2-1: Interim Results for Tank C-106 Grab Samples.

C-106 GRAB

\begin{tabular}{|c|c|c|c|c|c|c|c|c|c|c|c|c|}
\hline SEGMENT \#: & $6 \mathrm{C}-9$ & $5-17$ & & & & & & & & & & \\
\hline \multicolumn{13}{|c|}{ SEGMENT PORTION: Field Blank } \\
\hline Sample / R & $A=$ & Analyte & Unit & $\begin{array}{l}\text { Standard } \\
\%\end{array}$ & Blank & Result & Duplicate & Average & $\begin{array}{l}\text { RPD } \\
\%\end{array}$ & $\begin{array}{l}\text { Spk Rec } \\
\%\end{array}$ & Det Limit & $\begin{array}{l}\text { Count Er } \\
\%\end{array}$ \\
\hline S96T000855 & & DSC Exotherm using Mettler & Joules/g & 94.55 & $n / a$ & $0.00 e+\infty$ & $0.00 \mathrm{e}+\infty$ & $0.00 e+\infty$ & 0.00 & $n / a$ & $n / a$ & $n / a$ \\
\hline S96T000855 & & $\begin{array}{l}\text { Ammonia by ISE-Std } \\
\text { Additions }\end{array}$ & $\mu \mathrm{g} / \mathrm{mL}$ & 106.8 & $5.80 \mathrm{e}-02$ & $<5.000$ & $<5.00$ & $n / a$ & $n / a$ & 104.0 & 5.000 & $n / a$ \\
\hline S96T000855 & & pH Direct & $\mathrm{pH}$ & $n / \mathfrak{a}$ & $n / a$ & 8.282 & 8.239 & 8.261 & 0.52 & $n / a$ & $1.000-02$ & $\mathbf{n} / \mathbf{a}$ \\
\hline S96T000855 & & Specific Gravity & Sp.G. & 102.1 & $\mathrm{n} / \mathrm{a}$ & $9.75 e-01$ & $9.74 e-01$ & $9.74 e-01$ & 0.10 & $n / a$ & $1.00 c-03$ & $n / a$ \\
\hline S96T000855 & & $\begin{array}{l}\% \text { Water by TGA using } \\
\text { Mettler }\end{array}$ & $\%$ & 101.9 & $n / a$ & $1.00 c+02$ & 99.85 & 100.2 & 0.65 & $n / a$ & $n / a$ & $n / a$ \\
\hline S96TO00855 & & Tot. Inorg. Carbon by Coul. & $\mu \mathrm{g} / \mathrm{mL}$ & 97.17 & $<5.000$ & 8.000 & 9.500 & 8.750 & 17.1 & $n / a$ & 5.000 & \\
\hline \$96T000855 & & $\begin{array}{l}\text { Tot. Organic Carbon by } \\
\text { Coul. }\end{array}$ & $\mu \mathrm{g} / \mathrm{mL}$ & 103.0 & $9.00 \mathrm{e}-01$ & 17.10 & 14.30 & 15.70 & 17.8 & 96.70 & 5.500 & $\mathbf{n} / \mathbf{a}$ \\
\hline S96T000855 & & $\begin{array}{l}\text { TOC by Persulfatel } \\
\text { Coulometry }\end{array}$ & $\mu \mathrm{g} / \mathrm{mL}$ & 93.03 & 1.600 & $<40.00$ & $<40$ & $n / a$ & $\mathbf{n} / \mathbf{a}$ & $n / a$ & 40.00 & $\mathbf{n} / \mathbf{a}$ \\
\hline S96T000855 & & \% Water by Gravimetric & $\%$ & 98.82 & $n / a$ & $1.00 c+02$ & 100.0 & 100.0 & 0.00 & n/a & $1.000-02$ & $n / a$ \\
\hline S96T000855 & & Technetium-99 Liq. Scint. & $\mu \mathrm{Ci} / \mathrm{mL}$ & 102.6 & $<3.72 \mathrm{e}-05$ & $<3.560-05$ & $3.84 c-05$ & $\mathrm{n} / \mathrm{a}$ & $n / a$ & $n / 2$ & $3.560-05$ & $7.04 \mathrm{E}+00$ \\
\hline S96T000855 & & Strontium-89/90 High Level & $\mu \mathrm{Ci} / \mathrm{mL}$ & 104.1 & $8.78 e-07$ & $1.79 e-02$ & $1.79 \mathrm{e}-02$ & $1.79 \mathrm{e}-02$ & 0.00 & $n / a$ & $9.32=-07$ & $2.26 \mathrm{E}-01$ \\
\hline S96T000855 & & $\begin{array}{l}\text { Pu-239/240 by TRU-SPEC } \\
\text { Resin }\end{array}$ & $\mu \mathrm{Ci} / \mathrm{mL}$ & 109.4 & $<3.660-05$ & $1.64 c-05$ & $1.63 e-05$ & 1.63005 & 0.61 & $n / a$ & $3.660-06$ & 4.0 \\
\hline S96T000855 & D & Silver-ICP-Acid Dil. & $\mu \mathrm{g} / \mathrm{mL}$ & 99.20 & $<1.00 c-02$ & $<1.00 \mathrm{c}-02$ & $<1.00 e-2$ & $n / a$ & $n / a$ & 81.50 & $1.00 \mathrm{e}-02$ & $n / a$ \\
\hline S96T000855 & D & Aluminum-ICP-Acid Dil. & $\mu \mathrm{g} / \mathrm{mL}$ & 97.80 & $<5.00=-02$ & $2.82 e-01$ & $2.62 e-01$ & $2.72 \mathrm{e}-01$ & 7.35 & 98.30 & $5.000-02$ & $n / a$ \\
\hline S96T000855 & D & Arsenic-ICP-Acid Dil. & $\mu \mathrm{g} / \mathrm{mL}$ & 101.6 & $<1.000-01$ & $<1.000-01$ & $<1,00 \mathrm{e}-1$ & $n / a$ & $n / a$ & 100.0 & $1.000-01$ & $n / a$ \\
\hline S96T000855 & D & Boron-ICP-Acid Dil. & $\mu \mathrm{g} / \mathrm{mL}$ & 101.4 & $<5.00=-02$ & $<5.00 c-02$ & $<5.000-2$ & $\mathbf{n} / \mathbf{a}$ & $n / a$ & 99.20 & $5.000-02$ & $\mathbf{n} / \mathbf{a}$ \\
\hline S96T000855 & $D$ & Barium-ICP-Acid Dil. & $\mu \mathrm{g} / \mathrm{mL}$ & 98.40 & $<5.00 \mathrm{e}-02$ & $<5.00 \mathrm{e}-02$ & $<5.00 \mathrm{e}-2$ & $n / a$ & $n / a$ & 96.90 & $5.000-02$ & $n / a$ \\
\hline
\end{tabular}




\begin{tabular}{|c|c|c|c|c|c|c|c|c|c|c|c|c|}
\hline$\pi / \mathrm{u}$ & $10-000$ & $0 z: s_{6}$ & $89 \varepsilon$ & $10-x=c$ & $10-\infty 0 z \varepsilon$ & to-xzE $\varepsilon$ & $10-200^{\circ} \mid>$ & $00 \% 66$ & TW/Ant & 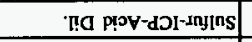 & a & S58000L96S \\
\hline$u / u$ & $10-000$ & $s .101$ & $\mathbf{x} / \mathrm{u}$ & v/u & $I-900^{\circ} I>$ & $10-0001>$ & $10-900^{-1} 1>$ & 0.101 & $\mathrm{~T} \omega / \mathrm{an}$ & 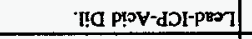 & a & $558000 \perp 96 \mathrm{~S}$ \\
\hline $\mathrm{z} / \mathrm{u}$ & $10-200 \%$ & $\angle 101$ & $80^{\circ} \mathrm{t}$ & s\&zZ & $061^{\circ} z$ & $082 z$ & $10-2002>$ & +001 & $\mathrm{~T} w / 3 n$ & "I!d p!PV-dכI-snuoudsoud & a & $558000 \pm .96 \mathrm{~S}$ \\
\hline $\mathbf{x / u}$ & $20-000 z$ & 0586 & $\mathrm{~B} / \mathrm{u}$ & $\mathrm{z} / \mathrm{u}$ & $z-\infty, 00$ & $20-200 \% z>$ & $z 0^{-}-000^{\circ} z>$ & $+\infty 01$ & 7w/ân & Ta piov-dDI- & a & SS8000L $96 \mathrm{~S}$ \\
\hline $\mathbf{e} / \mathbf{u}$ & $10-200 \%$ & 069 & $\mathbf{z} / \mathbf{u}$ & $\mathbf{z} / \mathbf{u}$ & $I-\infty 00 \cdot I>$ & $10-000 \mathrm{I}>$ & $10-001>$ & 00001 & $\mathrm{Tu} / \mathrm{ant}$ & 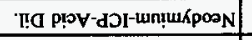 & a & \$58000.L96S \\
\hline$\nabla / 4$ & $10-200 \div$ & 2.001 & 60.1 & 0081 & $0 \varepsilon^{\prime} 8 \mathrm{i}$ & 0581 & $10-200.1>$ & $0+\angle 6$ & רш/3nt & 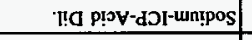 & a) & \$S80001.96S \\
\hline $8 \pi$ & $20-000$ & 0586 & $8 / \mathrm{u}$ & $\pm / \mathrm{u}$ & $2-\infty 00.5>$ & $20-0005>$ & $20-200^{\circ} 5>$ & $z \cdot 101$ & $\mathrm{Tut} / \mathrm{s} n$ & 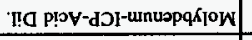 & a & S58000196S \\
\hline $\mathrm{z} / \mathrm{u}$ & $20-200 \div$ & 0586 & 960 & $20-250 \mathrm{I}$ & $20-250.1$ & $200+0 \mathrm{I}$ & 2000013 & 8.001 & $7 w / 3 \pi$ & 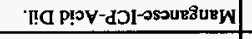 & a & S58000.1.965 \\
\hline 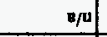 & $10-200 \%$ & $0 I+6$ & $\tau \cdot \varepsilon \mathrm{l}$ & $10-86 t$ & $10-202: 1$ & IOOLE'] & $10^{-}-200^{\circ} I>$ & $08: 26$ & 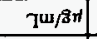 & 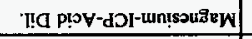 & a & $\$ 58000 \perp 96 S$ \\
\hline $\mathrm{ey}, \mathrm{u}$ & $20000 \%$ & 0696 & $\mathbf{v} / \mathrm{u}$ & $\mathrm{R} / \mathrm{u}$ & $2-2001>$ & $20-200 \div 1>$ & $20-200^{-} \tau>$ & $0 * 86$ & $\mathrm{Tus} / \mathrm{Ar}$ & 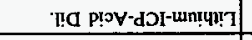 & a & S58000L96S \\
\hline $\mathrm{z} / \mathrm{u}$ & $20000 \% s$ & $0<\angle 6$ & $\nabla / \mathrm{u}$ & $\mathrm{m} / \mathrm{w}$ & $2-200$ s $>$ & $20-200 s>$ & $20-200.5>$ & $0 z \cdot 66$ & $\mathrm{Tw/3n}$ & 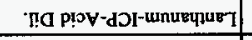 & a) & $558000196 \mathrm{~S}$ \\
\hline $\mathrm{B} / \mathrm{u}$ & $10-2005$ & 8. EZI & $\mathrm{B} / \mathrm{u}$ & $8 / \mathbf{u}$ & $1-300$ 's $>$ & $10-000^{\circ} s>$ & $10^{-200} \mathrm{~s}>$ & F.10I & $\mathrm{T} \omega / 3 n$ & 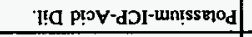 & d] & \$\$8000196S \\
\hline $\mathrm{s} / \mathrm{u}$ & $20-2005$ & $0 \varepsilon^{\prime} 86$ & $\mathrm{z} / \mathrm{u}$ & $\mathrm{x} / \mathrm{u}$ & $z-\infty 00, s>$ & $20-50 z: 5$ & $20-000 s>$ & O.10I & $7^{\omega / 3 / 3 n}$ & 'I!G p!oy-dDI-UaII & a & SS8000.L96S \\
\hline $8 / \mathrm{u}$ & $20-200 \mathrm{I}$ & 02.66 & $\mathrm{z} / \mathrm{u}$ & $\mathbf{z} / \mathbf{u}$ & $2-200: I>$ & $20-2001>$ & $20-0001>$ & $09: 66$ & $\mathbf{T w / 3 \pi}$ & I!q plov-dDI-saddoo & a & S58000.196S \\
\hline $\mathrm{B} / \mathrm{u}$ & $20-200 \%$ & 0586 & $\mathrm{z} / \mathrm{u}$ & $\mathrm{v} / \mathrm{u}$ & $\tau-200$ I> & $20-200,1>$ & $20-000$ I $>$ & 5.101 & qw/3nt & 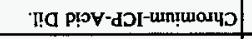 & a) & \$58000.L96S \\
\hline $\mathrm{s} / \mathrm{u}$ & $z 0-900 z$ & $0 z^{\prime} 66$ & $\mathrm{~s} / \mathrm{u}$ & $\mathrm{B} / \mathrm{u}$ & $z-200 z>$ & $20-200 \tau>$ & $20-200 \cdot 2>$ & $\tau \cdot 101$ & $\mathrm{~T} w / 3 \pi$ & 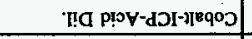 & d] & S58000L $196 \mathrm{~S}$ \\
\hline $\mathrm{z} / \mathrm{u}$ & $10-000$ & $09 \div 6$ & $\mathrm{p} / \mathrm{u}$ & $8 / 0$ & $1-\infty 00 i \mathrm{i}$ & $10-0001>$ & $10-000.1>$ & $02 \cdot 66$ & $T w / 3 n$ & I!d ploy-dDI-unusos & a) & S58000.L96S \\
\hline $\mathrm{B} / \mathrm{u}$ & $\varepsilon 0-200^{\circ} \mathrm{S}$ & 0586 & $\mathrm{~s} / \mathrm{u}$ & $8 / \mathrm{u}$ & $E-\infty 00^{\circ} S>$ & $\varepsilon 0-200 \subseteq>$ & $50-2000^{\circ}>$ & 7.001 & $T w / 8 n$ & I!d P!ov-dכI-un!щupro & a) & S૬8000I.96S \\
\hline $\mathrm{y}, \mathrm{u}$ & $10-000 \mathrm{I}$ & 06.86 & 16.1 & S08.9 & $0 \circ \angle \cdot 9$ & $0<8^{\circ}$ & $10-0001>$ & 08.86 & $7 \mathrm{w} / \mathrm{s} n$ & 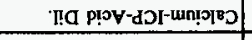 & a) & \$\$8000L96S \\
\hline $\mathrm{z} / \mathrm{v}$ & $10-800$ & $0 z \cdot 96$ & $\mathrm{z} / \mathrm{u}$ & $\mathrm{z} / \mathrm{u}$ & $t \rightarrow 00 t>$ & $10-\infty 00: I>$ & $10-0001>$ & 08.86 & $\mathrm{~T}^{\mathrm{w} / \mathrm{an} / \mathrm{H}}$ & I!d p!oV-dכI-4mums!g & a & $558000 \mathrm{~L} 96 \mathrm{~S}$ \\
\hline $8 / 4$ & $\varepsilon 0-500$ 's & s.10I & $\mathrm{z} / \mathrm{u}$ & $\mathrm{z} / \mathrm{u}$ & $\varepsilon-\infty 00$ 's> & $\varepsilon 0-200 \mathrm{~s}>$ & $50-200-\varsigma>$ & +201 & $\eta^{m / a n}$ & 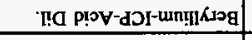 & a) & $\$ \$ 8000 \perp 96 \mathrm{~S}$ \\
\hline $\begin{array}{c}\text { \% } \\
\text { עg funos }\end{array}$ & นุแับ & $\infty^{\%}$ & $\begin{array}{c}\% \\
\text { add }\end{array}$ & 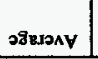 & भซषọ!dna & unsoy & Ү्रणघ[8 & $\begin{array}{c}\text { \% } \\
\text { puspums }\end{array}$ & џִu & 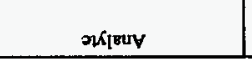 & $\# \mathbf{v}$ & y \# गฺdurs \\
\hline \multicolumn{13}{|c|}{ 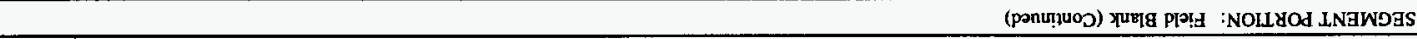 } \\
\hline & & & & •sə]du & & כ y ye & $\begin{array}{l}\text { d } 901^{-} \\
\text {IOJ stins }\end{array}$ & مبإ & $: I-Z$ & IqEI & & \\
\hline
\end{tabular}




\begin{tabular}{|c|c|c|c|c|c|c|c|c|c|c|c|c|}
\hline \multicolumn{13}{|c|}{ SEGMENT PORTION： Field Blank (Continued) } \\
\hline Sample \# R & A* & Analyte & Unit & $\begin{array}{c}\text { Standard } \\
\%\end{array}$ & Blank & Result & Duplicate & Average & $\underset{\%}{\text { RPD }}$ & $\begin{array}{c}\text { Spk Rec } \\
\%\end{array}$ & Det Limit & $\underset{\%}{\text { Count Err }}$ \\
\hline S96T000855 & D & Antimony-ICP-Acid Dil. & $\mu \mathrm{g} / \mathrm{mL}$ & 94.20 & $<6.00 \mathrm{e}-02$ & $<6.000-02$ & $<6.00 \mathrm{e}-2$ & $n / a$ & $n / a$ & 90.80 & $6.00 \mathrm{e}-02$ & $\mathbf{n} / \mathbf{a}$ \\
\hline S96T000855 & D & Selenium-ICP-Acid Dil. & $\mu \mathrm{g} / \mathrm{mL}$ & 98.20 & $<1.00 \mathrm{e}-01$ & $<1.00 \mathrm{e}-01$ & $<1.00 e-1$ & $\mathrm{n} / \mathbf{a}$ & $\mathbf{n} / \mathbf{a}$ & 97.70 & $1.00 x-01$ & $n / \mathbf{a}$ \\
\hline S96T000855 & D & Silicon-ICP-Acid Dil. & $\mu \mathrm{g} / \mathrm{mL}$ & 95.00 & $<5.00 \mathrm{e}-02$ & 7.36e-01 & 7.17e-01 & $7.26 \mathrm{e}-01$ & 2.62 & 95.70 & $5.00 e-02$ & $\mathrm{n} / \mathbf{a}$ \\
\hline S96T000855 & D & Samarium-ICP-Acid Dil. & $\mu \mathrm{g} / \mathrm{mL}$ & 99.00 & $<1.00 c-01$ & $<1.00 \mathrm{c}-01$ & $<1.00 c-1$ & $n / a$ & $\mathbf{n} / \mathbf{a}$ & 95.40 & $1.000-01$ & $\mathrm{n} / \mathbf{a}$ \\
\hline $596 \mathrm{~T} 000855$ & D & Strontium-ICP-Acid Dil. & $\mu \mathrm{g} / \mathrm{mL}$ & 98.20 & $<1.00 \mathrm{e}-02$ & $<1.00 \mathrm{e}-02$ & $<1.00 \mathrm{e}-2$ & $\mathrm{n} / \mathbf{a}$ & $\mathbf{n} / \mathbf{a}$ & 96.90 & $1.000-02$ & $n / \mathbf{a}$ \\
\hline S96T000855 & D & Titanium-ICP-Acid Dil. & $\mu \mathrm{g} / \mathrm{mL}$ & 98.20 & $<1.00 \mathrm{e}-02$ & $<1.00 \mathrm{e}-02$ & $<1.00 \mathrm{e}-2$ & $n / a$ & $\mathrm{n} / \mathbf{a}$ & 96.20 & $1.000-02$ & $n / \mathbf{a}$ \\
\hline $596 \mathrm{~T} 000855$ & D & Thallium-ICP-Acid Dil. & $\mu \mathrm{g} / \mathrm{mL}$ & 97.00 & $<2.00 \mathrm{e}-01$ & $<2.00 \mathrm{e}-01$ & $<2.00 \mathrm{e}-1$ & $n / a$ & $\mathbf{n} / \mathbf{a}$ & 86.90 & $2.000-01$ & $\mathrm{n} / \mathrm{a}$ \\
\hline S96T000855 & $\mathrm{D}$ & Uranium-ICP-Acid Dil. & $\mu \mathrm{g} / \mathrm{mL}$ & 96,70 & $<5.00 \mathrm{c}-01$ & $<5.000-01$ & $<5.00 \mathrm{e}-1$ & $\mathrm{n} / \mathrm{a}$ & $\mathbf{n} / \mathbf{a}$ & 89.60 & $5.000-01$ & $\mathbf{n} / \mathbf{a}$ \\
\hline S96T000855 & D & Vanadium-ICP-Acid Dil. & $\mu \mathrm{g} / \mathrm{mL}$ & 101.4 & $<5.000-02$ & $<5.00 \mathrm{e}-02$ & $<5.00 \mathrm{c}-2$ & $n / \mathbf{a}$ & $\mathbf{n} / \mathbf{a}$ & 98.50 & $5.00 c-02$ & $n / \mathbf{a}$ \\
\hline S96T000855 & D & Zinc-ICP-Acid Dil. & $\mu \mathrm{g} / \mathrm{mL}$ & 101.8 & $<1.00 \mathrm{e}-02$ & $<1.00 \mathrm{e}-02$ & $<1.00 \mathrm{e}-2$ & $n / a$ & $\mathrm{n} / \mathbf{a}$ & 100.8 & $1.00 e-02$ & $n / a$ \\
\hline S96T000855 & D & Zirconiurn-ICP-Acid Dil. & $\mu \mathrm{g} / \mathrm{mL}$ & 98.60 & $<1.00 \mathrm{e}-02$ & $<1.00 e-02$ & $<1.00 \mathrm{e}-2$ & $n / a$ & $\mathrm{n} / \mathrm{a}$ & 95.40 & $1.000-02$ & $n / a$ \\
\hline S96T000855 & & $\begin{array}{l}\text { Fluoride-IC-Dionex } \\
4000 \mathrm{i} / 4500\end{array}$ & $\mu \mathrm{g} / \mathrm{mL}$ & 101.0 & $<1.30 \mathrm{e}-02$ & $9.60 \mathrm{c}-02$ & $1.08 \mathrm{e}-01$ & $1.02 e-01$ & 11.8 & $\mathrm{n} / \mathbf{a}$ & $1.300-02$ & $n / a$ \\
\hline S96T000855 & & $\begin{array}{l}\text { Chloride-IC-Dionex } \\
4000 \mathrm{i} / 4500\end{array}$ & $\mu \mathrm{g} / \mathrm{mL}$ & 97.72 & $<1.70 e-02$ & 14.98 & 15.00 & 14.99 & 0.00 & $n / 2$ & $1.70 \mathrm{e}-02$ & $n / a$ \\
\hline S96T000855 & & Nitrite-IC-Dionex $4000 \mathrm{j} / 4500$ & $\mu \mathrm{g} / \mathrm{mL}$ & 103.0 & $<1.07 e-01$ & $6.32 \mathrm{e}-01$ & $6.22 \mathrm{e}-01$ & $6.27 \mathrm{e}-01$ & 1.59 & $n / \mathbf{a}$ & $1.07 e-01$ & $n / a$ \\
\hline S96T000855 & & Nitrate-IC-Dionex4000i/4500 & $\mu \mathrm{g} / \mathrm{mL}$ & 102.8 & $3.61 \mathrm{e}-01$ & 1.567 & 1.600 & 1.583 & 1.89 & $\mathbf{n} / \mathbf{a}$ & $1.400-01$ & $\mathrm{n} / \mathbf{a}$ \\
\hline S96T000855 & & $\begin{array}{l}\text { Phosphate-IC-Dionex } \\
4000 \mathrm{i} / 4500\end{array}$ & $\mu \mathrm{g} / \mathrm{mL}$ & 98.53 & $<1.19 \mathrm{e}-01$ & $4.59 \mathrm{e}-01$ & $4.18 \mathrm{c}-01$ & $4.39 e-01$ & 9.35 & $n / \mathbf{a}$ & $1.20 \mathrm{e}-01$ & $\mathrm{n} / \mathrm{a}$ \\
\hline S96T000855 & & $\begin{array}{l}\text { Sulfate by IC-Dionex } \\
4000 \mathrm{i} / 4500\end{array}$ & $\mu \mathrm{g} / \mathrm{mL}$ & 101.1 & $<1.360-01$ & 1.342 & 1.280 & 1.311 & 4.58 & $n / a$ & $1.360-01$ & $n / a$ \\
\hline S96T000855 & & Oxalate by IC-Dionex $4000 \mathrm{i}$ & $\mu \mathrm{g} / \mathrm{mL}$ & 104.2 & $<1.05 \mathrm{e}-01$ & $<1.05 \mathrm{e}-01$ & $<1.05 e-1$ & $n / \mathbf{a}$ & $n / 2$ & $n / \mathbf{a}$ & $1.05 e^{-01}$ & $\mathrm{n} / \mathrm{a}$ \\
\hline S96T000855 & & Cobalt-60 by GEA & $\mu \mathrm{Ci} / \mathrm{mL}$ & 100.4 & $<2.62 e-05$ & $<3.210-05$ & $<1.75 \mathrm{e}-5$ & $n / a$ & $\mathbf{n} / \mathbf{a}$ & $n / a$ & 3.210 .05 & $n / 2$ \\
\hline
\end{tabular}




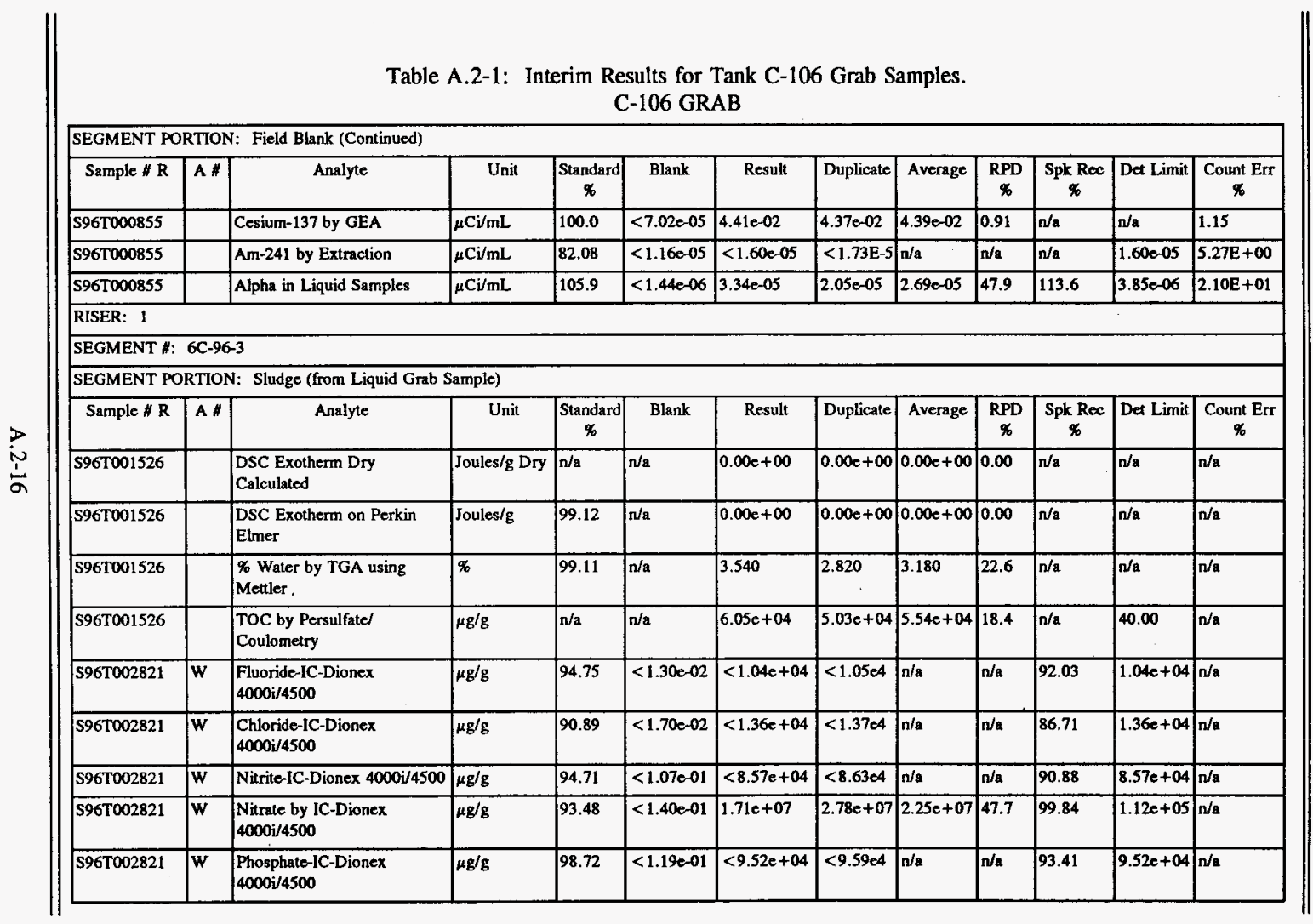




\begin{tabular}{|c|c|c|c|c|c|c|c|c|c|c|c|c|}
\hline \multicolumn{13}{|c|}{ SEGMENT PORTION: Sludge (from Liquid Grab Sample) (Continued) } \\
\hline Sample R & $A \#$ & Analyte & Unit & \begin{tabular}{|l|} 
Standard \\
$x$
\end{tabular} & Blank & Result & Duplicate $P$ & Average & $\begin{array}{l}\text { RPD } \\
\%\end{array}$ & $\begin{array}{l}\text { Spk Rec } \\
\% 6\end{array}$ & Dat Limit & $\begin{array}{l}\text { Count Err } \\
x^{2}\end{array}$ \\
\hline S96T002821 & $\bar{w}$ & $\begin{array}{l}\text { Sulfate by IC-Dionex } \\
4000 \mathrm{~V} / 4500\end{array}$ & $\mu \mathrm{g} / \mathrm{g}$ & 96.20 & $<1.36 \mathrm{e}-01$ & $<1.09 e+05$ & $<1.10 \mathrm{es}$ & $n / a$ & $n / a$ & 92.23 & $1.09 e+05$ & $\mathbf{n} / \mathbf{a}$ \\
\hline S96T002821 & $\mathbf{w}$ & 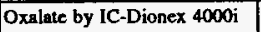 & $\mu g / g$ & 98.06 & $<1.050-01$ & $3.40 e+05$ & $3.68 c+05$ & $3.54 c+05$ & 7.91 & 92.82 & $8.41 e+04$ & $n / a$ \\
\hline S96T003178 & $\mathbf{W}$ & $\begin{array}{l}\text { Fluoride-IC-Dionex } \\
4000 \mathrm{i} / 4500\end{array}$ & $\mu \mathrm{g} / \mathrm{g}$ & 106.4 & $<1.30 \mathrm{e}-02$ & $2.14 e+02$ & 267.0 & 240.7 & 22.0 & 105.9 & 109.1 & $\pi / a$ \\
\hline S96T003178 & $\mathbf{w}$ & $\begin{array}{l}\text { Chloride-IC-Dionex } \\
4000 \mathrm{i} / 4500\end{array}$ & $\mu \mathrm{g} / \mathrm{g}$ & 98.23 & $<1.70 \mathrm{e}-02$ & $2.92 e+02$ & 310.0 & 300.9 & 5.98 & 92.91 & 142.6 & $\pi / a$ \\
\hline S96T003178 & w & Nitrite-IC-Dionex $4000 \mathrm{j} / 4500$ & $\mu \mathrm{g} / \mathrm{g}$ & 93.91 & $<1.07 \mathrm{e}-01$ & $1.32 e+04$ & $1.43 e+04$ & $1.37 \mathrm{e}+04$ & 8.00 & 87.64 & 897.5 & $\mathrm{n} / \mathrm{a}$ \\
\hline S96T003178 & $\mathbf{w}$ & $\begin{array}{l}\text { Nitrate by IC-Dionex } \\
4000 \mathrm{i} / 4500\end{array}$ & $\mu \mathrm{g} / \mathrm{g}$ & 104.1 & 5.770 & $2.96 c+03$ & $3.80 e+03$ & $3.38 \mathrm{e}+03$ & 24.9 & 93.97 & $1.17 e+03$ & $n / a$ \\
\hline S96T003178 & W & $\begin{array}{l}\text { Phosphate-IC-Dionex } \\
4000 \text { i/ } 4500\end{array}$ & $\mu g / g$ & 103.1 & $<1.19 \mathrm{e}-01$ & $1.66 e+03$ & $<1.4003$ & $n / \mathbf{a}$ & $\mathbf{n} / \mathbf{a}$ & 94.69 & 997.5 & $n / a$ \\
\hline S96T003178 & $\mathbf{w}$ & $\begin{array}{l}\text { Sulfate by IC-Dionex } \\
4000 \mathrm{i} / 4500\end{array}$ & $\mu g / g$ & 106.5 & $<1.36 \mathrm{e}-01$ & $5.34 e+03$ & $5.23 e+03$ & $5.29 e+03$ & 2.08 & 97.78 & $1.14 e+03$ & $n / \mathbf{n}$ \\
\hline $596 \mathrm{T003178}$ & $\mathbf{W}$ & Oxalate by IC-Dionex $4000 \mathrm{i}$ & $\mu \mathrm{g} / \mathrm{g}$ & 107.5 & $<1.05 \mathrm{e}-01$ & $3.08 \mathrm{e}+05$ & $3.19 e+05$ & $3.13 e+05$ & 3.51 & 34.25 & 881.1 & $n / a$ \\
\hline \multicolumn{13}{|l|}{ RISER: 1} \\
\hline \multicolumn{13}{|c|}{ SEGMENT \#: 6C-96-4 } \\
\hline \multicolumn{13}{|c|}{ SEGMENT PORTION: Centrifuged Solids (Grab Sample) } \\
\hline Sample $\mathrm{R}$ & A\# & Analyte & Unit & $\begin{array}{c}\text { Standard } \\
\%\end{array}$ & Blank & Result & Duplicate & Average & $\underset{x}{\text { RPD }}$ & \begin{tabular}{|c|} 
Spk Rec \\
$\%$
\end{tabular} & Det Limit & $\underset{\%}{\text { Count Err }}$ \\
\hline S96T001527 & & Bulk Density of Sample & $\mathrm{g} / \mathrm{mL}$ & $n / a$ & $n / a$ & 1.500 & $n / 2$ & $n / \mathbf{a}$ & $\mathbf{n} / \mathbf{a}$ & $n / a$ & $5.000-01$ & $\mathbf{n} / \mathbf{a}$ \\
\hline$\$ 96 T 001527$ & & DSC Exotherm using Metler & Joules/g & 111.4 & $n / a$ & $0.00 e+00$ & $1.00 c+03$ & 500.0 & 200 & $n / \mathbf{n}$ & $n / a$ & $\mathbf{n} / \mathbf{a}$ \\
\hline S96T0015271 & & DSC Exotherm using Mettler & Joules/g & 112.8 & $n / \mathbf{n}$ & 13.50 & 25.50 & 19.50 & 61.5 & $n / \mathbf{a}$ & $\mathbf{n} / \mathbf{a}$ & $\mathbf{n} / \mathbf{a}$ \\
\hline S96T001527 & & $\begin{array}{l}\text { DSC Exotherm Dry } \\
\text { Calculated }\end{array}$ & Joules/g Dry & $n / a$ & $n / a$ & $0.00 e+00$ & $1.04 c+03$ & 520.0 & 200 & $n / a$ & $n / \mathbf{a}$ & $\mathbf{n} / \mathbf{a}$ \\
\hline
\end{tabular}


Table A.2-1: Interim Results for Tank C-106 Grab Samples.

C-106 GRAB

SEGMENT PORTION: Centrifuged Solids (Grab Sample) (Continued)

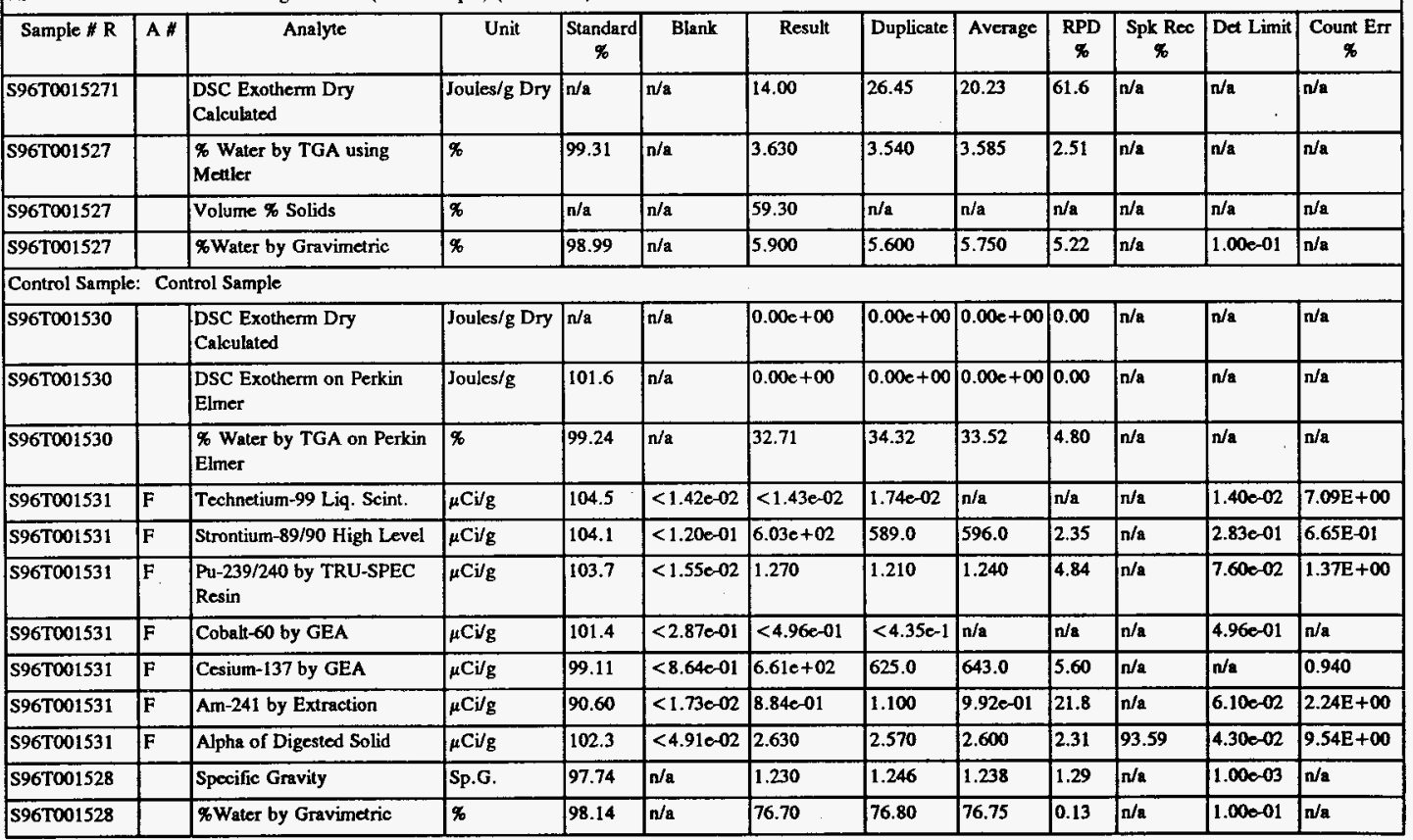




\begin{tabular}{|c|c|c|c|c|c|c|c|c|c|c|c|c|}
\hline \multicolumn{13}{|c|}{ Decanted Supernate (Liquid Grab Sludge); Decanted Supernate (Liquid Grab Sludge) } \\
\hline Sample \# R & A \# & Analyte & Unit & $\begin{array}{c}\text { Standard } \\
\%\end{array}$ & Blank & Result & Duplicate & Average & $\begin{array}{l}\text { RPD } \\
\%\end{array}$ & $\underset{\%}{\text { Spk Rec }}$ & Det Limit & $\begin{array}{c}\text { Count Err } \\
\%\end{array}$ \\
\hline S96T001537 & & $\begin{array}{l}\text { DSC Exotherm Dry } \\
\text { Calculated }\end{array}$ & Joules/g Dry & n/a & $n / \mathbf{a}$ & $0.00 e+00$ & $0.00 \mathrm{e}+\infty$ & $0.00 e+\infty$ & 0.00 & $\mathbf{n} / \mathbf{a}$ & $\mathrm{n} / \mathbf{a}$ & n/a \\
\hline S96T001537 & & $\begin{array}{l}\text { DSC Exotherm on Perkin } \\
\text { Elmer }\end{array}$ & Joules/g & 101.6 & $n / \mathfrak{a}$ & $0.00 e+\infty$ & $0.00 e+00$ & $0.00 e+00$ & 0.00 & $\mathbf{n} / \mathbf{a}$ & $n / \mathbf{a}$ & $n / \mathfrak{a}$ \\
\hline S96T001537 & & $\begin{array}{l}\text { \% Water by TGA on Perkin } \\
\text { Elmer }\end{array}$ & $\%$ & 99.24 & $n / \mathbf{a}$ & 22.14 & 26.07 & 24.11 & 16.3 & $\mathbf{n} / \mathbf{a}$ & n/a & $\mathbf{n} / \mathbf{a}$ \\
\hline S96T001538 & & TIC by Acid/Coulometry & $\mu \mathrm{g} / \mathrm{g}$ & 99.83 & $5.00 \mathrm{e}-0 \mathrm{t}$ & $2.54 e+04$ & $2.53 \mathrm{e}+04$ & $2.54 c+04$ & 0.39 & 102.1 & 5.000 & $n / \mathbf{a}$ \\
\hline S96T001538 & & $\begin{array}{l}\text { TOC by Persulfatel } \\
\text { Coulometry }\end{array}$ & $\mu \mathrm{g} / \mathrm{g}$ & 92.36 & 1.600 & $1.48 c+04$ & $1.64 c+04$ & $1.56 e+04$ & 10.3 & 84.80 & 40.00 & $n / a$ \\
\hline S96T001539 & & \% Water by Gravimetric & $\%$ & 99.32 & $\mathrm{n} / \mathbf{a}$ & 27.10 & 23.10 & 25.10 & 15.9 & $n / \mathbf{a}$ & $1.000-02$ & $n / a$ \\
\hline S96T001540 & & $\mathrm{pH}$ on SST Samples & $\mathrm{pH}$ & $n / a$ & $n / a$ & 10.21 & 10.18 & 10.20 & 0.29 & $n / \mathbf{a}$ & $1.000-02$ & $n / \mathbf{a}$ \\
\hline S96T001541 & $F$ & Technetium-99 Liq. Scint. & $\mu \mathrm{Ci} / \mathrm{g}$ & 104.5 & $<1.42 \mathrm{e}-02$ & $<1.54 \mathrm{e}-02$ & $1.75 \mathrm{e}-02$ & $\mathbf{n} / \mathbf{a}$ & $\mathbf{n} / \mathbf{a}$ & n/a & $1.50 \mathrm{e}-02$ & $7.12 E+00$ \\
\hline S96T001541 & $\mathrm{F}$ & Strontium-89/90 High Level & $\mu \mathrm{Ci} / \mathrm{g}$ & 104.1 & $<1.20 \mathrm{e}-01$ & $6.65 \mathrm{e}+02$ & 721.0 & 693.0 & 8.08 & $n / \mathbf{a}$ & $2.860-01$ & $6.36 \mathrm{E}-01$ \\
\hline S96T001541 & $F$ & $\begin{array}{l}\text { Pu-239/240 by TRU-SPEC } \\
\text { Resin }\end{array}$ & $\mu \mathrm{Ci} / \mathrm{g}$ & 103.7 & $<1.55 \mathrm{e}-02$ & 1.420 & 1.480 & 1.450 & 4.14 & $\pi / \mathbf{a}$ & $8.100-02$ & $1.42 E+00$ \\
\hline S96T001541 & $F$ & Cobalt-60 by GEA & $\mu \mathrm{Ci} / \mathrm{g}$ & 101.4 & $<2.87 e-01$ & $<5.48 \mathrm{e}-01$ & $<5.72 \mathrm{e}-1$ & n/a & $n / \mathbf{a}$ & $n / a$ & $5.48 e-01$ & $\mathbf{n} / \mathbf{a}$ \\
\hline S96T001541 & $F$ & Cesium- 137 by GEA & $\mu \mathrm{Ci} / \mathrm{g}$ & 99.11 & $<8.64=-01$ & $6.16 e+02$ & 671.0 & 643.6 & 8.55 & $n / a$ & $n / a$ & 1.02 \\
\hline S96T001541 & $F$ & Am- 241 by Extraction & $\mu \mathrm{Ci} / \mathrm{g}$ & 90.60 & $<1.73 \mathrm{e}-02$ & 1.150 & 1.560 & 1.355 & 30.3 & $n / a$ & $7.40 \mathrm{e}-02$ & $1.69 \mathrm{E}+00$ \\
\hline$\$ 967001541$ & $F$ & Alpha of Digested Solid & $\mu \mathrm{Ci} / \mathrm{g}$ & 102.3 & $<4.91002$ & 3.120 & 3.310 & 3.215 & 5.91 & 94.43 & $4.800-02$ & $9.29 \mathrm{E}+00$ \\
\hline$\$ 96 \mathrm{~T} 001542$ & $A$ & Silver-ICP-Acid Digest & $\mu \mathrm{g} / \mathrm{g}$ & 89.40 & $<1.00 \mathrm{e}-02$ & $2.50 c+03$ & $1.51 e+03$ & $2.00 c+03$ & 49.4 & $n / a$ & 6.140 & $n / a$ \\
\hline $596 \mathrm{~T} 001542$ & $\mathbf{A}$ & Aluminum-ICP-Acid Digest & $\mu g / g$ & 91.00 & $1.17 e-01$ & $6.20 e+04$ & $5.44 \mathrm{e}+04$ & $5.82 e+04$ & 13.1 & $n / a$ & 30.70 & $n / a$ \\
\hline S96T001542 & A & Arsenic-ICP-Acid Digest & $\mu \mathrm{g} / \mathrm{g}$ & 94.00 & $<1.000-01$ & $<61.40$ & $<5.91 \mathrm{el}$ & $n / a$ & $n / a$ & 84.70 & 61.40 & $\mathbf{n} / \mathbf{a}$ \\
\hline S96T001542 & A & Boron-ICP-Acid Digest & $\mu g / g$ & 97.40 & $5.88 \mathrm{e}-01$ & 59.20 & 72.10 & 65.65 & 19.6 & 87.82 & 30.70 & $\mathbf{n} / \mathbf{a}$ \\
\hline S96T001542 & A & Barium-ICP-Acid Digest & $\mu \mathrm{g} / \mathrm{g}$ & 94.00 & $<5.00 \mathrm{e}-02$ & $3.79 e+02$ & 330.0 & 354.5 & 13.8 & 85.52 & 30.70 & $\mathbf{n} / \mathbf{a}$ \\
\hline
\end{tabular}




\begin{tabular}{|c|c|c|c|c|c|c|c|c|c|c|c|c|}
\hline \multicolumn{13}{|c|}{ Decanted Supernate (Liquid Grab Sludge): Decanted Supernate (Liquid Grab Sludge) (Continued) } \\
\hline Sample \# R & $A \#$ & Analyte & Unit & $\begin{array}{c}\text { Standard } \\
\%\end{array}$ & Blank & Result & Duplicate & Average & $\underset{\%}{\text { RPD }}$ & $\begin{array}{c}\text { Spk Rec } \\
\%\end{array}$ & Det Limit & $\begin{array}{c}\text { Count Err } \\
\%\end{array}$ \\
\hline S96T001542 & A & Beryllium-ICP-Acid Digest & $\mu \mathrm{g} / \mathrm{g}$ & 103.6 & $<5.000-03$ & $<3.070$ & $<2.9500$ & $n / \mathbf{a}$ & $\mathbf{n} / \mathbf{a}$ & 91.70 & 3.070 & $n / \mathbf{a}$ \\
\hline S96T001542 & A & Bismuth-ICP-AcidDigest & $\mu \mathrm{g} / \mathrm{g}$ & 89.60 & $<1.00 \mathrm{e}-01$ & $<61.40$ & $<5.91 \mathrm{e} 1$ & $n / \mathbf{a}$ & $\mathbf{n} / \mathbf{a}$ & 86.10 & 61.40 & $\mathbf{n} / \mathbf{a}$ \\
\hline \$96T001542 & A & Calcium-ICP-AcidDigest & $\mu \mathrm{g} / \mathrm{g}$ & 91.20 & $<1.00 e-01$ & $1.17 c+03$ & $1.18 c+03$ & $1.18 \mathrm{e}+03$ & 0.85 & 80.76 & 61.40 & $\mathbf{n} / \mathbf{a}$ \\
\hline S96T001542 & $\mathrm{A}$ & Cadmium-ICP-Acid Digest & $\mu g / g$ & 89.20 & $<5.00 \mathrm{e}-03$ & 37.90 & 33.00 & 35.45 & 13.8 & 86.06 & 3.070 & $\mathbf{n} / \mathbf{a}$ \\
\hline S96T001542 & $A$ & Cerium-ICP-Acid Digest & $\mu \mathrm{g} / \mathrm{g}$ & 96.60 & $<1.00 \mathrm{e}-01$ & $2.42 e+02$ & 233.0 & 237.5 & 3.79 & 91.20 & 61.40 & $n / \mathbf{a}$ \\
\hline S96T001542 & A & Cobalt-ICP-Acid Digest & $\mu \mathrm{g} / \mathrm{g}$ & 91.80 & $<2.000-02$ & 12.30 & $<1.18 \mathrm{el}$ & $n / a$ & n/a & 88.10 & 12.30 & n/a \\
\hline S96T001542 & A & Chromium-ICP-Acid Digest & $\mu \mathrm{g} / \mathrm{g}$ & 90.80 & $<1.00=-02$ & $7.30 e+02$ & 660.0 & 695.0 & 10.1 & 84.36 & 6.140 & $\mathbf{n} / \mathbf{a}$ \\
\hline S96T001542 & A & Copper-ICP-Acid Digest & $\mu g / g$ & 91.60 & $1.10 \mathrm{e}-02$ & 93.70 & 80.40 & 87.05 & 15.3 & 84.82 & 6.140 & $\mathbf{n} / \mathbf{a}$ \\
\hline S96T001542 & A & Iron-ICP-Acid Digest & $\mu \mathrm{g} / \mathrm{B}$ & 91.60 & $<5.000-02$ & $8.31 \mathrm{e}+04$ & $7.15 e+04$ & $7.73 e+04$ & 15.0 & $n / a$ & 30.70 & $n / \mathbf{a}$ \\
\hline S96T001542 & A & Potassium-ICP-Acid Digest & $\mu \mathrm{g} / \mathrm{g}$ & 94.00 & $<5.00 \mathrm{e}-01$ & $9.05 e+02$ & 644.0 & 774.5 & 33.7 & 77.82 & 307.0 & $n / a$ \\
\hline S96T001542 & A & Lanthanum-ICP-Acid Digest & $\mu \mathrm{g} / \mathrm{g}$ & 93.80 & $<5.00 \mathrm{e}-02$ & 80.30 & 72.00 & 76.15 & 10.9 & 88.08 & 30.70 & $\mathrm{n} / \mathrm{a}$ \\
\hline S96T001542 & A & Lithium-ICP-Acid Digest & $\mu \mathrm{g} / \mathrm{g}$ & 94.20 & $<1.00 \mathrm{e}-02$ & $<6.140$ & $<5.9100$ & $n / a$ & $n / a$ & 86.90 & 6.140 & $n / a$ \\
\hline S96T001542 & A & Magnesium-ICP-Acid Digest & $\mu \mathrm{g} / \mathrm{g}$ & 86.00 & $<1.00=-01$ & $3.21 \mathrm{e}+02$ & 283.0 & 302.0 & 12.6 & 79.10 & 61.40 & $\mathrm{n} / \mathrm{a}$ \\
\hline S96T001542 & A & Mangancse-ICP-Acid Digest & $\mu \mathrm{g} / \mathrm{g}$ & 90.20 & $<1.00 \mathrm{e}-02$ & $2.28 \mathrm{e}+03$ & $2.00 e+03$ & $2.14 e+03$ & 13.1 & 78.58 & 6.140 & $n / a$ \\
\hline S96T001542 & A & $\begin{array}{l}\text { Molybdenum-ICP-Acid } \\
\text { Digest }\end{array}$ & $\mu \mathrm{g} / \mathrm{g}$ & 90.80 & $<5.00 \mathrm{e}-02$ & $<<30.70$ & $<2.95 \mathrm{e} 1$ & $n / a$ & $n / 2$ & 86.80 & 30.70 & $n / a$ \\
\hline $596 \mathrm{~T} 001542$ & A & Sodium-ICP-Acid Digest & $\mu \mathrm{g} / \mathrm{g}$ & 103.2 & $8.79 \mathrm{e}-01$ & $1.40 e+05$ & $1.29 e+05$ & $1.34 e+05$ & 8.18 & $n / \mathbf{a}$ & 61.40 & $n / a$ \\
\hline$\$ 96 T 001542$ & A & Neodymium-ICP-Acid Digest & $\mu \mathrm{g} / \mathrm{g}$ & 93.40 & $<1.00 \mathrm{e}-01$ & $1.92 e+02$ & 176.0 & 184.0 & 8.70 & 87.22 & 61.40 & $n / \mathbf{a}$ \\
\hline S96T001542 & A & Nickel-ICP-Acid Digest & $\mu \mathrm{g} / \mathrm{g}$ & 92.00 & $<2.00 \mathrm{e}-02$ & $7.70 e+02$ & 694.0 & 732.0 & 10.4 & 86.38 & 12.30 & $n / a$ \\
\hline S96T001542 & $\mathbf{A}$ & Phosphorus-ICP-Acid Digest & $\mu \mathrm{g} / \mathrm{g}$ & 94.00 & $<2.000-01$ & $2.75 e+03$ & $2.50 c+03$ & $2.62 e+03$ & 9.52 & 57.92 & 123.0 & $n / \mathbf{a}$ \\
\hline S96T001542 & A & Lead-ICP-Acid Digest & $\mu \mathrm{g} / \mathrm{g}$ & 86.20 & $<1.00 \mathrm{e}-01$ & $2.90 e+03$ & $2.54 e+03$ & $2.72 e+03$ & 13.2 & 74.32 & 61.40 & $\pi / a$ \\
\hline S96T001542 & A & Sulfur-ICP-Acid Digest & $\mu \mathrm{g} / \mathrm{g}$ & 89.20 & $<1.00<-01$ & $1.40 e+03$ & $1.14 e+03$ & $1.27 e+03$ & 20.5 & 74.82 & 61.40 & $\mathrm{n} / \mathrm{s}$ \\
\hline
\end{tabular}




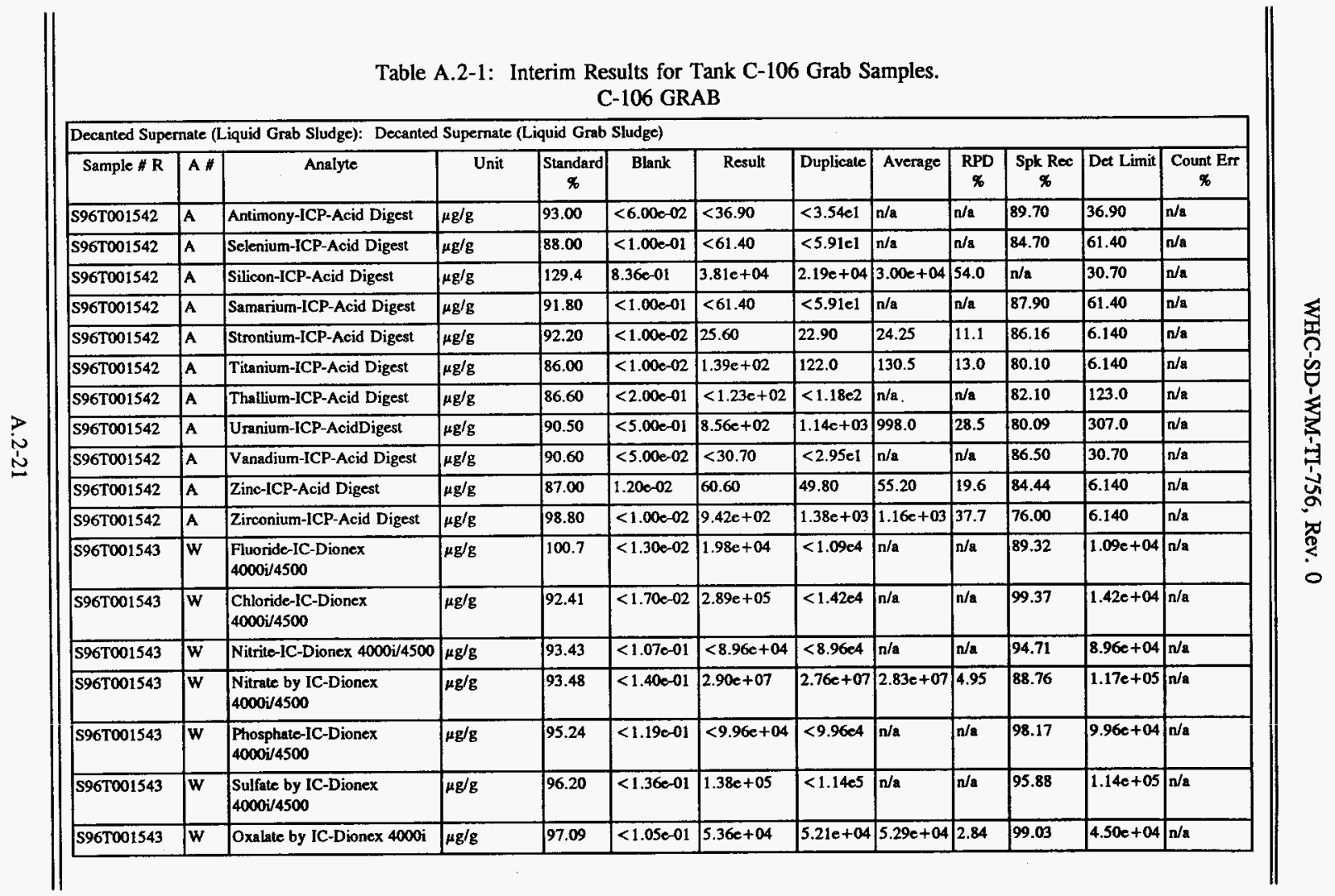


Table A.2-1: Interim Results for Tank C-106 Grab Samples.

C-106 GRAB

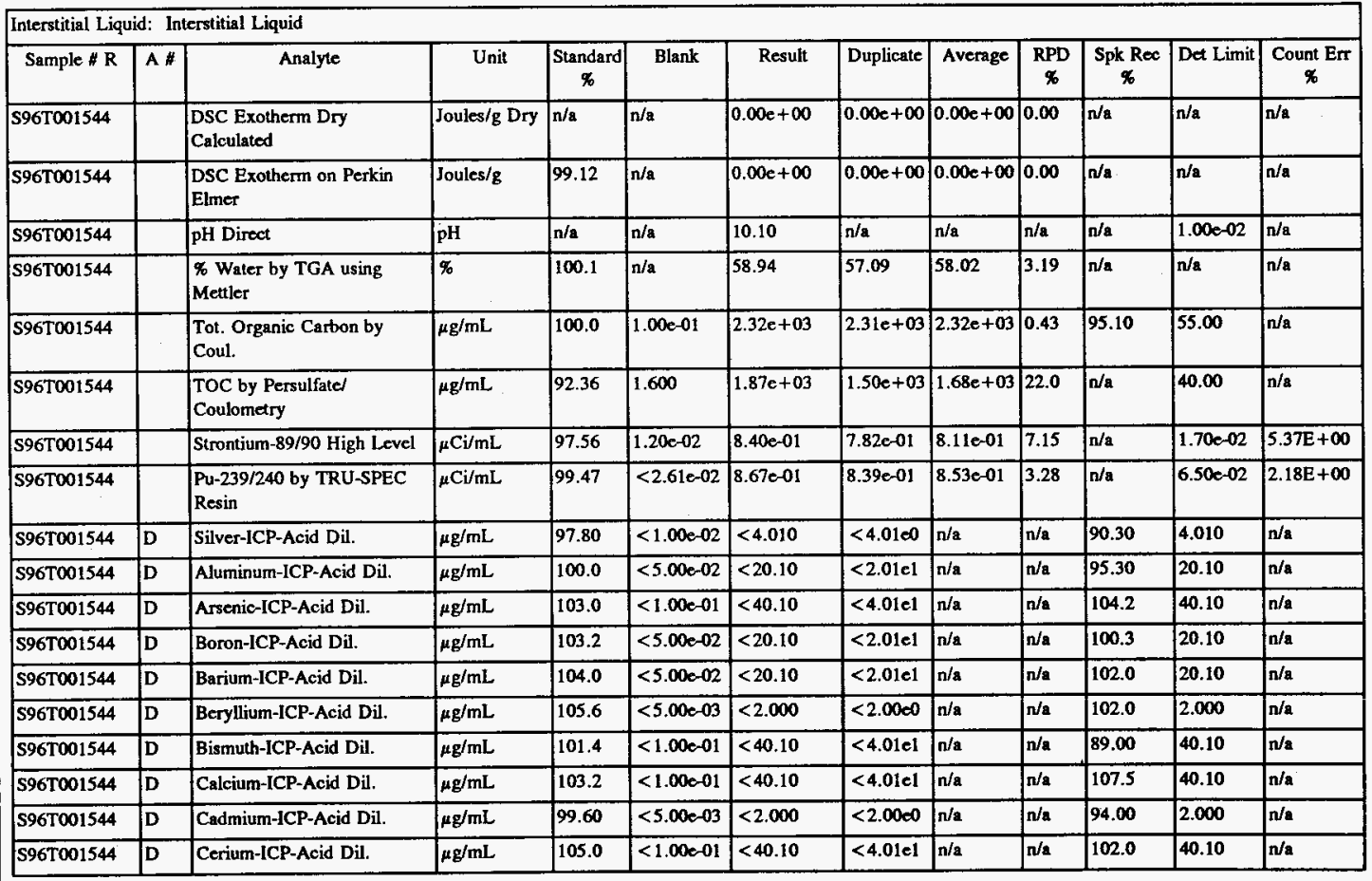




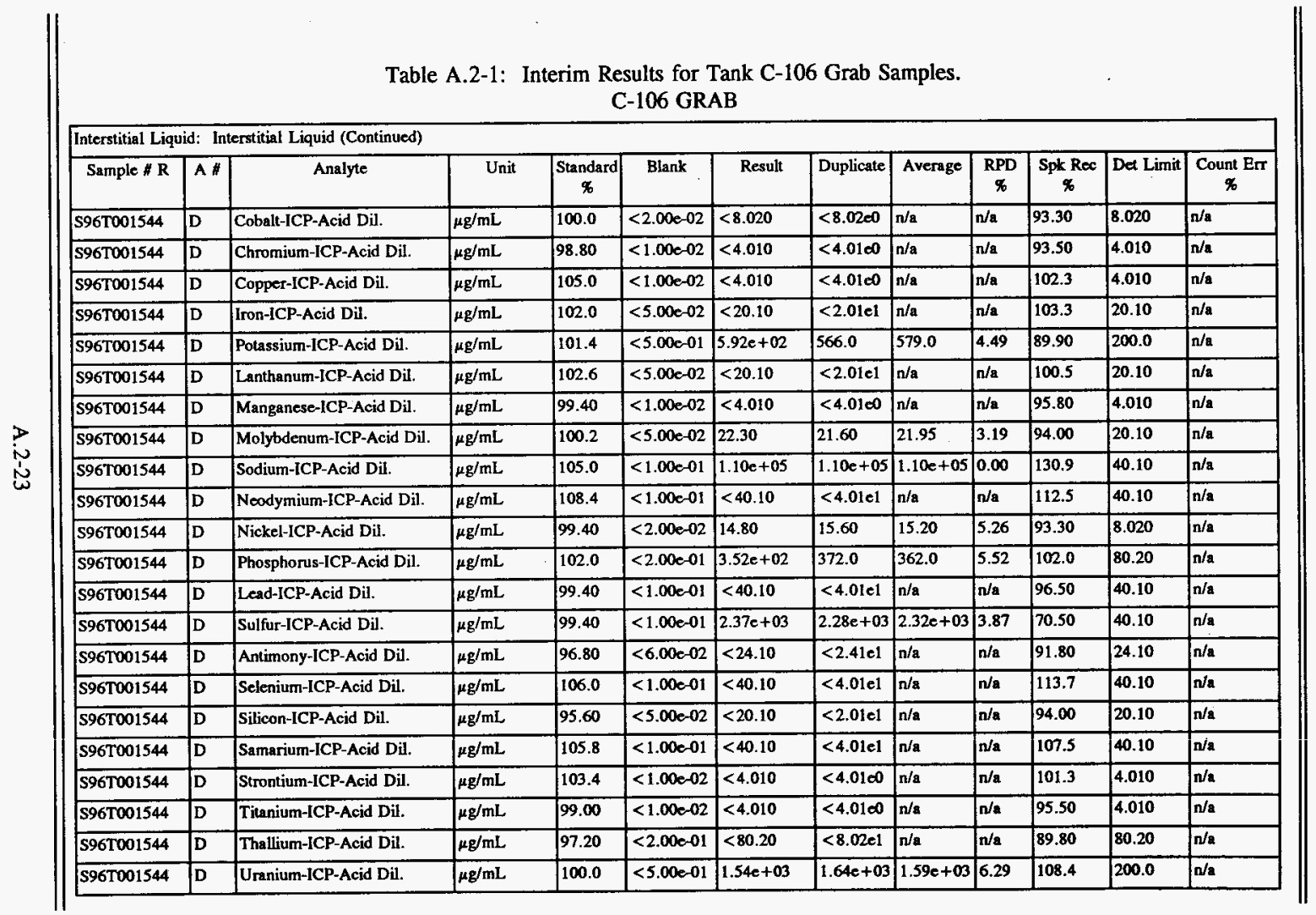


Table A.2-1: Interim Results for Tank C-106 Grab Samples.

C-106 GRAB

Interstitial Liquid: Interstitial Liquid (Continued)

\begin{tabular}{|c|c|c|c|c|c|c|c|c|c|c|c|c|}
\hline Sample \# $\mathbf{R}$ & $A \#$ & Analyte & Unit & \begin{tabular}{|c|} 
Standard \\
$\%$
\end{tabular} & Blank & Result & Duplicate & Average & $\begin{array}{c}\text { RPD } \\
\%\end{array}$ & $\begin{array}{c}\text { Spk Rec } \\
\%\end{array}$ & Det Limit & $\begin{array}{c}\text { Count Err } \\
\%\end{array}$ \\
\hline S96T001544 & D & Vanadium-ICP-Acid Dil. & $\mu \mathrm{g} / \mathrm{mL}$ & 102.0 & $<5.00 \mathrm{e}-02$ & $<20.10$ & $<2.01 \mathrm{el}$ & $n / \mathbf{a}$ & $\mathrm{n} / \mathbf{a}$ & 97.50 & 20.10 & $n / a$ \\
\hline S96T001544 & D & Zinc-ICP-Acid Dil. & $\mu \mathrm{g} / \mathrm{mL}$ & 100.0 & $<1.00 \mathrm{e}-02$ & 5.250 & 5.980 & 5.615 & 13.0 & 92.70 & 4.010 & $n / \mathbf{a}$ \\
\hline S96T001544 & D & Zirconium-ICP-Acid Dil. & $\mu \mathrm{g} / \mathrm{mL}$ & 101.4 & $<1.00 c-02$ & $3.72 c+02$ & 378.0 & 375.0 & 1.60 & 101.1 & 4.010 & $\mathrm{n} / \mathrm{a}$ \\
\hline S96T001544 & & $\begin{array}{l}\text { Fluoride-IC-Dionex } \\
4000 \mathrm{i} / 4500\end{array}$ & $\mu \mathrm{g} / \mathrm{mL}$ & 98.81 & $<1.30<-02$ & $1.97 e+02$ & 199.0 & 198.2 & 1.01 & $\mathbf{n} / \mathbf{a}$ & 14.44 & $n / a$ \\
\hline $596 \mathrm{~T} 001544$ & & $\begin{array}{l}\text { Chloride-IC-Dionex } \\
4000 \mathrm{i} / 4500\end{array}$ & $\mu \mathrm{g} / \mathrm{mL}$ & 93.17 & $<1.70 \mathrm{e}-02$ & $5.84 e+02$ & 588.0 & 586.1 & 0.68 & $n / a$ & 18.89 & $n / a$ \\
\hline S96T001544 & & Nitrite-IC-Dionex $4000 \mathrm{j} / 4500$ & $\mu \mathrm{g} / \mathrm{mL}$ & 98.61 & $<1.07 \mathrm{e}-01$ & $2.59 c+04$ & $2.62 e+04$ & $2.60 e+04$ & 1.15 & $n / a$ & 118.9 & $\mathrm{n} / \mathrm{a}$ \\
\hline S96T001544 & & Nitrate-IC-Dionex $4000 \mathrm{~V} / 4500$ & $\mu \mathrm{g} / \mathrm{mL}$ & 99.67 & $2.38 \mathrm{e}-01$ & $9.43 c+02$ & 954.0 & 948.5 & 1.16 & $\mathbf{n} / \mathbf{a}$ & 155.5 & $n / a$ \\
\hline S96T001544 & & $\begin{array}{l}\text { Phosphate-IC-Dionex } \\
4000 \mathrm{i} / 4500\end{array}$ & $\mu \mathrm{g} / \mathrm{mL}$ & 100.7 & $<1.19 \mathrm{e}-01$ & $5.85 e+02$ & 547.0 & 565.9 & 6.71 & $\mathbf{n} / \mathbf{a}$ & 132.1 & $n / a$ \\
\hline S96T001544 & & $\begin{array}{l}\text { Sulfate by IC-Dionex } \\
4000 \mathrm{~d} / 4500\end{array}$ & $\mu \mathrm{g} / \mathrm{mL}$ & 99.53 & $<1.36 \mathrm{e}-01$ & $6.83 e+03$ & $6.86 e+03$ & $6.85 e+03$ & 0.44 & $n / a$ & 151.0 & $n / a$ \\
\hline S96T001544 & & Oxalate by IC-Dionex $4000 \mathrm{i}$ & $\mu \mathrm{g} / \mathrm{mL}$ & 100.2 & $<1.050-01$ & $2.19 e+03$ & $2.23 e+03$ & $2.21 c+03$ & 1.81 & $\mathrm{n} / \mathrm{a}$ & 116.7 & $n / a$ \\
\hline S96T001544 & & Cobalt- 60 by GEA & $\mu \mathrm{Ci} / \mathrm{mL}$ & 98.94 & $<2.16 e-02$ & $<3.38 \mathrm{e}-02$ & $<2.27 e-2$ & $n / a$ & $n / a$ & $\mathrm{n} / \mathbf{a}$ & $3.40 c-02$ & $n / \mathbf{a}$ \\
\hline \$96T001544 & & Cesium- 137 by GEA & $\mu \mathrm{Ci} / \mathrm{mL}$ & 100.4 & $<6.06 \mathrm{e}-02$ & $1.59 \mathrm{e}+02$ & 157.0 & 158.0 & 1.27 & $\mathrm{n} / \mathbf{a}$ & $\mathrm{n} / \mathbf{a}$ & 0.550 \\
\hline \multicolumn{13}{|c|}{ Potential Organic Layer: Potential Organic Layer } \\
\hline S96T001545 & & $\begin{array}{l}\text { Pu-239/240 by TRU-SPEC } \\
\text { Resin }\end{array}$ & $\mu \mathrm{Ci} / \mathrm{mL}$ & 96.33 & $<3.03 \mathrm{e}-05$ & $4.26 \mathrm{e}-03$ & $4.21 \mathrm{e}-03$ & $4.24 \mathrm{e} .03$ & 1.18 & $\mathrm{n} / \mathbf{a}$ & $3.06 \mathrm{e}-04$ & $2.23 \mathrm{E}+00$ \\
\hline \multicolumn{13}{|c|}{ Sludge (from Liquid Grab Sample): Sludge (from Liquid Grab Sample) } \\
\hline S96T003179 & $\mathbf{w}$ & $\begin{array}{l}\text { Fluoride-IC-Dionex } \\
4000 \mathrm{j} / 4500\end{array}$ & $\mu \mathrm{g} / \mathrm{g}$ & 106.4 & $<1.30 \mathrm{e}-02$ & $4.95 e+02$ & 142.0 & 318.3 & 111 & $\mathrm{n} / \mathbf{a}$ & 56.77 & $n / a$ \\
\hline S96T003179 & $\mathbf{w}$ & $\begin{array}{l}\text { Chloride-IC-Dionex } \\
4000 \mathrm{i} / 4500\end{array}$ & $\mu \mathrm{g} / \mathrm{g}$ & 98.23 & $<1.70 \mathrm{e}-02$ & $6.36 e+02$ & 261.0 & 448.7 & 83.6 & $\mathrm{n} / \mathrm{a}$ & 74.24 & $\pi / a$ \\
\hline
\end{tabular}


Table A.2-1: Interim Results for Tank C-106 Grab Samples.

C-106 GRAB

Sludge (from Liquid Grab Sample): Sludge (from Liquid Grab Sample) (Continued)

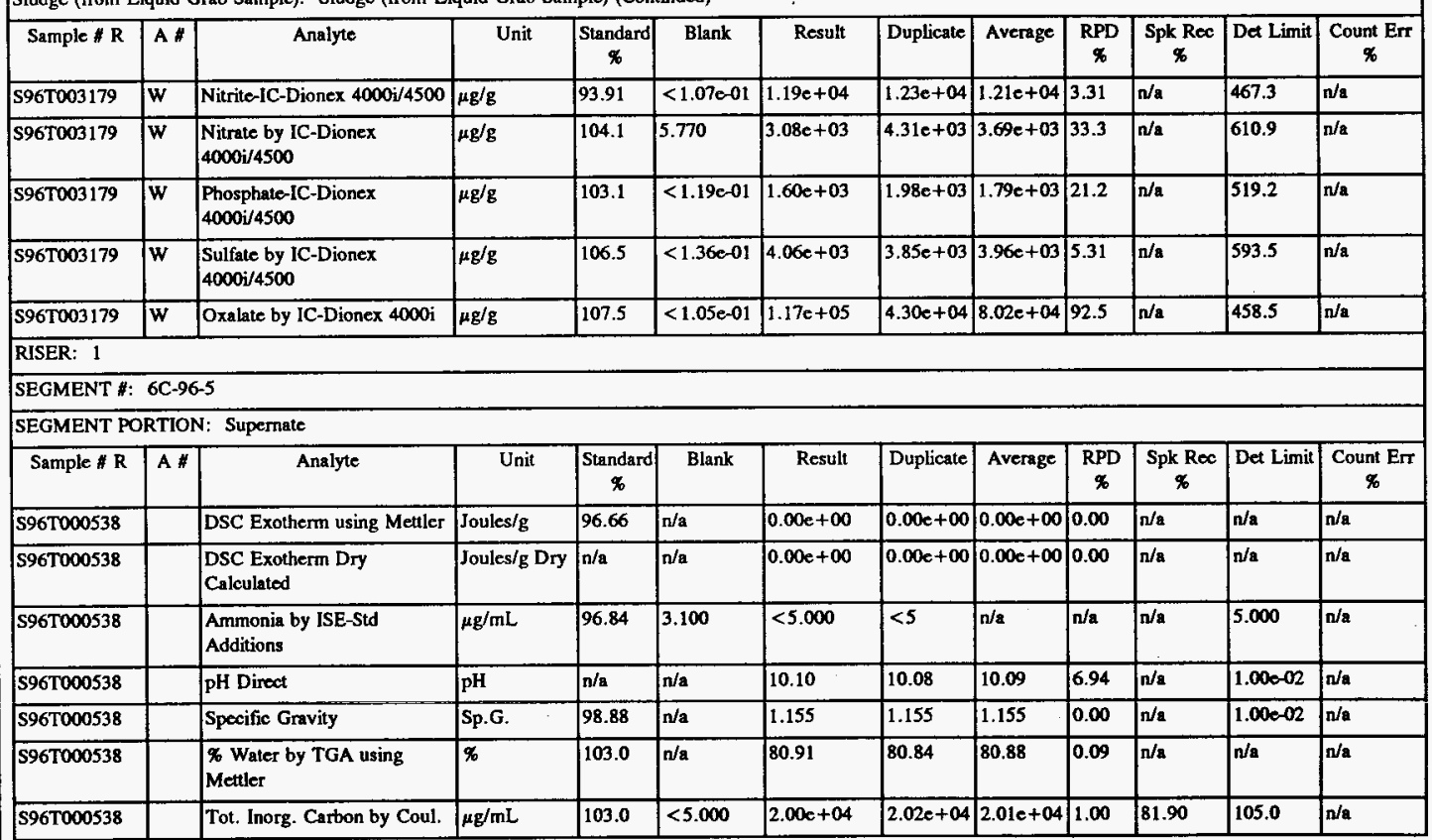




\begin{tabular}{|c|c|c|c|c|c|c|c|c|c|c|c|c|}
\hline \multicolumn{13}{|c|}{ SEGMENT PORTION: Supernate (Continued) } \\
\hline Sample \# R & A\# & Analyte & Unit & \begin{tabular}{|c|} 
Standard \\
$\%$
\end{tabular} & Blank & Result & Duplicate & Average & $\underset{\%}{\text { RPD }}$ & $\begin{array}{c}\text { Spk Rec } \\
\%\end{array}$ & Det Limit & $\begin{array}{c}\text { Count Err } \\
\star\end{array}$ \\
\hline S96T000538 & & $\begin{array}{l}\text { Tot. Organic Carton by } \\
\text { Coul. }\end{array}$ & $\mu \mathrm{g} / \mathrm{mL}$ & 97.03 & $<5.000$ & $3.36 e+03$ & $3.24 e+03$ & $3.30 e+03$ & 3.64 & 95.40 & 55.00 & $\mathbf{n} / \mathbf{a}$ \\
\hline S96TC00538 & & $\begin{array}{l}\text { TOC by Persulfatel } \\
\text { Coulometry }\end{array}$ & $\mu \mathrm{g} / \mathrm{mL}$ & 96.70 & 9.900 & $2.30 \mathrm{e}+03$ & $2.18 e+03$ & $2.24 e+03$ & 5.36 & $\mathrm{n} / \mathbf{a}$ & 40.00 & $n / \mathbf{a}$ \\
\hline S96T000538 & & \% Water by Gravimetric & $\%$ & 102.0 & $n / a$ & 81.40 & 81.40 & 81.40 & 0.00 & $\mathrm{n} / \mathrm{a}$ & $1.00 e-02$ & $\mathrm{n} / \mathrm{a}$ \\
\hline S96T000538 & D & Silver-ICP-Acid Dil. & $\mu \mathrm{g} / \mathrm{mL}$ & 100.8 & $<1.00 \mathrm{e}-02$ & 11.20 & 9.690 & 10.45 & 14.5 & 80.10 & 4.010 & $\mathrm{n} / \mathrm{a}$ \\
\hline S96T000538 & D & Aluminum-ICP-Acid Dil. & $\mu \mathrm{g} / \mathrm{mL}$ & 98.40 & $<5.00 \mathrm{e}-02$ & $<20.00$ & $<2.00 \mathrm{e} 1$ & $n / a$ & $n / a$ & 97.40 & 20.10 & $n / a$ \\
\hline S96T000538 & D & Arsenic-ICP-Acid Dil. & $\mu \mathrm{g} / \mathrm{mL}$ & 103.8 & $<1.00 \mathrm{e}-01$ & $<40.10$ & $<4.01 \mathrm{el}$ & $n / a$ & $n / a$ & 100.8 & 40.10 & $n / a$ \\
\hline \$96T000538 & D & Boron-ICP-Acid Dil. & $\mu \mathrm{g} / \mathrm{mL}$ & 100.4 & $<5.000-02$ & $<20.00$ & $<2.00 \mathrm{cl}$ & $n / a$ & $n / a$ & 101.6 & 20.10 & $n / a$ \\
\hline S96T000538 & D & Barium-ICP-Acid Dil. & $\mu \mathrm{g} / \mathrm{mL}$ & 102.6 & $<5.00 \mathrm{e}-02$ & $<20.00$ & $<2.00 \mathrm{el}$ & $n / a$ & $n / a$ & 98.60 & 20.10 & $\mathrm{n} / \mathrm{a}$ \\
\hline S96T000538 & D & Beryllium-ICP-Acid Dil. & $\mu \mathrm{g} / \mathrm{mL}$ & 104.0 & $<5.00 \mathrm{e}-03$ & $<2.000$ & $<2.00 \mathrm{en}$ & $n / a$ & $n / a$ & 101.6 & 2.000 & $n / a$ \\
\hline S96T000538 & $\mathrm{D}$ & Bismuth-ICP-Acid Dil. & $\mu \mathrm{g} / \mathrm{mL}$ & 101.8 & $<1.00 \mathrm{e}-01$ & $<40.10$ & $<4.01 \mathrm{cl}$ & $n / \mathbf{a}$ & $\mathrm{n} / \mathrm{a}$ & 100.8 & 40.10 & $\mathrm{n} / \mathrm{a}$ \\
\hline S96T000538 & D & Calcium-ICP-Acid Dil. & $\mu \mathrm{g} / \mathrm{mL}$ & 104.2 & $<1.00 \mathrm{e}-01$ & $<40.10$ & $<4.01 \mathrm{e} 1$ & $\pi / \mathbf{a}$ & $n / a$ & 105.3 & 40.10 & $n / 8$ \\
\hline S96T000538 & D & Cadmium-ICP-Acid Dil. & $\mu \mathrm{g} / \mathrm{mL}$ & 102.8 & $<5.00 k-03$ & $<2.000$ & $<2.00 \mathrm{c0}$ & $\mathrm{n} / \mathrm{a}$ & $n / a$ & 101.8 & 2.000 & $n / a$ \\
\hline S96T000538 & $\mathrm{D}$ & Cerium-ICP-Acid Dil. & $\mu \mathrm{g} / \mathrm{mL}$ & 105.6 & $<1.00 \mathrm{e}-01$ & $<40.10$ & $<4.01 \mathrm{el}$ & $\mathrm{n} / \mathbf{a}$ & $\mathrm{n} / \mathrm{a}$ & 105.1 & 40.10 & $n / a$ \\
\hline S96T000538 & D & Cobalt-ICP-Acid Dil. & $\mu \mathrm{g} / \mathrm{mL}$ & 103.4 & $<2.000-02$ & $<8.020$ & $<8.0200$ & $n / a$ & $n / a$ & 101.8 & 8.020 & $n / a$ \\
\hline $596 \mathrm{T000538}$ & D & Chromium-ICP-Acid Dil. & $\mu \mathrm{g} / \mathrm{mL}$ & 104.0 & $<1.00 \mathrm{e}-02$ & $<4.010$ & $<4.0100$ & $\mathbf{n} / \mathbf{a}$ & $n / a$ & \begin{tabular}{|l|}
102.8 \\
\end{tabular} & 4.010 & $n / a$ \\
\hline S96T000538 & $\mathrm{D}$ & Copper-ICP-Acid Dil. & $\mu \mathrm{g} / \mathrm{mL}$ & 104.2 & $<1.00 \mathrm{e}-02$ & $<4.010$ & $<4.01 \mathrm{e} 0$ & $n / \mathbf{a}$ & $n / a$ & 99.60 & 4.010 & $n / a$ \\
\hline S96T000538 & D & Iron-ICP-Acid Dil. & $\mu \mathrm{g} / \mathrm{mL}$ & 103.2 & $<5.000-02$ & $<20.00$ & $<2.00 \mathrm{el}$ & $n / a$ & $n / a$ & 102.3 & 20.10 & $n / a$ \\
\hline S96T000538 & $D$ & Potassium-ICP-Acid Dil. & $\mu \mathrm{g} / \mathrm{mL}$ & 103.4 & $<5.00 \mathrm{e}-01$ & $8.01 e+02$ & 658.0 & 729.5 & 19.6 & 67.30 & 200.0 & $n / a$ \\
\hline S96T000538 & D & Lanthanum-ICP-Acid Dil. & $\mu \mathrm{g} / \mathrm{mL}$ & 103.6 & $<5.00 \mathrm{e}-02$ & $<20.00$ & $<2.00 \mathrm{e} 1$ & $n / \mathbf{a}$ & $n / a$ & 101.1 & 20.10 & $n / \mathbf{a}$ \\
\hline S96T000538 & $\bar{D}$ & Lithium-ICP-Acid Dil. & $\mu \mathrm{g} / \mathrm{mL}$ & 99.60 & $<1.000-02$ & $<4.010$ & $<4.0100$ & $n / \mathbf{a}$ & $n / \mathbf{a}$ & 97.90 & 4.010 & $n / \mathbf{a}$ \\
\hline
\end{tabular}




\begin{tabular}{|c|c|c|c|c|c|c|c|c|c|c|c|c|}
\hline \multicolumn{13}{|c|}{ SEGMENT PORTION: Supernale (Continued) } \\
\hline Sample \# R & A A & Analyle & Unit & \begin{tabular}{|c|} 
Standard \\
$\%$
\end{tabular} & Blank & Result & Duplicate & Average & $\begin{array}{c}\text { RPD } \\
\%\end{array}$ & $\begin{array}{c}\text { Spk Rec } \\
\%\end{array}$ & Det Limit & $\begin{array}{c}\text { Count Err } \\
\%\end{array}$ \\
\hline S96T000538 & D & Magnesium-ICP-Acid Dil. & $\mu \mathrm{g} / \mathrm{mL}$ & 97.60 & $<1.00 \mathrm{e}-01$ & $<40.10$ & $<4.01 \mathrm{el}$ & $n / a$ & $\pi / a$ & 94.60 & 40.10 & $\mathbf{n} / \mathbf{a}$ \\
\hline S96T000538 & $\mathrm{D}$ & Manganese-ICP-Acid Dil. & $\mu \mathrm{g} / \mathrm{mL}$ & 100.6 & $<1.00 e-02$ & $<4.010$ & $<4.01<0$ & $\mathrm{n} / \mathrm{a}$ & $n / a$ & 98.10 & 4.010 & $\mathrm{n} / \mathbf{a}$ \\
\hline S96T000538 & D & Molybdenum-ICP-Acid Dil. & $\mu \mathrm{g} / \mathrm{mL}$ & 103.8 & $<5.00 \mathrm{e}-02$ & 29.30 & 25.00 & 27.15 & 15.8 & 101.5 & 20.10 & $n / a$ \\
\hline $596 \mathrm{T000538}$ & D & Sodium-ICP-Acid Dil. & $\mu \mathrm{g} / \mathrm{mL}$ & 98.20 & $<1.00 \mathrm{e}-01$ & $1.07 e+05$ & $9.68 c+04$ & $1.02 e+05$ & 10.0 & $n / 2$ & 40.10 & $\mathrm{n} / \mathbf{a}$ \\
\hline S96T000538 & D & Noodymium-ICP-Acid Dil. & $\mu \mathrm{g} / \mathrm{mL}$ & 105.2 & $<1.000-01$ & $<40.10$ & $<4.01 \mathrm{e} 1$ & $n / a$ & $n / a$ & 103.3 & 40.10 & $n / \mathbf{a}$ \\
\hline S96T000538 & $D$ & Nickel-ICP-Acid Dil. & $\mu \mathrm{g} / \mathrm{mL}$ & 101.6 & $<2.000-02$ & 18.40 & 15.70 & 17.05 & 15.8 & 100.0 & 8.020 & $n / a$ \\
\hline S96T000538 & D & Phosphorus-ICP-Acid Dil. & $\mu \mathrm{g} / \mathrm{mL}$ & 102.2 & $<2.00 \mathrm{e}-01$ & $3.24 e+02$ & 300.0 & 312.0 & 7.69 & 90.20 & 80.20 & $n / a$ \\
\hline S96T000538 & D & Lead-ICP-Acid Dil. & $\mu \mathrm{g} / \mathrm{mL}$ & 102.0 & $<1.000-01$ & $<40.10$ & $<4.01 \mathrm{el}$ & $n / \mathbf{a}$ & $n / a$ & 105.1 & 40.10 & $\mathrm{n} / \mathbf{2}$ \\
\hline S96T000538 & $D$ & Sulfur-ICP-Acid Dil. & $\mu \mathrm{g} / \mathrm{mL}$ & 98.80 & $<1,00 \mathrm{e}-01$ & $3.06 e+03$ & $2.71 e+03$ & $2.88 e+03$ & 12.1 & $n / a$ & 40.10 & $n / a$ \\
\hline S96T000538 & D & Antimony-ICP-Acid Dil. & $\mu \mathrm{g} / \mathrm{mL}$ & 96.20 & $<6.000-02$ & $<24.10$ & $<2.41 \mathrm{el}$ & $\mathbf{n} / \mathbf{a}$ & $n / a$ & 98.10 & 24.10 & $n / a$ \\
\hline S96T000538 & D & Selenium-ICP-Acid Dil. & $\mu \mathrm{g} / \mathrm{mL}$ & 98.40 & $<1.000-01$ & $<40.10$ & $<4.01 \mathrm{e} 1$ & $\mathbf{n} / \mathbf{a}$ & $n / \mathbf{n}$ & 101.6 & 40.10 & $n / a$ \\
\hline S96T000538 & D & Silicon-ICP-Acid Dil. & $\mu \mathrm{g} / \mathrm{mL}$ & 99.00 & $<5.00 \mathrm{e}-02$ & 26.20 & 23.00 & 24.60 & 13.0 & 98.30 & 20.10 & $n / a$ \\
\hline $596 \mathrm{~T} 000538$ & D & Samarium-ICP-Acid Dil. & $\mu \mathrm{g} / \mathrm{mL}$ & 100.4 & $<1.000-01$ & $<40.10$ & $<4.01 \mathrm{el}$ & $n / a$ & $n / \mathbf{a}$ & 98.60 & 40.10 & $n / a$ \\
\hline S96T000538 & $\mathrm{D}$ & Strontium-ICP-Acid Dil. & $\mu \mathrm{g} / \mathrm{mL}$ & 101.8 & $<1.00 \mathrm{e}-02$ & $<4.010$ & $<4.0100$ & $n / a$ & $n / a$ & 99.10 & 4.010 & $n / a$ \\
\hline S96T000538 & $\mathrm{D}$ & Titanium-ICP-Acid Dil. & $\mu \mathrm{g} / \mathrm{mL}$ & 100.4 & $<1.000-02$ & $<4.010$ & $<4.0100$ & $n / \mathbf{a}$ & $n / a$ & 98.60 & 4.010 & $n / a$ \\
\hline S96T000538 & D & Thallium-ICP-Acid Dil. & $\mu \mathrm{g} / \mathrm{mL}$ & 99.00 & $<2.00 c-01$ & $<80.20$ & $<8.02 \mathrm{el}$ & $\mathrm{n} / \mathbf{a}$ & $\mathbf{n} / \mathbf{a}$ & 97.60 & 80.20 & $n / a$ \\
\hline S96T000538 & D & Uranium-ICP-Acid Dil. & $\mu \mathrm{g} / \mathrm{mL}$ & 99.20 & $<5.00 \mathrm{e}-01$ & $1.87 e+03$ & $1.77 \mathrm{e}+03$ & $1.82 e+03$ & 5.49 & 56.65 & 200.0 & $n / a$ \\
\hline S96T000538 & D & Vanadium-ICP-Acid Dil. & $\mu \mathrm{g} / \mathrm{mL}$ & 103.4 & $<5.000-02$ & $<20.00$ & $<2.00 \mathrm{el}$ & $n / \mathbf{a}$ & $\mathbf{n} / \mathbf{a}$ & 102.3 & 20.10 & $n / a$ \\
\hline S96T000538 & D & Zinc-ICP-Acid Dil. & $\mu \mathrm{g} / \mathrm{mL}$ & 101.6 & $<1.00 \mathrm{e}-02$ & 5.090 & 4.050 & 4.570 & 22.8 & 101.8 & 4.010 & $n / \mathbf{a}$ \\
\hline S96T000538 & D & Zirconium-ICP-Acid Dil. & $\mu \mathrm{g} / \mathrm{mL}$ & 102.0 & $<1.00 \mathrm{e}-02$ & $4.45 e+02$ & 404.0 & 424.5 & 9.66 & 82.70 & 4.010 & $n / 2$ \\
\hline S96T000538 & & $\begin{array}{l}\text { Fluoride-IC-Dionex } \\
4000 \mathrm{i} / 4500\end{array}$ & $\mu \mathrm{g} / \mathrm{mL}$ & 100.7 & $<1.30<-02$ & $3.17 e+02$ & 347.0 & 332.0 & 9.04 & 96.61 & 132.6 & $n / a$ \\
\hline
\end{tabular}




\begin{tabular}{|c|c|c|c|c|c|c|c|c|c|c|c|c|}
\hline & \multicolumn{12}{|c|}{ SEGMENT PORTION: Supernate (Continued) } \\
\hline Sample $\mathrm{R}$ & A \# & Analyte & Unit & $\begin{array}{c}\text { Standard } \\
\times\end{array}$ & Blank & Result & Duplicate & Average & $\begin{array}{c}\text { RPD } \\
\%\end{array}$ & \begin{tabular}{|c|} 
Spk Rec \\
$\%$
\end{tabular} & Det Limit & $\begin{array}{c}\text { Count Ext } \\
\%\end{array}$ \\
\hline$\$ 967000538$ & & $\begin{array}{l}\text { Chloride-IC-Dionex } \\
4000 \mathrm{i} / 4500\end{array}$ & $\mu \mathrm{g} / \mathrm{mL}$ & 102.5 & $5.00 \mathrm{e}-02$ & $2.48 e+02$ & 428.0 & 337.9 & 53.3 & 102.0 & 173.4 & $\mathrm{n} / \mathbf{a}$ \\
\hline \$96T000538 & & Nitrite-IC-Dionex $4000 \mathrm{j} / 4500$ & $\mu \mathrm{g} / \mathrm{mL}$ & 103.5 & $<1.07 \mathrm{e}-01$ & $2.91 \mathrm{e}+04$ & $2.87 e+04$ & $2.89 e+04$ & 1.38 & 106.3 & $1.09 c+03$ & $\mathrm{n} / \mathbf{a}$ \\
\hline $596 \mathrm{~T} 000538$ & & Nitrate-IC-Dionex $4000 \mathrm{i} / 4500$ & $\mu \mathrm{g} / \mathrm{mL}$ & 102.1 & $<1.40 \mathrm{e}-0 \mathrm{I}$ & $2.04 \mathrm{e}+03$ & $1.58 e+03$ & $1.81 \mathrm{e}+03$ & 25.4 & 103.1 & $1.43 e+03$ & $n / a$ \\
\hline S96T000538 & & $\begin{array}{l}\text { Phosphate-IC-Dionex } \\
4000 \mathrm{i} / 4500\end{array}$ & $\mu \mathrm{g} / \mathrm{mL}$ & 103.1 & $<1.19 \mathrm{e}-01$ & $<1.21 \mathrm{e}+03$ & $<1.21 \mathrm{e} 3$ & $\mathrm{n} / \mathrm{a}$ & $\mathrm{n} / \mathrm{a}$ & 103.7 & $1.21 c+03$ & $n / a$ \\
\hline S96T000538 & & \begin{tabular}{|l} 
Sulfate by IC-Dionex \\
$4000 \mathrm{i} / 4500$
\end{tabular} & $\mu \mathrm{g} / \mathrm{mL}$ & 99.53 & $<1.36 \mathrm{e}-01$ & $7.46 \mathrm{e}+03$ & $7.86 e+03$ & $7.66 e+03$ & 5.22 & 101.0 & $1.39 c+03$ & $n / a$ \\
\hline S96T000538 & & Oxalate by IC Dionex $4000 \mathrm{i}$ & $\mu \mathrm{g} / \mathrm{mL}$ & 105.3 & $<1.05 \mathrm{e}-01$ & $3.65 e+03$ & $3.70 e+03$ & $3.68 e+03$ & 1.36 & 108.4 & $1.07 e+03$ & $n / a$ \\
\hline S96T000539 & & Technetium-99 Liq. Scint. & $\mu \mathrm{Ci} / \mathrm{mL}$ & 101.8 & $<3.54 \mathrm{e}-03$ & $8.52 \mathrm{e}-02$ & $9.23 \mathrm{e}-02$ & $8.87 e-02$ & 8.00 & $n / a$ & $4.00 \mathrm{e}-03$ & $3.03 \mathrm{E}+00$ \\
\hline $596 \mathrm{~T} 000539$ & & Strontium-89/90 High Level & $\mu \mathrm{Ci} / \mathrm{mL}$ & 95.12 & $8.00 \mathrm{e}-03$ & $3.69 \mathrm{e}-01$ & $3.62 e-01$ & $3.65 \mathrm{e}-01$ & 1.92 & $n / a$ & $2.00 e-03$ & $3.46 \mathrm{E}+00$ \\
\hline S96T000539 & & $\begin{array}{l}\text { Pu-239/240 by TRU-SPEC } \\
\text { Resin }\end{array}$ & $\mu \mathrm{Ci} / \mathrm{mL}$ & 88.28 & $<3.12 \mathrm{e}-03$ & $7.40 \mathrm{e}-01$ & $6.92 \mathrm{e}-01$ & $7.16 e-01$ & 6.70 & $\pi / 2$ & $3.10 \mathrm{e}-02$ & $1.65 \mathrm{E}+00$ \\
\hline $596 \mathrm{~T} 000539$ & & Cobalt- 60 by GEA & $\mu \mathrm{Ci} / \mathrm{mL}$ & 99.23 & $<1.99 \mathrm{e}-05$ & $<5.71 \mathrm{e}-03$ & $<6.13 \mathrm{e}-3$ & $\mathrm{n} / \mathrm{a}$ & $n / \mathbf{a}$ & $n / a$ & $6.000-03$ & $\mathrm{n} / \mathbf{a}$ \\
\hline S96T000539 & & Cesium-137 by GEA & $\mu \mathrm{Ci} / \mathrm{mL}$ & 101.5 & $<5.81 \mathrm{e}-05$ & $1.08 \mathrm{e}+02$ & 107.0 & 107.5 & 0.93 & $n / a$ & $n / \mathbf{a}$ & 0.210 \\
\hline S96T000539 & & Am-241 by Extraction & $\mu \mathrm{Ci} / \mathrm{mL}$ & 80.13 & $<1.15 \mathrm{e}-02$ & $1.50 \mathrm{e}-02$ & $1.21 \mathrm{e}-02$ & $1.35 \mathrm{e}-02$ & 21.4 & $n / \mathbf{a}$ & $1.20 \mathrm{c}-02$ & $4.65 \mathrm{E}+00$ \\
\hline S96T000539 & & Alpha in Liquid Samples & $\mu \mathrm{Ci} / \mathrm{mL}$ & 102.6 & $<3.84 e-03$ & 1.150 & 1.140 & 1.145 & 0.87 & 108.9 & $1.00 \mathrm{e}-02$ & $5.03 \mathrm{E}+\infty 0$ \\
\hline
\end{tabular}




\begin{tabular}{|c|c|c|c|c|c|c|c|c|c|c|c|c|}
\hline \multicolumn{13}{|c|}{$\begin{array}{l}\text { Table A.2-1: Interim Results for Tank C-106 Grab Samples. } \\
\text { C-106 GRAB }\end{array}$} \\
\hline \multicolumn{13}{|c|}{ SEGMENT : 6 6C-96-7 } \\
\hline \multicolumn{13}{|c|}{ SEGMENT PORTION: Centrifuged Solids (Grab Sample) } \\
\hline Sample \# R & $A \#$ & Analyte & Unit & $\begin{array}{c}\text { Standard } \\
\%\end{array}$ & Blank & Result & Duplicate & Average & $\begin{array}{c}\text { RPD } \\
\%\end{array}$ & $\begin{array}{c}\text { Spk Rec } \\
\%\end{array}$ & Det Limit & $\begin{array}{c}\text { Count Err } \\
\%\end{array}$ \\
\hline S96T000542 & & Bulk Density of Sample & $\mathrm{g} / \mathrm{mL}$ & $n / a$ & $\mathrm{n} / \mathbf{a}$ & 1.710 & $n / \mathbf{a}$ & $n / \mathbf{a}$ & $n / \mathbf{a}$ & $n / a$ & $5.000-01$ & $n / \mathbf{a}$ \\
\hline S96T000542 & & DSC Exotherm using Menter & Joules/g & 113.5 & $\mathrm{n} / \mathrm{a}$ & $1.12 e+02$ & 89.10 & 100.5 & 22.8 & $\pi / \mathbf{a}$ & $n / \mathbf{a}$ & $\mathrm{n} / \mathrm{a}$ \\
\hline$\$ 96 \mathrm{~T} 000542$ & & $\begin{array}{l}\text { DSC Exotherm Dry } \\
\text { Calculated }\end{array}$ & Joules/g Dry & $n / \mathbf{a}$ & $n / \mathbf{a}$ & $1.22 \mathrm{e}+02$ & 97.14 & 109.6 & 22.8 & $n / a$ & $n / a$ & $\mathrm{n} / \mathrm{a}$ \\
\hline S96T000542 & & $\begin{array}{l}\text { \%o Water by TGA on Perkin } \\
\text { Elmer }\end{array}$ & $\%$ & 98.68 & $n / a$ & 8.040 & 8.510 & 8.275 & 5.68 & $n / a$ & $n / \mathbf{a}$ & $n / \mathbf{a}$ \\
\hline S96T000542 & & Volume \% Solids & $\%$ & $\mathrm{n} / \mathrm{a}$ & $\mathrm{n} / \mathbf{a}$ & 69.50 & $n / a$ & $n / 2$ & $n / a$ & $n / a$ & $\mathrm{n} / \mathrm{a}$ & $n / \mathbf{a}$ \\
\hline S96T000542 & & \$o Water by Gravimetric & $\%$ & 98.14 & $n / \mathbf{a}$ & 9.800 & 10.00 & 9.900 & 0.22 & $\mathrm{n} / \mathbf{a}$ & $1.00=-02$ & $n / a$ \\
\hline \multicolumn{13}{|c|}{ Control Sample: Control Sample } \\
\hline S96T000543 & & $\begin{array}{l}\text { DSC Exotherm Dry } \\
\text { Calculated }\end{array}$ & Joules/g Dry & $n / a$ & $n / \mathbf{a}$ & $0.00 e+\infty$ & $0.00 e+00$ & $0.00 c+\infty$ & 0.00 & $n / \mathbf{a}$ & $n / a$ & $n / a$ \\
\hline$\$ 96 \mathrm{TO00543}$ & & $\begin{array}{l}\text { DSC Exotherm on Perkin } \\
\text { Elmer }\end{array}$ & Joules/g & 95.82 & $n / a$ & $0.00 e+00$ & $0.00 e+00$ & $0.00 e+\infty$ & 0.00 & $n / a$ & $\mathrm{n} / \mathrm{a}$ & $n / a$ \\
\hline S96T000543 & & $\begin{array}{l}\% \text { Water by TGA on Perkin } \\
\text { Elmer }\end{array}$ & $x$ & 99.41 & $n / \mathbf{a}$ & 29.76 & 32.47 & 31.12 & 8.71 & $n / a$ & $n / 2$ & $n / a$ \\
\hline S96T000546 & $\mathbf{F}$ & Technetium-99 Liq. Scint. & $\mu \mathrm{Ci} / \mathrm{g}$ & 99.47 & $<3.58 \mathrm{e}-02$ & $5.51 \mathrm{e}-02$ & $4.48 \mathrm{e}-02$ & $5.000-02$ & 20.6 & $n / a$ & $3.500-02$ & $5.81 \mathrm{E}+00$ \\
\hline $596 \mathrm{~T} 000546$ & $\mathrm{~F}$ & Strontium-89/90 High Level & $\mu \mathrm{Ci} / \mathrm{g}$ & 92.68 & $6.20 \mathrm{e}-02$ & $3.32 e+02$ & 342.0 & 337.0 & 2.97 & $n / a$ & $5.300-02$ & $5.19 \mathrm{E}-01$ \\
\hline S96T000546 & $F$ & $\begin{array}{l}\text { Pu-239/240 by TRU-SPEC } \\
\text { Resin }\end{array}$ & $\mu \mathrm{Ci} / \mathrm{g}$ & 92.13 & $<3.430-02$ & 1.520 & 1.390 & 1.455 & 8.93 & $n / \mathbf{a}$ & $1.13 e-01$ & $2.03 E+\infty$ \\
\hline S96T000546 & $\bar{F}$ & Cobalt-60 by GEA & $\mu \mathrm{Ci} / \mathrm{g}$ & 96.66 & $<1.52 e-01$ & $<2.33 \mathrm{c}-01$ & $<2.27 e-1$ & $\mathrm{n} / \mathbf{a}$ & $a / 2$ & $n / \mathbf{a}$ & $2.33 \mathrm{c}-01$ & $n / \mathbf{a}$ \\
\hline S96T000546 & $\mathrm{F}$ & Cesium- 137 by GEA & $\mu \mathrm{C} \mathbf{i} / \mathrm{g}$ & 96.08 & $<2.04 \mathrm{e}-01$ & $4.03 e+02$ & 417.0 & 409.9 & 3.41 & $n / a$ & $n / 2$ & 0.580 \\
\hline S96T000546 & $F$ & Am-241 by Extraction & $\mu \mathrm{C} i / g$ & 106.1 & $<2.54 \mathrm{c}-02$ & 1.010 & 1.230 & 1.120 & 19.6 & $n / a$ & $8.100-02$ & 3.4 \\
\hline
\end{tabular}


Table A.2-1: Interim Results for Tank C-106 Grab Samples. C-106 GRAB

Control Sample: Control Sample (Continued)

\begin{tabular}{|c|c|c|c|c|c|c|c|c|c|c|c|c|}
\hline Sample \# R & $A \#$ & Analyte & Unit & $\begin{array}{c}\text { Standard } \\
\%\end{array}$ & Blank & Result & Duplicate & Average & $\begin{array}{c}\text { RPD } \\
\%\end{array}$ & $\begin{array}{c}\text { Spk Rec } \\
\%\end{array}$ & Det Limit & $\begin{array}{c}\text { Count Err } \\
\%\end{array}$ \\
\hline S96T000546 & $\mathbf{F}$ & Alpha of Digested Solid & $\mu \mathrm{Ci} / \mathrm{g}$ & 118.0 & $<5.57 \mathrm{e}-02$ & 2.880 & 2.570 & 2.725 & 11.4 & 106.4 & $7.200-02$ & $1.03 E+01$ \\
\hline
\end{tabular}

Decanted Supermate (Liquid Grab Sludge): Decanted Supernate (Liquid Grab Sludge)

\begin{tabular}{|c|c|c|c|c|c|c|c|c|c|c|c|}
\hline S96T000544 & pH Direct & $\mathrm{pH}$ & $n / \mathbf{a}$ & $n / a$ & 10.09 & $n / a$ & $\mathrm{n} / \mathrm{a}$ & $n / a$ & $n / a$ & $1.00=02$ & $n / a$ \\
\hline S96T000544 & Specific Gravity & Sp.G. & 101.1 & $n / a$ & 1.200 & 1.194 & 1.197 & 0.50 & $\mathrm{n} / \mathrm{a}$ & $1.00=03$ & $n / a$ \\
\hline S96T000544 & $\begin{array}{l}\text { Tot. Organic Carbon by } \\
\text { Coul. }\end{array}$ & $\mu \mathrm{g} / \mathrm{mL}$ & 100.0 & $1.00 \mathrm{e}-01$ & $2.07 e+03$ & $2.02 e+03$ & $2.04 e+03$ & 2.44 & 100.0 & 55.00 & $n / a$ \\
\hline S96T000544 & $\%$ Water by Gravimetric & $\%$ & 98.65 & $n / a$ & 78.80 & 78.80 & 78.80 & 0.00 & $n / \mathbf{a}$ & $1.00=-02$ & $n / \mathrm{s}$ \\
\hline S96T000544 & Strontium-89/90 High Level & $\mu \mathrm{Ci} / \mathrm{mL}$ & 101.6 & $<2.06 e-03$ & $9.68 \mathrm{e}-01$ & $8.93 e-01$ & $9.30 c-01$ & 8.06 & $n / \mathfrak{a}$ & $4.00=-03$ & $2.08 \mathrm{E}+00$ \\
\hline \$96T000544 & $\begin{array}{l}\text { Pu-239/240 by TRU-SPEC } \\
\text { Resin }\end{array}$ & $\mu \mathrm{Ci} / \mathrm{mL}$ & 92.39 & $<3.82 \mathrm{e}-03$ & $7.69 e-01$ & $7.56 c-01$ & $7.62 \mathrm{e}-01$ & 1.70 & $\mathbf{n} / \mathbf{a}$ & $3.60=-02$ & $1.96 \mathrm{E}+00$ \\
\hline
\end{tabular}

Filtered Centrifuged Solids: Filtered Centrifuged Solids

\begin{tabular}{|c|c|c|c|c|c|c|c|c|c|c|c|c|}
\hline \$96T000551 & & DSC Exotherm using Mett]cr & Joules/g & 113.5 & $n / a$ & $2.87 e+02$ & 279.9 & 283.4 & 2.47 & $n / \mathbf{a}$ & $n / a$ & $n / a$ \\
\hline S96T000551 & & $\begin{array}{l}\text { DSC Exotherm Dry } \\
\text { Calculated }\end{array}$ & Joules/g Dry & $n / a$ & $n / a$ & $3.29 \mathrm{e}+02$ & 320.9 & 324.9 & 2.46 & $\mathrm{n} / \mathrm{a}$ & $n / \mathfrak{a}$ & $n / a$ \\
\hline S96T000551 & & $\begin{array}{l}\% \text { Water by TGA using } \\
\text { Mettler }\end{array}$ & $\%$ & 102.2 & $n / a$ & 9.440 & 16.11 & 12.77 & 52.2 & $\mathrm{n} / \mathbf{a}$ & $n / a$ & $n / a$ \\
\hline S96T000552 & & TIC by Acid/Coulometry & $\mu \mathrm{g} / \mathrm{g}$ & 97.84 & $8.00 c-01$ & $2.56 \mathrm{e}+04$ & $2.76 e+04$ & $2.66 \mathrm{e}+04$ & 7.52 & $\mathbf{n} / \mathbf{a}$ & 5.000 & $n / a$ \\
\hline$\$ 96 \mathrm{~T} 000552$ & & $\begin{array}{l}\text { Toc by Persulfatel } \\
\text { Coulometry }\end{array}$ & $\mu \mathrm{g} / \mathrm{g}$ & 92.03 & 3.100 & $2.47 e+04$ & $2.92 c+04$ & $2.70 e+04$ & 16.7 & $n / a$ & 40.00 & $n / a$ \\
\hline S96T000553 & & $\%$ Water by Gravimetric & $\%$ & 98.14 & $n / a$ & 18.90 & 19.20 & 19.05 & 0.38 & $n / a$ & $1.00=-02$ & $n / a$ \\
\hline \$96T000554 & & pH on SST Samples & $\mathrm{pH}$ & $n / a$ & $n / a$ & 10.40 & 10.50 & 10.45 & 0.96 & $n / a$ & $1.000-02$ & $n / a$ \\
\hline \$96T000555 & $\mathbf{F}$ & Technetium-99 Liq. Scint. & $\mu \mathrm{Ci} / \mathrm{g}$ & 99.47 & $<3.58 \mathrm{e}-02$ & $4.09 \mathrm{e}-02$ & $<3.53 \mathrm{E}-2$ & $n / a$ & $n / a$ & $n / a$ & $3.700-02$ & $6.26 \mathrm{E}+\infty 0$ \\
\hline S96T000555 & $\mathbf{F}$ & Strontium-89/90 High Level & $\mu \mathrm{Ci} / \mathrm{g}$ & 92.68 & $6.20=-02$ & $5.19 e+02$ & 523.0 & 521.0 & 0.77 & nia & $1.14 \mathrm{e}-01$ & $6.08 \mathrm{E}-01$ \\
\hline
\end{tabular}




\begin{tabular}{|c|c|c|c|c|c|c|c|c|c|c|c|c|}
\hline \multicolumn{13}{|c|}{ Filtered Centrifuged Solids: Filtered Centrifuged Solids (Continued) } \\
\hline Sampie \# R & A\# & Analyte & Unit & 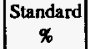 & Blank & Result & Duplicate & Average & $\begin{array}{l}\text { RPD } \\
\%\end{array}$ & $\begin{array}{c}\text { Spk Rec } \\
\%\end{array}$ & Det Limit & $\begin{array}{c}\text { Count Err } \\
\%\end{array}$ \\
\hline S96T000555 & $\mathbf{F}$ & \begin{tabular}{|l} 
Pu-239/240 by TRU-SPEC \\
Resin
\end{tabular} & $\mu \mathrm{Ci} / \mathrm{g}$ & 98.69 & $<3.56 e-02$ & 1.320 & 1.280 & 1.300 & 3.08 & $n / \mathbf{a}$ & $8.900-02$ & $2.09 \mathrm{E}+00$ \\
\hline$\$ 96 T 000555$ & $\mathbf{F}$ & Cobalt -60 by GEA & $\mu \mathrm{Ci} / \mathrm{g}$ & 98.05 & $<4.73 \mathrm{e}-01$ & $0.00 \mathrm{e}+\infty$ & $<5.71 e-1$ & $\mathbf{n} / \mathbf{a}$ & $\mathbf{n} / \mathbf{a}$ & $n / 2$ & $\mathbf{n} / \mathbf{a}$ & $\mathbf{n} / \mathbf{a}$ \\
\hline S96T000555 & $\mathbf{F}$ & Cesium- 137 by GEA & $\mu \mathrm{Ci} / \mathrm{g}$ & 98.56 & $<9.17 \mathrm{e}-01$ & $5.96 e+02$ & 622.0 & 609.0 & 4.27 & $n / \mathbf{a}$ & $\mathbf{n} / \mathbf{a}$ & 17.0 \\
\hline S96T000555 & $\mathbf{F}$ & Am-241 by Extraction & $\mu \mathrm{Ci} / \mathrm{g}$ & 106.1 & $<2.540-02$ & 1.330 & 1.220 & 1.275 & 8.63 & $\mathrm{n} / \mathrm{a}$ & $9.60 \mathrm{e}-02$ & 2.8 \\
\hline S967000555 & $\mathbf{F}$ & Alpha of Digested Solid & $\mu \mathrm{Ci} / \mathrm{g}$ & 118.0 & $<5.57 \mathrm{e}-02$ & 3.330 & 3.060 & 3.195 & 8.45 & 109.7 & $7.70 \mathrm{e}-02$ & $9.94 E+00$ \\
\hline S96T000556 & A & Silver-ICP-Acid Digest & $\mu \mathrm{g} / \mathrm{g}$ & 91.90 & $<1.00 \mathrm{e}-02$ & $2.77 e+03$ & $2.02 e+03$ & $2.40 e+03$ & 31.3 & $\mathrm{n} / \mathrm{a}$ & 11.00 & $\mathbf{n} / \mathbf{a}$ \\
\hline S96T000556 & A & Aluminum-ICP-Acid Digest & $\mu \mathrm{g} / \mathrm{g}$ & 96.60 & $1.18 \mathrm{e}-01$ & $5.17 e+04$ & $4.42 e+04$ & $4.80 e+04$ & 15.6 & $1.38 e+03$ & 54.80 & $\mathbf{n} / \mathbf{a}$ \\
\hline$\$ 96 \mathrm{~T} 000556$ & A & Boron-ICP-Acid Digest & $\mu \mathrm{g} / \mathrm{g}$ & 108.8 & $5.40 \mathrm{e}-01$ & $<54.80$ & $<4.72 \mathrm{el}$ & $\mathbf{n} / \mathbf{a}$ & $\mathbf{n} / \mathbf{a}$ & 99.40 & 54.80 & $n / \mathbf{a}$ \\
\hline S96T000556 & A & Barium-ICP-Acid Digest & $\mu \mathrm{g} / \mathrm{g}$ & 97.60 & $<5.00 \mathrm{c}-02$ & $3.04 e+02$ & 260.0 & 282.0 & 15.6 & 102.2 & 54.80 & $\mathbf{n} / \mathbf{a}$ \\
\hline S96T000556 & $A$ & Beryllium-ICP-Acid Digest & $\mu \mathrm{g} / \mathrm{g}$ & 103.0 & $<5.00 \mathrm{e}-03$ & $<5.480$ & $<4.72 \mathrm{e} 0$ & n/a & $\mathbf{n} / \mathbf{a}$ & 98.40 & 5.480 & $\mathbf{n} / \mathbf{a}$ \\
\hline \$96T000556 & A & Bismuth-ICP-AcidDigest & $\mu g / g$ & 92.40 & $<1.000-01$ & $<1.10 e+02$ & $<9.43 \mathrm{el}$ & $\mathbf{n} / \mathbf{a}$ & $\mathbf{n} / \mathbf{a}$ & 89.80 & 110.0 & $n / \mathbf{a}$ \\
\hline S96T000556 & A & Calcium-ICP-AcidDigest & $\mu \mathrm{g} / \mathrm{g}$ & 100.2 & $4.59 e-01$ & $1.33 e+03$ & $1.12 e+03$ & $1.22 e+03$ & 17.1 & 91.02 & 110.0 & n/a \\
\hline S96T000556 & $A$ & Cadmium-ICP-Acid Digest & $\mu \mathrm{g} / \mathrm{g}$ & 94.60 & $<5.000-03$ & 33.30 & 27.10 & 30.20 & 20.5 & 94.16 & 5.480 & $n / \mathbf{a}$ \\
\hline S96T000556 & $A$ & Cerium-ICP-Acid Digest & $\mu g / g$ & 100.0 & $<1.00 \mathrm{e}-01$ & $1.78 c+02$ & 174.0 & 176.0 & 2.27 & 106.1 & 110.0 & $\mathrm{n} / \mathbf{a}$ \\
\hline S96T000556 & A & Cobalt-ICP-Acid Digest & $\mu \mathrm{g} / \mathrm{g}$ & 98.40 & $<2.000-02$ & $<<21.90$ & $<1.89 \mathrm{el}$ & $n / a$ & $\mathrm{n} / \mathbf{a}$ & 97.20 & 21.90 & $\mathrm{n} / \mathrm{a}$ \\
\hline S96T000556 & A & Chromium-ICP-Acid Digest & $\mu \mathrm{g} / \mathrm{g}$ & 97.00 & 1.700 .02 & $6.45 e+02$ & 552.0 & 598.5 & 15.5 & 107.3 & 11.00 & $m / 2$ \\
\hline \$96T000556 & A & Copper-ICP-Acid Digest & $\mu \mathrm{g} / \mathrm{g}$ & 92.80 & $2.60 \mathrm{e}-02$ & 89.70 & 76.70 & 83.20 & 15.6 & 94.02 & 11.00 & $\mathrm{n} / \mathrm{a}$ \\
\hline $596 \mathrm{~T} 000556$ & A & Iron-ICP-Acid Digest & $\mu \mathrm{g} / \mathrm{g}$ & 97.60 & $7.00 \mathrm{e}-02$ & $6.87 e+04$ & $5.86 e+04$ & $6.36 e+04$ & 15.9 & $1.65 e+03$ & 54.80 & $n / a$ \\
\hline $596 \mathrm{~T} 000556$ & A & Potassium-ICP-Acid Digest & $\mu g / g$ & 98.80 & $<5.00=01$ & $6.43 e+02$ & 588.0 & 615.5 & 8.94 & 118.1 & 548.0 & $\mathbf{n} / \mathbf{a}$ \\
\hline S96T000556 & A & Lanthanum-ICP-Acid Digest & $\mu \mathrm{g} / \mathrm{g}$ & 98.20 & $<5.000-02$ & 74.80 & 60.50 & 67.65 & 21.1 & 97.36 & 54.80 & $\mathrm{n} / \mathbf{a}$ \\
\hline
\end{tabular}


Table A.2-1: Interim Results for Tank C-106 Grab Samples.

C-106 GRAB

Filtered Centrifuged Solids: Filtered Centrifuged Solids (Continued)

\begin{tabular}{|c|c|c|c|c|c|c|c|c|c|c|c|c|}
\hline Sample \# R & A\# & Analyte & Unit & $\begin{array}{c}\text { Standard } \\
\%\end{array}$ & Blank & Result & Duplicate & Average & $\begin{array}{c}\text { RPD } \\
\%\end{array}$ & $\underset{\%}{\text { Spk Rec }}$ & Det Limit & $\begin{array}{c}\text { Count Err } \\
\$\end{array}$ \\
\hline S96T000556 & A & Lithium-ICP-Acid Digest & $\mu g / g$ & 95.80 & $<1.00 e-02$ & $<11.00$ & $<9.43 \mathrm{ec}$ & $\mathbf{n} / \mathbf{a}$ & $\mathrm{n} / \mathrm{a}$ & 93.80 & 11.00 & $n / a$ \\
\hline S96T000556 & A & Magnesium-ICP-Acid Digest & $\mu \mathrm{g} / \mathrm{g}$ & 94.60 & $<1.00 e-01$ & $2.19 e+02$ & 187.0 & 203.0 & 15.8 & 95.58 & 110.0 & $\mathrm{n} / \mathrm{a}$ \\
\hline S96T000556 & A & Manganese-ICP-Acid Digest & $\mu g / g$ & 96.60 & $<1.00 c-02$ & $1.86 e+03$ & $1.59 e+03$ & $1.72 e+03$ & 15.7 & 136.5 & 11.00 & $n / a$ \\
\hline S96T000556 & $A$ & $\begin{array}{l}\text { Molybdenum-ICP-Acid } \\
\text { Digest }\end{array}$ & $\mu \mathrm{g} / \mathrm{g}$ & 97.60 & $<5.00 \mathrm{e}-02$ & $<54.80$ & $<4.72 \mathrm{el}$ & $n / a$ & $n / \mathbf{a}$ & 96.00 & 54.80 & $\mathrm{n} / \mathrm{a}$ \\
\hline S96T000556 & $\mathbf{A}$ & Sodium-ICP-Acid Digest & $\mu \mathrm{g} / \mathrm{g}$ & 109.0 & $7.70 \mathrm{er}-01$ & $1.61 e+05$ & $1.37 e+05$ & $1.49 e+05$ & 16.1 & $1.69 e+03$ & 110.0 & $n / 2$ \\
\hline S96T000556 & A & Neodymium-ICP-Acid Digest & $\mu \mathrm{g} / \mathrm{g}$ & 98.00 & $<1.00 \mathrm{e}-01$ & $1.39 e+02$ & 127.0 & 133.0 & 9.02 & 102.7 & 110.0 & $n / 2$ \\
\hline S96T000556 & A & Nickel-ICP-Acid Digest & $\mu g / g$ & 97.20 & $<2.00 \mathrm{e}-02$ & $6.45 e+02$ & 550.0 & 597.5 & 15.9 & 109.8 & 21.90 & $\mathrm{n} / \mathrm{a}$ \\
\hline$\$ 96 \mathrm{~T} 000556$ & A & Phosphorus-ICP-Acid Digest & $\mu \mathrm{g} / \mathrm{g}$ & 99.80 & $<2.00 \mathrm{e}-01$ & $2.58 \mathrm{e}+03$ & $2.20 e+03$ & $2.39 e+03$ & 15.9 & 148.5 & 219.0 & $n / a$ \\
\hline S96T000556 & A & Lead-ICP-Acid Digest & $\mu \mathrm{g} / \mathrm{g}$ & 91.60 & $<1.00 \mathrm{e}-01$ & $2.49 e+03$ & $2.15 \mathrm{e}+03$ & $2.32 e+03$ & 14.7 & 148.3 & 110.0 & $\mathrm{n} / \mathrm{a}$ \\
\hline S96T000556 & A & Sulfur-ICP-Acid Digest & $\mu \mathrm{g} / \mathrm{g}$ & 95.60 & $<1.00 e-01$ & $1.39 e+03$ & $1.19 \mathrm{e}+03$ & $1.29 e+03$ & 15.5 & 121.2 & 110.0 & $n / a$ \\
\hline S96T000556 & $\bar{A}$ & Antimony-ICP-Acid Digest & $\mu \mathrm{g} / \mathrm{g}$ & 96.60 & $<6.00 \mathrm{e}-02$ & $<65.70$ & $<5.66 \mathrm{el}$ & $n / a$ & $n / a$ & 97.80 & 65.70 & $n / \mathfrak{a}$ \\
\hline S96T000556 & $A$ & Selenium-ICP-Acid Digest & $\mu \mathrm{g} / \mathrm{g}$ & 97.80 & $<1.00 \mathrm{e}-01$ & $<1.10 e+02$ & $<9.43 \mathrm{el}$ & $\mathbf{n} / \mathbf{a}$ & $n / a$ & 100.0 & 110.0 & $n / a$ \\
\hline S96T000556 & A & Silicon-ICP-Acid Digest & $\mu g / g$ & 135.2 & $2.27 e-01$ & $2.87 e+04$ & $2.47 e+04$ & $2.67 e+04$ & 15.0 & 736.3 & 54.80 & $\mathrm{n} / \mathbf{a}$ \\
\hline S96T000556 & A & Samarium-ICP-Acid Digest & $\mu \mathrm{g} / \mathrm{g}$ & 99.80 & $<1.00 \mathrm{e}-01$ & $<1.10 e+02$ & $<9.43 \mathrm{el}$ & $\mathrm{n} / \mathbf{a}$ & $n / a$ & 101.4 & 110.0 & $n / a$ \\
\hline S96T000556 & A & Strontium-ICP-Acid Digest & $\mu \mathrm{g} / \mathrm{g}$ & 97.00 & $<1.00 e-02$ & 21.10 & 17.90 & 19.50 & 16.4 & 95.68 & 11.00 & $n / a$ \\
\hline S96T000556 & A & Titanium-ICP-Acid Digest & $\mu g / g$ & 91.60 & $<1.000-02$ & $1.20 e+02$ & 102.0 & 111.0 & 16.2 & 92.06 & 11.00 & $n / a$ \\
\hline 596T000556 & A & Thallium-ICP-Acid Digesi & $\mu g / g$ & 88.60 & $<2.002-01$ & $<2.19 c+02$ & $<1.89 e 2$ & $n+\dot{a}$ & n'a & 88.60 & 219.0 & $\mathbf{n}^{\prime \prime}$ \\
\hline S96T000556 & A & Uranium-ICP-AcidDigest & $\mu g / g$ & 94.40 & $<5.00 \mathrm{e}-01$ & $8.30 e+02$ & 686.0 & 758.0 & 19.0 & 94.13 & 548.0 & $n / a$ \\
\hline S96T000556 & A & Vanadium-ICP-Acid Digest & $\mu \mathrm{g} / \mathrm{g}$ & 96.40 & $<5.00 \mathrm{e}-02$ & $<54.80$ & $<4.72 \mathrm{el}$ & $\mathbf{n} / \mathbf{a}$ & $n / \mathbf{a}$ & 95.80 & 54.80 & $n / \mathbf{a}$ \\
\hline S96T000556 & A & Zinc-ICP-Acid Digest & $\mu g / g$ & 92.60 & $2.50 \mathrm{e}-02$ & 39.60 & 35.20 & 37.40 & 11.8 & 93.38 & 11.00 & $n / a$ \\
\hline S96T000556 & $A$ & Zirconium-ICP-Acid Digest & $\mu g / g$ & 104.2 & $<1.00 e-02$ & 49.30 & 39.40 & 44.35 & 22.3 & 151.7 & 11.00 & $\mathrm{n} / \mathrm{a}$ \\
\hline
\end{tabular}




\begin{tabular}{|c|c|c|c|c|c|c|c|c|c|c|c|c|}
\hline \multicolumn{13}{|c|}{ Filtered Centrifuged Solids: Filtered Centrifuged Solids (Continued) } \\
\hline Sample \# R & A\# & Analyte & Unit & $\begin{array}{c}\text { Standard } \\
\%\end{array}$ & Blank & Result & Duplicate & Average & $\begin{array}{c}\text { RPD } \\
\%\end{array}$ & $\begin{array}{c}\text { Spk Rec } \\
\%\end{array}$ & Det Limit & $\underset{\%}{\text { Count Err }}$ \\
\hline S96T000557 & w & $\begin{array}{l}\text { Fluoride-IC-Dionex } \\
4000 \mathrm{i} / 4500\end{array}$ & $\mu g / g$ & 96.10 & $<1.30 \mathrm{e}-02$ & $2.09 e+02$ & 198.0 & 203.6 & 5.41 & 109.0 & 50.69 & n/a \\
\hline S96T000557 & $\mathbf{w}$ & $\begin{array}{l}\text { Chloride-IC-Dionex } \\
4000 \mathrm{i} / 4500\end{array}$ & $\mu \mathrm{g} / \mathrm{g}$ & 99.11 & $3.30 \mathrm{e}-02$ & $1.72 e+02$ & 169.0 & 170.4 & 1.76 & 99.37 & 66.28 & $n / \mathbf{a}$ \\
\hline S96T000557 & $\mathbf{W}$ & Nitrite-IC-Dionex $4000 \mathrm{i} / 4500$ & $\mu \mathrm{g} / \mathrm{g}$ & 97.74 & $<1.07 \mathrm{e}-01$ & $1.35 e+04$ & $1.34 e+04$ & $1.35 e+04$ & 0.74 & 114.6 & 417.3 & $n / a$ \\
\hline S96T000557 & w & $\begin{array}{l}\text { Nitrate by IC-Dionex } \\
4000 \mathrm{i} / 4500\end{array}$ & $\mu \mathrm{g} / \mathrm{g}$ & 97.72 & $<1.40 \mathrm{e}-01$ & $1.27 e+03$ & $1.25 e+03$ & $1.26 e+03$ & 1.59 & 103.3 & 545.4 & $n / a$ \\
\hline 596T000557 & $w$ & $\begin{array}{l}\text { Phosphate-IC-Dionex } \\
4000 \mathrm{i} / 4500\end{array}$ & $\mu g / g$ & 100.2 & $<1.19 \mathrm{e}-01$ & $9.29 e+02$ & 985.0 & 957.0 & 5.85 & 109.7 & 463.7 & $n / a$ \\
\hline $596 \mathrm{T000557}$ & $w$ & $\begin{array}{l}\text { Sulfate by IC-Dionex } \\
4000 \mathrm{i} / 4500\end{array}$ & $\mu \mathrm{g} / \mathrm{g}$ & 97.94 & $<1.36 e-01$ & $4.12 e+03$ & $4.11 e+03$ & $4.11 \mathrm{e}+03$ & 0.24 & 105.1 & 529.8 & $n / a$ \\
\hline S96T000557 & w & Oxalate by IC-Dionex $4000 \mathrm{i}$ & $\mu \mathrm{g} / \mathrm{g}$ & 99.07 & $<1.05 \mathrm{e}-01$ & $7.80 e+04$ & $7.70 e+04$ & $7.75 e+04$ & 1.29 & 110.4 & 409.3 & $n / a$ \\
\hline \multicolumn{13}{|c|}{ Interstitial Liquid: Interstitial Liquid } \\
\hline S96T000545 & & $\begin{array}{l}\text { DSC Exotherm Dry } \\
\text { Calculated }\end{array}$ & Joules/g Dry & $n / a$ & $\mathbf{n} / \mathbf{a}$ & $0.00 e+00$ & $0.00 e+00$ & $0.00 e+\infty$ & 0.00 & $n / a$ & $\mathrm{n} / \mathbf{a}$ & $\overline{n / a}$ \\
\hline S96T000545 & & $\begin{array}{l}\text { DSC Exotherm on Perkin } \\
\text { Elmer }\end{array}$ & Joules/g & 95.82 & $n / a$ & $0.00 \mathrm{e}+00$ & $0.00 e+00$ & $0.00 e+00$ & 0.00 & $n / a$ & $n / a$ & $n / a$ \\
\hline S96T000545 & & $\begin{array}{l}\text { \% Waler by TGA on Perkin } \\
\text { Elmer }\end{array}$ & $\%$ & 102.0 & $n / \mathbf{a}$ & 34.27 & 36.53 & 35.40 & 6.38 & $n / a$ & $n / a$ & $n / a$ \\
\hline S96T000545 & & $\begin{array}{l}\text { TOC by Persulfatel } \\
\text { Coulometry }\end{array}$ & $\mu \mathrm{g} / \mathrm{mL}$ & 96.00 & 5.000 & $2.42 e+03$ & $2.43 e+03$ & $2.42 e+03$ & 0.41 & $n / a$ & 40.00 & $\sqrt{n / a}$ \\
\hline \$96T000545 & & Cobalt -60 by GEA & $\mu \mathrm{Ci} / \mathrm{mL}$ & 96.11 & $<6.53 \mathrm{e}-04$ & $<7.50 \mathrm{e}-03$ & $1.08 \mathrm{e}-02$ & $n / a$ & $n / a$ & $n / a$ & $8.000-03$ & $n / a$ \\
\hline S96T000545 & & Cesium- 137 by GEA & $\mu \mathrm{Ci} / \mathrm{mL}$ & 95.94 & $<4.940-04$ & 76.50 & 100.0 & 88.25 & 26.6 & $n / a$ & $n / a$ & 0.290 \\
\hline
\end{tabular}


Table A.2-1: Interim Results for Tank C-106 Grab Samples.

C-106 GRAB

Potential Organic Layer: Potential Organic Layer

\begin{tabular}{|c|c|c|c|c|c|c|c|c|c|c|c|c|}
\hline Sample \# R & $A \#$ & Analyte & Unit & \begin{tabular}{|l|} 
Standard \\
$\%$
\end{tabular} & Blank & Result & Duplicate & Average & $\begin{array}{l}\text { RPD } \\
\%\end{array}$ & $\begin{array}{l}\text { Spk Rec } \\
\%\end{array}$ & Det Limit & $\begin{array}{l}\text { Count Err } \\
\text { \% }\end{array}$ \\
\hline S96T001548 & & DSC Exotherm using Mettler & Joules/g & 112.5 & $\pi / a$ & $0.00 e+\infty$ & $0.00 e+\infty$ & $0.00 e+\infty$ & 0.00 & $n / a$ & $n / a$ & $\mathbf{n} / \mathbf{a}$ \\
\hline S96T001548 & & $\begin{array}{l}\text { DSC Exotherm Dry } \\
\text { Calculated }\end{array}$ & Joules/g Dry & $n / a$ & $n / a$ & $0.00 e+00$ & $0.00 c+\infty$ & $0.00 e+00$ & 0.00 & $n / a$ & $n / \mathbf{a}$ & $\mathbf{n} / \mathbf{a}$ \\
\hline S96T001548 & & $\begin{array}{l}\text { \% Water by TGA using } \\
\text { Mettler }\end{array}$ & $\%$ & 103.9 & $\pi / a$ & 34.16 & 35.78 & 34.97 & 4.63 & $n / 2$ & $n / a$ & $n / \mathbf{a}$ \\
\hline
\end{tabular}

RISER:1

SEGMENT A: 6C-96-8

SEGMENT PORTION: Compatibility Study Mixture

\begin{tabular}{|c|c|c|c|c|c|c|c|c|c|c|c|c|}
\hline Sample \# R & A * & Analyte & Unit & \begin{tabular}{|l|} 
Standard \\
$\%$
\end{tabular} & Blank & Result & Duplicate & Average & $\begin{array}{l}\text { RPD } \\
\%\end{array}$ & $\begin{array}{l}\text { Spk Rec } \\
\%\end{array}$ & Det Limit & $\begin{array}{l}\text { Count Enr } \\
x_{0}\end{array}$ \\
\hline S96T002765 & & pH Direct & $\mathrm{pH}$ & $n / a$ & $n / \mathbf{a}$ & 11.16 & n/a & $n / a$ & $n / a$ & $n / a$ & $1.00 \mathrm{e}-02$ & $\mathbf{n} / \mathbf{a}$ \\
\hline S96T002765 & & Specific Gravity & Sp.G. & 101.2 & $n / a$ & $9.80 \mathrm{e}-01$ & $9.77 e-01$ & $9.78 e-01$ & 0.31 & $n / \mathbf{a}$ & $1.00 \mathrm{e}-02$ & $\mathbf{n} / \mathbf{a}$ \\
\hline S96T002766 & & $\begin{array}{l}\text { DSC Exotherm on Perkin } \\
\text { Elmer }\end{array}$ & Joules/g & 100.6 & $n / \mathbf{a}$ & $0.00 e+\infty$ & $0.00 e+\infty$ & $0.00 e+\infty$ & 0.00 & $n / a$ & $n / \mathbf{a}$ & $n / a$ \\
\hline S96T002766 & & pH Direct & $\mathrm{pH}$ & $n / a$ & $\mathbf{n} / \mathbf{a}$ & 11.22 & $n / a$ & $\mathbf{n} / \mathbf{a}$ & $\mathbf{n} / \mathbf{a}$ & $\mathbf{n} / \mathbf{a}$ & $1.00 \mathrm{e}-02$ & $n / \mathbf{a}$ \\
\hline S96T002766 & & $\begin{array}{l}\text { \% Water by TGA on Perkin } \\
\text { Elmer }\end{array}$ & $\%$ & 97.87 & $n / a$ & 96.24 & 96.16 & 96.20 & 0.08 & $n / a$ & $\mathbf{n} / \mathbf{a}$ & $\mathbf{n} / \mathbf{a}$ \\
\hline S96T002769 & & Bulk Density of Samplc & $\mathrm{g} / \mathrm{mL}$ & $n / a$ & $\mathbf{n} / \mathbf{a}$ & & $\mathrm{n} / \mathbf{a}$ & $\mathbf{n} / \mathbf{a}$ & $n / a$ & $\mathbf{n} / \mathbf{a}$ & $5.000-01$ & $n / \mathfrak{a}$ \\
\hline S96T002769 & & $\begin{array}{l}\text { \%. Water by TGA using } \\
\text { Mettler }\end{array}$ & $\%$ & 99.54 & $n / a$ & 73.78 & 76.28 & 75.03 & 3.33 & $n / \mathbf{a}$ & $\mathrm{n} / \mathbf{a}$ & $n / 2$ \\
\hline S96T002770 & & DSC Exotherm using Mettler & Joules/g & 111.8 & $\mathbf{n} / \mathbf{a}$ & $0.00 x+00$ & $0.00 c+\infty$ & $0.00 e+\infty$ & 0.00 & $\mathbf{n} / \mathbf{a}$ & $n / a$ & $n / \mathbf{a}$ \\
\hline S96T002770 & & pH Direct & $\mathrm{pH}$ & $\mathbf{n} / \mathbf{a}$ & $n / a$ & 11.71 & 11.69 & 11.70 & 0.17 & $n / a$ & $1.00 \mathrm{e}-02$ & $n / a$ \\
\hline S96T002770 & & $\begin{array}{l}\text { \% Water by TGA using } \\
\text { Mettler }\end{array}$ & \% & 99.54 & $\mathbf{n} / \mathbf{a}$ & 96.86 & 97.03 & 96.94 & 0.18 & $\mathrm{n} / \mathrm{a}$ & $\mathrm{n} / \mathbf{a}$ & $n / a$ \\
\hline
\end{tabular}


Table A.2-1: Interim Results for Tank C-106 Grab Samples. C-106 GRAB

\begin{tabular}{|c|c|c|c|c|c|c|c|c|c|c|c|c|}
\hline \multicolumn{13}{|c|}{ SEGMENT PORTION: Compatibility Study Mixture (Continued) } \\
\hline Sample \# R & A \# & Analyte & Unit & $\begin{array}{l}\text { Standard } \\
\%\end{array}$ & Blank & Result & Duplicate & Average & $\begin{array}{l}\text { RPD } \\
x_{0}\end{array}$ & $\begin{array}{l}\text { Spk Rec } \\
\%\end{array}$ & Det Limit & $\begin{array}{l}\text { Count Err } \\
\%\end{array}$ \\
\hline S96T002772 & & Bulk Density of Sample & $\mathrm{g} / \mathrm{mL}$ & $\mathrm{n} / \mathrm{a}$ & $n / a$ & & $n / a$ & $n / a$ & $n / a$ & $\mathbf{n} / \mathbf{a}$ & $5.000-01$ & $\mathrm{n} / \mathrm{a}$ \\
\hline S96T002772 & & $\begin{array}{l}\% \text { Water by TGA using } \\
\text { Mettler }\end{array}$ & $\%$ & 99.54 & $n / a$ & 79.49 & 78.63 & 79.06 & 1.09 & $n / \mathbf{n}$ & $n / a$ & $\pi / \mathbf{a}$ \\
\hline \multicolumn{13}{|c|}{ Decanted Supernate (Liquid Grab Sludge): Decanted Supernate (Liquid Grab Sludge) } \\
\hline s96T002768 & & Specific Gravity & Sp.G. & 101.2 & $n / \mathbf{a}$ & 1.005 & $9.97 \mathrm{c}-01$ & 1.001 & 0.80 & $\pi / \mathbf{a}$ & $1.00=-02$ & $n / a$ \\
\hline$\$ 96 \mathrm{T002771}$ & & pH Direct & $\mathrm{pH}$ & $n / a$ & $\mathbf{n} / \mathbf{a}$ & 11.81 & 11.79 & 11.80 & 0.17 & $\mathbf{n} / \mathbf{a}$ & $1.00=-02$ & $n / a$ \\
\hline$\$ 96 T 002771$ & $\cdot$ & Specific Gravity & Sp.G. & 97.43 & $n / \mathfrak{a}$ & 1.002 & $9.91 \mathrm{e}-01$ & $9.96 \mathrm{e}-01$ & 1.10 & $\mathbf{n} / \mathbf{a}$ & $1.000-02$ & $n / a$ \\
\hline \multicolumn{13}{|c|}{ Potential Organic Layer: Potential Organic Layer } \\
\hline$\$ 96 \mathrm{~T} 003134$ & & 2-Butoxyethanol & $\mu \mathrm{g} / \mathrm{L}$ & $n / a$ & $n / a$ & SEETICS & NA & $n / a$ & $n / a$ & $n / \mathbf{a}$ & $n / \mathbf{a}$ & $\mathrm{n} / \mathrm{a}$ \\
\hline$\$ 96 T 003134$ & & Nonane (C9) & $\mu \mathrm{g} / \mathrm{mL}$ & $n / a$ & $n / a$ & $\mathrm{U} 0.00 e+00$ & $n / \mathbf{a}$ & $n / a$ & $n / a$ & $\mathrm{n} / \mathbf{a}$ & 50.00 & $n / a$ \\
\hline S96T003134 & & Decane (C10) & $\mu \mathrm{g} / \mathrm{mL}$ & $n / a$ & $n / a$ & $\mathrm{U} 0.00 e+00$ & $n / a$ & $n / a$ & $n / a$ & $\mathbf{n} / \mathbf{a}$ & 50.00 & $n / 2$ \\
\hline \$96T003134 & & Undecane (C11) & $\mu \mathrm{g} / \mathrm{mL}$ & $n / a$ & $n / a$ & $\mathrm{~J} 1.590$ & $n / 2$ & $n / a$ & $n / 2$ & $n / \mathbf{a}$ & 50.00 & $n / a$ \\
\hline S96T003134 & & Dodocane $(\mathrm{Cl} 2)$ & $\mu \mathrm{g} / \mathrm{mL}$ & $n / a$ & $n / a$ & $\$ 10.10$ & $n / \mathbf{a}$ & $n / a$ & $n / a$ & $\mathbf{n} / \mathbf{a}$ & 50.00 & $n / a$ \\
\hline S96T003134 & & Tridecane (C13) & $\mu \mathrm{g} / \mathrm{mL}$ & $n / 2$ & $n / a$ & $\mathrm{~J} 45.60$ & $n / a$ & $n / \mathbf{a}$ & $n / a$ & $n / a$ & 50.00 & $n / a$ \\
\hline S96T003134 & & Tetradecane (C14) & $\mu \mathrm{g} / \mathrm{mL}$ & $n / a$ & $n / a$ & $J 27.60$ & $n / \mathbf{a}$ & $n / a$ & $n / a$ & $n / a$ & 50.00 & $n / a$ \\
\hline $596 T 003134$ & & Pentadecane (C15) & $\mu \mathrm{g} / \mathrm{mL}$ & $n / a$ & $n / a$ & $\mathrm{~J} 2.370$ & $n / a$ & $n / a$ & $n / a$ & $n / a$ & 50.00 & $n / a$ \\
\hline S96T003134 & & Tri-n-butylphosphate & $\mu \mathrm{g} / \mathrm{mL}$ & $n / s$ & $n / a$ & $\mathrm{~J} 31.90$ & $n / 2$ & $n / a$ & $n / 2$ & $n / 2$ & 50.00 & $n / a$ \\
\hline S96T003134 & & Hexadecane (C16) Surr & $\mu \mathrm{g} / \mathrm{mL}$ & $n / a$ & $n / a$ & 83.50 & $\mathbf{n} / \mathbf{a}$ & $n / a$ & $n / a$ & $n / a$ & 50.00 & $n / a$ \\
\hline
\end{tabular}


Table A.2-1: Interim Results for Tank C-106 Grab Samples.

C-106 GRAB

\begin{tabular}{|c|c|c|c|c|c|c|c|c|c|c|c|c|}
\hline \multicolumn{13}{|c|}{ Sludge (from Liquid Grab Sample): Sludge (from Liquid Grab Sample) } \\
\hline Sample \# R & $A$ * & Analyte & Unit & $\begin{array}{l}\text { Standard } \\
\%\end{array}$ & Blank & Result & Duplicate & Average & $\begin{array}{l}\text { RPD } \\
\%\end{array}$ & $\begin{array}{l}\text { Spk Rec } \\
\%\end{array}$ & Det Limit & $\begin{array}{l}\text { Count Err } \\
\%\end{array}$ \\
\hline$\$ 96 \mathrm{T000854}$ & & $\begin{array}{l}\text { TOC by Persulfatel } \\
\text { Coulometry }\end{array}$ & $\mu \mathrm{g} / \mathrm{g}$ & 95.36 & 8.300 & $1.34 e+04$ & $9.32 \mathrm{e}+03$ & $1.14 e+04$ & 35.9 & $\mathrm{n} / \mathrm{a}$ & 40.00 & $\mathrm{n} / \mathrm{a}$ \\
\hline S96T002021 & & DSC Exotherm using Mettler & Joules/g & 97.72 & $\mathrm{n} / \mathrm{a}$ & 33.50 & 100.6 & 67.05 & 100 & $n / a$ & $n / a$ & $n / a$ \\
\hline S96T002021 & & $\begin{array}{l}\text { DSC Exotherm Dry } \\
\text { Calculated }\end{array}$ & Joules/g Dry & $n / a$ & $n / a$ & 71.10 & 213.5 & 142.3 & 100 & $n / a$ & $n / a$ & $n / a$ \\
\hline S96T002021 & & $\begin{array}{l}\text { \% Water by TGA using } \\
\text { Mettler }\end{array}$ & $\%$ & 99.93 & $n / a$ & 59.60 & 46.16 & 52.88 & 25.4 & $n / a$ & $n / a$ & $\mathrm{n} / \mathbf{a}$ \\
\hline S96T002042 & & $\begin{array}{l}\text { DSC Exotherm Dry } \\
\text { Calculated }\end{array}$ & Joules/g Dry & $\mathrm{n} / \mathrm{a}$ & $n / a$ & $0.00 \mathrm{e}+\infty 0$ & $0.00 \mathrm{e}+\infty 0$ & $0.00 \mathrm{e}+00$ & 0.00 & $\mathrm{n} / \mathrm{a}$ & $\mathbf{n} / \mathbf{a}$ & $n / a$ \\
\hline S96T002042 & & $\begin{array}{l}\text { DSC Exotherm on Perkin } \\
\text { Elmer }\end{array}$ & Joules/g & 92.02 & $n / a$ & $0.00 e+\infty$ & $0.00 \mathrm{e}+00$ & $0.00 c+00$ & 0.00 & $n / a$ & $\mathbf{n} / \mathbf{a}$ & $n / a$ \\
\hline$\$ 96 T 002042$ & & $\begin{array}{l}\% \text { Water by TGA using } \\
\text { Mettler }\end{array}$ & $\%$ & 99.16 & $n / a$ & 60.45 & 60.55 & 60.50 & 0.17 & $n / a$ & $\mathbf{n} / \mathbf{a}$ & $n / a$ \\
\hline$\$ 96 T 0020421$ & & $\begin{array}{l}\text { \% Water by TGA using } \\
\text { Mettler }\end{array}$ & $\%$ & 99.83 & $n / a$ & 56.10 & 54.50 & 55.30 & 2.89 & $n / a$ & $n / a$ & $n / a$ \\
\hline \multicolumn{13}{|l|}{ RISER: 7} \\
\hline \multicolumn{13}{|c|}{ SEGMENT \#: 2 AY-96-6 } \\
\hline \multicolumn{13}{|c|}{ SEGMENT PORTION: Supernate } \\
\hline S96T002833 & & pH Direct & $\mathrm{pH}$ & $\mathrm{n} / \mathbf{a}$ & $n / a$ & 12.52 & $\mathrm{n} / \mathrm{a}$ & $\mathrm{n} / \mathrm{a}$ & $n / \mathbf{a}$ & $n / a$ & $1.00 e-02$ & $\mathrm{n} / \mathbf{a}$ \\
\hline S96TO02833 & & Specific Gravity & Sp.G. & 101.2 & ora & $9.76 e-01$ & $9.87 e-01$ & $9.820-0 i$ & 1.12 & $\mathbf{n} / \mathbf{a}$ & $1.00-02$ & 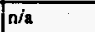 \\
\hline
\end{tabular}


Table A.2-1: Interim Results for Tank C-106 Grab Samples. C-106 GRAB

SEGMENT \#: 6C-96-11

SEGMENT PORTION: Centrifuged Solids (Grab Sample)

\begin{tabular}{|c|c|c|c|c|c|c|c|c|c|c|c|}
\hline S96T001674 & Bulk Density of Sample & $\mathrm{g} / \mathrm{mL}$ & $n / a$ & $\mathbf{n} / \mathbf{a}$ & 1.450 & $\mathbf{n} / \mathbf{a}$ & $\mathrm{n} / \mathrm{a}$ & $\mathrm{n} / \mathrm{a}$ & $\ln / \mathbf{a}$ & $5.00 \mathrm{e}-01$ & $n / a$ \\
\hline S96T001674 & DSC Exotherm using Mettler & Joules/g & 97.72 & $n / a$ & 19.70 & 109.6 & 64.65 & 139 & $\mathrm{n} / \mathrm{a}$ & $n / \mathbf{a}$ & $n / \mathbf{a}$ \\
\hline S96T001674 & $\begin{array}{l}\text { DSC Exotherm Dry } \\
\text { Calculated }\end{array}$ & Joules/g Dry & $n / a$ & $\mathrm{n} / \mathrm{a}$ & 21.66 & 120.5 & 71.08 & 139 & $\mathbf{n} / \mathbf{a}$ & $n / \mathbf{a}$ & $\mathrm{n} / \mathrm{a}$ \\
\hline S96T001674 & $\begin{array}{l}\text { \% Water by TGA using } \\
\text { Mettler }\end{array}$ & क & 99.93 & $\mathrm{n} / \mathrm{a}$ & 9.630 & 8.430 & 9.030 & 13.3 & $n / a$ & $n / \mathbf{a}$ & $\mathrm{n} / \mathbf{a}$ \\
\hline S96T001674 & Volume $\%$ Solids & $\%$ & n/a & $\mathrm{n} / \mathrm{a}$ & 59.50 & $\mathbf{n} / \mathbf{a}$ & $n / a$ & $\mathbf{n} / \mathbf{a}$ & $n / \mathbf{a}$ & $\mathrm{n} / \mathrm{a}$ & $\mathrm{n} / \mathbf{a}$ \\
\hline S96T001674 & \% Waler by Gravimetric & $\%$ & 100.8 & $\mathrm{n} / \mathbf{a}$ & 12.40 & 10.90 & 11.65 & 12.9 & $\mathbf{n} / \mathbf{a}$ & $1.000-02$ & $n / \mathbf{a}$ \\
\hline
\end{tabular}

Control Sample: Control Sample

\begin{tabular}{|c|c|c|c|c|c|c|c|c|c|c|c|c|}
\hline S96T001676 & & DSC Exotherm using Metler & Joules/g & 112.1 & $n / a$ & $1.46 e+02$ & 137.2 & 141.6 & 6.21 & $\mathbf{n} / \mathbf{n}$ & $\pi / a$ & $\mathrm{n} / \mathbf{a}$ \\
\hline S96T001676 & & $\begin{array}{l}\text { DSC Exotherm Dry } \\
\text { Calculated }\end{array}$ & Joules/g Dry & $n / a$ & $n / \mathbf{a}$ & $2.42 e+02$ & 227.8 & 235.1 & 6.21 & $\mathbf{n} / \mathbf{a}$ & $\mathbf{n} / \mathbf{a}$ & $n / a$ \\
\hline S96T001676 & & $\begin{array}{l}\text { \% Water by TGA using } \\
\text { Mettler }\end{array}$ & $\%$ & 102.3 & $n / 2$ & $\mathbf{4 0 . 0 5}$ & 39.47 & 39.76 & 1,46 & n/a & $n / \mathbf{a}$ & $\mathrm{n} / \mathbf{a}$ \\
\hline S96T001678 & $\mathbf{F}$ & Technetium-99 Liq. Scint. & $\mu \mathrm{Ci} / \mathrm{g}$ & 99.21 & $n / a$ & $1.93 \mathrm{e}-02$ & $2.75 e-02$ & $2.34 \mathrm{e}-02$ & 35.0 & $\mathbf{n} / \mathbf{a}$ & $1.80 \mathrm{c}-02$ & $6.25 \mathrm{E}+\infty$ \\
\hline S96T001678 & $\mathbf{F}$ & Strontium-89/90 High Level & $\mu \mathrm{Ci} / \mathrm{g}$ & 102.4 & $7.55 \mathrm{e}-01$ & $3.83 e+02$ & 381.0 & 382.0 & 0.52 & $\mathbf{n} / \mathbf{a}$ & $2.36 e-01$ & $7.89 \mathrm{E}-01$ \\
\hline S96T001678 & F & $\begin{array}{l}\text { Pu-239/240 by TRU-SPEC } \\
\text { Resin }\end{array}$ & $\mu \mathrm{Ci} / \mathrm{g}$ & 100.3 & $<1.71002$ & $7.75 \mathrm{e}-01$ & 7.65e-01 & $7.70=-01$ & 1.30 & $\mathbf{n} / \mathbf{a}$ & $4.900-02$ & $2.01 E+\infty$ \\
\hline S96T001678 & $\mathbf{F}$ & Cobalt- 60 by GEA & $\mu \mathrm{Ci} / \mathrm{g}$ & 99.96 & $<1.06 \mathrm{e}-03$ & $<7.17 \mathrm{e}-01$ & $<5.87 e-1$ & $n / a$ & $\mathrm{n} / \mathrm{a}$ & $\mathbf{n} / \mathbf{a}$ & $7.17 \mathrm{e}-01$ & $n / a$ \\
\hline S96T001678 & $\mathbf{F}$ & Cesium-137 by GEA & $\mu \mathrm{Ci} / \mathrm{g}$ & 100.6 & $<2.56 \mathrm{e}-03$ & $4.50 e+02$ & 408.0 & 429.1 & 9.79 & $\mathbf{a} / \mathbf{a}$ & $n / a$ & 1.55 \\
\hline S96T001678 & $\mathrm{F}$ & Am-241 by Extraction & $\mu \mathrm{Ci} / \mathrm{g}$ & 97.13 & $<1.310-02$ & $7.03 \mathrm{e}-01$ & $7.15 e-01$ & 7.09e-01 & 1.69 & $n / \mathbf{a}$ & $6.100-02$ & $2.64 \mathrm{E}+00$ \\
\hline S96T001678 & $\mathbf{F}$ & Aipha of Digested Solid & $\mu \mathrm{Ci} / \mathrm{g}$ & 102.3 & $<4.10 \mathrm{e}-02$ & 1.500 & 1.620 & 1.560 & 7.69 & 91.09 & $6.10 e-02$ & $9.65 \mathrm{E}+00$ \\
\hline S96T001675 & & Specific Gravity & Sp.G. & 102.1 & $n / \mathbf{x}$ & 1.153 & 1.138 & 1.145 & 1.31 & $n / a$ & $1.000-03$ & $n / \mathbf{a}$ \\
\hline S96T001675 & & \% Water by Gravimetric & $\%$ & 98.82 & $n / 2$ & 78.20 & 78.30 & 78.25 & 0.13 & $\mathbf{n} / \mathbf{a}$ & $1.000-02$ & $n / a$ \\
\hline
\end{tabular}


Table A.2-1: Interim Results for Tank C-106 Grab Samples.

C-106 GRAB

Decanted Supemate (Liquid Grab Sludge): Decanted Supernate (Liquid Grab Sludge) (Continued)

\begin{tabular}{|c|c|c|c|c|c|c|c|c|c|c|c|c|}
\hline Sample \# $\mathbf{R}$ & A * & Analyte & Unit & $\begin{array}{c}\text { Standard } \\
\%\end{array}$ & Blank & Result & Duplicate & Average & $\begin{array}{c}\text { RPD } \\
\%\end{array}$ & $\underset{\%}{\text { Spk Rec }}$ & Det Limit & $\begin{array}{c}\text { Count Err } \\
\%\end{array}$ \\
\hline S96T002024 & & pH Direct & $\mathrm{pH}$ & $\mathbf{n} / \mathbf{a}$ & $n / a$ & 10.15 & $\mathbf{n} / \mathbf{a}$ & $n / a$ & $n / a$ & $\mathbf{n} / \mathbf{a}$ & $1.00=02$ & $n / \mathbf{a}$ \\
\hline S96T002024 & & Specific Gravity & Sp.G. & 97.74 & $\pi / a$ & 1.195 & 1.195 & 1.195 & 0.00 & $\mathbf{n} / \mathbf{a}$ & $1.00 \mathrm{e}-03$ & $\mathrm{n} / \mathrm{a}$ \\
\hline S96T002024 & & $\begin{array}{l}\text { Fluoride-IC-Dionex } \\
4000 \mathrm{j} / 4500\end{array}$ & $\mu \mathrm{g} / \mathrm{mL}$ & 98.98 & $<1.30 \mathrm{e}-02$ & $2.01 e+02$ & 209.0 & 205.1 & 3.90 & 127.5 & 14.44 & $n / \mathbf{a}$ \\
\hline$\$ 96 \mathrm{T002024}$ & & $\begin{array}{l}\text { Chloride-IC-Dionex } \\
4000 \mathrm{i} / 4500\end{array}$ & $\mu \mathrm{g} / \mathrm{mL}$ & 99.75 & $<1.70 e-02$ & $2.58 e+02$ & 266.0 & 261.9 & 3.05 & 97.85 & 18.89 & $n / a$ \\
\hline S96T002024 & & Nitrite-IC-Dionex $4000 \mathrm{i} / 4500$ & $\mu \mathrm{g} / \mathrm{mL}$ & 103.5 & $<1.07001$ & $2.59 e+04$ & $2.79 e+04$ & $2.69 e+04$ & 7.43 & 134.9 & 118.9 & $n / a$ \\
\hline S96T002024 & & Nitrate-IC-Dionex $4000 \mathrm{i} / 4500$ & $\mu \mathrm{g} / \mathrm{mL}$ & 103.1 & $<1.40 \mathrm{e}-0 \mathrm{I}$ & $9.81 e+02$ & $1.01 e+03$ & 995.5 & 2.91 & 97.23 & 155.5 & $n / a$ \\
\hline S96T002024 & & $\begin{array}{l}\text { Phosphate-IC-Dionex } \\
4000 \mathrm{i} / 4500\end{array}$ & $\mu \mathrm{g} / \mathrm{mL}$ & 103.5 & $<1.19 e_{0.01}$ & $4.42 e+02$ & 480.0 & 460.9 & 8.24 & 101.3 & 132.1 & $n / a$ \\
\hline 596T002024 & & $\begin{array}{l}\text { Sulfate by IC-Dionex } \\
4000 \mathrm{i} / 4500\end{array}$ & $\mu \mathrm{g} / \mathrm{mL}$ & 101.6 & $<1.36 \mathrm{e}-01$ & $6.69 e+03$ & $7.20 e+03$ & $6.94 e+03$ & 7.34 & 112.2 & 151.0 & $n / a$ \\
\hline $596 \mathrm{~T} 002024$ & & Oxalate by IC-Dionex $4000 \mathrm{i}$ & $\mu \mathrm{g} / \mathrm{mL}$ & 103.2 & $<1.05 \mathrm{e}-01$ & $3.18 e+03$ & $3.45 \mathrm{e}+03$ & $3.31 e+03$ & 8.14 & 106.3 & 116.7 & $n / a$ \\
\hline S96T002024 & & Cobalt- 60 by GEA & $\mu \mathrm{Ci} / \mathrm{mL}$ & 93.30 & $<8.67 e-04$ & $<4.63 \mathrm{e}-03$ & $<4.49 \mathrm{e}-3$ & $n / a$ & $n / a$ & $\mathbf{n} / \mathbf{a}$ & $5.000-03$ & $n / a$ \\
\hline S96T002024 & & Cesium- 137 by GEA & $\mu \mathrm{Ci} / \mathrm{mL}$ & 90.88 & $<2.68 \mathrm{e}-03$ & $1.28 \mathrm{e}+02$ & 127.0 & 127.5 & 0.78 & $\mathbf{n} / \mathbf{a}$ & $n / a$ & 0.140 \\
\hline \multicolumn{13}{|c|}{ Filtered Centrifuged Solids: Filhered Centrifuged Solids } \\
\hline Sample \# $\mathbf{R}$ & A H & Aralyte & Unit & $\begin{array}{c}\text { Standard } \\
\%\end{array}$ & Blank & Result & Duplicate & Average & $\begin{array}{c}\text { RPD } \\
\%\end{array}$ & $\underset{\%}{\text { Spk Rec }}$ & Det Limit & $\begin{array}{c}\text { Count Err } \\
*\end{array}$ \\
\hline S96T001685 & & $\begin{array}{l}\text { DSC Exotherm Dry } \\
\text { Calculated }\end{array}$ & Joules/g Dry & $n / a$ & $n / a$ & $0.00 e+00$ & $0.00 e+00$ & $0.00 e+00$ & 0.00 & $n / a$ & $n / a$ & $n / a$ \\
\hline S96T001685 & & $\begin{array}{l}\text { DSC Exotherm on Perkin } \\
\text { Elmer }\end{array}$ & Joules/g & 100.3 & $n / a$ & $0.00 c+00$ & $0.00 c+00$ & $0.00 c+00$ & 0.00 & $n / \mathbf{a}$ & $n / a$ & $n / a$ \\
\hline S96T001685 & & $\begin{array}{l}\text { \% Water by TGA on Perkin } \\
\text { Elmer }\end{array}$ & $\%$ & 99.39 & $n / \mathbf{a}$ & 32.54 & 31.29 & 31.91 & 3.92 & $\pi / a$ & $\mathrm{n} / \mathbf{a}$ & $\mathrm{n} / \mathrm{a}$ \\
\hline S96T001686 & & TIC by Acid/Coulometry & $\mu \mathrm{g} / \mathrm{g}$ & 93.68 & $3.000-01$ & $2.32 e+04$ & $2.28 c+04$ & $2.30 c+04$ & 1.74 & $n / 2$ & 5.000 & $\mathrm{n} / \mathrm{a}$ \\
\hline
\end{tabular}


Table A.2-1: Interim Results for Tank C-106 Grab Samples.

C-106 GRAB

Filtered Centrifuged Solids: Filtered Centrifuged Solids (Continued)

\begin{tabular}{|c|c|c|c|c|c|c|c|c|c|c|c|c|}
\hline Sample \# & A \# & Analyte & Unit & $\begin{array}{c}\text { Standard } \\
\%\end{array}$ & Blank & Result & \begin{tabular}{|l|} 
Duplicate \\
\end{tabular} & Average & $\begin{array}{c}\text { RPD } \\
\%\end{array}$ & \begin{tabular}{|c|} 
Spk Rec \\
$\%$
\end{tabular} & Det Limit & $\begin{array}{c}\text { Count ET } \\
\%\end{array}$ \\
\hline S96T001686 & & $\begin{array}{l}\text { TOC by Persulfatel } \\
\text { Coulometry }\end{array}$ & $\mu \mathrm{g} / \mathrm{g}$ & 94.03 & 3.000 & $2.00 x+04$ & $1.73 e+04$ & $1.86 e+04$ & 14.5 & $n / \mathbf{a}$ & 40.00 & $n / a$ \\
\hline S96T001687 & & \% Water by Gravimetric & $\%$ & 98.99 & $n / \mathbf{a}$ & 34.10 & 34.10 & 34.10 & 0.00 & $n / \mathbf{n}$ & $1.00 \mathrm{e}-02$ & $\pi / 2$ \\
\hline S96T001688 & & $\mathrm{pH}$ on SST Samples & pH & $n / \mathbf{a}$ & $n / a$ & 10.42 & $\mathbf{n} / \mathbf{a}$ & $n / a$ & $\pi / a$ & $n / a$ & $1.000-02$ & $n / \mathbf{n}$ \\
\hline S96T001689 & $F$ & Technetium-99 Liq. Scint. & $\mu \mathrm{Ci} / \mathrm{g}$ & 99.21 & $n / a$ & $2.97 e-02$ & $5.04 \mathrm{e}-01$ & $2.67 e-01$ & 178 & $n / \mathbf{a}$ & $2.900-02$ & $6.23 \mathrm{E}+00$ \\
\hline S96T001689 & $\mathbf{F}$ & Strontium-89/90 High Level & $\mu \mathrm{Ci} / \mathrm{g}$ & 102.4 & $7.55 \mathrm{e}-01$ & $4.87 e+02$ & 523.0 & 505.0 & 7.13 & $n / \mathbf{a}$ & $4.36=01$ & $9.54 \mathrm{E}-01$ \\
\hline S96T001689 & $F$ & $\begin{array}{l}\text { Pu-239/240 by TRU-SPEC } \\
\text { Resin }\end{array}$ & $\mu \mathrm{Ci} / \mathrm{g}$ & 100.3 & $<1.71 \mathrm{e}-02$ & $9.010-01$ & $9.26 \mathrm{e}-01$ & $9.13 e-01$ & 2.74 & $n / \mathbf{a}$ & $7.40=02$ & $2.18 \mathrm{E}+\infty$ \\
\hline S96T001689 & $\mathbf{F}$ & Cobalt- 60 by GEA & $\mu \mathrm{Ci} / \mathrm{g}$ & 99.72 & $<2.20 \mathrm{e}-02$ & $<3.03 e-01$ & $<4.13 \mathrm{e}-1$ & $n / a$ & $n / \mathbf{a}$ & $n / \mathbf{a}$ & $3.03 \mathrm{e}-01$ & $n / a$ \\
\hline S96T001689 & $\mathbf{F}$ & Cesium-137 by GEA & $\mu \mathrm{Ci} / \mathrm{g}$ & 100.9 & $<5.54 \mathrm{e}-01$ & $4.83 e+02$ & 509.0 & 495.9 & 5.24 & $n / a$ & $n / a$ & 0.990 \\
\hline S96T001689 & $\mathbf{F}$ & Am-241 by Extraction & $\mu \mathrm{Ci} / \mathrm{g}$ & 97.13 & $<1.31 \mathrm{e}-02$ & 1.030 & $9.80 \mathrm{e}-01$ & 1.005 & 4.98 & $n / a$ & $9.80 \mathrm{e}-02$ & $2.85 \mathrm{E}+00$ \\
\hline S96T001689 & $F$ & Alpha of Digested Solid & $\mu \mathrm{Ci} / \mathrm{g}$ & 102.3 & $<4.10 \mathrm{e}-02$ & 1.680 & 1.840 & 1.760 & 9.09 & 93.31 & $1.13 \mathrm{e}-01$ & $1.23 \mathrm{E}+01$ \\
\hline S96T001690 & $\bar{A}$ & Silver-ICP-Acid Digest & $\mu \mathrm{g} / \mathrm{g}$ & 90.20 & $<1.00=02$ & $1.96 e+03$ & $1.25 \mathrm{e}+03$ & $1.60 e+03$ & 44.2 & 139.0 & 3.830 & $n / \mathbf{a}$ \\
\hline S96T001690 & $A$ & Aluminum-ICP-Acid Digest & $\mu \mathrm{g} / \mathrm{g}$ & 91.40 & $1.09 c-01$ & $3.81 \mathrm{e}+04$ & $3.77 c+04$ & $3.79 c+04$ & 1.06 & 130.2 & 19.10 & $n / a$ \\
\hline S96T001690 & $\mathbf{A}$ & Arsenic-ICP-Acid Digest & $\mu \mathrm{g} / \mathrm{g}$ & 93.80 & $<1.00 \mathrm{e}-01$ & $<38.30$ & $<3.93 \mathrm{el}$ & n/a & $\mathbf{n} / \mathbf{a}$ & 90.50 & 38.30 & $n / a$ \\
\hline S96T001690 & $\mathbf{A}$ & Boron-ICP-Acid Digest & $\mu \mathrm{g} / \mathrm{g}$ & 97.60 & $6.50 \mathrm{c}-01$ & 25.80 & 30.70 & 28.25 & 17.3 & 90.36 & 19.10 & $\mathrm{n} / \mathbf{a}$ \\
\hline S96T001690 & A & Barium-ICP-Acid Digest & $\mu \mathrm{g} / \mathrm{g}$ & 94.00 & $<5.00 \mathrm{e}-02$ & $2.22 e+02$ & 219.0 & 220.5 & 1.36 & 90.42 & 19.10 & $\mathbf{n} / \mathbf{a}$ \\
\hline S96T001690 & A & Beryllium-ICP-Acid Digest & $\mu \mathrm{g} / \mathrm{g}$ & 102.6 & $<5.00 \mathrm{e}-03$ & $<1.910$ & $<1.97 \mathrm{e0}$ & $n / a$ & $n / \mathbf{n}$ & 97.50 & 1.910 & $n / a$ \\
\hline \$96T001690 & A & Bismuth-ICP-AcidDigest & $\mu \mathrm{g} / \mathrm{g}$ & 91.20 & $<1.000-01$ & $<38.30$ & $<3.93 \mathrm{el}$ & $n / a$ & $n / a$ & 91.10 & 38.30 & $\mathbf{n} / \mathbf{a}$ \\
\hline S96T001690 & $A$ & Calcium-ICP-AcidDigest & $\mu \mathrm{g} / \mathrm{g}$ & 91.60 & $1.28 \mathrm{e}-01$ & $2.65 e+03$ & $2.50 c+03$ & $2.58 c+\infty$ & 5.83 & 84.64 & 38.30 & $\mathbf{n} / \mathbf{a}$ \\
\hline S96T001690 & A & Cadmium-ICP-Acid Digest & $\mu \mathrm{g} / \mathrm{g}$ & 89.60 & $<5.000-03$ & 23.90 & 24.80 & 24.35 & $\mathbf{3 . 7 0}$ & 88.24 & 1.910 & $n / a$ \\
\hline S96T001690 & A & Cerium-ICP-Acid Digest & $\mu g / g$ & 97.00 & $<1.000-01$ & $1.41 e+02$ & 152.0 & 146.5 & 7.51 & 94.62 & 38.30 & $n / \mathbf{a}$ \\
\hline$\$ 96 \mathrm{~T} 001690$ & A & Cobalt-ICP-Acid Digest & $\mu \mathrm{g} / \mathrm{g}$ & 92.40 & $<2.000-02$ & $<7.660$ & 8.350 & $\mathrm{n} / \mathbf{a}$ & $\mathbf{n} / \mathbf{a}$ & 90.60 & 7.660 & $\mathbf{n} / \mathbf{a}$ \\
\hline
\end{tabular}


Table A.2-1: Interim Results for Tank C-106 Grab Samples.

C-106 GRAB

Filtered Centrifuged Solids: Filtered Centrifuged Solids (Continued)

\begin{tabular}{|c|c|c|c|c|c|c|c|c|c|c|c|c|}
\hline Sample \# $\mathbf{R}$ & A\# & Analyte & Unit & \begin{tabular}{|c|} 
Standard \\
$\%$
\end{tabular} & Blank & Result & Duplicate & Average & $\begin{array}{c}\text { RPD } \\
\%\end{array}$ & $\begin{array}{c}\text { Spk Rec } \\
\%\end{array}$ & Det Limit & $\begin{array}{c}\text { Count Err } \\
\%\end{array}$ \\
\hline S96T001690 & A & Chromium-ICP-Acid Digest & $\mu \mathrm{g} / \mathrm{g}$ & 91.00 & $<1.00 \mathrm{e}-02$ & $5.28 e+02$ & 538.0 & 533.0 & 1.88 & 90.42 & 3.830 & $n / \mathbf{a}$ \\
\hline $596 \mathrm{~T} 001690$ & A & Copper-ICP-Acid Digest & $\mu \mathrm{g} / \mathrm{g}$ & 92.00 & $1.10 \mathrm{e}-02$ & 95.60 & 94.20 & 94.90 & 1.48 & 89.50 & 3.830 & $n / \mathbf{a}$ \\
\hline S96T001690 & A & Iron-ICP-Acid Digest & $\mu \mathrm{g} / \mathrm{g}$ & 90.80 & $5.00 \mathrm{e}-02$ & $4.59 e+04$ & $5.74 e+04$ & $5.16 e+04$ & 22.3 & 81.64 & 19.10 & $\mathrm{n} / \mathrm{a}$ \\
\hline S96T001690 & $\mathbf{A}$ & Potassium-ICP-Acid Digest & $\mu \mathrm{g} / \mathrm{g}$ & 93.00 & $<5.00 \mathrm{e}-01$ & $5.53 e+02$ & 514.0 & 533.5 & 7.31 & 96.10 & 191.0 & $n / a$ \\
\hline$\$ 967001690$ & $A$ & Lanthanum-ICP-Acid Digest & $\mu \mathrm{g} / \mathrm{g}$ & 94.40 & $<5.00 e-02$ & 49.60 & 47.80 & 48.70 & 3.70 & 91.60 & 19.10 & $n / a$ \\
\hline S96T001690 & A & Lithium-ICP-Acid Digest & $\mu \mathrm{g} / \mathrm{g}$ & 95.20 & $<1.00 \mathrm{e}-02$ & $<3.830$ & $<3.93 e 0$ & $n / a$ & $n / a$ & 92.00 & 3.830 & $n / a$ \\
\hline S96T001690 & A & Magnesium-ICP-Acid Digest & $\mu \mathrm{g} / \mathrm{g}$ & 86.40 & $<1.00 e-01$ & $2.50 \mathrm{e}+02$ & 264.0 & 257.0 & 5.45 & 85.64 & 38.30 & $n / a$ \\
\hline S96T001690 & A & Manganese-ICP-Acid Digest & $\mu \mathrm{g} / \mathrm{g}$ & 90.80 & $<1.00 e-02$ & $3.21 \mathrm{e}+03$ & $3.27 e+03$ & $3.24 e+03$ & 1.85 & 102.1 & 3.830 & $n / a$ \\
\hline S96T001690 & A & $\begin{array}{l}\text { Molybdenum-ICP-Acid } \\
\text { Digest }\end{array}$ & $\mu \mathrm{g} / \mathrm{g}$ & 91.40 & $<5.00 \mathrm{e}-02$ & $<19.10$ & $<1.97 \mathrm{el}$ & $n / a$ & $\mathbf{n} / \mathbf{a}$ & 89.50 & 19.10 & $n / a$ \\
\hline S96T001690 & A & Sodium-ICP-Acid Digest & $\mu \mathrm{g} / \mathrm{g}$ & 103.6 & $8.77 e-01$ & $1.08 e+05$ & $1.08 e+05$ & $1.08 e+05$ & 0.00 & $n / \mathbf{a}$ & 38.30 & $n / a$ \\
\hline S96T001690 & A & Neodymium-ICP-Acid Digest & $\mu \mathrm{g} / \mathrm{g}$ & 93.80 & $<1.00 e-01$ & $1.28 e+02$ & 125.0 & 126.5 & 2.37 & 91.22 & 38.30 & $n / 9$ \\
\hline \multicolumn{13}{|c|}{ Filtered Centrifuged Solids: Filtered Centrifuged Solids } \\
\hline S96T001690 & A & Nickel-ICP-Acid Digest & $\mu \mathrm{g} / \mathrm{g}$ & 91.80 & $<2.00 \mathrm{e}-02$ & $5.15 e+02$ & 518.0 & 516.5 & 0.58 & 91.10 & 7.660 & $n / a$ \\
\hline S96T001690 & $A$ & Phosphorus-ICP-Acid Digest & $\mu \mathrm{g} / \mathrm{g}$ & 96.80 & $<2.00 \mathrm{e}-01$ & $1.76 e+03$ & $1.81 \mathrm{e}+03$ & $1.78 e+03$ & 2.80 & 110.1 & 76.60 & $n / \mathbf{a}$ \\
\hline S96T001690 & A & Lead-ICP-Acid Digest & $\mu g / g$ & 86.80 & $<1.00 e-01$ & $1.90 e+03$ & $1.95 e+03$ & $1.92 e+03$ & 2.60 & 89.66 & 38.30 & $n / a$ \\
\hline $596 \mathrm{~T} 001690$ & A & Sulfur-ICP-Acid Digest & $\mu \mathrm{g} / \mathrm{g}$ & 90.20 & $<1.00 k-01$ & $9.18 c+02$ & 938.0 & 928.0 & 2.16 & 93.06 & 38.30 & $n / \mathbf{a}$. \\
\hline S96T001690 & A & Antimony-ICP-Acid Digest & $\mu \mathrm{g} / \mathrm{g}$ & 93.40 & $<6.00 e-02$ & $<23.00$ & $<2.36 \mathrm{el}$ & $n / a$ & $n / a$ & 92.50 & 23.00 & $n / a$ \\
\hline S96T001690 & A & Selenium-ICP-Acid Digest & $\mu g / g$ & 88.60 & $<1.00=-01$ & $<38.30$ & $<3.93 \mathrm{el}$ & $n / a$ & $n / \mathbf{a}$ & 89.50 & 38.30 & $\mathbf{n} / \mathbf{a}$ \\
\hline S96T001690 & A & Silicon-ICP-Acid Digest & $\mu \mathrm{g} / \mathrm{g}$ & 125.0 & $7.700-01$ & $2.16 c+04$ & $2.05 e+04$ & $2.10 e+04$ & 5.23 & 72.84 & 19.10 & $\mathrm{n} / \mathbf{a}$ \\
\hline S96T001690 & A & Samsrium-ICP-Acid Digest & $\mu g / g$ & 92.60 & $<1.000-01$ & $<38.30$ & $<3.93 \mathrm{el}$ & $n / a$ & $n / \mathbf{a}$ & 91.10 & 38.30 & $\mathbf{n} / \mathbf{a}$ \\
\hline S96T001690 & $\mathbf{A}$ & Strontium-ICP-Acid Digest & $\mu \mathrm{g} / \mathrm{g}$ & 92.40 & $<1.00 \mathrm{e}-02$ & 20.10 & 20.00 & 20.05 & 0.50 & 89.04 & 3.830 & $n / a$ \\
\hline
\end{tabular}




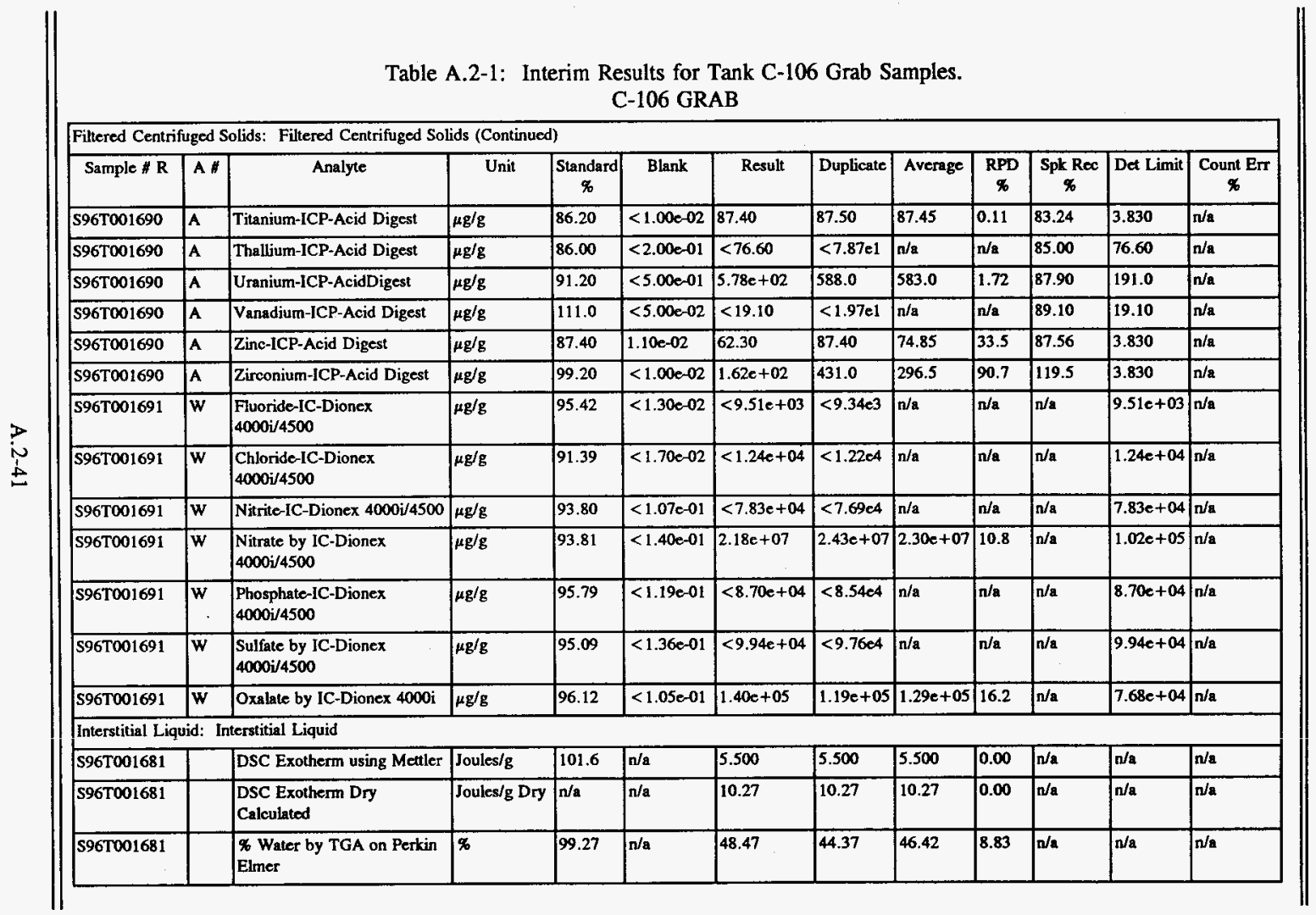




\begin{tabular}{|c|c|c|c|c|c|c|c|c|c|c|c|c|}
\hline \multicolumn{13}{|c|}{ Interstitial Liquid: Interstitial Liquid (Continued) } \\
\hline Sample \# R & A \# & Analyte & Unit & $\begin{array}{c}\text { Standard } \\
\%\end{array}$ & Blank & Result & Duplicate & Average & $\begin{array}{c}\text { RPD } \\
\%\end{array}$ & \begin{tabular}{|c|} 
Spk Rec \\
$\%$
\end{tabular} & Det Limit & $\underset{\%}{\text { Count En }}$ \\
\hline S96T001681 & & $\begin{array}{l}\text { Tot. Organic Carbon by } \\
\text { Coul. }\end{array}$ & $\mu \mathrm{g} / \mathrm{mL}$ & 93.36 & 1.300 & $2.06 \mathrm{e}+03$ & $2.08 c+03$ & $2.07 e+03$ & 0.97 & 96.30 & 55.00 & $\mathrm{n} / \mathbf{a}$ \\
\hline S96T001681 & & $\begin{array}{l}\text { TOC by Persulfatel } \\
\text { Coulometry }\end{array}$ & $\mu \mathrm{g} / \mathrm{mL}$ & 93.36 & 6.500 & $1.64 \mathrm{e}+03$ & $1.62 e+03$ & $1.63 e+03$ & 1.23 & $n / a$ & 40.00 & $n / \mathbf{a}$ \\
\hline S96T001681 & & Strontium-89/90 High Level & $\mu \mathrm{Ci} / \mathrm{mL}$ & $\mathbf{n} / \mathbf{a}$ & $\mathrm{n} / \mathbf{a}$ & $6.71 \mathrm{e}-01$ & $6.68 \mathrm{e}-0 \mathrm{t}$ & $6.69 \mathrm{e}-01$ & 0.45 & $\mathbf{n} / \mathbf{a}$ & $8.00 e-03$ & $3.75 \mathrm{E}+\infty$ \\
\hline S96T001681 & & $\begin{array}{l}\text { Pu-239/240 by TRU-SPEC } \\
\text { Resin }\end{array}$ & $\mu \mathrm{Ci} / \mathrm{mL}$ & 98.69 & $<1.67 \mathrm{e}-02$ & $8.40 \mathrm{e}-01$ & $8.34 \mathrm{e}-01$ & $8.370-01$ & 0.72 & $n / \mathbf{a}$ & $4.90 \mathrm{e}-02$ & $1.88 \mathrm{E}+00$ \\
\hline S96T001681 & D & Silver-ICP-Acid Dil. & $\mu \mathrm{g} / \mathrm{mL}$ & 98.20 & $<1.000-02$ & $<4.010$ & $<4.0100$ & $\mathrm{n} / \mathrm{a}$ & $n / a$ & 93.80 & 4.010 & $\mathrm{n} / \mathbf{a}$ \\
\hline S96T001681 & D & Aluminum-ICP-Acid Dil. & $\mu \mathrm{g} / \mathrm{mL}$ & 98.20 & $<5.000-02$ & $<20.10$ & $<2.01 \mathrm{el}$ & $n / a$ & $n / \mathbf{a}$ & 96.00 & 20.10 & $n / \mathbf{a}$ \\
\hline S96T001681 & D & Arsenic-ICP-Acid Dil. & $\mu \mathrm{g} / \mathrm{mL}$ & 102.2 & $<1.00 \mathrm{e}-01$ & $<40.10$ & $<4.01 \mathrm{el}$ & $\mathrm{n} / \mathrm{a}$ & $n / a$ & 105.7 & 40.10 & $\mathrm{n} / \mathrm{a}$ \\
\hline S96T001681 & D & Boron-ICP-Acid Dil. & $\mu \mathrm{g} / \mathrm{mL}$ & 101.0 & $<5.00 \mathrm{e}-02$ & $<20.10$ & $<2.01 \mathrm{el}$ & $\mathrm{n} / \mathrm{a}$ & $\pi / a$ & 101.3 & 20.10 & $n / \mathbf{a}$ \\
\hline S96T001681 & D & Barium-ICP-Acid Dil. & $\mu \mathrm{g} / \mathrm{mL}$ & 99.20 & $<5.00 \mathrm{e}-02$ & $<20.10$ & $<2.01 \mathrm{el}$ & $\mathrm{n} / \mathrm{a}$ & $\mathrm{n} / \mathrm{a}$ & 99.80 & 20.10 & $n / \mathbf{a}$ \\
\hline S96T001681 & D & Berylium-ICP-Acid Dil. & $\mu \mathrm{g} / \mathrm{mL}$ & 102.8 & $<5.00 \mathrm{e}-03$ & $<2.000$ & $<2.0000$ & $\mathrm{n} / \mathrm{a}$ & $n / a$ & 101.5 & 2.000 & $n / a$ \\
\hline S96T001681 & D & Bismuth-ICP-Acid Dil. & $\mu \mathrm{g} / \mathrm{mL}$ & 99.60 & $<1.00 \mathrm{e}-01$ & $<40.10$ & $<4.01 \mathrm{cl}$ & $\mathrm{n} / \mathrm{a}$ & $\mathrm{n} / \mathrm{a}$ & 90.80 & 40.10 & $n / a$ \\
\hline s96T001681 & $\mathrm{D}$ & Calcium-ICP-Acid Dil. & $\mu \mathrm{g} / \mathrm{mL}$ & 97.60 & $<1.00 \mathrm{e}-01$ & $<40.10$ & $<4.01 \mathrm{el}$ & $\mathrm{n} / \mathrm{a}$ & $n / a$ & 97.30 & 40.10 & $n / a$ \\
\hline S96T001681 & D & Cadmium-ICP-Acid Dil. & $\mu \mathrm{g} / \mathrm{mL}$ & 99.80 & $<5.00 \mathrm{e}-03$ & $<2.000$ & $<2.00 \mathrm{eO}$ & $\mathrm{n} / \mathrm{a}$ & $n / a$ & 96.00 & 2.000 & $n / a$ \\
\hline S96T001681 & D & Cerium-ICP-Acid Dil. & $\mu \mathrm{g} / \mathrm{mL}$ & 101.6 & $<1.00 c-01$ & $<40.10$ & $<4.01 \mathrm{el}$ & $n / a$ & $n / a$ & 99.30 & 40.10 & $n / a$ \\
\hline S96T001681 & D & Cobalt-ICP-Acid Dil. & $\mu \mathrm{g} / \mathrm{mL}$ & 101.8 & $<2.00 \mathrm{e}-02$ & $<8.020$ & $<8.02 e 0$ & $n / a$ & $\mathrm{n} / \mathrm{a}$ & 98.00 & 8.020 & $n / 2$ \\
\hline S96T001681 & D & Chromium-ICP-Acid Dil. & $\mu \mathrm{g} / \mathrm{mL}$ & 100.6 & $<1.00 \mathrm{e}-02$ & $<4.010$ & $<4.0100$ & $n / a$ & $n / a$ & 98.30 & 4.010 & $\mathbf{n} / \mathbf{a}$ \\
\hline S96T001681 & D & Copper-ICP-Acid Dil. & $\mu \mathrm{g} / \mathrm{mL}$ & 100.6 & $<1.00 \mathrm{e}-02$ & $<4.010$ & $<4.0100$ & $n / a$ & $n / a$ & 99.80 & 4.010 & $n / a$ \\
\hline S96T001681 & D & Iron-ICP-Acid Dil. & $\mu \mathrm{g} / \mathrm{mL}$ & 100.0 & $<5.00 \mathrm{e}-02$ & $<20.10$ & $<2.01 \mathrm{el}$ & $n / a$ & $\mathrm{n} / \mathrm{a}$ & 101.8 & 20.10 & $n / a$ \\
\hline S96T001681 & D & Potassium-ICP-Acid Dil. & $\mu \mathrm{g} / \mathrm{mL}$ & 101.2 & $<5.00-01$ & $5.41 e+02$ & 533.0 & 537.0 & 1.49 & 98.30 & 200.0 & $n / a$ \\
\hline S96T001681 & D & Lanthanum-ICP-Acid Dil. & $\mu \mathrm{g} / \mathrm{mL}$ & 98.60 & $<5.000-02$ & $\mid<20.10$ & $<2.01 \mathrm{el}$ & $\mathrm{n} / \mathrm{a}$ & $n / a$ & 98.50 & 20.10 & $\mathbf{n} / \mathbf{a}$ \\
\hline
\end{tabular}


Table A.2-1: Interim Results for Tank C-106 Grab Samples.

C-106 GRAB

Interstitial Liquid: Interstitial Liquid (Continued)

\begin{tabular}{|c|c|c|c|c|c|c|c|c|c|c|c|c|}
\hline Sample \# $\mathrm{R}$ & A" & Analyte & Unit & $\begin{array}{c}\text { Standard } \\
\%\end{array}$ & Blank & Result & Duplicate & Average & $\begin{array}{c}\text { RPD } \\
\%\end{array}$ & $\begin{array}{c}\text { Spk Rec } \\
\%\end{array}$ & Det Limit & $\begin{array}{c}\text { Count Err } \\
\%\end{array}$ \\
\hline S96T001681 & $\mathrm{D}$ & Lithium-ICP-Acid Dil. & $\mu \mathrm{g} / \mathrm{mL}$ & 100.4 & $<1.00 \mathrm{e}-02$ & $<4.010$ & $<4.0100$ & $\mathrm{n} / \mathrm{a}$ & $n / \mathbf{a}$ & 95.50 & 4.010 & $n / a$ \\
\hline S96T001681 & D & Magnesium-ICP-Acid Dil. & $\mu \mathrm{g} / \mathrm{mL}$ & 98.20 & $<1.00 \mathrm{e}-01$ & $<40.10$ & $<4.01 \mathrm{e} 1$ & $\mathrm{n} / \mathrm{a}$ & $n / \mathbf{a}$ & 94.80 & 40.10 & $n / \mathbf{a}$ \\
\hline S96T001681 & D & Manganese-ICP-Acid Dil. & $\mu \mathrm{g} / \mathrm{mL}$ & 100.0 & $<1.00 \mathrm{e}-02$ & $<4.010$ & $<4.0100$ & $n / a$ & $\mathrm{n} / \mathbf{a}$ & 98.00 & 4.010 & $\pi / \mathbf{a}$ \\
\hline S96T001681 & D & Molybdenum-ICP-Acid Dil. & $\mu \mathrm{g} / \mathrm{mL}$ & 101.8 & $<5.00 \mathrm{e}-02$ & $<20.10$ & $<2.01 \mathrm{el}$ & $\mathrm{n} / \mathrm{a}$ & $n / \mathbf{a}$ & 104.0 & 20.10 & $n / a$ \\
\hline S96T001681 & D & Sodium-ICP-Acid Dil. & $\mu \mathrm{g} / \mathrm{mL}$ & 99.40 & $<1.00 \mathrm{e}-01$ & $9.91 \mathrm{e}+04$ & $9.56 \mathrm{e}+04$ & $9.74 e+04$ & 3.60 & $n / \mathbf{a}$ & 40.10 & $n / \mathbf{a}$ \\
\hline \$96T001681 & D & Noodymium-ICP-Acid Dil. & $\mu \mathrm{g} / \mathrm{mL}$ & 99.80 & $<1.00 \mathrm{e}-01$ & $<40.10$ & $<4.01 \mathrm{el}$ & $\mathrm{n} / \mathrm{a}$ & $\mathbf{n} / \mathbf{a}$ & 104.7 & 40.10 & $\pi / \mathbf{a}$ \\
\hline S96T001681 & D & Nickel-ICP-Acid Dil. & $\mu \mathrm{g} / \mathrm{mL}$ & 99.80 & $<2.000-02$ & 11.50 & 11.30 & 11.40 & 1.75 & 96.60 & 8.020 & $n / a$ \\
\hline S96T001681 & D & Phosphorus-ICP-Acid Dil. & $\mu \mathrm{g} / \mathrm{mL}$ & 102.0 & $<2.00 \mathrm{e}-01$ & $2.66 e+02$ & 275.0 & 270.5 & 3.33 & 103.1 & 80.20 & $\ln / \mathbf{a}$ \\
\hline S96T001681 & D & Lead-ICP-Acid Dil. & $\mu \mathrm{g} / \mathrm{mL}$ & 99.20 & $<1.00 \mathrm{e}-01$ & $<<40.10$ & $<4.01 e 1$ & $n / a$ & $n / \mathbf{a}$ & 98.30 & 40.10 & $n / 2$ \\
\hline S96T001681 & D & Sulfur-ICP-Acid Dil. & $\mu \mathrm{g} / \mathrm{mL}$ & 100.2 & $<1.00 \mathrm{c}-01$ & $2.24 e+03$ & $2.15 e+03$ & $2.20 c+03$ & 4.10 & 79.60 & 40.10 & $n / a$ \\
\hline S96T001681 & D & Antimony-ICP-Acid Dil. & $\mu \mathrm{g} / \mathrm{mL}$ & 95.40 & $<6.00 \mathrm{e}-02$ & $<24.10$ & $<2.41 \mathrm{el}$ & $\mathrm{n} / \mathrm{a}$ & $n / a$ & 91.00 & 24.10 & $n / a$ \\
\hline 596T001681 & D & Selenium-ICP-Acid Dil. & $\mu \mathrm{g} / \mathrm{mL}$ & 103.6 & $<1.00 \mathrm{e}-01$ & $<40.10$ & $<4.01 \mathrm{e} 1$ & $n / a$ & $n / a$ & 118.7 & 40.10 & $n / a$ \\
\hline S96T001681 & D & Silicon-ICP-Acid Dil. & $\mu \mathrm{g} / \mathrm{mL}$ & 95.40 & $<5.00 \mathrm{e}-02$ & 27.50 & 20.40 & 23.95 & 29.6 & 92.90 & 20.10 & $n / a$ \\
\hline S96T001681 & D & Samarium-ICP-Acid Dil. & $\mu \mathrm{g} / \mathrm{mL}$ & 99.60 & $<1.00 \mathrm{e}-01$ & $<40.10$ & $<4.01 \mathrm{el}$ & $n / a$ & $n / a$ & 102.5 & 40.10 & $n / a$ \\
\hline S96T001681 & D & Strontium-ICP-Acid Dil. & $\mu \mathrm{g} / \mathrm{mL}$ & 99.20 & $<1.006-02$ & $<4.010$ & $<4.0100$ & $n / a$ & $n / a$ & 99.50 & 4.010 & $\pi / a$ \\
\hline S96T001681 & D & Titanium-ICP-Acid Dil. & $\mu \mathrm{g} / \mathrm{mL}$ & 98.20 & $<1.00 c-02$ & $<4.010$ & $<4.01 \mathrm{e} 0$ & $n / a$ & $n / \mathbf{a}$ & 97.50 & 4.010 & $n / a$ \\
\hline S96T001681 & D & Thallium-ICP-Acid Dil. & $\mu \mathrm{g} / \mathrm{mL}$ & 96.00 & $<2.00<-01$ & $<80.20$ & $<8.02 \mathrm{el}$ & $n / a$ & $n / a$ & 92.00 & 80.20 & $n / a$ \\
\hline S967001681 & D & Uranium-ICP-Acid Dil. & $\mu \mathrm{g} / \mathrm{mL}$ & 96.60 & $<5.00 \mathrm{e}-01$ & $1.60 e+03$ & $1.50 c+03$ & $1.55 e+03$ & 6.45 & 98.85 & 200.0 & $\mathbf{n} / \mathbf{a}$ \\
\hline S96T001681 & D & Vanadium-ICP-Acid Dil. & $\mu \mathrm{g} / \mathrm{mL}$ & 101.2 & $<5.00 \mathrm{e}-02$ & $<20.10$ & $<2.01 \mathrm{e1}$ & $n / a$ & $n / a$ & 99.30 & 20.10 & $n / a$ \\
\hline S96T001681 & D & Zinc-ICP-Acid Dil. & $\mu \mathrm{g} / \mathrm{mL}$ & 102.2 & $<1.00 e-02$ & $<4.010$ & $<4.0100$ & $n / a$ & $n / a$ & 97.50 & 4.010 & $n / \mathbf{a}$ \\
\hline \$96T001681 & D & Zirconium-ICP-Acid Dil. & $\mu \mathrm{g} / \mathrm{mL}$ & 98.60 & $<1.00 c-02$ & $3.30 e+02$ & 319.0 & 324.5 & 3.39 & 98.70 & 4.010 & $n / \mathbf{a}$ \\
\hline
\end{tabular}


Table A.2-1: Interim Results for Tank C-106 Grab Samples.

C-106 GRAB

Interstitial Liquid: Interstitial Liquid (Continued)

\begin{tabular}{|c|c|c|c|c|c|c|c|c|c|c|c|c|}
\hline Sample \# R & $A \#$ & Analyte & Unit & $\begin{array}{c}\text { Standard } \\
\%\end{array}$ & Blank & Result & Duplicate & Average & $\begin{array}{c}\text { RPD } \\
\%\end{array}$ & $\begin{array}{c}\text { Spk Rec } \\
\%\end{array}$ & Det Limit & $\begin{array}{c}\text { Count E } \\
\%\end{array}$ \\
\hline S96T001681 & & Cobalt- 60 by GEA & $\mu \mathrm{Ci} / \mathrm{mL}$ & 97.28 & $<3.26 e-04$ & $<5.05 \mathrm{e}-03$ & $<4.80<-3$ & $n / \mathbf{a}$ & $n / a$ & $n / a$ & $5.000-03$ & $n / a$ \\
\hline \$96T001681 & & Cesium- 137 by GEA & $\mu \mathrm{Ci} / \mathrm{mL}$ & 97.05 & $1.00<-03$ & $1.21 e+02$ & 121.0 & 121.0 & 0.00 & $n / a$ & $\mathbf{n} / \mathbf{a}$ & 0.140 \\
\hline
\end{tabular}

Potential Organic Layer: Potential Organic Layer

\begin{tabular}{|l|l|l|l|l|l|l|l|l|l|l|l|l|l|l|l|l}
\hline S967001679 & & DSC Exotherm using Metler & Joules/g & 93.85 & $n / a$ & $0.00 e+\infty$ & $0.00 e+00$ & $0.00 e+\infty$ & 0.00 & $n / a$ & $n / a$
\end{tabular}

\begin{tabular}{|c|c|c|c|c|c|c|c|c|c|c|c|}
\hline & & & & & & & & & & & \\
\hline S96T001679 & $\begin{array}{l}\text { DSC Exotherm Dry } \\
\text { Calculated }\end{array}$ & Joules/g Dry & $n / 2$ & $n / a$ & $0.00 e+\infty 0$ & $0.00 e+\infty$ & $0.00 e+\infty$ & 0.00 & $\mathrm{n} / \mathrm{a}$ & $n / \mathbf{a}$ & $n / a$ \\
\hline S96T001679 & $\begin{array}{l}\text { \% Water by TGA using } \\
\text { Mettler }\end{array}$ & $\%$ & 101.2 & $\mathrm{n} / \mathrm{a}$ & 28.37 & 31.34 & 29.86 & 9.95 & $n / a$ & $\mathbf{n} / \mathbf{a}$ & $n / a$ \\
\hline S96T001679 & $\begin{array}{l}\text { TOC by } \\
\text { Persulfate/Coulometry }\end{array}$ & $\mu \mathrm{g} / \mathrm{mL}$ & 94.03 & 3.000 & $2.48 e+04$ & $2.20 e+04$ & $2.34 c+04$ & 12.0 & $n / a$ & 40.00 & $\mathrm{n} / \mathrm{a}$ \\
\hline S96T002635 & $\begin{array}{l}\text { Pu-239/240 by TRU-SPEC } \\
\text { Resin }\end{array}$ & $\mu \mathrm{Ci} / \mathrm{g}$ & 99.21 & $<3.10 e-02$ & $3.63 \mathrm{e}-01$ & $3.57 \mathrm{e}-01$ & $3.60 \mathrm{c}-01$ & 1.67 & $\mathrm{n} / \mathrm{a}$ & $2.80 \mathrm{c}-02$ & $2.19 \mathrm{E}+00$ \\
\hline$\$ 96 T 002635$ & Pu-238 by Ion Exchange & $\mu \mathrm{Ci} / \mathrm{g}$ & $\mathrm{n} / \mathrm{a}$ & $<3.10 c-02$ & $1.120-01$ & $1.00 e-01$ & $1.06 e-01$ & 11.3 & $n / a$ & $2.800-02$ & $3.22 \mathrm{E}+00$ \\
\hline
\end{tabular}

Sludge (from Liquid Grab Sample): Sludge (from Liquid Grab Sample)

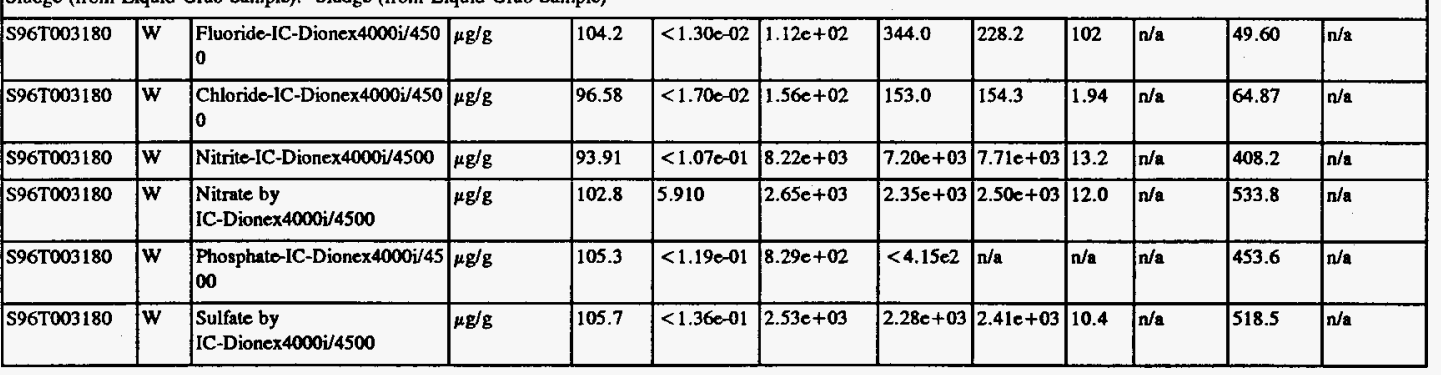


Table A.2-1: Interim Results for Tank C-106 Grab Samples.

C-106 GRAB

\begin{tabular}{|c|c|c|c|c|c|c|c|c|c|c|c|c|}
\hline Sample \# R & A & Analyte & Unit & \begin{tabular}{|c|} 
Standard \\
$\%$
\end{tabular} & Blank & Result & Duplicale & Average & $\begin{array}{c}\text { RPD } \\
*\end{array}$ & $\underset{\%}{\text { Spk Rec }}$ & Det Limit & $\begin{array}{c}\text { Count Err } \\
\%\end{array}$ \\
\hline$\$ 96 T 003180$ & $\mathbf{w}$ & Oxalate by IC-Dionex $4000 \mathrm{i}$ & $\mu \mathrm{g} / \mathrm{g}$ & 105.3 & $<1.05001$ & $7.82 c+04$ & $2.26 c+05$ & $1.52 t+05$ & 97.2 & $n / \mathbf{a}$ & 400.6 & $n / \mathbf{a}$ \\
\hline \multicolumn{13}{|l|}{ RISER: 7} \\
\hline \multicolumn{13}{|c|}{ SEGMENT \#: 6C-96-12 } \\
\hline \multicolumn{13}{|c|}{ SEGMENT PORTION: Supernate } \\
\hline S96T001023 & & DSC Exotherm using Mettler & Joules/g & 108.3 & $\mathbf{n} / \mathbf{a}$ & $0.00 e+\infty 0$ & $0.00 e+00$ & $0.00 e+\infty$ & 0.00 & $n / a$ & $n / \mathbf{a}$ & $n / \mathbf{a}$ \\
\hline $596 \mathrm{T001023}$ & & $\begin{array}{l}\text { DSC Exotherm Dry } \\
\text { Calculated }\end{array}$ & Joules/g Dry & $n / \mathbf{a}$ & $n / a$ & $0.00 e+\infty 0$ & $0.00 e+\infty$ & $0.00 e+\infty$ & 0.00 & $n / 2$ & $n / a$ & $n / \mathbf{a}$ \\
\hline \$96T001023 & & $\begin{array}{l}\text { Ammonia by ISE-Std } \\
\text { Additions }\end{array}$ & $\mu \mathrm{g} / \mathrm{mL}$ & 96.84 & 3.100 & $<5.000$ & $<5$ & $n / a$ & $n / \mathbf{a}$ & 99.00 & 5.000 & $n / a$ \\
\hline S96T001023 & & pH Direct & $\mathrm{pH}$ & $n / a$ & $\mathrm{n} / \mathbf{a}$ & 10.24 & 10.24 & 10.24 & 0.06 & $n / \mathbf{n}$ & $1.000-02$ & $n / a$ \\
\hline S967001023 & & Specific Gravity & Sp.G. & 98.45 & $n / a$ & 1.173 & 1.193 & 1.183 & 1.69 & $n / \mathbf{a}$ & $1.00=-03$ & $n / a$ \\
\hline S96T001023 & & $\begin{array}{l}\text { \% Water by TGA using } \\
\text { Mettler }\end{array}$ & $\%$ & 102.2 & $\mathbf{n} / \mathbf{a}$ & 79.05 & 79.49 & 79.27 & 0.52 & $n / 2$ & $n / a$ & $n / a$ \\
\hline S96T001023 & & Tot. Inorg. Carbon by Coul. & $\mu \mathrm{g} / \mathrm{mL}$ & 103.2 & $<5.000$ & $2.43 e+04$ & $2.46 e+04$ & $2.44 c+04$ & 1.23 & 99.00 & 105.0 & $n / a$ \\
\hline S96T001023 & & $\begin{array}{l}\text { Tot. Organic Carbon by } \\
\text { Coul. }\end{array}$ & $\mu \mathrm{g} / \mathrm{mL}$ & 99.70 & $<5.000$ & $2.49 e+03$ & $2.54 e+03$ & $2.52 e+03$ & 1.99 & 97.30 & 55.00 & $n / \mathbf{a}$ \\
\hline S96T001023 & & $\begin{array}{l}\text { TOC by Persulfatel } \\
\text { Coulometry }\end{array}$ & $\mu \mathrm{g} / \mathrm{mL}$ & 91.36 & 2.800 & $1.97 e+03$ & $2.09 e+03$ & $2.03 e+03$ & 5.91 & $n / \mathbf{a}$ & 40.00 & $n / a$ \\
\hline S96T001023 & & $\%$ Water by Gravimetric & $\%$ & 102.2 & $n / \mathbf{a}$ & 79.00 & 79.00 & 79.00 & 0.00 & $\mathbf{n} / \mathbf{a}$ & $1.000-02$ & $n / a$ \\
\hline S96T001023 & D & Silver-ICP-Acid Dil. & $\mu \mathrm{g} / \mathrm{mL}$ & 100.8 & $<1.00 \mathrm{e}-02$ & 9.210 & 9.930 & 9.570 & 7.52 & 87.10 & 6.010 & $n / \mathbf{a}$ \\
\hline $596 \mathrm{~T} 001023$ & D & Aluminum-ICP-Acid Dil. & $\mu \mathrm{g} / \mathrm{mL}$ & 98.40 & $<5.00 \mathrm{e}-02$ & $<30.00$ & $<3.00=1$ & $n / a$ & $n / a$ & 95.90 & 30.10 & $n / a$ \\
\hline S96T001023 & D & Barium-ICP-Acid Dil. & $\mu \mathrm{g} / \mathrm{mL}$ & 102.6 & $<5.00<-02$ & $<30.00$ & $<3.00 \mathrm{e} 1$ & $n / a$ & $n / a$ & 95.80 & 30.10 & $a / \mathbf{a}$ \\
\hline$\$ 967001023$ & D & Beryllium-ICP-Acid Dil. & $\mu \mathrm{g} / \mathrm{mL}$ & 104.0 & $<5.000 .03$ & $<3.000$ & $<3.00<0$ & $\mathbf{n} / \mathbf{a}$ & $n / a$ & 99.40 & 3.000 & $n / a$ \\
\hline
\end{tabular}




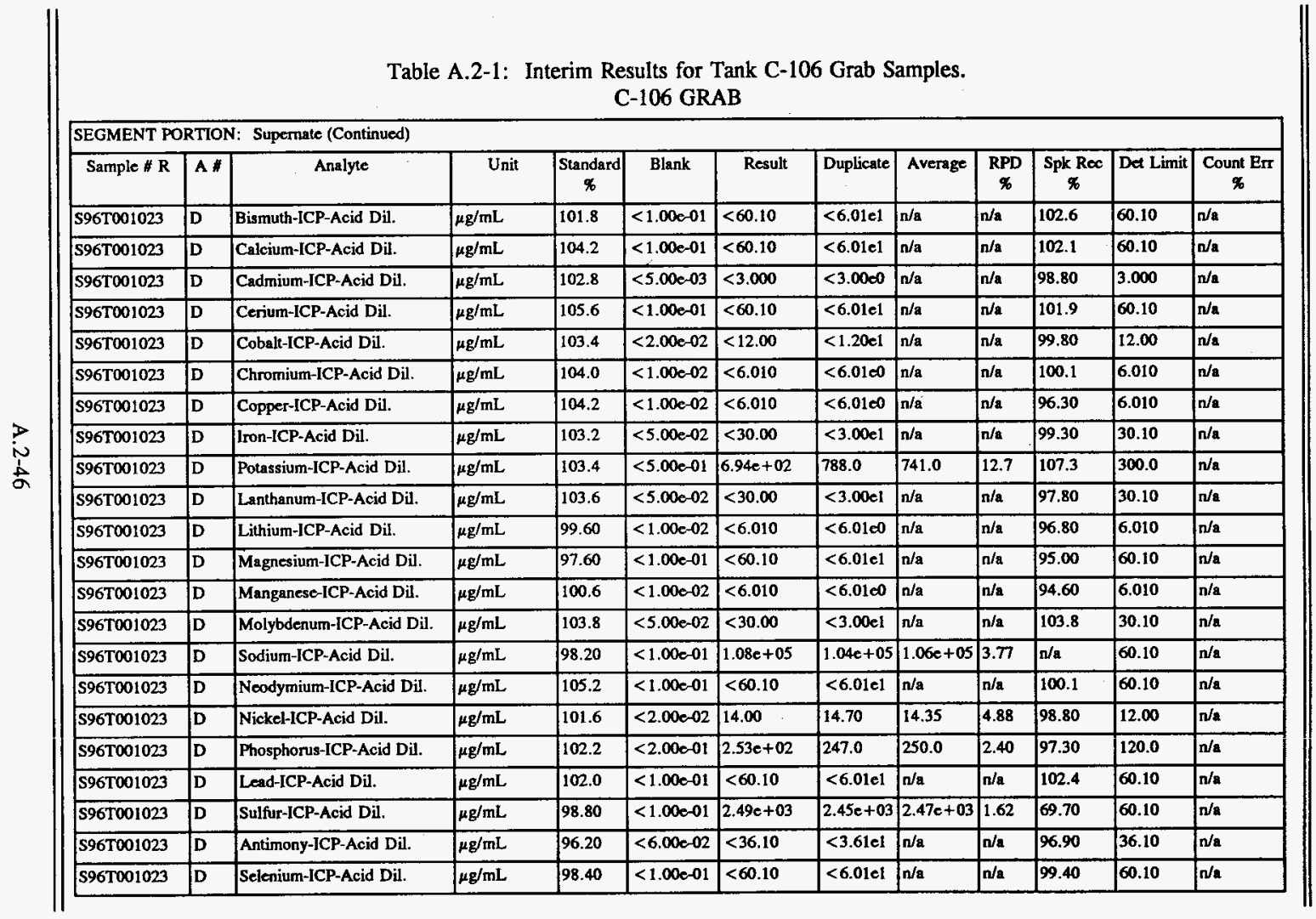


Table A.2-1: Interim Results for Tank C-106 Grab Samples.

C-106 GRAB

SEGMENT PORTION: Supernate (Continued)

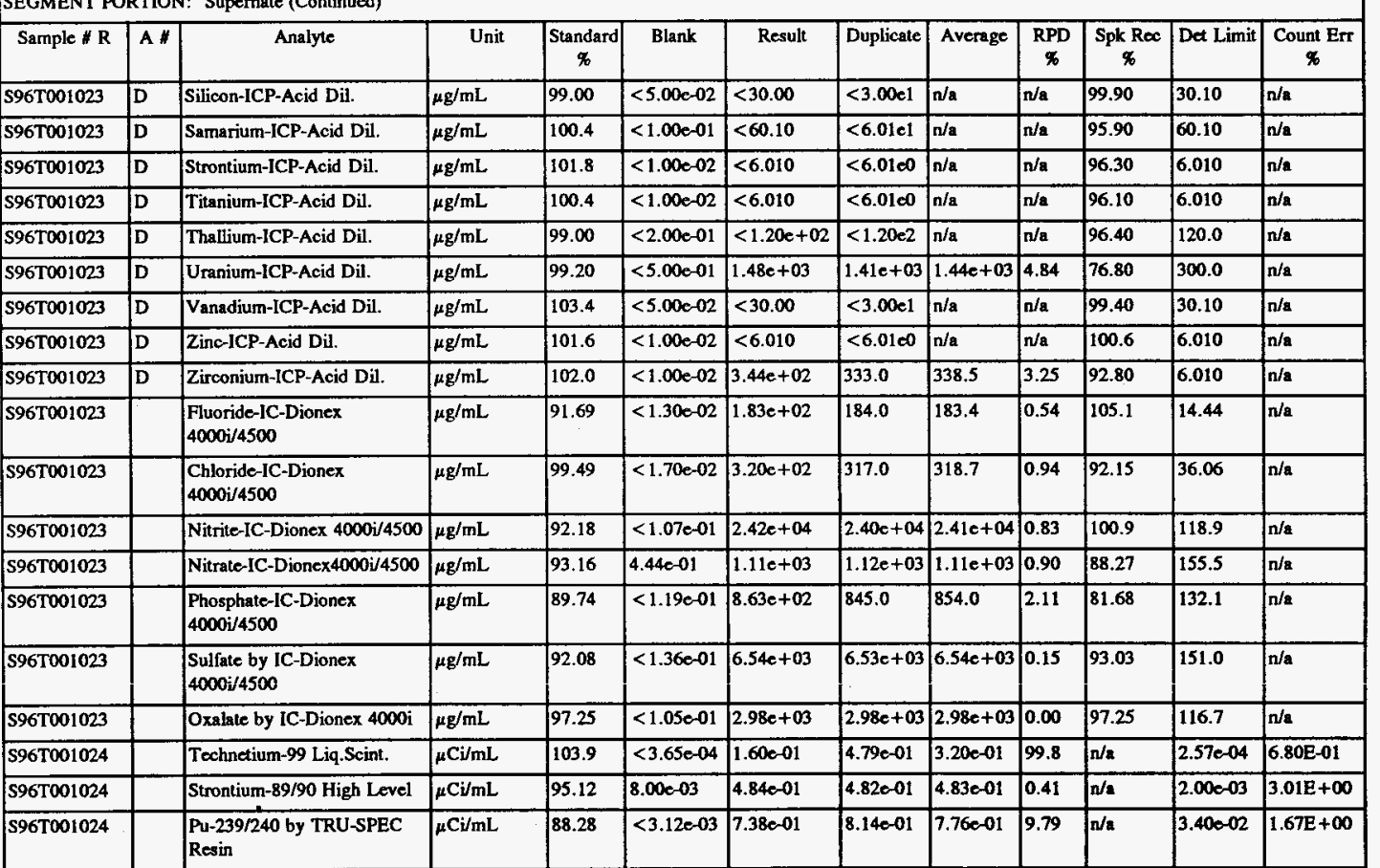


Table A.2-1: Interim Results for Tank C-106 Grab Samples.

C-106 GRAB

SEGMENT PORTION: Supernate (Continued)

\begin{tabular}{|c|c|c|c|c|c|c|c|c|c|c|c|c|}
\hline Sample \# R & A \# & Analyte & Unit & $\begin{array}{c}\text { Standard } \\
\text { \% }\end{array}$ & Blank & Result & Duplicate & Average & $\begin{array}{c}\text { RPD } \\
\%\end{array}$ & $\begin{array}{c}\text { Spk Rec } \\
\%\end{array}$ & Det Limit & $\begin{array}{c}\text { Count Err } \\
\%\end{array}$ \\
\hline S96T001024 & & Cobalt -60 by GEA & $\mu \mathrm{Ci} / \mathrm{mL}$ & 99.23 & $<1.99 \mathrm{e}-05$ & $<6.19 \mathrm{e}-03$ & $<5.55 \mathrm{e}-3$ & $\mathrm{n} / \mathbf{a}$ & $\mathbf{n} / \mathbf{a}$ & $n / a$ & $6.00 c-03$ & $n / a$ \\
\hline S96T001024 & & Cesium- 137 by GEA & $\mu \mathrm{Ci} / \mathrm{mL}$ & 101.5 & $<5.81 \mathrm{e}-05$ & $1.08 c+02$ & 110.0 & 109.0 & 1.83 & $n / 2$ & $n / \mathbf{a}$ & 0.210 \\
\hline S96T001024 & & Am-241 by Extraction & $\mu \mathrm{Ci} / \mathrm{mL}$ & 80.13 & $<1.15 e-02$ & $<1.13 \mathrm{e}-02$ & $<1.28 \mathrm{E}-2$ & $n / a$ & $n / \mathbf{a}$ & $n / a$ & $1.10 \mathrm{e}-02$ & $5.59 \mathrm{E}+00$ \\
\hline S96T001024 & & Alpha in Liquid Samples & $\mu \mathrm{Ci} / \mathrm{mL}$ & 88.23 & $<4.98 \mathrm{e}-03$ & $9.280-01$ & $8.80 \mathrm{e}-01$ & $9.04 a-01$ & 5.31 & 92.86 & $1.200-02$ & $5.11 \mathrm{E}+00$ \\
\hline
\end{tabular}

RISER: 7

SEGMENT \#: 6C-96-13

SEGMENT PORTION: Centrifuged Solids (Grab Sample)

\begin{tabular}{|c|c|c|c|c|c|c|c|c|c|c|c|c|}
\hline S96T001030 & & Bulk Density of Sample & $\mathrm{g} / \mathrm{mL}$ & $n / a$ & $n / a$ & 1.520 & $n / a$ & $\mathrm{n} / \mathrm{a}$ & $n / a$ & $n / a$ & $5.000-01$ & $n / \mathbf{a}$ \\
\hline S96T001030 & & DSC Exotherm using Metter & Joules/g & 112.1 & $n / a$ & $1.81 e+02$ & 258.9 & 219.9 & 35.5 & $n / a$ & $n / a$ & $\mathrm{n} / \mathbf{a}$ \\
\hline \$96T001030 & & $\begin{array}{l}\text { DSC Exotherm Dry } \\
\text { Calculated }\end{array}$ & Joules/g Dry & $n / a$ & $n / a$ & $2.00 c+02$ & 285.6 & 242.6 & 35.4 & $\mathrm{n} / \mathbf{a}$ & $n / a$ & $n / a$ \\
\hline$\$ 96 \mathrm{~T} 001030$ & & $\begin{array}{l}\% \text { Water by TGA on Perkin } \\
\text { Elmer }\end{array}$ & $\%$ & 99.16 & $\mathrm{n} / \mathrm{a}$ & 9.240 & 9.480 & 9.360 & 2.56 & $n / a$ & $n / a$ & $\mathrm{n} / \mathrm{a}$ \\
\hline S96T001030 & & Volume $\%$ Solids & $\%$ & $n / a$ & $\mathbf{n} / \mathbf{a}$ & 67.30 & $\mathbf{n} / \mathbf{a}$ & $n / a$ & $n / a$ & $n / 2$ & $n / 8$ & $n / a$ \\
\hline S96T001030 & & \%Water by Gravimetric & $\%$ & 98.99 & $n / a$ & 19.30 & 22.40 & 20.85 & 14.9 & $n / a$ & $1.00 \mathrm{e}-02$ & $n / a$ \\
\hline \multicolumn{13}{|c|}{ Control Sample: Control Sample } \\
\hline S96T001034 & & DSC Exotherm using Mettler & Joules/g & 100.9 & $\mathbf{n} / \mathbf{a}$ & 87.40 & 66.70 & 77.05 & 26.9 & $\mathrm{n} / \mathbf{a}$ & $n / a$ & $n / a$ \\
\hline S96T001034 & & $\begin{array}{l}\text { DSC Exotherm Dry } \\
\text { Calculated }\end{array}$ & Joules/g Dry & $n / 2$ & $n / a$ & $1.27 e+02$ & 96.81 & 111.9 & 26.9 & $n / a$ & $n / a$ & $n / a$ \\
\hline \$96T001034 & & $\begin{array}{l}\text { \% Water by TGA using } \\
\text { Mettler }\end{array}$ & $\%$ & 99.43 & $n / a$ & 31.29 & 30.91 & 31.10 & 1.22 & $\mathbf{n} / \mathbf{a}$ & $n / a$ & $n / a$ \\
\hline S96T001036 & $\mathbf{F}$ & Technetium-99 Liq.Scint. & $\mu \mathrm{Ci} / \mathrm{g}$ & 102.9 & $<1.62 e-02$ & $3.59 \mathrm{e}-02$ & $2.41 \mathrm{e}-02$ & $3.000-02$ & 39.3 & $n / a$ & $1.70 c-02$ & $6.45 \mathrm{E}+00$ \\
\hline S96T001036 & $\mathbf{F}$ & Strontium-89/90 High Level & $\mu \mathrm{Ci} / \mathrm{g}$ & 99.19 & $6.97 e-01$ & $1.24 c+03$ & 483.0 & 861.5 & 87.9 & $n / \mathbf{a}$ & $1.87 \mathrm{e}-01$ & $4.24 \mathrm{E}-01$ \\
\hline
\end{tabular}


Table A.2-1: Interim Results for Tank C-106 Grab Samples.

C-106 GRAB

\begin{tabular}{|c|c|c|c|c|c|c|c|c|c|c|c|c|}
\hline \multicolumn{13}{|c|}{ Control Sample: Control Sample (Continued) } \\
\hline Sample \# R & A \# & Analyte & Unit & $\begin{array}{c}\text { Standard } \\
\%\end{array}$ & Blank & Result & Duplicate & Average & $\begin{array}{c}\text { RPD } \\
\%\end{array}$ & $\underset{\%}{\text { Spk Rec }}$ & Dat Limit & $\begin{array}{c}\text { Count Ert } \\
\%\end{array}$ \\
\hline $596 \mathrm{T001036}$ & $\mathbf{F}$ & $\begin{array}{l}\text { Pu-239/240 by TRU-SPEC } \\
\text { Resin }\end{array}$ & $\mu \mathrm{Ci} / \mathrm{g}$ & 97.90 & $<1.600-02$ & 1.200 & $8.95 \mathrm{e}-01$ & 1.047 & 29.1 & $n / 2$ & $6.800-02$ & $1.82 \mathrm{E}+\infty 0$ \\
\hline S96T001036 & $F$ & Cobalt -60 by GEA & $\mu \mathrm{Ci} / \mathrm{g}$ & 101.4 & $<4.12 \mathrm{e}-01$ & $<5.75 \mathrm{e}-01$ & $<5.58 \mathrm{e}-1$ & $n / a$ & $n / a$ & $\mathbf{n} / \mathbf{a}$ & $5.75 \mathrm{e}-01$ & $\mathbf{n} / \mathbf{a}$ \\
\hline$\$ 96 \mathrm{T001036}$ & $\mathbf{F}$ & Cesium-137 by GEA & $\mu \mathrm{Ci} / g$ & 103.2 & $<4.46 e-01$ & $8.99 e+02$ & 716.0 & 807.6 & 22.7 & $\mathbf{n} / \mathbf{a}$ & $n / a$ & 0.810 \\
\hline S96T001036 & $\mathbf{F}$ & Am-241 by Extraction & $\mu \mathrm{Ci} / \mathrm{g}$ & 101.0 & $<1.28 c-02$ & 1.460 & 1.210 & 1.335 & 18.7 & $n / a$ & $1.20 \mathrm{c}-01$ & $2.62 \mathrm{E}+00$ \\
\hline S96'T001036 & $\mathrm{F}$ & Alpha of Digested Solid & $\mu \mathrm{Ci} / \mathrm{g}$ & 114.8 & $<6.30 \mathrm{e}-02$ & 6.330 & 2.420 & 4.375 & 89.4 & 96.66 & $1.090-01$ & $6.97 \mathrm{E}+00$ \\
\hline \multicolumn{13}{|c|}{ Decanted Supernate (Liquid Grab Sludge): Decanted Supernate (Liquid Grab Sludge) } \\
\hline S96T001032 & & Specific Gravity & Sp.G. & $\mathbf{n} / \mathbf{a}$ & $n / a$ & I.S. & I.S. & $n / \mathbf{a}$ & $\mathrm{n} / \mathrm{a}$ & $\mathbf{n} / \mathbf{a}$ & 1.00003 & $\mathrm{n} / \mathrm{a}$ \\
\hline S96T002025 & & pH Direct & $\mathrm{pH}$ & $\mathbf{n} / \mathbf{a}$ & $n / a$ & 10.09 & $n / \mathbf{a}$ & $\mathbf{n} / \mathbf{a}$ & $n / a$ & $\mathbf{n} / \mathbf{a}$ & $1.000-02$ & $\mathrm{n} / \mathrm{a}$ \\
\hline \$96T002025 & & $\begin{array}{l}\text { Tot. Organic Carbon by } \\
\text { Coul. }\end{array}$ & $\mu \mathrm{g} / \mathrm{mL}$ & 100.0 & $1.00 \mathrm{e}-01$ & $1.95 e+03$ & $1.95 \mathrm{e}+03$ & $1.95 e+03$ & 0.00 & 103.0 & 55.00 & $n / a$ \\
\hline$\$ 96 \mathrm{~T} 002025$ & & $\begin{array}{l}\text { Pu-239/240 by TRU-SPEC } \\
\text { Resin }\end{array}$ & $\mu \mathrm{Ci} / \mathrm{mL}$ & 96.33 & $<3.33 \mathrm{e}-03$ & $7.73 e-01$ & $7.66 \mathrm{e}-01$ & $7.70 c-01$ & 0.91 & $\mathrm{n} / \mathrm{a}$ & $3.80=-02$ & $1.66 \mathrm{E}+\infty 0$ \\
\hline $596 \mathrm{~T} 002025$ & & $\begin{array}{l}\text { Fhooride-IC-Dionex } \\
4000 \mathrm{i} / 4500\end{array}$ & $\mu \mathrm{g} / \mathrm{mL}$ & 98.98 & $<1.30 e-02$ & $1.91 \mathrm{e}+02$ & 209.0 & 200.2 & 9.00 & $\mathrm{n} / \mathrm{a}$ & 14.44 & $n / a$ \\
\hline S96T002025 & & $\begin{array}{l}\text { Chloride-IC-Dionex } \\
4000 \mathrm{i} / 4500\end{array}$ & $\mu \mathrm{g} / \mathrm{mL}$ & 99.75 & $<1.700-02$ & $2.82 e+02$ & 293.0 & 287.2 & 3.83 & $n / a$ & 18.89 & $n / a$ \\
\hline 5967002025 & & Nitrite-IC-Dionex $4000 \mathrm{j} / 4500$ & $\mu \mathrm{g} / \mathrm{mL}$ & 103.5 & $<1.07 \mathrm{e}-01$ & $2.74 c+04$ & $3.05 e+04$ & $2.90 c+04$ & 10.7 & $n / a$ & 118.9 & $n / a$ \\
\hline S96T002025 & & Nitrate-IC-Dionex $4000 \mathrm{j} / 4500$ & $\mu \mathrm{g} / \mathrm{mL}$ & 103.1 & $<1.40 \mathrm{e}-01$ & $9.69 e+02$ & $1.10 e+03$ & $1.03 e+03$ & 12.7 & $n / a$ & 155.5 & $n / a$ \\
\hline \$96T002025 & & $\begin{array}{l}\text { Phosphate-IC-Dionex } \\
4000 \mathrm{i} / 4500\end{array}$ & $\mu \mathrm{g} / \mathrm{mL}$ & 103.5 & $<1.19 \mathrm{e}-01$ & $4.88 e+02$ & 558.0 & 522.8 & 13.4 & $n / a$ & 132.1 & $n / a$ \\
\hline S96TC02025 & & $\begin{array}{l}\text { Sulfate by IC-Dionex } \\
4000 \mathrm{i} / 4500\end{array}$ & $\mu \mathrm{g} / \mathrm{mL}$ & 101.6 & $<1.360-01$ & $7.19 c+03$ & $7.98 e+03$ & $7.58 c+03$ & 10.4 & $n / a$ & 151.0 & $n / a$ \\
\hline$\$ 967002025$ & & Oxalate by IC-Dionex $4000 \mathrm{i}$ & $\mu \mathrm{g} / \mathrm{mL}$ & 103.2 & $<1.05 \mathrm{e}-01$ & $3.11 e+03$ & $3.47 e+03$ & $3.29 e+03$ & 10.9 & $n / a$ & 116.7 & $n / a$ \\
\hline
\end{tabular}


Table A.2-1: Interim Results for Tank C-106 Grab Samples. C-106 GRAB

Decanted Supernate (Liquid Grab Sludge): Decanted Supernate (Liquid Grab Sludge) (Continued)

\begin{tabular}{|c|c|c|c|c|c|c|c|c|c|c|c|c|}
\hline Sample \# R & $A \#$ & Analyte & Unit & $\begin{array}{c}\text { Standard } \\
\%\end{array}$ & Blank & Result & Duplicate & Average & $\begin{array}{c}\text { RPD } \\
\%\end{array}$ & $\begin{array}{c}\text { Spk Rec } \\
\%\end{array}$ & Det Limit & $\begin{array}{c}\text { Count Er } \\
\%\end{array}$ \\
\hline S96T002025 & & Cobalt -60 by GEA & $\mu \mathrm{Ci} / \mathrm{mL}$ & 93.30 & $<8.67 \mathrm{e}-04$ & $<4.03 \mathrm{e}-03$ & $<4.34 \mathrm{e}-3$ & $n / a$ & $n / a$ & $n / a$ & $4.000-03$ & $n / a$ \\
\hline S96T002025 & & Cesium-137 by GEA & $\mu \mathrm{Ci} / \mathrm{mL}$ & 90.88 & $<2.68 \mathrm{e}-03$ & $1.04 e+02$ & 105.0 & 104.5 & 0.96 & $n / a$ & $n / a$ & 0.160 \\
\hline
\end{tabular}

Filtered Centrifuged Solids: Filtered Centrifuged Solids

Filtered Centrifuged Solids: Filtered Centrifuged Solids

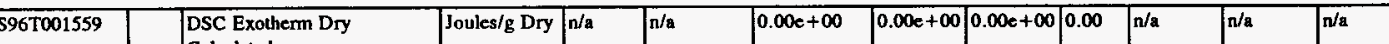

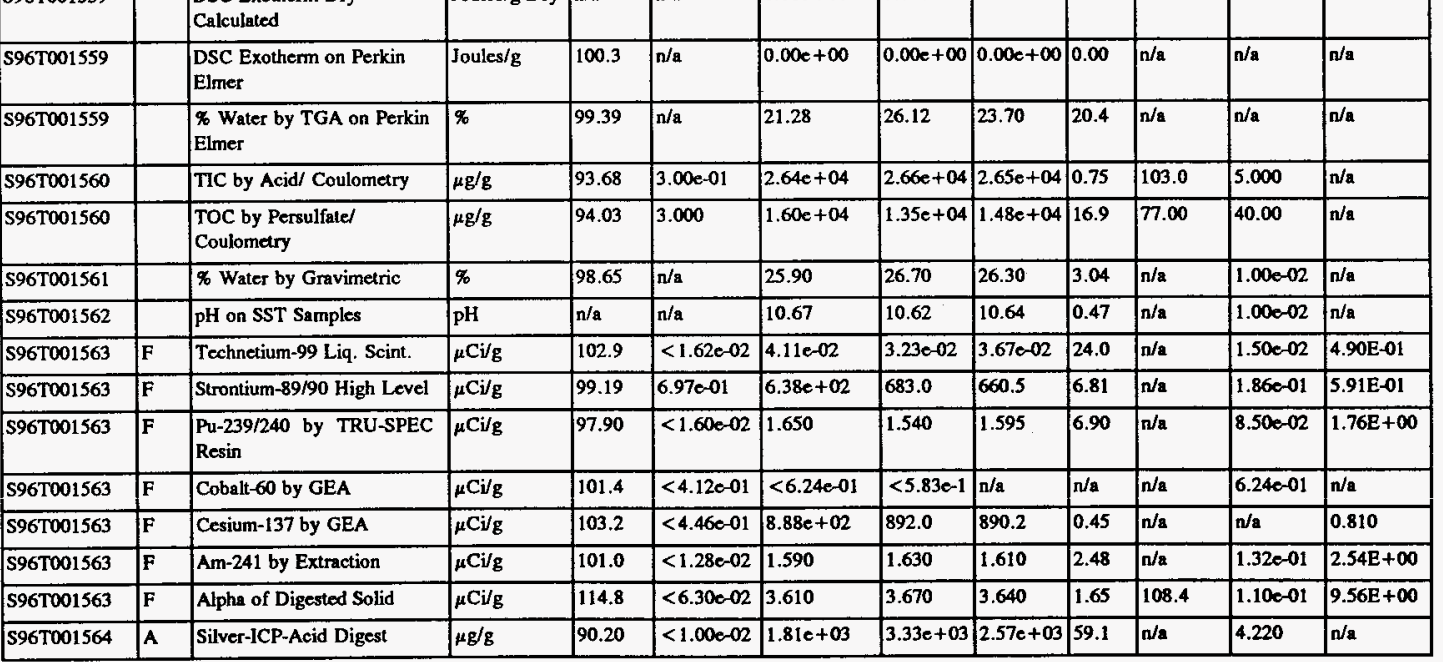




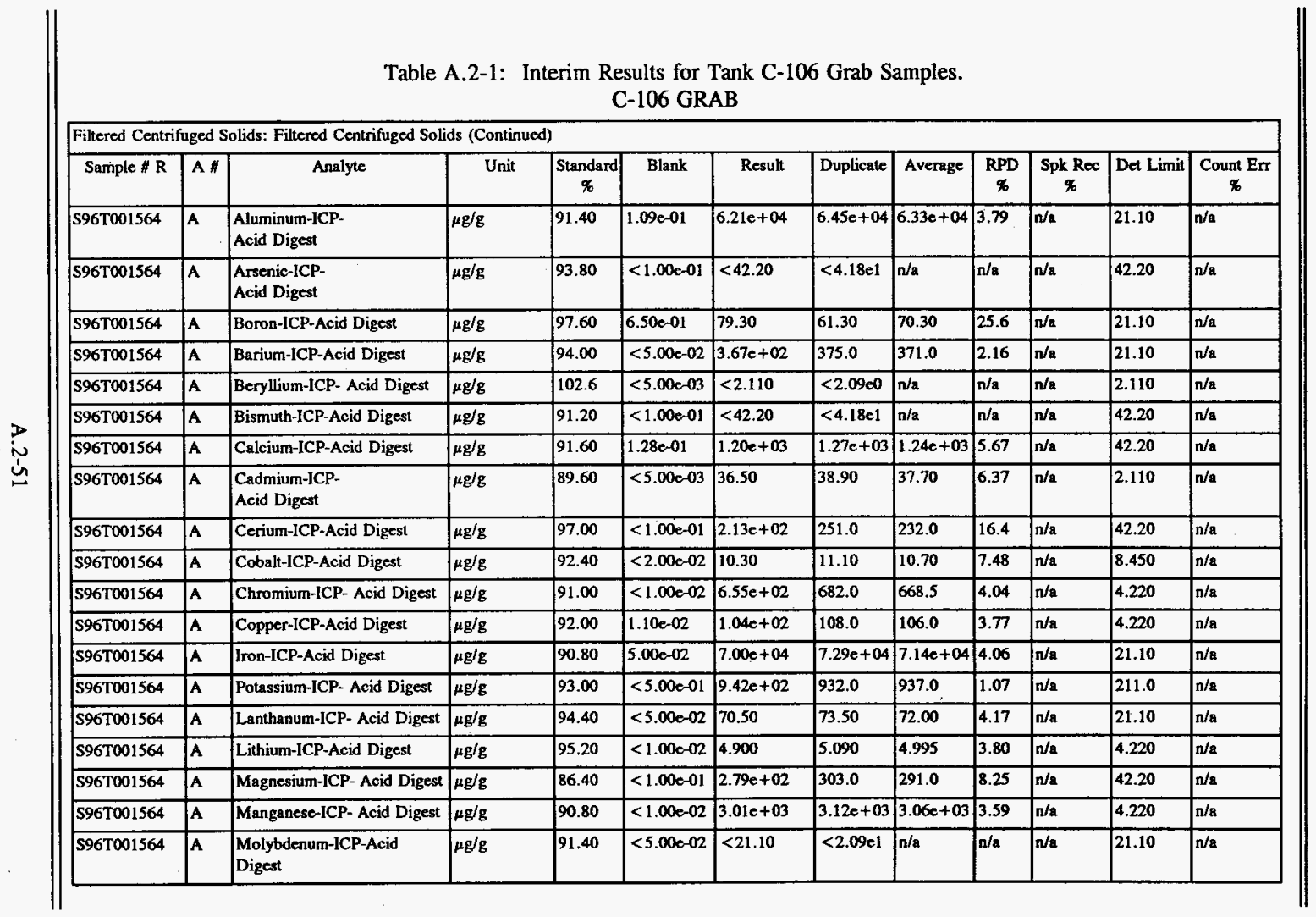


Table A.2-1: Interim Results for Tank C-106 Grab Samples.

C-106 GRAB

\begin{tabular}{|c|c|c|c|c|c|c|c|c|c|c|c|c|}
\hline \multicolumn{13}{|c|}{ Filtered Centrifuged Solids: Filtered Centrifuged Solids (Continucd) } \\
\hline Sample \# R & A \# & Analyte & Unit & $\begin{array}{c}\text { Standard } \\
\%\end{array}$ & Blank & Result & Duplicate & Average & $\begin{array}{c}\text { RPD } \\
\%\end{array}$ & $\begin{array}{c}\text { Spk Rec } \\
\%\end{array}$ & Det Limit & $\begin{array}{c}\text { Count Err } \\
\%\end{array}$ \\
\hline S96T001564 & A & Sodium-ICP-Acid Digest & $\mu \mathrm{g} / \mathrm{g}$ & 103.6 & $8.77 e-01$ & $1.41 e+05$ & $1.35 c+05$ & $1.38 c+05$ & 4.35 & $n / \mathbf{a}$ & 42.20 & $\mathrm{n} / \mathbf{4}$ \\
\hline S96T001564 & A & Neodymium-ICP-Acid Digest & $\mu \mathrm{g} / \mathrm{g}$ & 93.80 & $<1.00<-01$ & $1.74 c+02$ & 187.0 & 180.5 & 7.20 & $n / \mathbf{a}$ & 42.20 & $\mathrm{n} / \mathrm{a}$ \\
\hline S96T001564 & A & Nickel-ICP-Acid Digest & $\mu \mathrm{g} / \mathrm{g}$ & 91.80 & $<2.00<-02$ & $7.08 e+02$ & 740.0 & 724.0 & 4.42 & $n / a$ & 8.450 & $n / a$ \\
\hline S96T001564 & A & Phosphorus-ICP-Acid Digest & $\mu \mathrm{g} / \mathrm{g}$ & 96.80 & $<2.00$ e- 01 & $2.71 e+03$ & $2.74 e+03$ & $2.72 e+03$ & 1.10 & $n / a$ & 84.50 & $n / a$ \\
\hline $596 T 001564$ & A & Lead-ICP-Acid Digest & $\mu \mathrm{g} / \mathrm{g}$ & 86.80 & $<1.000-01$ & $2.81 e+03$ & $2.85 e+03$ & $2.83 e+03$ & 1.41 & $n / a$ & 42.20 & $\mathrm{n} / \mathrm{a}$ \\
\hline S96T001564 & A & Sulfur-ICP-Acid Digest & $\mu \mathrm{g} / \mathrm{g}$ & 90.20 & $<1.00 e-01$ & $1.67 e+03$ & $1.51 \mathrm{e}+03$ & $1.59 e+03$ & 10.1 & $n / a$ & 42.20 & $n / a$ \\
\hline S96T001564 & A & Antimony-ICP- Acid Digest & $\mu \mathrm{g} / \mathrm{g}$ & 93.40 & $<6.00 \mathrm{e}-02$ & $<25.30$ & $<2.51 \mathrm{el}$ & $\mathbf{n} / \mathbf{a}$ & $n / a$ & $n / a$ & $25: 30$ & $\mathbf{n} / \mathbf{a}$ \\
\hline \$96T001564 & A & Selenium-ICP- Acid Digest & $\mu \mathrm{g} / \mathrm{g}$ & 88.60 & $<1.00 e-01$ & $<42.20$ & $<4.18 \mathrm{el}$ & $n / \mathbf{a}$ & $n / a$ & $n / \mathbf{a}$ & 42.20 & $n / a$ \\
\hline S96T001564 & A & Silicon-ICP-Acid Digest & $\mu \mathrm{g} / \mathrm{g}$ & 125.0 & $7.70 \mathrm{e}-01$ & $3.55 e+04$ & $2.95 \mathrm{e}+04$ & $3.25 e+04$ & 18.5 & $\mathrm{n} / \mathrm{a}$ & 21.10 & $n / a$ \\
\hline S96T001564 & A & Samarium-ICP- Acid Digest & $\mu \mathrm{g} / \mathrm{g}$ & 92.60 & $<1.00 \mathrm{e}-01$ & $<42.20$ & $<4.18 \mathrm{el}$ & $n / a$ & $n / n$ & $n / a$ & 42.20 & $\mathrm{n} / \mathrm{a}$ \\
\hline S96T001564 & $A$ & Strontium-ICP-Acid Digest & $\mu \mathrm{g} / \mathrm{g}$ & 92.40 & $<1.00 e-02$ & 23.50 & 24.60 & 24.05 & 4.57 & $n / a$ & 4.220 & $n / a$ \\
\hline S96T001564 & A & Titanium-ICP- Acid Digest & $\mu \mathrm{g} / \mathrm{g}$ & 86.20 & $<1.00 \mathrm{e}-02$ & $1.15 e+02$ & 121.0 & 118.0 & 5.08 & $n / \mathrm{a}$ & 4.220 & $n / a$ \\
\hline S96T001564 & A & Thallium-ICP- Acid Digest & $\mu \mathrm{g} / \mathrm{g}$ & 86.00 & $<2.00<-01$ & $<84.50$ & $<8.36 \mathrm{el}$ & $n / a$ & $n / a$ & $n / a$ & 84.50 & $\mathbf{n} / \mathbf{a}$ \\
\hline S96T001564 & A & Uranium-ICP-Acid Digest & $\mu \mathrm{g} / \mathrm{g}$ & 91.20 & $<5.00 \mathrm{e}-01$ & $1.06 c+03$ & 927.0 & 993.5 & 13.4 & $n / a$ & 211.0 & $n / a$ \\
\hline S96T001564 & A & Vanadium-ICP- Acid Digest & $\mu \mathrm{g} / \mathrm{g}$ & 111.0 & $<5.00 \mathrm{e}-02$ & $<21.10$ & $<2.09 \mathrm{el}$ & $\mathrm{n} / \mathrm{a}$ & $n / a$ & $n / a$ & 21.10 & $\mathrm{n} / \mathrm{a}$ \\
\hline S96T001564 & A & Zinc-ICP-Acid Digest & $\mu \mathrm{g} / \mathrm{g}$ & 87.40 & $1.10 \mathrm{e}-02$ & 53.50 & 58.00 & 55.75 & 8.07 & $n / a$ & 4.220 & $n / a$ \\
\hline S96T001564 & A & Zirconium-ICP- Acid Digest & $\mu \mathrm{g} / \mathrm{g}$ & 99.20 & $<1.00 e-02$ & $4.52 c+02$ & $1.10 e+03$ & 776.0 & 83.5 & $\pi / a$ & 4.220 & $\mathbf{n} / \mathbf{a}$ \\
\hline$\$ 96 T 001565$ & w & $\begin{array}{l}\text { Fluoride-IC- } \\
\text { Dionex } 4000 \mathrm{i} / 4500\end{array}$ & $\mu \mathrm{g} / \mathrm{g}$ & 95.42 & $<1.30<-02$ & $<1.06 e+04$ & $<1.0904$ & $n / a$ & $n / a$ & 96.44 & $1.06 \mathrm{e}+04$ & $\mathrm{n} / \mathbf{a}$ \\
\hline S96T001565 & $\mathbf{w}$ & $\begin{array}{l}\text { Chloride-IC- } \\
\text { Dionex } 4000 \mathrm{i} / 4500\end{array}$ & $\mu g / g$ & 91.39 & $<1.700-02$ & $<1.38 e+04$ & $<1.43 e 4$ & $n / a$ & $n / a$ & 93.80 & $1.38 e+04$ & $n / \mathbf{a}$ \\
\hline S96T001565 & $\mathbf{W}$ & Nitrite-IC-Dionex $4000 \mathrm{i} / 4500$ & $\mu \mathrm{g} / \mathrm{g}$ & 93.80 & $<1.07 e-01$ & $<8.71 e+04$ & $<9.00<4$ & $n / a$ & $n / a$ & 97.26 & $8.71 e+04$ & $n / a$ \\
\hline
\end{tabular}


Table A.2-1: Interim Results for Tank C-106 Grab Samples.

C-106 GRAB

Fittered Centrifuged Solids: Filtered Centrifuged Solids (Continued)

\begin{tabular}{|c|c|c|c|c|c|c|c|c|c|c|c|c|}
\hline Sample \# $\mathrm{R}$ & $A \#$ & Analyte & Unit & $\begin{array}{c}\text { Standard } \\
\%\end{array}$ & Blank & Result & Duplicate & Average & $\begin{array}{c}\text { RPD } \\
\%\end{array}$ & $\begin{array}{c}\text { Spk Rec } \\
\%\end{array}$ & Det Limit & $\begin{array}{c}\text { Count Err } \\
\%\end{array}$ \\
\hline S96T001565 & w & $\begin{array}{l}\text { Nitrate by IC-Dionex } \\
4000 \text { i/4500 }\end{array}$ & $\mu g / \mathrm{g}$ & 93.81 & $<1.40 c-01$ & $2.90 \mathrm{e}+07$ & $1.80 c+07$ & $2.35 \mathrm{e}+07$ & 46.8 & 97.07 & $1.14 e+05$ & $n / \mathbf{a}$ \\
\hline S96T001565 & w & $\begin{array}{l}\text { Phosphate-IC- Dionex } \\
4000 \mathrm{i} / 4500\end{array}$ & $\mu g / g$ & 95.79 & $<1.19 \mathrm{e}-01$ & $<9.68 e+04$ & $<1.00 \mathrm{e}$ & $n / \mathbf{a}$ & $n / 2$ & 97.99 & $9.68 e+04$ & $n / a$ \\
\hline S96T001565 & $\mathbf{W}$ & $\begin{array}{l}\text { Sulfate by IC-Dionex } \\
4000 / 4500\end{array}$ & $\mu \mathrm{g} / \mathrm{g}$ & 95.09 & $<1.36 e-01$ & $<1.11 \mathrm{e}+05$ & $<1.14 \mathrm{es}$ & $n / \mathbf{a}$ & $n / \mathbf{a}$ & 97.62 & $1.11 e+05$ & $\mathrm{n} / \mathbf{a}$ \\
\hline S96T001565 & w & Oxalate by IC-Dionex $4000 \mathrm{i}$ & $\mu \mathrm{g} / \mathrm{g}$ & 97.09 & $<1.05 \mathrm{e}-01$ & $<4.38 \mathrm{e}+04$ & $9.23 e+04$ & $n / a$ & $\mathbf{n} / \mathbf{a}$ & 98.64 & $4.38 \mathrm{e}+04$ & $n / a$ \\
\hline \multicolumn{13}{|c|}{ Interstitial Liquid: Interstitial Liquid } \\
\hline S96T001566 & & DSC Exotherm using Mettler & Joules/g & 93.85 & $n / a$ & $1.19 e+02$ & 96.80 & 107.8 & 20.5 & $n / a$ & $n / a$ & $\pi / \mathbf{a}$ \\
\hline S96T001566 & & $\begin{array}{l}\text { DSC Exotherm Dry } \\
\text { Calculated. }\end{array}$ & Joules/g Dry & $\mathrm{n} / \mathbf{a}$ & n/a & $4.90 e+02$ & 399.3 & 444.9 & 20.5 & $n / a$ & $\overline{n / a}$ & $n / a$ \\
\hline S96T001566 & & $\begin{array}{l}\text { \% Water by TGA using } \\
\text { Mertler }\end{array}$ & $\%$ & 101.2 & $\mathrm{n} / \mathrm{a}$ & 74.92 & 76.60 & 75.76 & 2.22 & $n / \mathbf{a}$ & $\mathrm{n} / \mathrm{a}$ & $\mathrm{n} / \mathrm{a}$ \\
\hline S96T001566 & & $\begin{array}{l}\text { TOC by Persulfate/ } \\
\text { Coulometry }\end{array}$ & $\mu \mathrm{g} / \mathrm{mL}$ & 93.36 & 6.500 & $1.86 e+03$ & $1.83 e+03$ & $1.84 c+03$ & 1.63 & $n / \mathbf{a}$ & 40.00 & $n / a$ \\
\hline S96T001566 & & Strontium-89/90 High Level & $\mu \mathrm{Ci} / \mathrm{mL}$ & $n / a$ & $n / a$ & $6.39 e-02$ & $8.86 \mathrm{e}-02$ & $7.62 e-02$ & 32.4 & $n / a$ & $2.40 c-02$ & $3.65 \mathrm{E}+01$ \\
\hline S96T001566 & D & Silver-ICP-Acid Dil. & $\mu \mathrm{g} / \mathrm{mL}$ & 97.40 & $<1.00=-02$ & 8.510 & 9.270 & 8.890 & 8.55 & 92.20 & 4.010 & $\mathrm{n} / \mathrm{a}$ \\
\hline S96T001566 & $D$ & Aluminum-ICP-Acid Dil. & $\mu \mathrm{g} / \mathrm{mL}$ & 96.20 & $<5.00 \mathrm{e}-02$ & 48.10 & 66.90 & 57.50 & 32.7 & 90.00 & 20.10 & $n / a$ \\
\hline S96T001566 & D & Arsenic-ICP-Acid Dil. & $\mu \mathrm{g} / \mathrm{mL}$ & 100.4 & $<1.00 c-01$ & $<40.10$ & $<4.01 \mathrm{el}$ & $\mathrm{n} / \mathbf{a}$ & $n / a$ & 106.2 & 40.10 & $n / a$ \\
\hline S96T001566 & D & Boron-ICP-Acid Dil. & $\mu \mathrm{g} / \mathrm{mL}$ & 101.0 & $<5.00 c-02$ & 32.10 & 32.40 & 32.25 & 0.93 & 98.20 & 20.10 & $n / a$ \\
\hline S96T001566 & D & Barium-ICP-Acid Dil. & $\mu \mathrm{g} / \mathrm{mL}$ & 97.60 & $<5.00 e-02$ & $<20.10$ & $<2.01 \mathrm{el}$ & $\pi / a$ & $n / 2$ & 100.0 & 20.10 & $n / 2$ \\
\hline S96T001566 & D & Beryllium-ICP- Acid Dil. & $\mu \mathrm{g} / \mathrm{mL}$ & 102.6 & $<5.00 \mathrm{e}-03$ & $<2.000$ & $<2.0000$ & $n / \mathbf{a}$ & $n / a$ & 102.5 & 2.000 & $n / \mathbf{a}$ \\
\hline S96T001566 & D & Bismuth-ICP-Acid Dil. & $\mu \mathrm{g}^{\prime} / \mathrm{mL}$ & 98.60 & $<1.00 e-01$ & $<40.10$ & $<4.01 \mathrm{el}$ & $n / \mathbf{n}$ & $n / \mathbf{a}$ & 90.00 & 40.10 & $n / \mathbf{a}$ \\
\hline
\end{tabular}




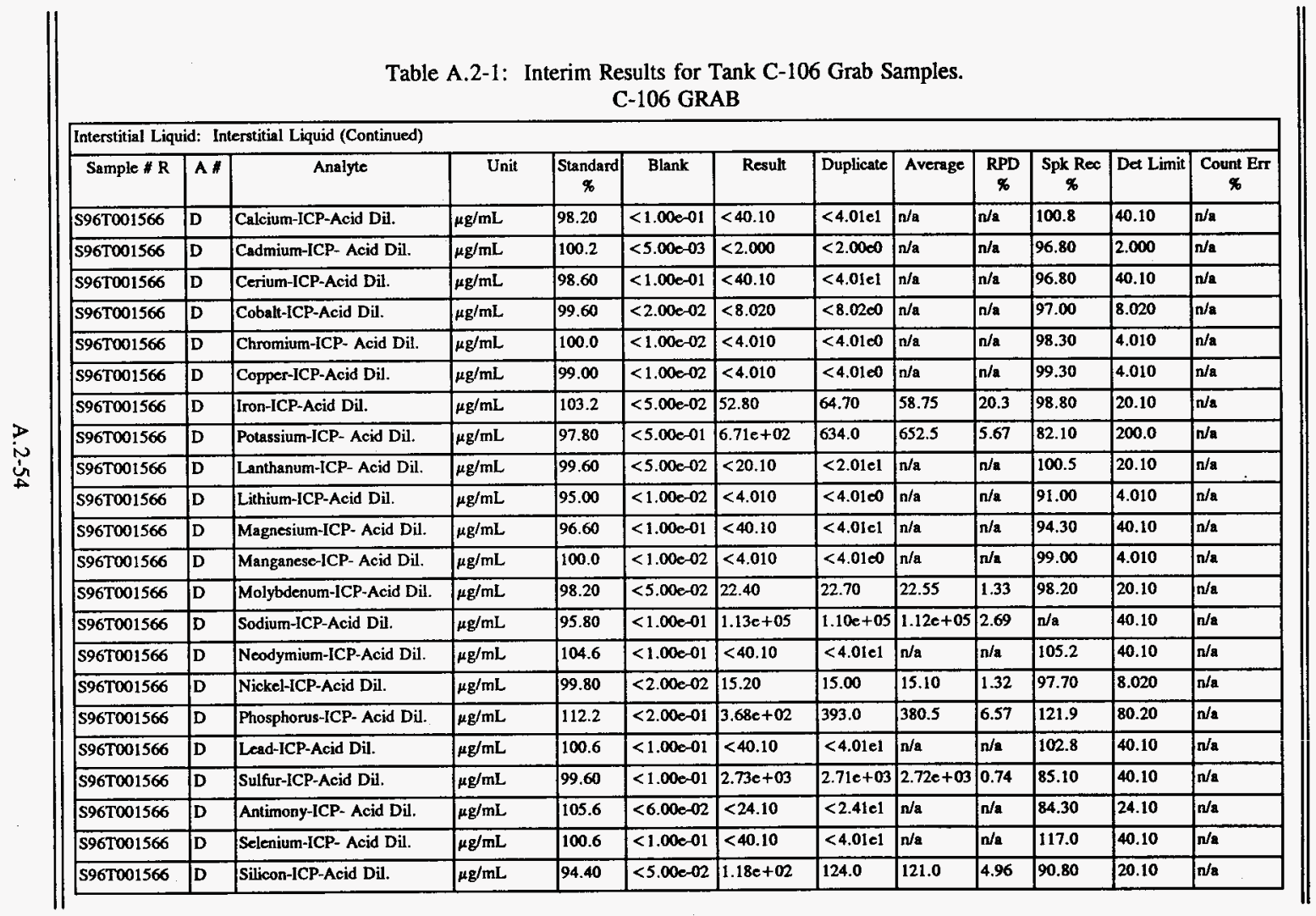


Table A.2-1: Interim Results for Tank C-106 Grab Samples.

C-106 GRAB

\begin{tabular}{|c|c|c|c|c|c|c|c|c|c|c|c|c|}
\hline \multicolumn{13}{|c|}{ Interstitial Liquid: Interstitial Liquid (Continued) } \\
\hline Sample \# R & $A \#$ & Analyte & Unit & $\begin{array}{c}\text { Standard } \\
\%\end{array}$ & Blank & Result & Duplicate & Average & $\begin{array}{c}\text { RPD } \\
\varnothing\end{array}$ & $\begin{array}{c}\text { Spk Roc } \\
\varnothing\end{array}$ & Det Limit & $\begin{array}{c}\text { Count Err } \\
\varnothing\end{array}$ \\
\hline S96T001566 & D & Samarium-ICP- Acid Dil. & $\mu \mathrm{g} / \mathrm{mL}$ & 98.80 & $<1.00 \mathrm{e}-01$ & $<40.10$ & $<4.01 \mathrm{el}$ & $n / a$ & $n / a$ & 102.8 & 40.10 & $\mathbf{n} / \mathbf{a}$ \\
\hline S96T001566 & D & Strontium-ICP- Acid Dil. & $\mu \mathrm{g} / \mathrm{mL}$ & 97.80 & $<1.00 \mathrm{e}-02$ & $<4.010$ & $<4.01 \mathrm{e} 0$ & $\mathrm{n} / \mathrm{a}$ & $n / \mathbf{a}$ & 100.3 & 4.010 & $n / \mathbf{a}$ \\
\hline S96T001566 & $\mathbf{D}$ & Titanium-ICP- Acid Dil. & $\mu \mathrm{g} / \mathrm{mL}$ & 95.60 & $<1.00 \mathrm{e}-02$ & $<4.010$ & $<4.0100$ & $\mathbf{n} / \mathbf{a}$ & $n / \mathbf{a}$ & 96.80 & 4.010 & $\mathbf{n} / \mathbf{a}$ \\
\hline S96T001566 & D & Thallium-ICP-Acid Dil. & $\mu \mathrm{g} / \mathrm{mL}$ & 94.60 & $<2.00 \mathrm{e}-01$ & $<80.20$ & $<8.02 \mathrm{el}$ & $n / a$ & $\mathbf{n} / \mathbf{a}$ & 86.50 & 80.20 & $\mathbf{n} / \mathbf{a}$ \\
\hline S96T001566 & D & Uranium-ICP-Acid Dil. & $\mu \mathrm{g} / \mathrm{mL}$ & 95.60 & $<5.00 \mathrm{e}-01$ & $1.87 e+03$ & $1.83 \mathrm{e}+03$ & $1.85 e+03$ & 2.16 & 99.85 & 200.0 & $\mathbf{n} / \mathbf{a}$ \\
\hline S96T001566 & $\mathrm{D}$ & Varadium-ICP-Acid Dil. & $\mu \mathrm{g} / \mathrm{mL}$ & 101.4 & $<5.00=-02$ & $<20.10$ & $<2.01 \mathrm{el}$ & $n / a$ & $n / a$ & 100.0 & 20.10 & $n / a$ \\
\hline $596 \mathrm{~T} 001566$ & D & Zinc-ICP-Acid Dil. & $\mu \mathrm{g} / \mathrm{mL}$ & 100.8 & $<1.00=-02$ & $<4.010$ & $<4.0100$ & $n / a$ & $\mathrm{n} / \mathbf{a}$ & 96.80 & 4.010 & $n / a$ \\
\hline S96T001566 & D & Zirconium-ICP- Acid Dil. & $\mu \mathrm{g} / \mathrm{mL}$ & 98.80 & $<1.00 \mathrm{c}-02$ & $3.79 c+02$ & 375.0 & 377.0 & 1.06 & 99.90 & 4.010 & $n / a$ \\
\hline S96T001566 & & Cobalt- 60 by GEA & $\mu \mathrm{Ci} / \mathrm{mL}$ & 98.44 & $<2.89 \mathrm{e}-03$ & $<6.19 \mathrm{e}-03$ & $<7.13 \mathrm{e}-3$ & $n / a$ & $\mathrm{n} / \mathbf{a}$ & $n / a$ & $6.00=-03$ & $n / a$ \\
\hline S96T001566 & & Cesium- 137 by GEA & $\mu \mathrm{Ci} / \mathrm{mL}$ & 96.31 & $<8.70 \mathrm{e}-03$ & $1.35 e+02$ & 170.0 & 152.5 & 23.0 & $n / \mathbf{n}$ & $n / \mathbf{a}$ & 0.210 \\
\hline \multicolumn{13}{|c|}{ Potential Organic Layer: Potential Organic Layer } \\
\hline S96T001553 & & DSC Exotherm using Mettler & Joukes/g & 113.9 & $n / a$ & $2.08 c+02$ & 167.9 & 188.0 & 21.4 & $n / a$ & $n / a$ & n/a \\
\hline S96T001553 & & $\begin{array}{l}\text { DSC Exotherm Dry } \\
\text { Calculated }\end{array}$ & Joules/g Dry & $n / a$ & $n / a$ & $7.54 e+02$ & 608.3 & 681.1 & 21.4 & $n / a$ & $n / a$ & $n / a$ \\
\hline S96T001553 & & $\begin{array}{l}\text { \% Water by TGA using } \\
\text { Mettler }\end{array}$ & $\%$ & 103.7 & $n / a$ & 72.40 & 30.11 & 51.26 & 82.5 & $n / a$ & $n / a$ & $n / a$ \\
\hline \multicolumn{13}{|c|}{ Sludge (from Liquid Grab Sample): Sludge (from Liquid Grab Sample) } \\
\hline$\$ 967003181$ & $w$ & $\begin{array}{l}\text { Fluoride-IC- Dionex } \\
4000 \mathrm{i} / 4500\end{array}$ & $\mu g / g$ & 104.2 & $<1.30 \mathrm{e}-02$ & $4.02 e+02$ & 119.0 & 260.3 & 109 & 97.63 & 52.21 & $n / \mathbf{a}$ \\
\hline S96T003181 & $\mathbf{W}$ & $\begin{array}{l}\text { Chloride-IC- Dionex } \\
4000 \mathrm{i} / 4500\end{array}$ & $\mu \mathrm{g} / \mathrm{g}$ & 96.58 & $<1.70 \mathrm{e}-02$ & $1.56 e+02$ & 197.0 & 176.4 & 23.2 & 149.4 & 68.28 & $n / a$ \\
\hline S96T003181 & $w$ & Nitrite-IC-Dionex $4000 \mathrm{i} / 4500$ & $\mu g / g$ & 93.91 & $<1.070-01$ & $1.16 e+04$ & $1.09 e+04$ & $1.13 e+04$ & 6.22 & 93.54 & 429.8 & $\mathrm{n} / \mathrm{a}$ \\
\hline S96T003181 & w & $\begin{array}{l}\text { Nitrate by IC-Dionex } \\
4000 \mathrm{i} / 4500\end{array}$ & $\mu g / g$ & 102.8 & 5.910 & $9.89 e+02$ & $1.94 e+03$ & $1.46 e+03$ & 64.9 & 96.09 & 561.9 & $n / a$ \\
\hline
\end{tabular}


Table A.2-1: Interim Results for Tank C-106 Grab Samples.

\section{C-106 GRAB}

Sludge (from Liquid Grab Sample): Sludge (from Liquid Grab Sample) (Continued)

\begin{tabular}{|c|c|c|c|c|c|c|c|c|c|c|c|c|}
\hline Sample \# $\mathbf{R}$ & $A$ & Analyte & Unit & $\begin{array}{c}\text { Standard } \\
\%\end{array}$ & Blank & Result & Duplicate & Average & $\begin{array}{c}\text { RPD } \\
\%\end{array}$ & $\begin{array}{c}\text { Spk Rec } \\
\%\end{array}$ & Det Limit & $\begin{array}{c}\text { Count Err } \\
\%\end{array}$ \\
\hline S96T003181 & w & $\begin{array}{l}\text { Phosphate-IC- Dionex } \\
4000 \text { i/4500 }\end{array}$ & $\mu \mathrm{g} / \mathrm{g}$ & 105.3 & $<1.190-01$ & $9.24 c+02$ & $1.08 \mathrm{c}+03$ & $1.00 c+03$ & 15.6 & 97.44 & 477.5 & $n / a$ \\
\hline S96T003181 & W & $\begin{array}{l}\text { Sulfate by IC- Dionex } \\
4000 \mathrm{i} / 4500\end{array}$ & $\mu \mathrm{g} / \mathrm{g}$ & 105.7 & $<1.36 \mathrm{e}-01$ & $3.52 c+03$ & $3.12 e+03$ & $3.32 e+03$ & 12.0 & 100.6 & 545.8 & $\mathrm{n} / \mathbf{a}$ \\
\hline S96T003181 & $w$ & Oxalate by IC- Dionex $4000 \mathrm{i}$ & $\mu \mathrm{g} / \mathrm{g}$ & 105.3 & $<1.05 \mathrm{e}-01$ & $2.50 c+04$ & $8.25 \mathrm{e}+04$ & $5.37 e+04$ & 107 & 99.80 & 421.7 & $n / a$ \\
\hline \multicolumn{13}{|c|}{ SEGMENT PORTION: Compatibility Study Mixture } \\
\hline S96T002825 & & $\begin{array}{l}\text { DSC Exotherm on Perkin } \\
\text { Elmer }\end{array}$ & Joules/g & 100.6 & $\mathrm{n} / \mathrm{a}$ & $0.00 e+\infty$ & $0.00 \mathrm{e}+\infty$ & $0.00 e+00$ & 0.00 & $n / a$ & $\mathbf{n} / \mathbf{a}$ & $\mathbf{n} / \mathbf{a}$ \\
\hline $596 \mathrm{~T} 002825$ & & pH Direct & pH & $n / a$ & $n / a$ & 11.12 & $n / a$ & $n / a$ & $\mathbf{n} / \mathbf{a}$ & $n / a$ & $1.00=-02$ & $\mathbf{n} / \mathbf{a}$ \\
\hline$\$ 96 \mathrm{~T} 002825$ & & $\begin{array}{l}\text { \% Water by TGA on Perkin } \\
\text { Elmer }\end{array}$ & $\%$ & 97.87 & $\mathrm{n} / \mathrm{a}$ & 95.78 & 90.16 & 92.97 & 6.04 & $n / a$ & $\mathbf{n} / \mathbf{a}$ & $\mathrm{n} / \mathrm{a}$ \\
\hline S96T002827 & & Bulk Density of Sample & $g / m L$ & $\mathbf{n} / \mathbf{a}$ & $n / a$ & & $n / a$ & $n / a$ & $\mathbf{n} / \mathbf{a}$ & $n / a$ & $5.00 \mathrm{e}-01$ & $n / a$ \\
\hline S96T002827 & & $\begin{array}{l}\text { \% Water by TGA using } \\
\text { Mettler }\end{array}$ & $\%$ & 103.7 & $n / a$ & 95.08 & 93.40 & 94.24 & 1.78 & $n / a$ & $n / a$ & $\mathbf{n} / \mathbf{a}$ \\
\hline S96T002829 & & DSC Exotherm using Mettler & Joules/g & 111.8 & $n / x$ & $0.00 c+00$ & 580.2 & 290.1 & 200 & $n / a$ & $n / a$ & $n / a$ \\
\hline S96T0028291 & & DSC Exotherm using Mettler & Joules/g & 114.2 & $n / a$ & $0.00 e+00$ & 77.80 & 38.90 & 200 & $n / \mathbf{a}$ & $n / a$ & $n / a$ \\
\hline S96T002829 & & pH Direct & $\mathrm{pH}$ & $n / a$ & $n / a$ & 11.80 & 11.79 & 11.79 & 0.08 & $n / a$ & $1.00 \mathrm{e}-02$ & $n / a$ \\
\hline S96T002829 & & $\begin{array}{l}\text { \% Water by TGA using } \\
\text { Meuler }\end{array}$ & $\%$ & 99.54 & $n / a$ & 95.69 & 96.02 & 95.85 & 0.34 & $n / a$ & $n / a$ & $n / a$ \\
\hline S96T002831 & & Bulk Density of Sample & $\mathrm{g} / \mathrm{mL}$ & $n / a$ & $\mathbf{n} / \mathbf{a}$ & & $n / a$ & $n / a$ & $n / a$ & $n / \mathbf{n}$ & $5.00-01$ & $n / a$ \\
\hline S96T002831 & & $\begin{array}{l}\text { \% Water by TGA on Perkin } \\
\text { Elmer }\end{array}$ & $\%$ & 99.61 & $n / a$ & 83.85 & 85.53 & 84.69 & 1.98 & $\mathbf{n} / \mathbf{a}$ & $n / a$ & $n / a$ \\
\hline
\end{tabular}




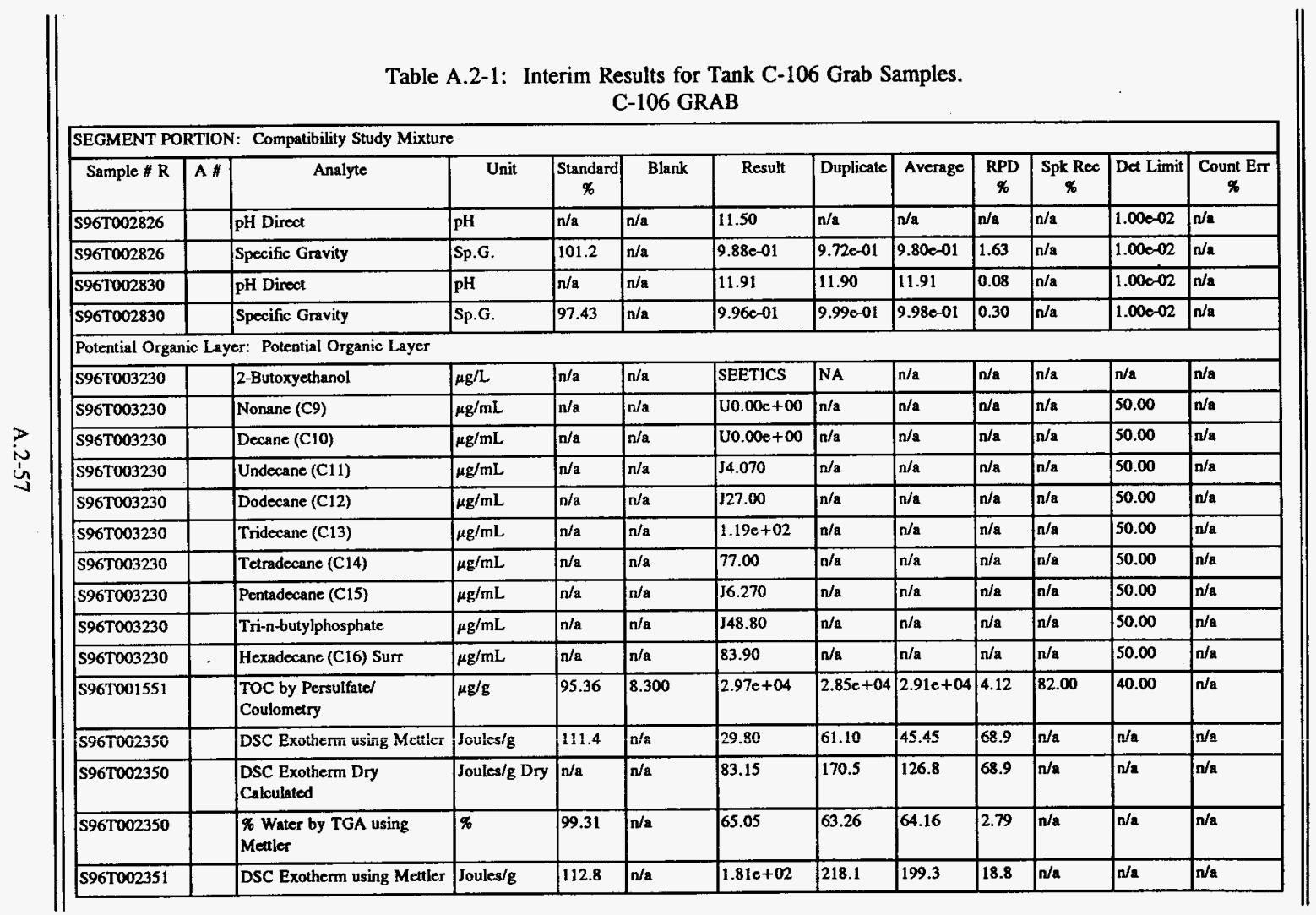


Table A.2-1: Interim Results for Tank C-106 Grab Samples.

C-106 GRAB

\begin{tabular}{|c|c|c|c|c|c|c|c|c|c|c|c|c|}
\hline \multicolumn{13}{|c|}{ Potential Organic Layer: Potential Organic Layer (Continued) } \\
\hline Sample \# $\mathbf{R}$ & $A$ & Analyte & Unit & $\begin{array}{c}\text { Standard } \\
\%\end{array}$ & Blank & Result & Duplicate & Average & $\begin{array}{c}\text { RPD } \\
\%\end{array}$ & $\begin{array}{c}\text { Spk Rec } \\
\varnothing\end{array}$ & Det Limit & $\underset{\%}{\text { Count Err }}$ \\
\hline S96T002351 & & $\begin{array}{l}\text { DSC Exotherm Dry } \\
\text { Calculated }\end{array}$ & Joules/g Dry & $n / a$ & $\mathrm{n} / \mathrm{a}$ & $4.04 e+02$ & 487.9 & 445.9 & 18.8 & $n / a$ & $n / a$ & $\mathbf{n} / \mathbf{a}$ \\
\hline S96T002351 & & $\begin{array}{l}\% \text { Water by TGA on Perkin } \\
\text { Elmer }\end{array}$ & $\%$ & 97.43 & $\mathrm{n} / \mathrm{a}$ & 56.03 & 54.56 & 55.30 & 2.66 & $n / a$ & $n / a$ & $n / \mathbf{a}$ \\
\hline \multicolumn{13}{|c|}{ Supernate: Supernate } \\
\hline S96T001546 & $\mathrm{D}$ & Silver-ICP-Acid Dil. & $\mu \mathrm{g} / \mathrm{mL}$ & 97.80 & $<1.00 \mathrm{e}-02$ & $<4.010$ & $<4.0100$ & $n / a$ & $n / a$ & 90.00 & 4.010 & $n / a$ \\
\hline S96T001546 & D & Aluminum-ICP- Aid Dil. & $\mu \mathrm{g} / \mathrm{mL}$ & 100.0 & $<5.00 \mathrm{e}-02$ & $<20.10$ & $<2.01 \mathrm{el}$ & $n / a$ & $\mathbf{n} / \mathbf{a}$ & 96.30 & 20.10 & $\mathrm{n} / \mathrm{a}$ \\
\hline S96T001546 & D & Arsenic-ICP-Acid Dil. & $\mu \mathrm{g} / \mathrm{mL}$ & 103.0 & $<1.00 \mathrm{e}-01$ & $<40.10$ & $<4.01 \mathrm{el}$ & $n / a$ & $\mathbf{n} / \mathbf{a}$ & 103.3 & 40.10 & $n / a$ \\
\hline S96T001546 & $D$ & Boron-ICP-Acid Dil. & $\mu \mathrm{g} / \mathrm{mL}$ & 103.2 & $<5.00 \mathrm{e}-02$ & $<20.10$ & $<2.01 \mathrm{el}$ & $n / a$ & $\mathbf{a} / \mathbf{a}$ & 101.0 & 20.10 & $n / a$ \\
\hline S96T001546 & D & Barium-ICP-Acid Dil. & $\mu \mathrm{g} / \mathrm{mL}$ & 104.0 & $<5.00 e-02$ & $<20.10$ & $<2.01 \mathrm{el}$ & $\mathrm{n} / \mathrm{a}$ & $n / a$ & 102.8 & 20.10 & $n / a$ \\
\hline S96T001546 & D & Beryllium-ICP- Acid Dil. & $\mu \mathrm{g} / \mathrm{mL}$ & 105.6 & $<5.00 \mathrm{e}-03$ & $<2.000$ & $<2.0000$ & $\mathrm{n} / \mathrm{a}$ & $\mathrm{n} / \mathrm{a}$ & 102.5 & 2.000 & $n / \mathfrak{a}$ \\
\hline S96T001546 & D & Bismuth-ICP-Acid Dil. & $\mu \mathrm{g} / \mathrm{mL}$ & 101.4 & $<1.00 \mathrm{e}-01$ & $<40.10$ & $<4.01 \mathrm{el}$ & $n / a$ & $n / a$ & 89.50 & 40.10 & $n / a$ \\
\hline S96T001546 & $\mathrm{D}$ & Calcium-ICP-Acid Dil. & $\mu \mathrm{g} / \mathrm{mL}$ & 103.2 & $<1.00 \mathrm{e}-01$ & $<40.10$ & $<4.01 \mathrm{el}$ & $n / a$ & $n / a$ & 104.2 & 40.10 & $n / a$ \\
\hline S96T001546 & $\mathrm{D}$ & Cadmium-ICP- Acid Dil. & $\mu \mathrm{g} / \mathrm{mL}$ & 99.60 & $<5.00=-03$ & $<2.000$ & $<2.00<0$ & $\mathrm{n} / \mathrm{a}$ & $n / a$ & 94.80 & 2.000 & $n / a$ \\
\hline S96T001546 & D & Cerium-ICP-Acid Dil. & $\mu \mathrm{g} / \mathrm{mL}$ & 105.0 & $<1.00 \mathrm{e}-01$ & $<40.10$ & $<4.01 \mathrm{el}$ & $\mathrm{n} / \mathrm{a}$ & $n / a$ & 100.8 & 40.10 & $n / a$ \\
\hline S96T001546 & D & Cobalt-ICP-Acid Dil. & $\mu \mathrm{g} / \mathrm{mL}$ & 100.0 & $<2.00 \mathrm{e}-02$ & $<8.020$ & $<8.0200$ & $n / a$ & $n / a$ & 95.00 & 8.020 & $n / a$ \\
\hline S96T001546 & D & Chromium-ICP- Acid Dil. & $\mu \mathrm{g} / \mathrm{mL}$ & 98.80 & $<1.00 \mathrm{e}-02$ & $<4.010$ & $<4.01 \mathrm{c0}$ & $n / a$ & $n / a$ & 94.80 & 4.010 & $n / a$ \\
\hline S96T001546 & $\mathrm{D}$ & Copper-ICP-Acid Dil. & $\mu \mathrm{g} / \mathrm{mL}$ & 105.0 & $<1.00 e-02$ & $<4.010$ & $<4.0100$ & $n / a$ & $n / a$ & 102.3 & 4.010 & $n / a$ \\
\hline S96T001546 & D & Iron-ICP-Acid Dil. & $\mu \mathrm{g} / \mathrm{mL}$ & 102.0 & $<5.00 \mathrm{e}-02$ & $<20.10$ & $<2.01 \mathrm{e} 1$ & $\mathrm{n} / \mathrm{a}$ & $n / a$ & 100.0 & 20.10 & $n / a$ \\
\hline S96T001546 & $\mathrm{D}$ & Potassium-ICP- Acid Dil. & $\mu \mathrm{g} / \mathrm{mL}$ & 101.4 & $<5.00 \mathrm{e}-01$ & $5.08 c+02$ & 496.0 & 502.0 & 2.39 & 81.20 & 200.0 & $n / a$ \\
\hline S96T001546 & $\mathrm{D}$ & Lanthanum-ICP-Acid Dil. & $\mu \mathrm{g} / \mathrm{mL}$ & 102.6 & $<5.00 e-02$ & $<20.10$ & $<2.01 \mathrm{el}$ & $n / a$ & $n / a$ & 101.5 & 20.10 & $n / a$ \\
\hline S96T001546 & D & Lithium-ICP-Acid Dil. & $\mu \mathrm{g} / \mathrm{mL}$ & 106.4 & $<1.00=-02$ & $<4.010$ & $<4.0100$ & $\mathrm{n} / \mathrm{a}$ & $n / a$ & 100.0 & 4.010 & $n / a$ \\
\hline S96T001546 & D & Magnesium-ICP-Acid Dil. & $\mu \mathrm{g} / \mathrm{mL}$ & 97.00 & $<1.00 \mathrm{e}-01$ & $<40.10$ & $<4.01 \mathrm{el}$ & $n / a$ & $n / a$ & 92.00 & 40.10 & $n / a$ \\
\hline
\end{tabular}


Table A.2-1: Interim Results for Tank C-106 Grab Samples.

C-106 GRAB

\begin{tabular}{|c|c|c|c|c|c|c|c|c|c|c|c|c|}
\hline Sample \# R & A \# & Analyte & Unit & $\begin{array}{c}\text { Standard } \\
\%\end{array}$ & Blank & Result & Duplicate & Average & $\begin{array}{c}\text { RPD } \\
\%\end{array}$ & $\begin{array}{c}\text { Spk Rec } \\
\%\end{array}$ & Det Limit & $\begin{array}{c}\text { Count Err } \\
\%\end{array}$ \\
\hline S96T001546 & D & Manganese-ICP-Acid Dil. & $\mu \mathrm{g} / \mathrm{mL}$ & 99.40 & $<1.00=-02$ & $<4.010$ & $<4.0100$ & $\mathrm{n} / \mathrm{a}$ & $n / a$ & 96.00 & 4.010 & $n / a$ \\
\hline S96T001546 & D & Molybdenum-ICP-Acid Dil. & $\mu \mathrm{g} / \mathrm{mL}$ & 100.2 & $<5.000-02$ & 21.80 & 21.80 & 21.80 & 0.00 & 95.60 & 20.10 & $n / a$ \\
\hline$\$ 96 \mathrm{~T} 001546$ & D & Sodium-ICP-Acid Dil. & $\mu \mathrm{g} / \mathrm{mL}$ & 105.0 & $<1.00 \mathrm{e}-01$ & $1.10 e+05$ & $1.06 e+05$ & $1.08 e+05$ & 3.70 & $\mathrm{n} / \mathbf{a}$ & 40.10 & $n / n$ \\
\hline S96T001546 & D & Neodymium-ICP-Acid Dil. & $\mu \mathrm{g} / \mathrm{mL}$ & 108.4 & $<1.00 c-01$ & $<40.10$ & $<4.01 \mathrm{el}$ & $\mathbf{n} / \mathbf{a}$ & $n / a$ & 109.5 & 40.10 & $n / a$ \\
\hline S96T001546 & D & Nickel-ICP-Acid Dil. & $\mu \mathrm{g} / \mathrm{mL}$ & 99.40 & $<2.00$ e-02 & 16.40 & 17.10 & 16.75 & 4.18 & 94.40 & 8.020 & $n / a$ \\
\hline $596 T 001546$ & D & Phosphorus-ICP- Acid Dil. & $\mu \mathrm{g} / \mathrm{mL}$ & 102.0 & $<2.000-01$ & $2.92 e+02$ & 299.0 & 295.5 & 2.37 & 98.10 & 80.20 & $n / a$ \\
\hline S96T001546 & D & Lead-ICP-Acid Dil. & $\mu \mathrm{g} / \mathrm{mL}$ & 99.40 & $<1.00 \mathrm{e}-01$ & $<40.10$ & $<4.01 \mathrm{e} 1$ & $n / a$ & $n / a$ & 96.30 & 40.10 & $n / \mathbf{a}$ \\
\hline S96T001546 & D & Sulfur-ICP-Acid Dil. & $\mu \mathrm{g} / \mathrm{mL}$ & 99.40 & $<1.00 e-01$ & $2.42 e+03$ & $2.35 e+03$ & $2.38 c+03$ & 2.94 & 26.40 & 40.10 & $n / a$ \\
\hline S96T001546 & D & Antimony-ICP- Acid Dil. & $\mu \mathrm{g} / \mathrm{mL}$ & 96.80 & $<6.00<-02$ & $<24.10$ & $<2.41 \mathrm{e} 1$ & $n / \mathbf{a}$ & $n / a$ & 91.50 & 24.10 & $n / a$ \\
\hline S96T001546 & $\mathbf{D}$ & Selenium-ICP- Acid Dil. & $\mu \mathrm{g} / \mathrm{mL}$ & 106.0 & $<1.00<-01$ & $<40.10$ & $<4.01 e 1$ & $n / 2$ & $n / a$ & 112.2 & 40.10 & $n / a$ \\
\hline S96T001546 & D & Silicon-ICP-Acid Dil. & $\mu \mathrm{g} / \mathrm{mL}$ & 95.60 & $<5.00 \mathrm{e}-02$ & $<20.10$ & $<2.01 \mathrm{el}$ & $n / a$ & $n / a$ & 95.00 & 20.10 & $n / a$ \\
\hline S96T001546 & D & Samarium-ICP- Acid Dil. & $\mu \mathrm{g} / \mathrm{mL}$ & 105.8 & $<1.00 \mathrm{e}-01$ & $<40.10$ & $<4.01 \mathrm{e} 1$ & $n / a$ & $n / a$ & 109.0 & 40.10 & $n / a$ \\
\hline S96T001546 & D & Strontium-ICP- Acid Dil. & $\mu \mathrm{g} / \mathrm{mL}$ & 103.4 & $<1.00 \mathrm{e}-02$ & $<4.010$ & $<4.0100$ & $n / a$ & $n / a$ & 102.3 & 4.010 & $n / a$ \\
\hline$\$ 96 \mathrm{~T} 001546$ & D & Titanium-ICP- Acid Dil. & $\mu \mathrm{g} / \mathrm{mL}$ & 99.00 & $<1.00 \mathrm{e}-02$ & $<4.010$ & $<4.01 \mathrm{eO}$ & $\mathbf{n} / \mathbf{a}$ & $n / a$ & 96.50 & 4.010 & $n / a$ \\
\hline S96T001546 & D & Thallium-ICP- Acid Dil. & $\mu \mathrm{g} / \mathrm{mL}$ & 97.20 & $<2.000-01$ & $<80.20$ & $<8.02 \mathrm{e} 1$ & $n / \mathbf{a}$ & $n / a$ & 90.80 & 80.20 & $n / a$ \\
\hline S96T001546 & D & Uranium-ICP-Acid Dil. & $\mu \mathrm{g} / \mathrm{mL}$ & 100.0 & $<5.00 e-01$ & $1.76 e+03$ & $1.79 e+03$ & $1.78 c+03$ & 1.69 & 88.70 & 200.0 & $n / a$ \\
\hline S96T001546 & D & Vanadium-ICP-Acid Dil. & $\mu \mathrm{g} / \mathrm{mL}$ & 102.0 & $<5.000-02$ & $<20.10$ & $<2.01 \mathrm{el}$ & $n / \mathbf{a}$ & $n / a$ & 98.30 & 20.10 & $n / a$ \\
\hline S96T001546 & D & Zinc-ICP-Acid Dil. & $\mu \mathrm{g} / \mathrm{mL}$ & 100.0 & $<1.00 \mathrm{e}-02$ & 4.320 & $<4.01 \mathrm{e0}$ & $n / a$ & $n / a$ & 93.20 & 4.010 & $n / a$ \\
\hline S96T001546 & D & Zirconium-ICP- Acid Dil. & $\mu \mathrm{g} / \mathrm{mL}$ & 101.4 & $<1.000-02$ & $3.81 e+02$ & 377.0 & 379.0 & 1.06 & 93.50 & 4.010 & $n / a$ \\
\hline S96T001546 & & $\begin{array}{l}\text { Fluoride-IC-Dionex } \\
4000 \mathrm{i} / 4500\end{array}$ & $\mu \mathrm{g} / \mathrm{mL}$ & 98.81 & $<1.30 c-02$ & $2.23 e+02$ & 212.0 & 217.3 & 5.06 & 125.6 & 14.44 & $\mathrm{n} / \mathrm{a}$ \\
\hline S96T001546 & & $\begin{array}{l}\text { Chloride-IC-Dionex } 4000 \mathrm{i} / 450 \\
0\end{array}$ & $\mu \mathrm{g} / \mathrm{mL}$ & 93.17 & $<1.70 \mathrm{e}-02$ & $2.97 e+02$ & 295.0 & 295.8 & 0.68 & 99.75 & 18.89 & $n / a$ \\
\hline
\end{tabular}


Table A.2-1: Interim Results for Tank C-106 Grab Samples.

C-106 GRAB

Supernate: Supernate (Continued)

\begin{tabular}{|c|c|c|c|c|c|c|c|c|c|c|c|c|}
\hline Sample \# $\mathbf{R}$ & A \# & Analyte & Unit & $\begin{array}{c}\text { Standard } \\
\%\end{array}$ & Blank & Result & Duplicate & Average & $\stackrel{\text { RPD }}{\%}$ & $\underset{\%}{\text { Spk Rec }}$ & Det Limit & $\begin{array}{c}\text { Count Err } \\
\%\end{array}$ \\
\hline S96T001546 & & Nitrite-IC-Dionex $4000 \mathrm{i} / 4500$ & $\mu \mathrm{g} / \mathrm{mL}$ & 98.61 & $<1.07 \mathrm{e}-01$ & $3.02 e+04$ & $3.04 e+04$ & $3.03 e+04$ & 0.66 & 96.88 & 118.9 & $n / \mathbf{a}$ \\
\hline S96T001546 & & Nitrate-IC-Dionex $4000 \mathrm{j} / 4500$ & $\mu \mathrm{g} / \mathrm{mL}$ & 99.67 & $2.38 \mathrm{e}-01$ & $1.00 e+03$ & $1.09 e+03$ & $1.05 e+03$ & 8.61 & 96.91 & 155.5 & $n / a$ \\
\hline S96T001546 & & $\begin{array}{l}\text { Phosphate-IC-Dionex } \\
4000 \mathrm{i} / 4500\end{array}$ & $\mu \mathrm{g} / \mathrm{mL}$ & 100.7 & $<1.19 \mathrm{e}-01$ & $5.13 e+02$ & 530.0 & 521.6 & 3.26 & 101.5 & 132.1 & $n / \mathbf{a}$ \\
\hline S96T001546 & & $\begin{array}{l}\text { Sulfate by IC-Dionex } \\
4000 \mathrm{i} / 4500\end{array}$ & $\mu \mathrm{g} / \mathrm{mL}$ & 99.53 & $<1.36 \mathrm{e}-01$ & $7.88 e+03$ & $7.90 e+03$ & $7.89 e+03$ & 0.25 & 103.8 & 151.0 & $n / \mathbf{a}$ \\
\hline S96T001546 & & Oxalate by lC-Dionex $4000^{\circ}$ & $\mu \mathrm{g} / \mathrm{mL}$ & 100.2 & $<1.05 \mathrm{e}-01$ & $3.53 e+03$ & $3.50 e+03$ & $3.52 e+03$ & 0.85 & 101.1 & 116.7 & $\mathbf{n} / \mathbf{a}$ \\
\hline
\end{tabular}


WHC-SD-WM-TI-756, Rev. 0

\begin{abstract}
APPENDIX A.3
DOSE MEASUREMENTS TAKEN DURING THE APRIL 19, 1986 CORE SAMPLING OF C-106
\end{abstract}

\title{
A.3-1
}


WHC-SD-WM-TI-756, Rev. 0

This page intentionally left blank.

A. 3-2 
WHC-SD-WM-TI-756, Rev. 0

\section{APPENDIX A.3}

\section{DOSE MEASUREMENTS TAKEN DURING THE APRUL 19, 1986 CORE SAMPLING OF C-106}

A summary of dose (mrem $/ \mathrm{hr}$ ) measurements obtained on the tank C-106 core samples taken April 19, 1986.

Table A.3-1. A Summary of Dose Measurements from April 19, 1986 Tank C-106 Core Samples. ${ }^{1}$

\begin{tabular}{|c|c|c|}
\hline Aeromiplon & 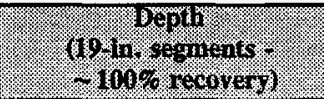 & (througl the drily \\
\hline Top liquid layer & $\begin{array}{l}\sim 8 \text { in.; estimated as } 12 \text { in. } \\
\text { supernate }\end{array}$ & Included with topmost solids \\
\hline $\begin{array}{l}\text { Topmost dark brown solids } \\
\text { (BL waste) }\end{array}$ & Next $\sim 15$ in. & 1,500 \\
\hline $\begin{array}{l}\text { Dark brown soft solids } \\
\text { (BL waste) }\end{array}$ & Next $\sim 19$ in. & 2,100 \\
\hline $\begin{array}{l}\text { Dark brown soft solids } \\
\text { (PUREX AR waste) }\end{array}$ & Next $\sim 12$ in. & 2,800 \\
\hline $\begin{array}{l}\text { Dark brown solids } \\
\text { overlaying hard solids } \\
\text { (UR/CWP1 heels) }\end{array}$ & Next $\sim 19$ in. & 2,000 \\
\hline
\end{tabular}

Note:

'Fowler (1991) 
WHC-SD-WM-TI-756, Rev. 0

This page intentionally left blank. 


\section{APPENDIX A.4}

\section{WORSE-CASE TOTAL ORGANIC CARBON MEASUREMENTS IN TANKS AY-102 AND C-106}

(Excerpted from Castaing 1995) 
WHC-SD-WM-TI-756, Rev. 0

This page intentionally left blank.

A.4-2 


\section{APPENDIX A.4}

\section{WORST-CASE TOTAL ORGANIC CARBON MEASUREMENTS IN TANKS AY-102 AND C-106}

(Excerpted or summarized from Castaing 1995)

The worst-case values from Castaing (1995) were evaluated to determine whether any new information about their validity could be obtained. No further insight into the validity of the numbers reported could be obtained in the time available, but engineering judgment, coupled with recent sampling and speciation results, suggests that these results are to be treated as suspect as a basis for determination of a potential for propagating reaction in nitrate-nitrite-complexant systems.

\section{$\mathrm{AY}-102$}

TOC $=3.82 \mathrm{~mol} / \mathrm{kg}$ (Castaing [1995], Page 7). The other units reported in Castaing (1995) are in $\mu \mathrm{g} / \mathrm{kg}$. Mol $/ \mathrm{kg}$ has not been a unit traditionally used in Hanford Site waste characterization.

Calculation: 3.82 moles (Carbon) $/ \mathrm{kg} \mathrm{x} 12 \mathrm{~g} / \mathrm{mole}=45.85 \mathrm{~g} / \mathrm{kg}$ waste or $0.046 \mathrm{~g} / \mathrm{g}$ of waste or $4.6 \%$ TOC wet basis or $9 \%$ if assumed to be $50 \%$ moisture in sludge

(If the units are reported as grams of carbon, then the actual TOC is $1 / 12$ of the mole \% basis calculated above, or $0.75 \%$ )

\section{A Summary of AY-102 Chemistry}

Scheele et al. (1990) reports on the analysis of four segment core samples taken in the second quarter of FY 1988 from tank AY-102. The bottom three segments were solids and the top segment was a mixture of supernatant fluid and solids. Chemical and physical properties of interest to retrieval were obtained (e.g., shear strength on each segment; density, percent water, percent solids, and percent oxides [pyrolysis at $1050^{\circ} \mathrm{C}$ ] on the core composite; and yield strength and shear stress [1:1 diluted composite]).

Detailed chemical analyses were obtained on the composited samples. The composited solids (data also summarized in Castaing [1995]) had a density of $1.4 \mathrm{~g} / \mathrm{mL}$, contained about $55 \%$ water as weight loss, and had a pH of 9.5. The composited solids are TRU waste having greater than $100 \mathrm{nCi} / \mathrm{g}$ transuranics.

The solid composite was dominated by sodium, aluminum and iron with fluoride, chloride and nitrate as major anions (assay methods do not measure oxyhydroxides, which would have to be estimated). The supernatant fluids contained potassium, sodium and uranium. All anions (nitrate, nitrite) other than phosphate were found in moderate quantities. The TOC (dry weight basis) was $0.83 \%$. 
The supernate is rich in cesium 137, while the solids contained appreciable insoluble cesium (associated with silicate) and a limited amount of strontium 90 .

More recent core samples and grab samples from tank AY-102 have been obtained, as well as samples associated with raising the $\mathrm{pH}$ of the waste to avoid undue corrosion to the tank. When completed, the sampling event results will be incorporated into the tank characterization database.

\section{C-106 - Worst-Case Assay Based Information}

Highest TOC value in liquid $=20,020 \mathrm{mg} / \mathrm{L}$ supernate, maximum density $=1.22$

Calculation: $20,020 \mathrm{mg} / \mathrm{L} \div 1,000=20.020 \mathrm{mg} / \mathrm{mL} \div 1.22 \mathrm{mg} / \mathrm{mL}$ (density) $=$ $16.409 \mathrm{mg} / \mathrm{g}$ (x 100 and $\div 1000$ ) $=1.6 \%$ TOC wet basis or (assume $60 \%$ liquid in supernate - rest is solids). This would result in a dry weight basis of $4.0 \%$ dry weight basis.

\section{C-106 - Average Case Assay Based Information}

Average TOC value in liquid $11,260 \mathrm{mg} / \mathrm{L}$ supernate (Max) $\mathrm{d}=1.22$

Calculation: $11,260 \mathrm{mg} / \mathrm{L} \div 1,000=11.260 \mathrm{mg} / \mathrm{mL} \div 1.22 \mathrm{mg} / \mathrm{mL}$ (density) $=$ $9.230 \mathrm{mg} / \mathrm{g}(\mathrm{x} 100$ and $\div 1,000)=0.9 \%$ TOC wet basis or (assume $60 \%$ liquid in supernate - rest is solids) $\sim 2.3 \%$ dry weight basis.

High TOC value in composited solids $4,620 \mathrm{mg} / \mathrm{l}$ supernate $(\mathrm{Max}) \mathrm{d}=1.4$

Calculation: $4,620 \mathrm{mg} / \mathrm{kg} \div 1,000=4.620 \mathrm{mg} / \mathrm{g}(\mathrm{x} 100$ and $\div 1,000)=0.46 \%$ TOC wet basis or $0.84 \%$ dry weight basis.

The only waste associated with high organics, based on flow sheet analysis, would be the wastes transferred to tank C-106 from B Plant. Only BL wastes should have contained organic complexants. Agnew (1995) estimated $0.12 \mathrm{~mol} / \mathrm{L}$ citrate in the waste, which he associated with the BL waste estimating the TOC concentration to be 1.3 percent maximum as added to the task. However, the B Plant flow sheet indicated that most of the citrate in the waste stream was destroyed by the B Plant evaporator.

If our model of the behavior of complexants in a high-temperature radiation field is accurate, then these conditions should have resulted in low energy waste with the water containing appreciable quantities of sodium oxalate. This insoluble materials would have been diluted during waste compositing, resulting in the low TOC values observed. 
WHC-SD-WM-TI-756, Rev. 0

\section{APPENDIX A.5}

PRESENCE OF 2-ETHYLHEXYL PHOSPHATE RELATED MATERIALS IN OTHER TANKS 
WHC-SD-WM-TI-756, Rev. 0

This page intentionally left blank. 


\section{APPENDIX A.5}

\section{PRESENCE OF 2-ETHYLHEXYL PHOSPHATE-RELATED MATERIALS IN OTHER TANKS}

\section{Preliminary Evaluation of C-103 Samples For Phosphate Esters Related To D2EHP}

Sample C-103 94-02002 X12 (received 1994) was retrieved from storage and a 30-mg aliquot taken of the organic layer present in the sample. This aliquot was dissolved in $2 \mathrm{~mL}$ methylene chloride and treated with an additional $2 \mathrm{~mL}$ diethyl ether that had been previously saturated with hydrochloric acid. This treatment appears to quantitatively transform sodium bis(2-ethylhexyl) phosphate in the sample into the free acid form; as evidenced by copious amounts of white precipitate $(\mathrm{NaCl})$ forming in the vessel. Some precipitation was noted upon addition of acidified ether. The aliquots were then reduced in volume to $100 \mathrm{~mL}$, cooled, and $3 \mathrm{~mL}$ of an uncalibrated solution of ethereal diazomethane added. (Diazomethane is produced by stirring an ethereal slurry of N-methyl-N-nitrosourea over a 40-percent $\mathrm{KOH}$ solution reference (Fieser and Fieser 1967). The esterification is essentially complete immediately; the colored diazomethane is used to visually confirm the presence of excess diazomethane. To ensure complete conversion, the sample was left for one hour in the presence of excess diazomethane before analysis.

Prior GC/MS analysis has tentatively identified other materials related to bis(2-ethylhexyl) phosphate in tank C-106 samples. The mass spectral signature ions (both EI and CI modes) for this group of organic analytes makes identification of these moieties relatively straightforward. We have evidence of the following molecules being present in samples containing D2EHP: butyl bis(2-ethylhexyl) phosphate, tris(2-ethylhexyl) phosphate, and butyl (2-ethylhexyl) phosphate.

GC analysis was done using an HP $5890^{\mathrm{TM}}$ GC (FID) equipped with a low-polarity, thin phase capillary column (HP-5, $30 \mathrm{~m} \times 0.32 \mathrm{~mm} \times 0.25 \mathrm{~mm}$ ). The temperature was ramped from $50^{\circ}$ to $260^{\circ}$ at $8^{\circ} / \mathrm{min}$, and held at $260^{\circ}$ for 5 minutes, affording an adequate separation of the analytes previously observed in tank C-103 floating layer materials.

Inspection of the chromatogram reveals the presence of butyl bis(2-ethylhexyl) phosphate (retention time $24.31 \mathrm{~min}$ ) and tris(2-ethylhexyl) phosphate (retention time $27.13 \mathrm{~min}$ ) only. There does not appear to be an appreciable amount of D2EHP (retention time $22.2 \mathrm{~min}$ ) in this sample. The ratios of these two materials, relative to each other, is similar to that observed in the tank C-106 analysis. The remainder of the chromatogram resembles the results previously reported by Pool and Bean (1994). 
Unfortunately, standard materials are not available for bis(2-ethylhexyl) phosphate (BuD2EHP) or tris(2-ethylhexyl) phosphate (T2EHP) at this time; the response observed for the analyte used for C-106 analysis (D2EHP) was used to calculated these minor components.

The resulting quantitation for these materials (per gram of sample) is as follows:

\begin{tabular}{|c|c|c|}
\hline Conponerit & mog ant & mo Carbontg ani \\
\hline BuD2EHP & 0.003 & 0.0017 \\
\hline T2EHP & 0.0005 & 0.0003 \\
\hline
\end{tabular}

These materials comprise trace components in the mix of TBP and normal paraffinic hydrocarbons found in the C-103 matrix. By comparison, the TBP component has a FID response 50 times as large. In essence, the combination of these two components cannot represent more than 1 percent of the total carbon present in the sample.

It is significant to note the presence of BuD2EHP and T2EHP in these samples in the apparent absence of D2EHP. The presence of butylated species is highly indicative of trans-esterification from TBP or capture of butanol in the sample matrix over the life of the sample. These materials do not appear to be artifacts of sample preparation or analysis. An additional derivatization is warranted to determine if there were some reason for incomplete or inadequate derivatization of this sample.

In the PNNL original analytical scheme, the chemists were tasked with addition of diazomethane to the oil; Dr. Campbell of PNNL recalls a similar result. It is possible that the C-103 aqueous layer may contain D2EHP as the soluble sodium salt; however, this would appear to be unlikely owing to the near absence of D2EHP in the floating layer materials.

If funding permits, the recent samples of sludge from cores of $\mathrm{C}-103$ will be speciated to see whether they contain, by analogy with $\mathrm{C}-106$, appreciable amounts of materials derived from bis(2-ethylhexyl) phosphoric acid. Analytical requirements for speciation of some organics associated with sludge are also being added to the screening DQO, which is undergoing revision. 


\section{DISTRIBUTION}

\section{OFFSTTE}

1 Los Alamos National Laboratory

P.O. Box 1663

Group CST-4 J586.

Los Alamos, NM 87545

S. F. Agnew

ONSITE

4

U.S. Department of Energy - Richland Operations Office

R. G. Harwood

S7-54

D. H. Irby

S7-54

B. L. Nicoll

S7-53

R. Raco

S7-73

7

Pacific Northwest National Laboratory

J. W. Brothers

K9-20

S. A. Bryan

P7-25

J. A. Campbell

P8-08

C. D. Carlson

P7-25

R. T. Hallen

P8-38

G. M. Mong

P8-08

R. D. Scheele

P7-25

31 Westinghouse Hanford Company

H. Babad (6)

S7-14

T. J. Bander

H0-34

D. R. Bratzel

S7-14

R. J. Cash

S7-14

B. A. Crawford

T6-09

J. M. Conner

R2-12

G. T. Dukelow

S7-14

S. J. Eberlein

R2-12

R. A. Esch

T6-06 


\section{DISTRIBUTION (Continued)}

Westinghouse Hanford Company (Cont'd)

J. P. Harris III (3) S2-48

J. O. Honeyman G3-21

J. R. Jewett T6-09

$\begin{array}{ll}\text { J. G. Kristofski } & \text { R2-12 }\end{array}$

J. E. Meacham S7-14

G. A. Meyer $\quad$ S2-48

D. M. Ogden H0-34

$\begin{array}{ll}\text { L. M. Sasaki R2-12 } & \text { R2-12 }\end{array}$

R. D. Schreiber $\quad$ R2-12

L. M. Stock S7-14

L. A. Tusler $\quad$ R2-11

$\begin{array}{ll}\text { T. S. Vail } & \text { R2-52 }\end{array}$

A. E. Waltar H0-32

Central Files $\quad$ A3-88

DPC A3-94 


\begin{tabular}{|c|c|c|c|c|c|c|}
\hline \multicolumn{7}{|c|}{ DISTRIBUTION SHEET } \\
\hline \multirow{2}{*}{$\begin{array}{l}\text { To } \\
\text { Distribution }\end{array}$} & \multirow{2}{*}{\multicolumn{4}{|c|}{$\begin{array}{l}\text { From } \\
\text { Safety Issue Resolution }\end{array}$}} & \multicolumn{2}{|c|}{ Page 1 of 1} \\
\hline & & & & & \multicolumn{2}{|c|}{ Date July 3, 1996} \\
\hline \multicolumn{5}{|c|}{ Project Title/Work Order } & \multicolumn{2}{|c|}{ EDT No. 613756} \\
\hline \multicolumn{5}{|c|}{$\begin{array}{l}\text { Chemical and Chemically Related Considerations Associated With } \\
\text { Sluicing Tank C-106 to Tank AY-102, WHC-SD-WM-TI-756, Rev. } 0\end{array}$} & \multicolumn{2}{|c|}{ ECN No. } \\
\hline \multicolumn{2}{|c|}{ Name } & MSIN & $\begin{array}{c}\text { Text } \\
\text { With All } \\
\text { Attach. }\end{array}$ & Text Only & $\begin{array}{l}\text { Attach./ } \\
\text { Appendix } \\
\text { Only }\end{array}$ & $\begin{array}{l}\text { EDT/ECN } \\
\text { Only }\end{array}$ \\
\hline
\end{tabular}

\section{ONSITE}

DOE-RL

R. G. Harwood

D. H. Irby

B. L. Hicall

R. Raco

$\begin{array}{ll}57-54 & x \\ 57-54 & x \\ 57-54 & x \\ 57-54 & x\end{array}$

Pacific Northwest National Laboratory

J. W. Brothers

S. A. Bryan

J. A. Campbell

C. D. Cartson

R. T. Hallen

G. M. Mong

R. D. Scheele

\section{Westinghouse Hanford Company}
H. Babad
T. J. Bander
D. R. Bratzel
R. J. Cash
B. A. Crawford
J. C. Conner
G. T. Dukel ow
S. J. Eberlein
R. A. Esch
J. P. Harris
J. O. Honeyman
$J$ J. R. Jewett
J. Kristofski
J. E. Meacham
G. A. Meyer
D. M. Ogden
L. M. Sasaki
R. D. Schreiber
L. M. Stock
L. A. Tusler
T. S. Vaíl
A. E. Walter

\section{OFFSITE}

Los Almos National Laboratory

\section{$S$ F AGNEW}

LOS ALAMOS LABORATORY

CST-14 MS-J586

P O BOX 1663

LOS ALAMOS NM 87545
57-14

HO- 34

s7-14

$57-14$

T6-09

A2-25

s7-14

82-12

16-06

$52+48$

G3-21

$76-09$

R2-12

57-14

$52-48$

HO- 35

R2-12

R2- 12

S7-14

R2-11

R2-54

HO- 32 $x$
$x$
$x$
$x$

$x$
$x$
$x$
$x$
$x$
$x$
$x$ 